OVIDIO RIZZO JUNIOR

\title{
CONTROLE SOCIAL EFETIVO DE POLÍTICAS PÚBLICAS
}

TESE DE DOUTORADO

PROFESSOR ORIENTADOR

REGIS FERNANDES DE OLIVEIRA

FACULDADE DE DIREITO DA USP

SÃO PAULO

2009 


\title{
OVIDIO RIZZO JUNIOR
}

\section{CONTROLE SOCIAL EFETIVO DE POLÍTICAS PÚBLICAS}

\author{
Tese de Doutorado apresentada ao \\ Departamento de Direito Econômico e \\ Financeiro como exigência parcial para \\ obtenção do título de Doutor pela \\ Universidade de São Paulo, sob a orientação \\ do Professor Titular de Direito Financeiro \\ Doutor Regis Fernandes de Oliveira.
}

\section{FACULDADE DE DIREITO DA USP \\ SÃO PAULO \\ 2009}


Banca Examinadora:

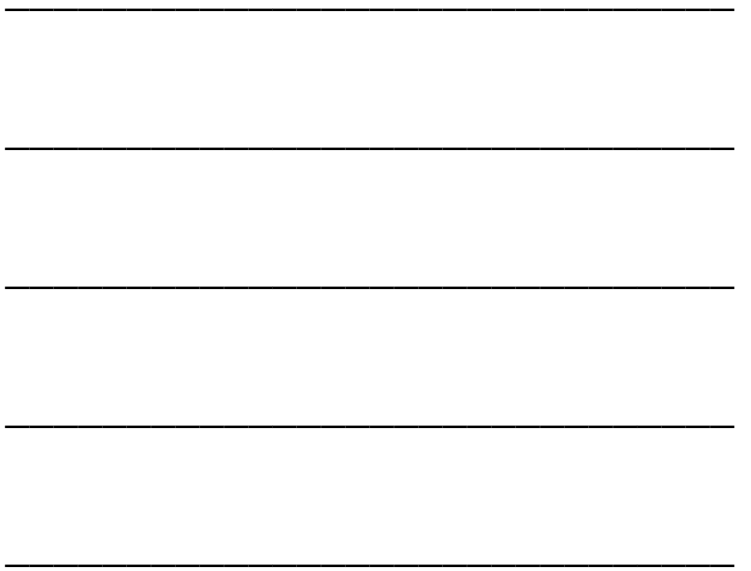


Dedico este trabalho a Ana Maria, luz da minha vida. Ofereço também, com saudades, a meus pais, que sempre nos acompanham. 
Agradeço ao Professor Regis Fernandes de Oliveira, exemplo de correção e amizade, pela paciência na orientação e confiança na oportunidade concedida. 
Agradeço, também, a Regis de Oliveira, Corigliano e Beneti Advogados Associados pelo apoio inestimável, especialmente aos amigos Beth, Rogério, Sidnei, Tutui e Fernando Horta. Ao Professor Dr. Adib Jatene e à Dra. Daniela Kormann, do Hospital do Coração, as minhas homenagens, por tornarem esse sonho possível. 


\section{RESUMO}

São numerosos a produção de textos e os debates centrados na arrecadação de tributos, mas é extremamente pequeno o interesse demonstrado pela nossa doutrina pela forma como é empregada a altíssima carga tributária exigida dos contribuintes. A questão torna-se incompreensível em razão da extrema miséria em que vive 1/5 da população brasileira e do fato de que os órgãos controladores só exercitam a sua competência saneadora depois do dano consumado. Controle prévio, no entanto, não é só aquela participação formal de concordância em relação a certos atos do Poder Público, é o momento em que ocorre a fiscalização do Tribunal, não a obrigatoriedade mecânica exigida para a eficácia do ato.

Esses desacertos ocorrem em razão dos inadequados paradigmas do Direito Administrativo e do Direito Constitucional, que insistem em sobreviver em um Estado moderno, democrático e republicizado. O Direito (material e formal) deveria promover uma ininterrupta interatividade entre o Estado e a sociedade e a formação de uma consciência cívica capaz de impedir a exclusão do cidadão na gestão pública. O controle social proposto encontra seu fundamento último nas imperfeições do sistema democrático representativo e na insegurança jurídica que a judicialização de políticas públicas e uma mais ampla atuação do Tribunal de Contas, capaz de chegar até o trâmite dos tipos orçamentários, poderiam provocar. Assim, o jogo democrático não seria exercido somente na aparência, porquanto democracia e contestabilidade são prismas de uma mesma materialidade.

Em síntese, o estado de exceção permanente em que vivemos, produto de um extremo desequilíbrio entre fato, valor e norma, exige uma imediata mudança no inoperante sistema de checks and balances. O alargamento dos meios de controle, entretanto, só serão seguros se o sistema permitir uma efetiva participação popular no amplo debate que deve ser travado entre todos os atores representativos de uma democracia verdadeiramente deliberativa. O controle social não é a panacéia de todos os males, mas é a única forma de tornar eficaz o complexo conjunto de opções empregadas para o controle interno e externo eficaz de políticas públicas.

Como adverte Bobbio, citado na conclusão do trabalho, “já estamos demasiadamente atrasados (...) Não temos muito tempo a perder".

Palavras-chave: estado de exceção - políticas públicas - controle social - judicialização de políticas - orçamento público. 


\begin{abstract}
The production of texts is wide and the discussions are focused on tax collection but the interest demonstrated by our scholars on the way whereby the very high tax burden charged from taxpayers is used is extremely poor. The issue becomes unintelligible in view of the extreme poverty in which one fifth of the Brazilian population lives and of the fact that the controlling authorities exercise their remedying powers only after the damage is consummated. However, prior control is not only that formal participation consisting in the agreement with certain acts performed by Public Authorities, it is the time when the Court exercises its surveillance, not the mechanical obligatoriness required for effectiveness of the act.

Such mismatching occurs because of the inadequate paradigms of Administrative Law and Constitutional Law, which insist in surviving in a modern and democratic State, and further, a State conformed to the republican system. In opposition, the Law (both material and formal) must promote an interrupted interactivity between the State and society and the creation of a civic awareness, capable of preventing the citizen's exclusion from public management. The social control proposed is ultimately grounded on the imperfections of the representative democratic system and on legal unsafety, which the judicialization of public policies and a wider performance by the Audit Court, capable of reaching the channels of the budget types, could provoke. Thus, the democratic game would not be played only in appearance, since democracy and the exercise of contestation are angles of the same materiality.

In short, the state of permanent exceptionality in which we live, which is the product of an extreme unbalance among fact, value and norm, requires an immediate change in the inoperative checks-and-balances system. However, the enlargement of the control means shall only be safe if the system allows the population's actual participation in the wide discussion that must be conducted among all actors who represent an actual deliberative democracy. Social control is not a remedy for all diseases, but the only form of rendering effective the complex set of options used for the efficiency of internal and external controls of public policies.
\end{abstract}

As warned by Bobbio, quoted in the conclusion of the work, "we are already too late (...). We have not much time to waste".

Keywords: state of exceptionality - public policies - social control - judicialization of policies - public budget. 


\section{RÉSUMÉ}

La production de textes et les débats sont nombreux lorsque le sujet est le recouvrement des impôts mais l'interêt qui suscite ce sujet dans notre doctrine est trop faible vu la très lourde charge fiscale exigé des contribuables. La question devient incompréhensible en raison de l'extrême misérabilité où vit $1 / 5$ de la population brésilienne et du fait que les organes qui sont tenus de faire le contôle n'execent pas leur compétence qu'après le dommage consommé. Contrôle préalable, pourtant, ce n'est pas que la participation formelle du consentement par rapport à certains actes du Pouvoir Public, mais c'est le moment où la fiscalisation de la Cour se réalise et non l'obligatoriété mécanique exigée par l'éficacité de l'acte.

Ces impairs sont dus aux paradigmes inadéquats du Droit Administratif et du Droit Constitutionnel qui insistent survivre dans un État moderne, démocratisé et républicanisé. Bien au contraire, le Droit (matériel et formel) doit promouvoir une interactivité ininterrompue entre l'État et la société et la formation d'une conscience civique capable d'empêcher l'exclusion du citoyen de la gestion publique. Le contrôle social proposé trouve son fondement ultime dans les imperfections du système démocratique répresentatif et dans l'insécurité juridique que la judicialisation des politiques publiques et une action plus large de la Cour de Comptes, capable d'arriver jusqu'au cours des types budgétaires, pourraient provoquer. Ainsi le jeu démocratique ne serait pas exercé seulement dans son apparence, puisque la démocratie et la contestabilité sont des prismes d'une même matérialité.

En synthèse l'état d'exception permanent dans lequel nous vivons, produit d'un désequilibre extrême qui existe entre le fait, la valeur et la norme, exige un changement immédiat dans le système inopérant de checks and balances. Toutefois l'élargissement des moyens de contrôle seront sécurisés seulement si le système permet une participation effective de la population dans un large débat qui doit se réaliser entre tous les acteurs représentatifs d'une démocratie vraiment délibérative. Le contôle social n'est pas la panacée de tous les maux mais la seule manière de rendre l'ensemble complexe des options employées pour le contrôle interne et externe efficace de politiques publiques.

Bobbio nous avertissait «Nous sommes democratiquement en retard $»(.$.$) « Nous$ n'avons pas beaucoup de temps à perdre».

Mots clés: état d'exception - politiques publiques - contrôle social - judicialisation de poltiques - budget publique. 


\section{SUMÁRIO}

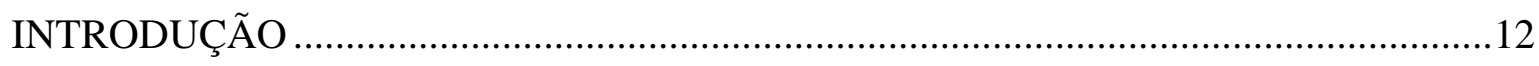

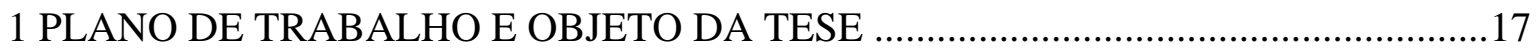

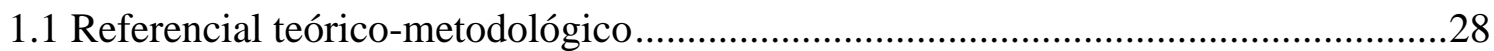

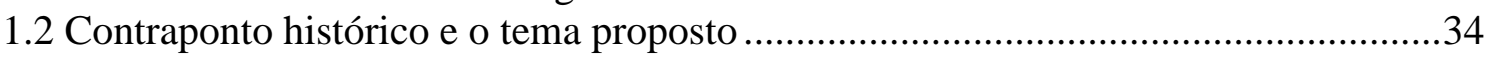

\section{ESTADO CONTEMPORÂNEO E NEOCONSTITUCIONALISMO. PREMISSAS}

PARA A SUA COMPREENSÃO ………………………………………………….....48

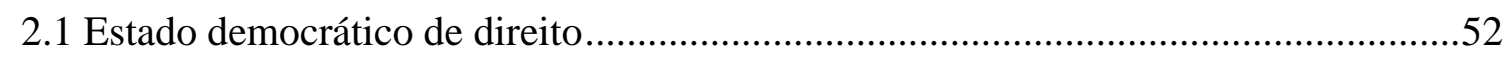

2.2 Estado e sociedade civil. Democracia qualificada e legitimação...............................55

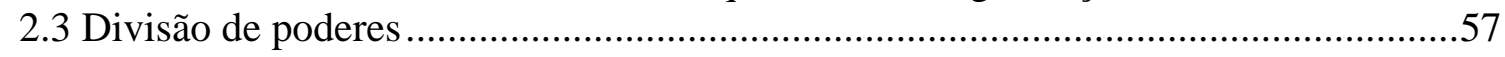

2.4 Administração: o ponto fraco da divisão de poderes ................................................61

2.5 Inadequação do sistema normativo e dos instrumentos de controle

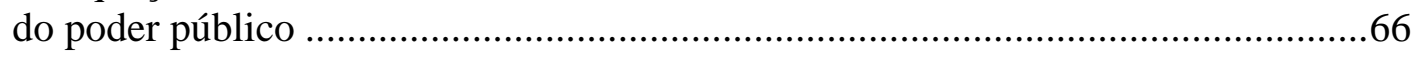

2.6 Hermenêutica constitucional. "Mutação constitucional". Funções de bloqueio,

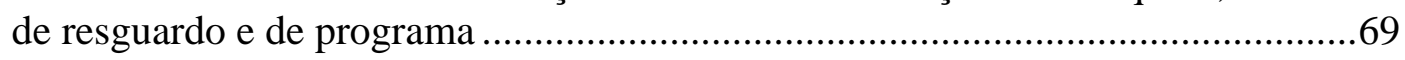

3 ESTADO DE EXCEÇÃO PERMANENTE E POLICENTRISMO DA ECONOMIA

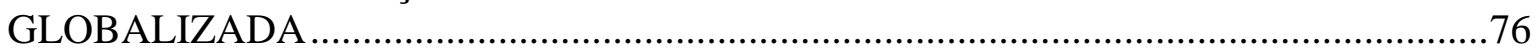

4 AGÊNCIAS REGULADORAS INDEPENDENTES E DEMOCRACIA. DÉFICIT

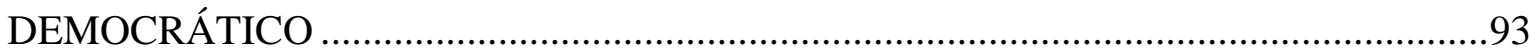

4.1 O poder normativo das agências e o princípio da legalidade.

Delegação de poderes. Atividade regulatória .........................................................96

5 POLÍTICAS PÚBLICAS. CONCEITO JURÍDICO E POLÍTICO .....................................103

5.1 Normas-objetivo, normas programáticas e princípios ............................................104

5.2 Norma como modelo finalístico e o estado dirigente. o paradigma dos direitos

sociais exige prestações positivas do estado. Sanções e controle popular ................106

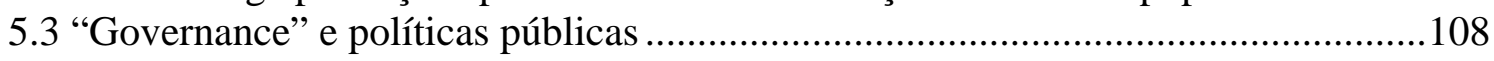

5.4 Controle das políticas públicas. Parâmetros de controle.........................................109

5.5 Princípio da eficiência. Não é um princípio-condição, mas um princípio-fím .........111

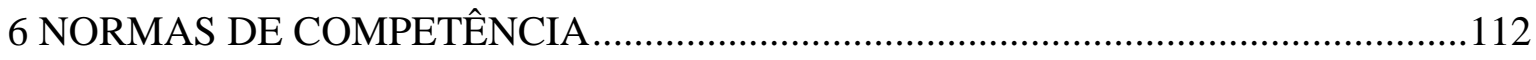

6.1 Interpretação das normas de competência e atribuições do tribunal de

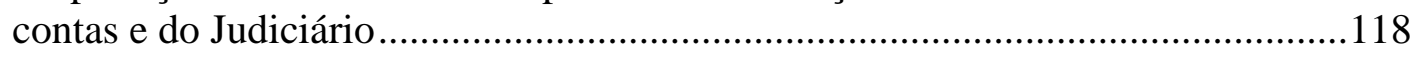

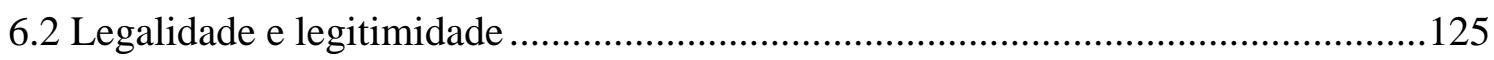

6.3 Competências definidas na Constituição e tribunal de contas. Colisão do

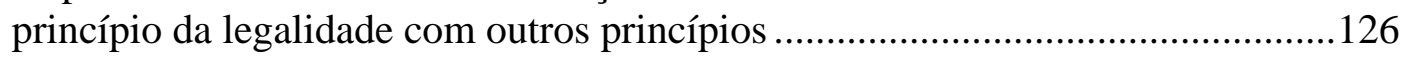

6.4 Como se deve entender o controle da legitimidade exercido pelo tribunal de contas. Pluralismo e controle do poder público

6.5 O direito administrativo brasileiro e o direito constitucional. $\mathrm{O}$ controle social da gestão pública e o tribunal de contas.

6.6 O Tribunal de Contas da União perante o Poder Judiciário, o Poder Legislativo e a titularidade do controle externo. Ele é órgão auxiliar do Poder Legislativo? como se deve entender a autonomia do TCU .... 


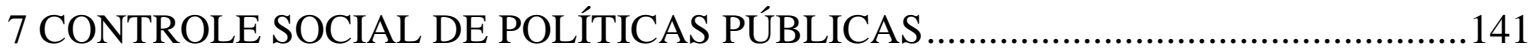

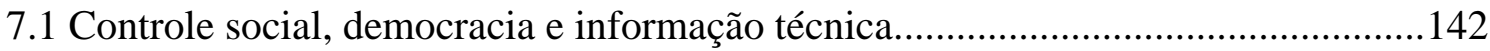

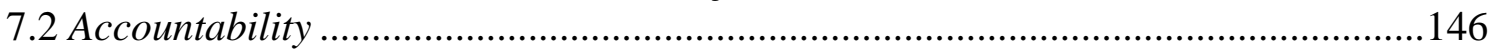

7.3 Controle social de políticas públicas e o Poder Judiciário .......................................149

7.4 Judicialização de políticas públicas e os novos paradigmas internacionais..............155

7.5 Controle social de políticas públicas e legitimação nas ações coletivas ...................160

7.6 Políticas públicas e o tribunal de contas. Poder neutral ............................................165

7.7 Controle social de políticas públicas e o tribunal de contas ....................................166

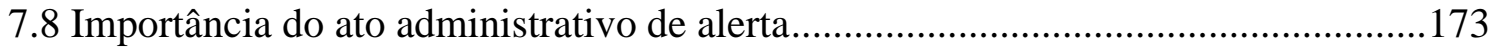

8 ORÇAMENTO PÚBLICO, PARTICIPAÇÃO POPULAR E PAPEL DO TRIBUNAL DE CONTAS NO CONTROLE SOCIAL DE POLÍTICAS PÚBLICAS ......................175

8.1 Democracia inclusiva e responsiva. Contestabilidade e democracia ........................178

8.2 Função política e programática do orçamento público. Lei de natureza híbrida: formal e material. Planejamento estatal e orçamento ..........................................184

8.3 Controle social do orçamento. Representatividade e participação das minorias

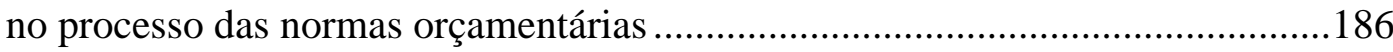

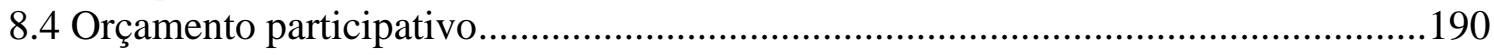

CONCLUSÃO: CONTRIBUTO PARA UM CONTROLE SOCIAL EFICAZ ...............193

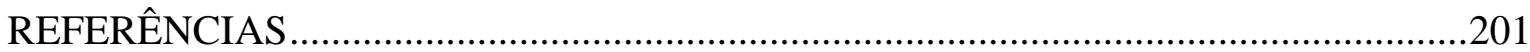




\title{
INTRODUÇÃO
}

\author{
Minhas asas estão prontas para o vôo, \\ Se pudesse, eu retrocederia. \\ Se ficasse no tempo vivo, \\ Eu teria menos sorte. \\ (Gerhard Scholem, Saudação do Anjo)
}

Walter Benjamin, interpretando o "anjo trágico" de Paul Klee, faz as seguintes observações:

Há um quadro de Klee chamado Angelus Novus. Representa um anjo que parece estar a afastar-se de alguma coisa que contempla fixamente. Os olhos estão arregalados, tem a boca aberta e as asas estendidas. É este, seguramente, o aspecto do anjo da história. Ele tem a face voltada para o passado. Onde vemos perante nós uma cadeia de acontecimentos, vê ele uma catástrofe sem fim que incessantemente amontoa ruínas sobre ruínas e lhas vai arremessando aos pés. Ele bem gostaria de ficar, de acordar os mortos e de voltar a unir o que foi destroçado. Mas do paraíso sopra uma tempestade que lhe enfuna as asas e é tão forte que o anjo já não é capaz de as fechar. Esta tempestade arrasta-o irresistivelmente para o futuro, para o qual tem as costas viradas, enquanto o montão de ruínas à sua frente cresce até ao céu. Esta tempestade é aquilo a que chamamos progresso (Benjamin, 1980:697-698). ${ }^{1}$

\section{Boaventura de Souza Santos acrescenta à parábola do Angelus Novus que}

\begin{abstract}
O anjo da história contempla, impotente, a acumulação de ruínas e de sofrimento a seus pés. Gostaria de ficar, de criar raízes na catástrofe para, a partir dela, acordar os mortos e reunir os vencidos, mas sua vontade foi expropriada pela força que o obriga a optar pelo futuro para o qual está de costas. O seu excesso de lucidez combina-se com um défice de eficácia. Aquilo que conhece bem e que
\end{abstract}

\footnotetext{
BENJAMIN, Walter apud SANTOS, Boaventura de Sousa. A gramática do tempo: para uma nova cultura política. 2. ed. São Paulo: Cortez, 2008, p. 53.

O texto original, em inglês, é o seguinte: "There is a painting by Klee called Angelus Novus. It shows an angel who seems about to move away from something he stares at. His eyes are wide, his mouth is open, his wings are spread. This is how the angel of history must look.

His face is turned toward the past. Where a chain of events appears before $u s$, he sees one single catastrophe, which keeps piling wreckage upon wreckage and hurls it at his feet. The angel would like to stay, awaken the dead, and make whole what has been smashed. But a storm is blowing from Paradise and has got caught in his wings; it is so strong that the angel can no longer close them.

This storm drives him irresistibly into the future to which his back is turned, while the pile of debris before him grows toward the sky. What we call progress is this storm".
} 
podia transformar torna-se-lhe estranho e, pelo contrário, entrega-se sem condições àquilo que desconhece. As raízes não o sustentam e as opções são cegas. Assim, o passado é um relato e nunca um recurso, uma força capaz de irromper num momento de perigo em socorro dos vencidos. Isto mesmo diz Benjamin, noutra tese sobre a filosofia da história: "Articular o passado historicamente não significa reconhecê-lo 'como verdadeiramente foi'. Significa apoderarmo-nos de uma memória tal como ela relampeja num momento de perigo" (1980:695). A capacidade de redenção do passado reside nesta possibilidade de emergir inesperadamente num momento de perigo, como fonte de inconformismo. ${ }^{2}$

A imagem formulada por Benjamin é dramática exatamente porque constata a inevitável impossibilidade de o anjo interferir no curso da catastrófica história da humanidade, já que o livre-arbítrio concedido ao homem simplesmente deixaria de existir se o ente celestial pudesse alterar o futuro. Como só ele pode ver nos fatos históricos uma possibilidade de redenção do passado e de alteração do futuro, as pessoas não são capazes de outra coisa além de reconhecer o passado como uma montanha de fatos mortos, destinados a preencher um inútil catálogo de dados arquivados para preservar a história da humanidade.

Em nossa realidade atual, sentimo-nos como o anjo de Klee. Temos a mesma visão aterradora das catástrofes que se amontoam a nossos pés, o mesmo excesso de lucidez de nossas próprias mazelas e o mesmo sentimento de impotência. A catástrofe sem fim que visualizamos em sua verdadeira dimensão é percebida apenas como fatos isolados que justificam sanções tardias e inúteis. A apuração de atos de improbidade e a eventual punição dos culpados dão-nos a falsa impressão de que a punição certa e inexorável é suficiente para compensar as perdas suportadas pelo Estado. No entanto, o alívio que a efetivação da justiça pode proporcionar não é maior que o conforto experimentado por uma mãe que assiste à condenação do assassino de seu filho. A apenação do culpado não lhe devolverá o filho nem aliviará a sua dor, tanto quanto os meios disponíveis no sistema normativo não trarão à sociedade a efetivação de suas justas expectativas, frustradas pela corrupção ou incompetência de seus representantes.

Regis Fernandes de Oliveira ${ }^{3}$ ensina que esse desfecho funciona como um ritual de purificação. A sociedade sente-se satisfeita com a limpeza simbólica operada, canalizando toda a sua indignação para a punição dos culpados. Na visão do psicanalista HorstEberhard Richter, da Universidade de Giessen, em Hessen, na Alemanha, o escândalo que

2 SANTOS, Boaventura de Sousa. A gramática do tempo: para uma nova cultura política. 2. ed. São Paulo: Cortez, 2008, p. 53-54.

3 OLIVEIRA, Regis Fernandes de. Como sair da corrupção? Disponível em: <http://www.cpaperitos.com.br/verartigo.asp?codigo=2005-11-21+6.25.3>. Acesso em: 17 nov. 2008. 
envolveu o ex-chanceler Helmut Kohl e a posterior escolha de novas lideranças funcionaram como o ritual de purificação referido, que se apresenta como uma espécie de expiação de culpa capaz de satisfazer a sociedade e permitir que as coisas tornem a se repetir indefinidamente, desde que de tempos em tempos a democracia possa erigir alguns culpados.

A conclusão óbvia é a de que sanções, por mais eficazes que sejam, não servem senão para satisfazer um conceito de microjustiça incapaz de exceder os estreitos traçados do caso e dos efeitos persuasórios ou intimidativos da pena. Em termos de resgate de direitos fundamentais violados, por absoluta falta de recursos financeiros, as penalidades eventualmente aplicadas aos maus gestores não representam consolo algum para cerca de $42 \%$ da população brasileira, apenas cumprem o inútil papel de purificação simbólica. A veemência da indignidade não necessita maiores considerações, basta confrontar as estatísticas oficiais com a triste paisagem com que deparamos em qualquer rua da cidade. Simples figurante da vida em sociedade, quase metade da população não fala nem reclama, apenas aguarda o momento do descarte final.

O que fazer, então, para liberar o anjo? Reconhecer o passado com precisão histórica, como realmente ocorreu, transporta-nos à época dos fatos evocados, nada mais. São apenas fatos mortos, incapazes de deter o contínuo crescimento de catástrofes e conformar o futuro. Os tempos, na profunda lição de Santo Agostinho, são avaliados nas impressões de nossa consciência presente. As lições desses fatos, arquivadas na mente, são resgatadas no exato instante em que o inconformismo do presente se vale do inconformismo do passado para dar forma à solução que buscamos. Em um momento de perigo, como diz Benjamin, essas impressões são resgatadas em um contexto atual, como fonte de redenção do passado. Eis a lição de Santo Agostinho:

Em ti, ó meu espírito, avalio os tempos! Não queiras atormentar-me os ouvidos
com objeções: é um fato. Não te perturbes com os tumultos das tuas muitas
emoções. Em ti, repito, meço os tempos. Meço a impressão que as coisas gravam
em ti à sua passagem, impressão que permanece, ainda depois de elas terem
passado. Meço-a a ela enquanto é presente, e não àquelas coisas que passaram e
a produziram. É a essa impressão que eu meço, quando meço os tempos.
Portanto, ou estas impressões são os tempos ou eu não meço os tempos.

Pode-se perceber exatamente o que se quer dizer se tomarmos a Guernica como ponto de observação. A tela de Picasso possui vida própria, apartada do sentido original da

4 SANTO AGOSTINHO. Confissões, XI, xxvii, 36. Apud VITA, Luiz Washington. Momentos decisivos do pensamento filosófico. São Paulo: Melhoramentos, 1964, p. 66. 
obra e dos motivos que levaram o pintor a executá-la. A obra, individualmente considerada, também possui um significado universal formado pelas impressões de todo o gênero humano, diferentes das que tinha o autor e diferentes das que têm os observadores. Podemos transportá-la para o nosso tempo ultrapassando a relação com o mundo da guerra civil espanhola, somente para conformar uma específica desconformidade do intérprete. Ela pode ser evocada, nesse sentido, apenas para entender o presente e projetar o futuro que queremos. A mensagem que o quadro transmite, nessas situações de resgate, apresenta-se totalmente abstrata, pronta para ser aplicada à vida concreta do observador individualmente considerado. Exatamente como acontece quando estamos diante de uma situação excepcional, para a qual não temos soluções prontas, e buscamos no passado justificativas capazes de legitimar procedimentos novos, que, embora não sejam iguais, possuem acentuada semelhança.

Bobbio tem a mesma visão de resgate do passado no contexto concreto do presente: “A história tem apenas o sentido que nós, em cada ocasião concreta, de acordo com a oportunidade, com nossos desejos e nossas esperanças, atribuímos a ela". 5

Como será possível aprender com o passado e alterar o futuro desastroso que nos aguarda? Existe alguma solução viável para liberar o anjo da história para redimir o nosso passado? O que deve ser feito para desacelerar o insano amontoado de tragédias que quase sepultam o gênero humano? A questão, é fácil perceber, escapa notavelmente da normalidade das coisas e das cauções normativas, que não foram editadas para situações excepcionais. Como assevera Marx, o homem é o mundo do homem, por isso, os seus humanos anseios não estão vinculados a argumentos de pura lógica, nem se conformam com promessas mirabolantes. Verdade, justiça e dignidade não são expectativas para um futuro incerto e indeterminado, vaga "moral provisória" que dispensa embasamento de vida e raízes profundas - são valores imediatamente exigíveis. O centro do Estado não é o homem abstrato, simples peça do coletivo, mas o ser humano individualizado, com suas fraquezas e necessidades atuais. É essa participação cidadã que a democracia moderna reclama; que nós reclamamos.

As normas editadas pelo Poder Legislativo, desde as Leis Orçamentárias, não podem ostentar legitimidade somente observando o devido processo legal, já que a pluralidade de atores no controle da execução de políticas públicas também pressupõe a plena democratização das etapas em que são tomadas as decisões que provocam o

5 BOBBIO, Norberto. A era dos direitos. Disponível em: <http://www.scribd.com/doc/4874590/A-ERADOS-DIREITOS-NORBERTO-BOBBIO>, p. 29. Acesso em: 19 dez. 2008. 
nascimento das políticas. Esse espaço de mútuas participações, no entanto, não deve ser conformado com grupos de ativistas políticos chamados para representar uma sociedade plural, ao contrário, depende da confiança que os atores participantes do controle social possuem entre si e da prévia informação confiável transmitida ao cidadão. A nossa proposta é exatamente esta: o Judiciário e o Tribunal de Contas provocam a participação popular em todas as fases de formulação e implantação de políticas públicas. 


\section{PLANO DE TRABALHO E OBJETO DA TESE}

A tese está estruturada em nove partes, a começar por este capítulo delimitador do trabalho. Como a inadequação do sistema normativo decorre do estado permanente de exceção em que vivemos, é indispensável começar fixando o Direito atual e seu contraponto histórico. Nesse confronto de recíprocas influências, a crise anunciada desde a elaboração do projeto de qualificação será exaustivamente delineada, uma vez que esse overview é vital para buscar a solução ideal para tentar conter o fantástico desperdício de reservas públicas.

Em razão das drásticas alterações por que passaram o Estado, o Direito Administrativo e todo o Direito Público, procura-se, no Capítulo 2, fixar as significativas mudanças ocorridas no cenário geral e no palco onde se desenrolam as competências atribuídas a Poderes independentes, mas harmônicos entre si. Assim, esclarecemos, de início, que os pressupostos de fato e as prognoses do constituinte que justificaram a distribuição de competências sofreram profunda alteração após a edição da Constituição de 1988, tendo em vista que o próprio Estado evoluiu a partir de 1990. Em conseqüência de importantes alterações econômicas e sociais ocorridas em todos os países, especialmente decorrentes da globalização e do progresso da informática, o Direito e a política sofreram, nos últimos 20 anos, a maior alteração ocorrida em toda a história da humanidade.

O Estado de hoje não é o mesmo do fim dos anos 80 do século que findou. $\mathrm{O}$ Direito não é mais o mesmo, nem a sociedade, a vida e o homem são os mesmos. O constitucionalismo também está profundamente alterado. $O$ texto da Constituição, entretanto, não sofreu alteração substancial, apesar das 57 Emendas agregadas ao seu corpo, assim como todo o Direito positivado não sofreu significativas alterações estruturais. Enfim, embora uma verdadeira revolução social e econômica esteja acontecendo, como fazer reformas em velhas estruturas com métodos não atualizados? Se em 1990 falava-se em sistemas normativos paralelos e até em Constituição paralela, imagine-se agora, que a crise econômica obriga o Estado a editar normas ad hoc para 
atender casos altamente técnicos. José Eduardo Faria afirma, com muita propriedade, que "quanto maior é sua produção normativa nessa linha, mais seu Direito Positivo perde organicidade e racionalidade sistêmica, dada sua pretensão de abarcar uma intrincada e por vezes contraditória pluralidade de interesses e comportamentos altamente particularísticos". 6

Os organismos internacionais de crédito possuem sobre os devedores inegável ingerência na administração e na governança de Estados que ostentam, agora, soberanias apenas compartilhadas. Como acreditar, então, que a economia interna de um país em desenvolvimento, extremamente sujeito às pressões da economia mundial, esteja entregue a órgãos governamentais que só podem fazer o que está previamente admitido em lei formal? Como explicar que a vida e o Direito mudaram, mas as regras do jogo devem continuar a ser entendidas com os mesmos recursos hermenêuticos com que avaliávamos o Direito Privado? Como admitir que complexas políticas públicas sejam julgadas como atos administrativos isolados? Como aceitar que um Direito criado para hipóteses que nem de longe se aproximam dos deveres próprios de um Estado Democrático de Direito de nossos dias continue a ser aplicado sem a necessária adequação?

Nesse segundo capítulo precisamos todos esses fatos, delineamos a situação atual, como em um instantâneo tirado para confirmar a gravidade da situação, e preparamos a sequiência das abordagens que serão feitas nos capítulos seguintes, até a conclusão final do trabalho, que deixará estabelecido não se poder mais ver o Poder Judiciário esgotar os limites de suas possibilidades em uma inútil tentativa de controlar gestões cada vez mais fraudulentas, nem o Tribunal de Contas somente como mero auditor de contas dos entes públicos, em sua função de esquartejar o corpo já sem vida dos anseios e necessidades mais fundamentais do ser humano.

O corpo de delito, representado pelos seus vestígios internos e externos, pode ser visto nas manchetes dos jornais, nas crises políticas ocasionadas por grupos interessados em abafar a repercussão pública de uma corrupção generalizada, no imobilismo do Parlamento, que tem sua atenção totalmente voltada para a interminável sucessão de escândalos políticos, na troca de verbas por apoio político, na violência feita ao orçamento para manutenção do poder, na miséria, na morte desassistida e na impressionante comprovação de que a quantia de $\mathrm{R} \$ 234$ bilhões atirados ao lixo seria suficiente para

6 FARIA, José Eduardo. Declaração Universal dos Direitos Humanos: um cinqüentenário à luz da globalização econômica. Instituto de Estudos Avançados da Universidade de São Paulo, v. 11, n. 30, São Paulo, maio/ago. 1997. Disponível em: <http://www.scielo.br/scielo.php?script=sci_arttext\&pid=S010340141997000200004\&lng=en\&nrm=iso\&tlng=en>. Acesso em: 14 nov. 2008. 
retomarmos o caminho da dignidade e do pleno emprego. A vítima, no caso, somos todos nós, mas impossível não dar a ênfase necessária aos desvalidos, aos que, literalmente, morrem de fome, enquanto esperamos a ação do constituinte derivado e do legislador para nos salvar. Pode-se lembrar, a propósito, Camus, na obra A peste, ao descrever como as pessoas, em total abstração, tentam levar uma vida normal enquanto a morte vai ceifando os seus vizinhos mais próximos. A mesma abstração parece nos entorpecer, a todos, na espera de um mal que sabemos estar a nossa volta, mas que afastamos de nossos pensamentos para suportar o convívio com o pesadelo. Diante desse quadro, Rousseau certamente teria de rever alguns sentimentos que acreditava presentes até nos animais irracionais. Apesar do triste reconhecimento de que tudo é perfeito na criação divina, mas degenera nas mãos dos homens, imagine-se a decepção daquele que sustentou ser inerente ao homem a compaixão pelos seus semelhantes: o homem "sente uma repugnância inata ao ver sofrer a um semelhante", sentimento esse experimentado até pelas bestas, as quais julgava serem capazes de se sensibilizar na presença do sofrimento. ${ }^{7}$ Com esse pano de fundo, a divisão de poderes do Estado e a Administração Pública, seu ponto fraco de repartição, também serão abordadas, assim como a democracia qualificada e a inadequação dos instrumentos de controle previstos no sistema normativo.

O Capítulo 3 trata de uma realidade inafastável: o estado de exceção em que vivemos e o policentrismo da economia globalizada. Destaque especial é dado ao estado de guerra permanente em que vivem os Estados Unidos e aos reflexos jurídicos e econômicos que esse estado de exceção provoca no mercado e no mundo globalizado.

O quarto capítulo tem o foco direcionado para as agências reguladoras, a regulação estatal e os limites do poder normativo que a elas é atribuído por lei. Tratamos da autonomia das agências, dos sérios atritos que essa independência produz em relação ao governo, e do controle possível, em face das normas vigentes. Lembramos fato recente, que teve como protagonistas os dirigentes da ANAC, o Presidente da República e o Ministro da Defesa nomeado para solucionar a crise da aviação.

O quinto capítulo é inteiramente dedicado às políticas públicas e ao controle possível dos programas de governo, a cargo do Judiciário e dos Tribunais de Contas. Nesse capítulo, os prismas em evidência são a dimensão jurídica das políticas públicas, o Estado Democrático de Direito e os direitos humanos, o papel desempenhado pelos Tribunais de

7 ROUSSEAU, Jean Jacques. Discurso sobre a origem dos fundamentos da desigualdade entre os homens. São Paulo: Escala, 2006, v. 7, (Coleção Grandes Obras do Pensamento Universal), p. 49. 
Contas para permitir a participação da sociedade na formulação e execução desses programas, bem como os parâmetros de controle.

Nessa senda, no Capítulo 6 analisamos a distribuição de competências e a posição dos Tribunais de Contas, como órgãos constitucionalmente autônomos, vocacionados para controlar a legalidade e a legitimidade dos atos de entes públicos, bem como para exercer pleno controle na gestão de recursos públicos. Avaliamos, também, as suas competências mais polêmicas e a natureza jurídica de suas decisões, tendo em vista o poder jurisdicional exclusivo atribuído ao Poder Judiciário. Por outro lado, procuramos demonstrar o poder normativo que lhe foi atribuído pela Constituição e a maneira como a Corte de Contas pode, efetivamente, auxiliar a sociedade a participar da reabilitação do ideal democrático de governo do povo e pelo povo. Este é outro tema bastante controvertido, em que procuramos defender uma posição francamente contrária ao entendimento majoritário da doutrina.

No Capítulo 7 a abordagem é feita para focalizar o tema do controle social de políticas, que representa o cerne desta tese. Por sua importância, será dado destaque à informação técnica capaz de efetivamente proporcionar um controle social eficaz. Em seguida, tratamos do controle social possibilitado pelo Poder Judiciário e pelo Tribunal de Contas.

O oitavo capítulo enfrenta um tema que certamente irá gerar polêmica: o papel do Tribunal de Contas no controle de políticas públicas desde o seu berço: as leis orçamentárias.

O Capítulo 9 é conclusivo. Nele procuramos conciliar todos os pontos analisados no corpo do trabalho, de modo a justificar a solução apresentada como a única viável, independentemente da complexa atualização de nosso sistema normativo e sem qualquer desconsideração ao princípio da legalidade e à separação de poderes.

Anota-se, apenas, para finalizar o capítulo, que optamos por enfrentar alguns poucos pontos polêmicos com alguma profundidade em vez de repetir análises tópicas que não representam nenhuma contribuição científica para o Direito. Nessa senda, procuraremos compreender, explicar e demonstrar por que determinadas competências do Tribunal de Contas e do Judiciário não precisam ser extraídas, literalmente, da regra de Direito, e qual a amplitude dessas competências, principalmente depois das mudanças ocorridas no Estado do século XXI.

Para delimitar o alcance da tese, ressaltamos que este não é um trabalho que versa, especificamente, sobre tribunais de contas. É uma tese que tem em foco a viabilidade de 
um controle eficaz e, principalmente, seguro de políticas públicas, de molde a garantir um melhor aproveitamento de escassos recursos públicos. O que se pretende assentar é que o único controle realmente seguro é aquele que traz para o debate a imprensa e a sociedade, mas não sob o inútil foco, tradicionalmente utilizado, da retórica titularidade da soberania do povo, em nome do qual todo o poder é exercido. O mérito da política e todas as fases de seu ciclo, aí incluindo o trâmite das leis orçamentárias, devem ser expostos à sociedade como um todo, porquanto o sistema democrático fundado na representação popular só não se apresenta mais imperfeito que a representação direta da sociedade feita por intermédio de grupelhos de indivíduos politicamente manipuláveis.

O controle de políticas referido é o social, feito por uma pluralidade de atores, sob a provocação do Tribunal de Contas da União, órgão institucionalmente legitimado para conferir a forma como os recursos públicos são empregados, e, dentro de suas naturais limitações, também sob a provocação do Judiciário.

Assim, ainda que o tema central da tese não seja exatamente o Tribunal de Contas, é inegável que um controle social realmente eficaz e seguro só pode ser alcançado por seu intermédio. Ele é a entidade neutra e independente naturalmente vocacionada para filtrar e avaliar as informações necessárias para estimular a sociedade a opinar sobre o destino das riquezas que lhe são exigidas.

Em uma democracia, os recursos públicos não devem ser simplesmente exigidos dos contribuintes sem o seu contínuo, legítimo e eficaz acompanhamento em todas as fases que compõem a arrecadação e o gasto desses valores, aí incluindo os planos e projetos que irão determinar o conteúdo dos tipos orçamentários. Isso só se consegue se a implantação de políticas tributárias for legitimada pela prévia oportunidade oferecida à sociedade de manifestar-se sobre a forma como estão sendo investidos os valores que lhe são exigidos. O aperfeiçoamento da cidadania permite que o jogo democrático não seja exercitado somente na aparência, já que os processos preestabelecidos de representação democrática não conferem legitimidade aos representantes do povo, porquanto há uma enorme diferença entre Congresso e povo reunido.

Nesse sentido, à objeção de que o povo não está apto a discutir suas preferências com seus representantes recordamos que "cidadãos não caem do céu", conforme alerta Wolfgang Kersting, titular de Filosofia da Universidade de Kiel, "e uma sociedade liberal não deveria relegar a formação de uma cidadania liberal ao acaso". 8

8 KERSTING, Wolfgang. Democracia e educação política. In: MERLE, Jean-Christophe; MOREIRA, Luiz (Org.). Direito e legitimidade. São Paulo: Landy, 2003, p. 113. 
Para o desenvolvimento do trabalho, como é evidente, não nos interessa a verificação de atos administrativos, mas a correção e fiscalização de programas de governo e de Estado. Desse modo, faremos abstração de controles que já foram fartamente desenvolvidos pela doutrina para centrarmos nossa atenção não no ato isolado, mas no complexo conjunto de atos que compõem uma gestão democrática nitidamente prospectiva. Esse tipo de controle, como se pode pressentir e será mais bem demonstrado no desenvolvimento da tese, não é alvo nem do controle interno exercido pela Administração nem do controle exercido pelo Judiciário, uma vez que esse último tem sido chamado com maior freqüência para o controle de atos administrativos determinados, próprios de microeconomia. Se o juiz emite conceitos de legalidade, e não de mérito, torna-se extremamente difícil sindicar, na via judicial, políticas públicas de uma maneira abstrata, desvinculada da ameaça de dano concreto ou de dano iminente, que legitimam todos aqueles que ocupam o pólo ativo de uma relação processual. É um controle, portanto, não repressivo, que deve ser dirigido a opções políticas que, na data do controle, ainda não se mostram claramente equivocadas.

O equívoco referido reside no próprio objetivo da política. A correção de rumo é indicada para corrigir as diretrizes de um programa que não é nem ilegal nem inconstitucional. Poder-se-ia dizer que ele, por não atender a expectativa constitucional, deve ser sopesado e reanalisado, embora não encerre qualquer inconstitucionalidade. Esse vício talvez se consume no futuro se as alterações sugeridas não forem consideradas e as prognoses do controlador se confirmarem. Pelo simples fato de se mostrar, aparentemente, contrário à Constituição, deve a Administração, sob pena de responsabilidade de seus executores, proceder a estudos mais aprofundados sobre a matéria questionada e analisar as razões colocadas pelo controlador. Em outras palavras, o que se pretende é a adoção do melhor critério possível para a obrigatória adoção do princípio da eficiência, tomado em seu sentido meramente potencial, de aptidão que o programa tem de gerar os efeitos esperados.

São evidentes, portanto, as dificuldades que devem ser superadas para alcançar o alvo pretendido neste trabalho, pois tanto as políticas públicas como os órgãos que as executam, como as agências reguladoras, suscitam intensa controvérsia. Acrescentando-se a isso a inadequação do Direito Positivo para absorver o complexo poder normativo que as agências possuem e a etérea substância que molda a extrema plasticidade das políticas, obtemos a grandeza dos obstáculos que se opõem à tarefa proposta. 
Nos meios jurídicos, por exemplo, é visível o desconforto para precisar o alcance das competências atribuídas pela Constituição à Corte de Contas, especialmente em relação a algumas ações que vêm sendo tomadas para determinar a órgãos da Administração a prática de condutas positivas em matérias que, aparentemente, seriam de exclusiva atribuição dos órgãos governamentais.

Trazendo a questão para o nível concreto dos fatos da vida, indaga-se se o poder de avaliar a legitimidade dos atos de entes públicos justificaria, por exemplo, a livre permissão para inadmitir os critérios utilizados pelo Ministério de Minas e Energia para o enquadramento dos consumidores da subclasse baixa renda nos benefícios da tarifa social de energia. O Tribunal teria poderes para considerar inadequada a forma como o Ministério implantou a política de universalização de energia elétrica? Como seria possível explicar a determinação feita ao governo para aprofundar os estudos relacionados ao consumo domiciliar de energia, com vistas a beneficiar a população de baixa renda? O critério de classificar, automaticamente, como consumidor de baixa renda todos os domicílios com consumo de até $80 \mathrm{kWh}$ não é exclusivo da Administração? O sistema normativo vigente justificaria a intromissão do Tribunal de Contas para avaliar e reprovar a maneira como a implantação da universalização de energia elétrica estava sendo conduzida? Note-se que a sindicância foi feita exatamente considerando os critérios utilizados pelo Ministério, no entender do Tribunal, insuficientes para determinar se todos os alcançados pelo benefício deveriam realmente merecer a concessão de tarifa subsidiada. Se esse é, tradicionalmente, o sítio irrecusável para o Executivo emitir conceitos de conveniência e oportunidade, por que então o Tribunal de Contas sentiu-se competente para corrigir o rumo dessa política?

A dificuldade para justificar a ação do Tribunal, em casos semelhantes ao relatado, e que são trazidos a contexto apenas para ilustrar a polêmica discussão acerca de suas competências, está em saber qual o núcleo de sua sindicância, pois, se não resta dúvida de que atos e normas contrários a uma determinada política pública podem ser por ele contrastados, a sua atuação não se mostra tão visível quando se trata de controlar a própria atividade resultante desses atos e normas. Mais do que isso, a inércia governamental para estabelecer uma política poderia justificar a interferência do Tribunal? Se a resposta for positiva, teremos que a sua interferência poderá provocar, em alguns casos, o estabelecimento de uma política pública não prevista - pelo menos não nessa extensão nem pelo governo, nem pelo Legislativo.

As correções de rumo determinadas pela Corte podem até não ter sido desejadas por aqueles que detêm o poder de iniciativa na implantação de programas governamentais. 
Mesmo assim, essas alterações não poderiam ser desconsideradas pelo governo? Qual a natureza jurídica dessa determinação?

Essa última hipótese, ligada à vontade livre e consciente do Poder Público de não efetuar alterações substanciais em políticas públicas que, por sua dimensão, poderiam caracterizar não a correção de uma política já existente, mas um novo programa, ocorreu com a atuação da Corte de Contas no episódio da recente crise por que passou o setor aéreo, especialmente no que diz respeito às condições operacionais dos equipamentos de radar e de controle de aproximação nos aeroportos de grande movimento, e ao perfil do quadro de servidores da Empresa Brasileira de Infra-estrutura Aeroportuária (INFRAERO) e da Agência Nacional de Aviação Civil (ANAC) pelo prisma da remuneração e qualificação profissional.

No Acórdão n. 2.420/2006, o Tribunal de Contas da União efetuou diversas Recomendações e Determinações para que se buscasse esclarecer os cortes efetuados nas propostas orçamentárias elaboradas pelo DECEA/COMAER, o contingenciamento de recursos, a retenção indevida de receitas tarifárias pela INFRAERO, a fonte insuficiente para investimentos em modernização e expansão do controle do tráfego aéreo brasileiro, a insuficiência de recursos humanos na atividade de controle do tráfego e a falta de articulação entre os diversos órgãos governamentais.

Como extrair do texto constitucional a natureza jurídica das Determinações feitas ao Ministério da Defesa, ao Ministério do Planejamento e à Casa Civil da Presidência da República para a realização urgente de estudos objetivando avaliar a conveniência da criação de carreira específica de controladores de vôo, e não alterar, com esse alerta, a competência exclusiva do Poder Executivo de avaliar a necessidade de criação de cargos indispensáveis à Administração? Note-se que a determinação não encerra um juízo instrumental de ineficiência do serviço público para obter uma determinada prestação concreta, mas principal, com vistas a alcançar a segurança e normalização do tráfego aéreo como um todo. Melhor dizendo, a intervenção do Tribunal foi emitida sobre um juízo de ineficiência genérico, cujas causas são desconhecidas, e que, após os estudos determinados, podem até não se confirmar. Perceba-se que o Tribunal de Contas da União determina procedimentos diante, apenas, de suspeitas sobre uma possível falha no serviço, em razão de uma também possível inexistência de pessoal qualificado para o controle de vôo. Apesar da quase total falta de parâmetros concretos para avaliar a suspeita de ineficiência, o Tribunal, investido em uma competência pouco explicada, julga indispensável aprofundar os estudos para confirmar a conveniência de se propor a criação 
da carreira de controlador de vôo. O que justifica esse alargado exercício de suas atribuições? O Judiciário também poderia assumir um papel relevante nessa equação?

A essa altura já é possível, mesmo com as rápidas pinceladas que delinearam o problema real apresentado, sentir que a competência do Tribunal de Contas não está delimitada por ações mecânicas do mal consumado, inúteis para preveni-lo, a exemplo do legista, que somente analisa e explica as origens e conseqüências do dano consumado em relação ao corpo necropsiado. Desse prisma, sua competência é quase exclusiva, posto que não se poderia esperar do Legislativo, por inaptidão técnica, senão os rumos abstratos de uma política. Quanto ao controle judicial, mesmo com a inevitável aceitação da judicialização das políticas, é inegável que a jurisdição civil continua ligada a um sistema procedimental erroneamente vocacionado para a solução de litígios individuais, o que dificulta sobremaneira o controle judicial dos atos do governo de um modo exclusivamente abstrato, apartado dos interesses individuais de pessoas ou grupos sociais. Mesmo assim, as novas técnicas de controle social provocado pela atuação do Judiciário são plenamente aplicáveis no Brasil.

Será dada ênfase, também, guardados os limites do trabalho, para a defesa de interesses coletivos e difusos, porquanto o sistema implantado, embora tenha inovado positivamente o modelo de litigância, não evita uma persistente sub-representação junto aos órgãos judiciais do Estado. A legitimidade para a defesa desses interesses continua a ser restrita, e isso afasta a maior parte da população do debate político subjacente às políticas.

Pretende-se demonstrar que o Tribunal de Contas, exatamente por seus conhecimentos técnicos sobre a contabilidade estatal, pode promover, desde o início do trâmite das leis orçamentárias, a inclusão da sociedade no debate que dará destino aos tributos arrecadados. A referência feita ao trabalho do legista prende-se ao controle tardio do Tribunal de Contas sobre atos que provocaram danos consumados e questiona se o orgulho comumente expresso em relação à bela Constituição de 1988 conforma-se com a crua realidade dos fatos da vida. Como enfatizou Celso Antônio Bandeira de Mello, se um ser extraterrestre se dispusesse a estudar os seres humanos que viviam no Brasil, pelo prisma de seu estatuto fundamental, chegaria à admirável conclusão de que esse povo havia atingido os píncaros do desenvolvimento, tal era o elevado programa constitucional dedicado à ordem econômica e social. O jurista referia-se à Constituição de 1969, que em seu art. 153, § 14, assegurava o respeito à integridade física e moral do detento e do 
presidiário, e aos horrores que, apesar da prescrição, ocorreram nas masmorras da ditadura militar.

Se esse mesmo viajante de outro planeta voltasse em 2008 e observasse a Constituição vigente, ficaria extasiado com os elevados propósitos que norteiam a nossa civilização, revelados pelos nobres fundamentos que inspiram a construção de uma sociedade livre, justa e solidária, um desenvolvimento nacional construído sobre a erradicação da pobreza e a redução das desigualdades sociais, porventura existentes, e a promoção do bem de todos, sem qualquer concessão a preconceitos e discriminações indesejáveis. Verificaria também, apesar da perfeição de seu pacto político, que esse povo não se cansa de lapidar a obra construída, emendando-a 57 vezes em apenas 20 anos, tudo para garantir a qualquer trabalhador, por menos qualificado que seja, um salário mínimo capaz de atender às necessidades básicas de moradia, alimentação, educação, saúde, lazer, vestuário, higiene, transporte e previdência social, bem como reajustes periódicos capazes de lhe preservar, indiscutivelmente, o poder aquisitivo. Por isso, com a ênfase dada à determinação de que ninguém será submetido a tortura nem a tratamento desumano ou degradante, jamais acreditaria se lhe contassem que uma jovem, menor, fora encarcerada com mais de 20 espécimes do sexo masculino proscritos da vida em comunidade. ${ }^{9}$

De fato, reina entre nós um inacreditável consenso sobre a perfeição do sistema normativo que garante a democracia em nosso país. Eleições periódicas livres, poderes independentes e harmônicos entre si, bem como um ordenamento formado por uma quantidade exorbitante de dispositivos legais que se ajuntam a uma Constituição emoldurada por belíssimos enunciados, completando-a, fornecem a falsa impressão de que, de lege ferenda, quase nada há a fazer. Exatamente por isso poderíamos até acreditar que somos capazes de instituir políticas públicas e confiar a sua execução a autarquias especiais, independentes do poder centralizado no governo, com a maior segurança, sem qualquer ajuste nas estruturas carcomidas de um Direito Administrativo cunhado no Direito francês do século XIX.

Essas autarquias, conhecidas como agências reguladoras autônomas, em razão da autonomia de que desfrutam, não podem ser alcançadas, em muitos casos, nem pelo Presidente da República, nem pelo Judiciário, que não se dispõe a investigar o mérito de seus atos, nem pelo Tribunal de Contas, que, apesar de estar vocacionado para o controle da legitimidade dos atos da Administração, deve, na opinião de muitos, aguardar a

9 O Estado de S. Paulo, Caderno Cidades/Geral, 8 dez. 2007. 
consumação dos danos provocados para apreciar as contas dos gestores que levam, irreversivelmente, o País à bancarrota. Releva-se, a propósito, que a explosiva crise econômica de 2008, depois de longa incubação, não fez mais do que apressar a elevação das tragédias que se avolumam a nossos pés.

A maioria das pessoas concorda que seria muito perigoso alargar a competência do Órgão de Contas para uma pronta reação, capaz de evitar ou minorar a consumação do mal. Em nome da segurança jurídica e de uma ortodoxa visão do princípio da legalidade, mesmo conhecendo a inadequação de nosso Direito para tratar os complexos problemas que o Direito Público atual apresenta, preferem a violência cometida contra a nação à realista admissão de que é inevitável adaptar as normas de Direito Positivo, já existentes, à realidade excepcional dos fatos da vida. Não se quer negar com isso a urgência de medidas que devem ser tomadas pelo Congresso Nacional para diminuir o hiato existente entre Constituição formal e Constituição real, no entanto parece imprescindível acelerar o passo para tornar minimamente eficaz o controle sobre os gastos públicos e estancar a sangria desatada de nossas reservas, independentemente da ação legislativa. Com as crises econômicas da atualidade, a questão se torna, com certeza, muito mais dramática.

Enquanto isso não acontece, o Tribunal de Contas continua a ser considerado mero auxiliar do Poder Legislativo, sem poderes nem competência para influir positivamente nos programas de governo, ou para impedir o desfalque diário que a corrupção e a ineficiência impõem aos cofres públicos. Tudo por não se poder afrontar o dogma da impossibilidade de a Corte de Contas exercer algum tipo de controle prévio sobre os atos de órgãos públicos. Há uma aura negativa em torno dessa Casa, que a afasta de missões verdadeiramente importantes, mantendo-a nos afazeres diários da verificação de contas públicas surradas e aposentadorias. Não que essas questões não sejam importantes, mas afastá-la de controles vitais para o País somente por causa de uma interpretação ultrapassada das competências que lhe são direcionadas na Constituição parece ser irrisão verdadeiramente suicida.

Por outro lado, o Poder Judiciário também reluta em assumir uma postura mais efetiva no controle de políticas de Estado e de governo. Diante desse quadro, porção significativa de nossa Constituição passou a possuir, pelo reconhecido desajuste de parte de nosso sistema de Direito Positivo com a realidade da vida, normas de gritante ineficácia. Com a inadequação, ou convivemos com sistemas paralelos, inclusive com uma 
Constituição paralela, como bem observou Gordillo, ${ }^{10}$ ou caminhamos para o abismo sem fim em que nos lançamos, enquanto resignadamente aguardamos a ação legislativa atualizadora de um Direito que não pode ser mais o mesmo.

Há uma terceira opção, que é justamente o cerne de nosso trabalho: um controle com densidade suficiente para provocar o ingresso da sociedade na elaboração e no controle dos programas públicos. Essa participação, no entanto, não pode continuar a ser a demagógica invocação da soberania popular, nem a posição de supremacia que, abstrata e vagamente, os cidadãos possuem sobre os mandatários eleitos. Eis, em síntese, o motivo e fundamento último da tese: não há segurança em se reconhecer a existência de um estado de emergência permanente sem a mediação da sociedade considerada como um todo.

Sem esse respaldo, normas garantidoras de direitos humanos e princípios positivados da maior significação são removidos para uma espécie de limbo constitucional, no qual permanecem ao lado das normas cuja impositividade aguarda a edição de providências supervenientes que nunca são tomadas. A única diferença entre elas é que as normas programáticas tradicionais quase nunca chegam, na prática, a ser mais que meras recomendações para o legislador infraconstitucional, já que normas de exceção impedem a sua efetivação, como a cláusula do financeiramente possível e o risco abstrato de que o deferimento da medida pleiteada possa provocar uma avalanche de ações iguais, ao passo que as que se tornaram inadequadas pela evolução do Direito moderno impedem a plena eficácia de direitos fundamentais inalienáveis. Elas não podem mais ser utilizadas com o sentido original, pois os pressupostos de fato que determinaram a sua edição não são mais os mesmos.

\subsection{REFERENCIAL TEÓRICO-METODOLÓGICO}

A metodologia empregada nesta tese só pode ser compreendida se relevarmos de antemão que não há conceito jurídico consolidado para políticas públicas, que esses programas são mutáveis até a sua completa conclusão e que eles não refletem uma realidade existente, porquanto pretendem, justamente, alcançar uma realidade apenas desejada.

Lembramos, então, que o Direito atendia razoavelmente aos critérios positivistas kelsenianos, mas apresentava-se "completamente impérvio àquilo que é a necessidade do

10 GORDILLO, Agustin. La administración paralela. Buenos Aires: Civitas, 1982. 
homem, que é de viver no mundo de valores e realizá-los". Diogo de Figueiredo complementa esta lição afirmando que

\begin{abstract}
o positivismo instilou-nos a crença, própria do racionalismo novecentista, de que a Ciência era um espelho do real, e que, em conseqüência, o Direito, tampouco, poderia passar de um conhecimento empírico, depurado de desejos, de aspirações e de valores, pois de outro modo ele não seria "científico". (...) Este é o motivo pelo qual, de modo similar ao que vem ocorrendo nos demais ramos do Conhecimento, volta a predominar uma visão gnoseológica, mas revestida de modéstia epistemológica mais acentuada, que considera que a validade das proposições científicas é sempre provisória, e, por isso, flexibilizam-se, modificam-se, transmutam-se e atualizam-se constantemente, em função do tempo e de suas circunstâncias aplicativas. ${ }^{11}$
\end{abstract}

A observação é procedente, ainda porque o positivismo de Kelsen não se limita ao conceito exclusivamente normativo de sua Teoria Pura. Na segunda fase de seu pensamento o mestre já aceitava como válida uma construção hipotética para o fundamento último do Direito. O terceiro Kelsen, completando uma evolução em seu pensamento, a nosso sentir, inacabada, mas suficiente para antever novos desdobramentos, passou a aceitar não uma hipótese, mas algo como uma norma conjetural. Miguel Reale, a respeito, adverte que o jurista, em sua obra póstuma, "ao tratar das normas jurídicas e das normas morais, (...) admite a possibilidade de uma complementação entre a Moral e o Direito". ${ }^{2}$ Não se pode dizer, portanto, que o positivismo de Kelsen corresponda a um entendimento que foi, posteriormente, revisto pelo próprio autor.

A tensa situação política nos Estados Unidos, a partir da guerra fria e dos confrontos que desequilibravam alternadamente o sistema bipolar flexível, completou a revolução dos fatos que Kelsen chegou a vivenciar no período que viveu em Berkeley, e foi determinante para a sua mudança de posição em relação ao pensamento problemático, tão bem exposto por Kant. O terceiro Kelsen não negava que conhecer é diferente de pensar, ou melhor, de conjeturar.

Ora, se o notável jurista presenciasse a complexa relação socioeconômica do mundo globalizado de 2008, certamente chegaria a uma posição próxima à da lição de Diogo de Figueiredo, no sentido de que "a própria realidade também é constituída por esses desejos, aspirações e valores, que os sublimam, captados nos princípios jurídicos, de modo que, mesmo sem que o percebamos, constituem a razão e o sentido das relações

11 MOREIRA NETO, Diogo de Figueiredo. Mutações do direito público. Rio de Janeiro: Renovar, 2006, p. 110-111.

12 REALE, Miguel. Nova fase do direito moderno. São Paulo: Saraiva, 1990, p. 206-207. 
humanas e, assim, são elementos do próprio Direito". ${ }^{13}$ Em conseqüência, o Direito passou a ser uma representação de nós mesmos, da maneira como nós subjetivamente a percebemos, com nossas aspirações e valores.

Sucede que isso não basta para dar forma jurídica a certos projetos políticos que demandam uma constante e complexa coordenação de vários programas de Estado e de governo. Muitos deles são herdados de legislaturas e governos passados, mas concorrem, em igualdade de condições, com os novos programas que continuam a ser, ininterruptamente, implantados. Já não é mais do querer que se fala, já que a necessidade, o volume reduzido de recursos públicos, além de vontades políticas partidárias completamente opostas, são os pilares da estrutura jurídica erigida para transformar uma realidade que precisa ser, urgentemente, mudada.

A realidade que procuramos obter são sonhos que, racionalmente, podem ser considerados exeqüíveis. Essa racionalidade, no entanto, apresenta-se extremamente vaga. Pode-se lembrar, sem qualquer conotação política, o exemplo típico de sonho desvestido de racionalidade que determinou a implantação, em São Paulo, a partir de 1979, de um oneroso projeto destinado a encontrar petróleo na bacia do rio Paraná. A questão complicase quando lembramos que as utopias, mesmo racionais, talvez não cheguem a justificar a álea do investimento de parcos recursos públicos. O que se deve, então, entender por utopia? Sabemos que não é a realidade das coisas que determinam as políticas públicas, já que é justamente uma utopia reveladora de realidades com as quais não concordamos que permite a formação de todo um conjunto de microssistemas jurídicos destinados a transformar o sonho em realidade. Como reconhecer a colisão entre a quimera e a justa expectativa de uma vida melhor, possível de alcançar? Acaso não é verdade que, se as jazidas de petróleo fossem descobertas, teria sido difícil reconhecer a extensão do risco assumido pelo governo estadual?

A dúvida justifica-se se trouxermos a questão da Paulipetro para um plano hipoteticamente atual: se o plano paulista de auto-suficiência em petróleo fosse levado aos tribunais para averiguação de sua racionalidade, qual deveria ser a decisão?

Por mais relevante e indispensável que seja a utopia, somos forçados a admitir que a essência das políticas públicas está constituída pela mais fluida e evanescente matéria: o desejo de alcançar uma situação que pode ser pensada, tem chance de ser efetivada, mas não existe senão na esperança de alcançá-la. A desconformidade, em última análise, dirige-

13 MOREIRA NETO, Diogo de Figueiredo. Mutações do direito público, p. 111. 
se contra uma realidade que só pode ser modificada com o auxílio de métodos nada objetivos, quase sempre extraídos de meros indícios captados pela sensibilidade do gestor da política. Como é óbvio, esses diálogos sensíveis entre realidades mutantes, necessidades públicas e direito só acontecem durante a implantação das políticas, já que as fases em que são formuladas apenas espelham cortes limitados da realidade da vida e de seus possíveis desdobramentos.

Não sendo possível prever com antecedência todas as variáveis, a obra que sai das mãos do legislador só começa a adquirir movimento - vida, enfim - durante a sua execução. Assim, políticas públicas são implantadas por meio de formas jurídicas não permanentes, sempre dependentes de cláusulas de ajustamentos com a realidade e com as perspectivas que podem ser extraídas das oscilações que acompanham a economia, a política e as necessidades sociais.

O Direito brasileiro, conforme ensinamento do Prof. Adilson Dallari, foi estruturado sobre fundamentos nitidamente retrospectivos, já que as normas jurídicas são conformadas

pela força dos fatos, após a ocorrência de situações que evidenciam a existência de lacuna a ser preenchida. São extremamente raros os exemplos de produção normativa determinada por uma visão prospectiva, a partir de modelos ideais para disciplinar futuros acontecimentos prováveis, de maneira a assegurar, antecipadamente, a composição de eventuais conflitos e a satisfação do interesse público. ${ }^{14}$

Assim, um conceito correto de políticas públicas dificilmente pode ser formulado, porquanto elas são a expressão de elementos não-jurídicos, como fatos econômicos, políticos e sociais. Conceitos socioeconômicos e de administração pública constituem a massa de moldar das políticas. Nesse tema, o jurídico resume-se à forma como esses dados extrajurídicos são pinçados do mar de necessidades públicas, de molde a movimentar a máquina estatal em sua contínua tarefa de prestações positivas.

Maria Paula Dallari Bucci, uma das mais influentes especialistas na matéria, ensina que

a melhor contribuição que pode ser dada por um trabalho de sistematização conceitual de políticas públicas é fornecer um conjunto de referências aos Poderes Executivo e Legislativo na elaboração dos veículos jurídicos das políticas públicas. (...) é plausível considerar que não haja um conceito jurídico de políticas públicas. Há apenas um conceito de que se servem os juristas (e os não juristas) como guia para o entendimento de políticas públicas e o trabalho

14 DALlARI, Adilson Abreu. Emancipação do Direito Público no Brasil. Revista Eletrônica sobre a Reforma do Estado, Salvador, n. 5, mar./abr./maio, 2006. Disponível na Internet: <http://www.direitodoestado.com.br>. Acesso em: 05 out. 2008. 
nesse campo. Não há propriamente um conceito jurídico, uma vez que as categorias que estruturam o conceito são próprias ou da política ou da administração pública.

Entretanto, se não há um conceito jurídico, deve haver, com certeza, uma metodologia jurídica. ${ }^{15}$

O que se está querendo dizer é que, se ainda não há um conceito jurídico de políticas públicas, embora deva haver uma metodologia jurídica para analisá-las, não há como negar que elas não podem ser medidas pelos métodos jurídicos tradicionais. Não se pode reduzi-las a nenhum instituto conhecido. Se admitirmos que elas são semelhantes às normas-objetivo, ainda que muito mais complexas, poderemos ter uma leve percepção de como é preciso construir o subsistema de direito a partir do Direito Positivo, mas ele (o subsistema) precisa ser reconstruído a cada nova política e a cada alteração havida no panorama socioeconômico.

Os conceitos que informarão a metodologia de implantação e controle de políticas escapam notavelmente do campo jurídico, porquanto às ciências sociais, à economia e ao mercado compete fixar as necessidades e os problemas que devem ser regulados, ao depois, pelo Direito. Desse modo, a natureza jurídica das políticas ainda está para ser determinada, uma vez que os elementos que as compõem são variáveis a ponto de tornar extremamente dificultoso reconhecer a sua verdadeira expressão ontológica. ${ }^{16}$

Peter Häberle, falando em Lisboa sobre os novos desafios do constitucionalismo, manifestou a sua dificuldade, mesmo sendo um constitucionalista alemão, em fazer uma reflexão metodológica sobre o tema, porque a tarefa revelava a necessidade de criar uma certa medida de Eros pedagógico, pleno de otimismo científico e de utopia:

Deve acrescer-se a contemplação do elemento de utopia, que necessariamente
sempre acompanha o porvir e o crescimento de um estado constitucional.
Também $L$. Locke, pai do estado constitucional, foi então uma utopia, também a
Europa foi utopia à época dos pais fundadores, a criação do federalismo nos
EUA foi, também, inicialmente utopia. (...) Trata-se da utopia concreta, do
princípio esperança, que possibilidade ao homem o proceder correto e o torna
um ser cultural. ${ }^{17}$

Como ponto de partida, está o fato de a figura do jurista que guia seu trabalho por uma metodologia jurídica ser comumente representada por alguém cuja ocupação não

15 BUCCI, Maria Paula Dallari. O conceito de política pública em direito. In: BUCCI, Maria Paula Dallari (Coord.). Políticas públicas: reflexões sobre o conceito jurídico. São Paulo, 2006, p. 46-47.

16 SIMÃO, José Fernando Simão. A natureza jurídica da arbitragem. In: GUILHERME, Luiz Fernando do Vale de Almeida (Coord.). Novos rumos da arbitragem no Brasil. São Paulo: Fiuza Editores, 2004, p. 225.

17 HÄBERLE, Peter. Novos horizontes e desafios do constitucionalismo. RDE Revista de Direito do Estado. Rio de Janeiro, Renovar, n. 6, abr.jun. 2007, p. 80. 
suscita desejos e otimismos de qualquer espécie. Manifestá-los, costuma-se dizer, seria pouco científico. Sucede que, tal como na lição de Häberle, as políticas públicas também estão assentadas sobre o princípio da esperança, do desejo de transformar o próprio Estado. Da mesma forma, são impulsionadas por razões nada jurídicas: realidades não admissíveis em um Estado Democrático de Direito. A fome, a doença, a ignorância, a indignidade da pessoa humana, as crises socioeconômicas, enfim, são os cortes metodológicos que precisam ser feitos. Os cortes, por assim dizer, jurídicos das políticas são variáveis, já que não se pode, ainda, classificá-las como uma categoria jurídica.

$\mathrm{O}$ modelo de Estado que temos e o que queremos ligam-se apenas por desejos e ambições que só adquirem densidade durante a implantação dos programas. Pode acontecer, inclusive, que isto nunca venha a acontecer. Que metodologia jurídica então deve ser empregada para entender os programas políticos?

Ora, os cortes metodológicos devem ser o retrato de situações de fato que continuamente se transformam. Qualquer ilação jurídica só poder ser extraída da análise e dos prognósticos de fatos passados, presentes e futuros. Por isso, diferentemente da análise ordinariamente incidente sobre ações regulares da Administração, os cortes metodológicos devem ser feitos não sobre instantâneos congelados, mas sobre retratos, abertos que estão a novas interpretações e novas influências externas.

Alfonso García Figueroa ensina, nesse sentido, que

Cuando contemplamos una instantánea de alguien, apenas adquirimos una
comprensión superficial de la persona. Cuando contemplamos un retrato,
particularmente un retrato pintado por un buen artista, entonces accedemos a
una rica pluralidad de sensaciones que nos hablan no sólo de un cuerpo humano,
sino de toda una vida y de una personalidad. Además, cabría añadir que el
retrato está abierto a las nuevas interpretaciones que puedan hacer los diversos
estudiosos (historiadores, historiadores del arte, psicólogos) del futuro y en esa
medida el retrato incorpora un cierto dinamismo.
(...)
Yo creo que la teoría del Derecho debería aspirar a elaborar retratos y no
instantáneos más o menos nítidas. ${ }^{18}$

Essa é a razão pela qual nos ocuparemos tão longamente dos fatos que compõem o contraponto histórico do tema de controle de políticas públicas. O princípio esperança, referido por Häberle, explica bem o porquê da metodologia não usual que comanda este trabalho. Em alguns momentos, como quando desenvolvemos o estado de exceção permanente em que vivemos e os desejos e emoções que comandam as políticas públicas,

18 FIGUEROA, Alfonso García. Réplica al Profesor Thomas da Rosa Bustamante. RDE Revista de Direito do Estado, Rio de Janeiro, Renovar, n. 8, out./dez. 2007, p. 148. 
torna-se difícil distinguir a identidade de ponto e contraponto, já que parecem, alternadamente, intercambiáveis. Pode-se dizer que eles não mais subsistem independentemente, pois há somente processo de estruturação, onde diferença e repetição se sobrepõem a identidade e repetição. O movimento em que deve ser analisado o tema principal, que é o controle social de políticas públicas, faz com que as identidades esmaeçam em sua significação singular e cedam lugar ao resultado da complexa reunião das partes que o compõem.

Em vista dessas dificuldades a tese procura, na medida do possível, preservar a sua coerência lógica e manter um processo de desenvolvimento atento ao diálogo interativo que a singularidade da base deve manter com a riqueza do contraponto.

\subsection{CONTRAPONTO HISTÓRICO E O TEMA PROPOSTO}

Tercio Sampaio Ferraz ensina que na ocorrência de um fato excepcionalmente grave, que não se ajusta ao modelo legal previamente estabelecido, é lícito suspender o padrão de legalidade vigente e substituí-lo, temporariamente, por um padrão de efetividade capaz de preservar, no auge das adversidades, as exigências básicas do ser humano e do Estado. Essa válvula de escape, também conhecida como regra de calibração, pressupõe que a suspensão do padrão de legalidade seja passageira e que a normalização da situação restaure o padrão ordinário dos tempos estáveis. Estes são os efeitos buscados: um combate eficaz às graves e excepcionais anormalidades, que não podem ser controladas por medidas ortodoxas, e o mais breve retorno à normalidade e às garantias preestabelecidas caracterizadoras do Estado de Direito.

Mas o que acontece se a situação excepcional perdurar até se tornar, ela própria, regra ordinária? Uma regra de calibração de efeitos permanentes, exatamente por suspender o padrão de legalidade, certamente perderá a legitimidade inicial e tornará o sistema arbitrário e ditatorial. As coisas, entretanto, não são tão simples como costumavam ser, nem o Direito tão certo e arrumado como se mostrava até o final do século passado. As sucessivas crises econômicas, de âmbito mundial, e políticas, de fundo predominantemente ético; a crônica insuficiência de recursos públicos; o descalabro das aposentadorias miseráveis, a indignidade da assistência social e previdenciária e a completa ineficiência do Estado são algumas das mazelas permanentes mais significativas. De tão corriqueiras, não mais nos comovem nem revoltam, a ponto de não reconhecermos que, em verdade, há muito vivemos em um estado de exceção permanente. 
Torna-se difícil, portanto, admitir que o chamado "estado de exceção permanente" possa ser resolvido por uma norma de calibração ou justificar a suspensão permanente de normas de Direito Positivo. A questão assume relevância em face das dificuldades econômicas atuais, visto que, se as previsões dos experts estiverem corretas, levaremos alguns anos para sair do crash de 2008. Os excluídos da sociedade, que hoje são totalmente ignorados, verão suas fileiras notavelmente engrossadas em razão das novas bolhas que, a exemplo da dívida imobiliária norte-americana, ameaçam surgir na forma de inúmeras crises pop-up de menor gravidade. Entre nós, o exemplo típico dessas bolhas que ameaçam estourar é a especulação feita com vendas de opções de compras, nas quais o investidor assume uma taxa futura para a venda de dólares e recebe a rentabilidade dos juros que aufere em razão da estabilidade da moeda. A soma de todas essas especulações, dirigidas a problemas que podem ser considerados subprimes tupiniquins, exatamente por causa da sua expressiva quantidade, possui o danoso efeito de tornar as crises permanentes, assim como um vírus que escapa a qualquer combate por sua incessante mutação. Em síntese, é forçoso reconhecer que, embora não se possa equiparar a gravidade de uma única crise, a de 1930, com a dos acontecimentos de 2008, a devastadora ocorrência de inúmeros desajustes e choques econômicos, que passam a existir endemicamente na economia, assume relevância bastante semelhante.

Confirmando esse temor, de predição da crise endêmica e de seus inevitáveis desdobramentos, transcrevemos diversas notícias publicadas em jornais de grande circulação para marcar a flagrância de fatos recentes que não podem deixar de integrar o Direito nem de comandar a real efetividade de direitos e garantias constitucionais, arduamente sedimentados na evolução humana. Se o Direito é, conjuntamente, fato, valor e norma, a vida real, palpitante, merece assumir o seu peso apropriado na avaliação dos elementos de sua tridimensionalidade. Seria ingenuidade imaginar que a vida, em seus momentos excepcionais, não fosse considerada na grandiosidade de sua extrema mutabilidade. As três variáveis da equação, portanto, não se excluem mutuamente nem são subestimadas ou valorizadas além da realidade da vida que temos e que almejamos ter.

Com esse propósito, trazemos um editorial da GlobalEurope Antecipation Bulletin, publicado em 19/08/2007, que, a exemplo de grande parte dos especialistas europeus, já anunciava o potencial da crise que visivelmente se aproximava. Eis o texto que delatava, com hora marcada, o esperado crash:

Crise das subprimes:

Após o setor financeiro, a próxima vítima será o US dólar.

Por GEAB - GlobalEurope Antecipation Bulletin 
Ao contrário do que dizem hoje estes peritos que ontem negavam toda possibilidade de crise financeira associada às "subprimes", o dólar estadounidense será a próxima vítima da reavaliação das taxas de câmbio que nos espera.

Assim, ao contrário das análises da maior parte das mídias financeiras nestes dias, não é na zona Euro que o Banco Central Europeu (BCE) injeta agora estas enormes quantidades de liquidez e sim no sistema bancário internacional através dos grandes bancos europeus que também são operadores financeiros internacionais. Estes "euros" na realidade são, no essencial, transformados em US dólares e encaminhados para os Estados Unidos, o ator central da crise global de liquidez. Ao fazer isto, o BCE ajuda a Reserva Federal americana permitindolhe injetar menos liquidez (impedindo assim um pânico mais forte na Wall Street, de onde provém o essencial das dificuldades). E, no curto prazo, gerando uma diminuição temporária da taxa de câmbio Euro/USD, o que permite ao BCE desembaraçar-se das pressões políticas internas contra o Euro forte.

Mas as perspectivas econômicas para os Estados Unidos no $2^{\circ}$ semestre tornamse sombrias (na medida em que os rendimentos bursáteis constituíam o último sustentáculo para o consumo americano - ver GEAB N. 9 e a Info Décryptée de 5 de Junho, Economia EUA: a transfusão do Fed e da Wall Street que mascara a entrada em recessão - confirmando as antecipações do LEAP/E2020 - como começam a indicar certos números da Reserva de Filadélfia, assim como o afundamento contínuo do setor americano da construção), ao passo que a zona Euro não experimentará senão um enfraquecimento (ver GEAB N. 16).

Quando assentar a "poeira" do atual afundamento dos mercados financeiros, os operadores perceberão que a economia dos EUA veio abaixo enquanto a zona Euro permitiu limitar os desgastes. A Ásia, por sua vez, estará numa posição muito delicada devido principalmente às conseqüências da crise financeira sobre as exportações e as moedas, enquanto o dólar retomará o caminho da sua espiral descendente.

19/Agosto/2007 ${ }^{19}$

A previsão feita em agosto de 2007 não foi produto de futurologia, nem pessimismo, ao contrário, era aguardada por todos. Apesar disso e da constatação de que em agosto de 2007 a crise financeira já se encontrava instalada, comportamo-nos como a cigarra da fábula que exalta a previdência laboriosa da formiga. No Brasil, com extrema admiração, espantamo-nos com a correção da política econômica do governo e fizemos a mais completa abstração do motivo determinante do ingresso do capital estrangeiro em nossa embevecida economia: as bolhas dos países capitalistas, que determinaram o generoso investimento no Brasil, eram constituídas de créditos podres.

É claro que fizemos bem em tirar proveito dessa insanidade, no entanto, o minimamente razoável seria ter tomado medidas suficientes para não embarcar irresponsavelmente no trem da alegre ilusão que enublou a cautela de investidores, políticos e autoridades. Ao contrário, continuamos a utilizar o dinheiro público como moeda de negociação política e a repartir os recursos públicos em troca de apoio político. O orçamento público continuou, sem qualquer alteração, a ser manipulado como se as

19 Crise des subprimes: Après le secteur financier, la prochaine victime est le dollar US. Disponível em: $<$ http://www.leap2020.eu/Crise-des-subprimes-Apres-le-secteur-financier,-la-prochaine-victime-est-ledollar-US_a857.html>. Acesso em: 5 nov. 2008. 
entradas fossem inesgotáveis. Em vez de poupar, como a formiga, tomamos a enxurrada de capitais estrangeiros como sinal de excelência gerencial.

O que estamos assistindo, desde então, é digno de Mefistófeles. Nunca foi tão oportuno lembrar a obra de Goethe e o diálogo de Mefisto com o imperador como depois que se conheceu o interior do sistema financeiro da maior potência da Terra, erigido sobre fundações de aparente solidez, mas que se revelaram tão ilusórias quanto os tesouros do imperador. Não obstante essa economia exercer influência direta na economia de todos os países do mundo e apesar das fortes suspeitas de que esse castelo estava erigido em solo movediço, aceitamos de boa mente participar do jogo ilusório da economia sem a instituição de salvaguardas necessárias ao enfrentamento de uma eventual crise mais séria. Como vimos, é inapropriada a utilização do adjetivo eventual, porquanto esse vocábulo deve qualificar aquilo que é contingente, incerto, que é produzido por fato casual, acidental, não uma crise prevista com tanta antecedência.

Em sua obra, Goethe relata que, cansado das promessas do diabo e da insuportável situação de penúria por que passava o seu reino, o imperador cobrou uma ação mais efetiva de seu diabólico interlocutor. O diabo respondeu-lhe que poderia conseguir tudo o que era pedido, acrescentando que seria fácil, embora o fácil seja difícil. Ele então propôs que fossem utilizados os magníficos tesouros enterrados sob as terras do imperador. Às portas da falência, o monarca esforçava-se para crer na promessa do diabo: tesouros, que tesouros? Pouco tempo depois, seus administradores trouxeram-lhe a notícia de que o império estava salvo e de que o povo festejava nas ruas a súbita prosperidade. Mostraramlhe, então, uma simples folha de papel, a primeira deste tipo, em que se lia:

\footnotetext{
Para o conhecimento de quem deseje: esta nota vale mil coroas. Como seguro penhor, garante-a um sem-número de bens enterrados nas terras do imperador. Já se tomaram as cautelas a fim de que o rico tesouro, logo que desenterrado, se ponha em seu lugar.
}

Desde então, pela noite afora, ininterruptamente, puseram-se a preparar milhares de notas semelhantes, de todos os valores, para felicidade geral. O Mestre da sedução inspirou o ganancioso imperador a empreender uma tarefa com pouquíssimos riscos: enganar o povo com uma mentira na qual todos estavam dispostos a acreditar. $\mathrm{O}$ que todos queriam, até mesmo o imperador, era que o artifício lhes trouxesse benefícios imediatos e duradouros. Enquanto todos acreditassem no engodo, a farsa estaria absolutamente segura. 
Bastava não discutir a essência da garantia, representada pelos inexistentes tesouros enterrados.

O ouro, lastro histórico da economia, havia sido substituído por uma oportuna folha de papel, assinada pelo imperador e, no decorrer da história, por ministros de Estado, presidentes de bancos centrais, banqueiros e, finalmente, por qualquer pessoa com competência para representar uma empresa de capital aberto. Até mesmo o ouro é negociado contabilmente, em operações presentes e futuras. A ficção, nesse particular, supera com vantagens a realidade. Os bens corpóreos mais valiosos, ao lado de fantásticos patrimônios abstratos, compõem os balanços de empresas que têm capital intangível muitas vezes superior ao patrimônio físico. A empresa Microsoft, por exemplo, havia pouco tempo demonstrava um "Patrimônio Líquido Contábil" de US\$ 11 bilhões, mas o seu valor no mercado chegou a US\$ 500 bilhões, conforme cotações da Morgan Stanley, entidade nos Estados Unidos que acompanha o valor de mercado das maiores empresas do mundo. A diferença de US\$ 489 bilhões, que está sendo denominada "Capital Intelectual", referese a esses recursos da Microsoft, o que certamente representa um problema para a ciência da contabilidade, que ainda não conseguiu mensurá-los de forma segura, e para a economia global e o Direito, que não sabe como regular a circulação de riquezas que não podem ser medidas senão subjetivamente.

Tercio Sampaio Ferraz, comentando o relato fantástico de Goethe, compara esses papéis sem lastro a

\begin{abstract}
um espectro de riqueza, falso como os tesouros que Mefisto faz imaginar sob o solo do império. Sob o signo do papel-moeda, nasce assim a economia moderna, que se torna o lugar das aparências, um jogo diabólico nas mãos dos financistas, dos aplicadores em bolsa, dos investidores, destes fantásticos herdeiros de Mefistófeles, o senhor das ilusões. ${ }^{20}$
\end{abstract}

Sucede que essa questão não se limita mais aos domínios da economia e daqueles que estão diretamente envolvidos no mercado financeiro, hoje ela também atinge quem nunca esteve disposto a participar do jogo. A álea é suportada, talvez com maior intensidade, por pequenos empresários, trabalhadores e donas de casa, que não têm como absorver os impactos da falta de crédito e da recessão produzidas pela crise. Estamos falando também de cortes profundos em exíguos investimentos direcionados a áreas essenciais, como a educação e a saúde, e do inadmissível desrespeito aos direitos

20 FERRAZ JR., Tercio Sampaio. Prefácio da obra Curso de economia: introdução ao direito econômico, de Fábio Nusdeo. Disponível em: <http://www.terciosampaioferrazjr.com.br/?q=/publicacoescientificas/121>. Acesso em: 6 nov. 2008. 
fundamentais do homem e do cidadão. Se o controle de gastos públicos - especialmente dos valores destinados à execução de políticas públicas - sempre foi essencial, exatamente pela forma como têm sido dissipados, após os acontecimentos de outubro de 2008, a urgência assumiu proporções dramáticas.

O controle que propomos é um controle eficaz, que se estenda até as origens das políticas públicas: as leis orçamentárias. Pretendemos demonstrar que esse controle pode ser feito pelo Judiciário, com uma postura mais atual, conforme tem sido experimentado, com sucesso, em alguns países, e pelo Tribunal de Contas, único órgão capacitado para possibilitar o debate que deve ser travado diante da sociedade.

No projeto que preparamos para o exame de qualificação já alertávamos para a possibilidade de uma nova crise financeira, tão grave quanto a que ocorreu após o crash da Bolsa de Nova York em 1929. Questionamos, então, caso isso viesse a acontecer, se seria possível continuar a utilizar cegamente parâmetros objetivos de regulação e controle que decorrem da divisão de poderes e competências literalmente expressas em nosso sistema normativo. Essa análise continuaria a dispensar qualquer tipo de consideração razoável acerca da evidência de que convivemos diariamente com situações excepcionais e de que a norma positivada é instituída para a normalidade da vida econômica e social? Não estaríamos, sem o saber, assistindo à morte do paradigma sociocultural dominante e ao nascimento do paradigma que lhe há de suceder, produto do contraponto histórico da era que já desestabilizou o pós-moderno? Infelizmente, a crise já tem um esboço bem delineado e a previsão de seus possíveis desdobramentos é sombria. A Europa e os Estados Unidos acreditam que uma recessão mundial de graves proporções aproxima-se rapidamente, de forma inevitável. Seria temerário menosprezar os sinais que anunciam a tempestade próxima, tal como na década de 1930. Se ela não vier com a intensidade esperada, melhor, estaremos dando uma excelente contribuição para a concreção de um controle social eficaz e um grande passo para formatar uma democracia verdadeiramente responsiva.

Lembramos, por oportuno, que depois da "quinta-feira negra", 24 de outubro de 1929, a queda no valor da Bolsa norte-americana deu início à Grande Depressão, calamidade que envolveu todos os países do mundo. Sucede que o crash foi apenas um sintoma dos problemas que atingiam o mercado financeiro dos Estados Unidos, tanto assim que muitas ações recuperaram rapidamente o valor naquele mesmo ano, fato que encheu de otimismo o mercado e dissimulou a verdadeira situação por que passava o país. Em um primeiro momento, pensava-se que a quebra da Bolsa só teria atingido os investidores. Por 
isso as pessoas não perceberam que a crise era muito mais profunda e que a economia estava literalmente desmoronando.

A sociedade norte-americana só começou a sentir os efeitos do desastre quase dois anos depois, segundo informou ao G1 Harold Bierman, professor de Economia da Universidade Cornell. ${ }^{21}$ Ele poderia ter sido minimizado se o governo dos Estados Unidos não se quedasse inerte até 1933, início da gestão de Franklin Delano Roosevelt e do New Deal, acordo que marcou o fim do liberalismo clássico de auto-regulamentação do mercado. Ainda assim, é bom que se lembre, mesmo com o New Deal, a recuperação total da economia norte-americana só aconteceu no final da década de 1930, quando teve início a Segunda Guerra Mundial, fato histórico determinante para a reativação de todo o processo industrial norte-americano.

Esse erro foi decisivo para provocar a ação de auxílio aos bancos que enfrentavam dificuldades de liquidez desde 2007. O contraponto histórico, no entanto, só pode ser feito teoricamente, já que não é possível garantir os efeitos que se acreditava possíveis na época da Grande Depressão. Confirmando as previsões nada alentadoras dos especialistas, em 7 de outubro de 2008, o Fundo Monetário Internacional (FMI) divulgou relatório garantindo que a crise é inevitável, e no primeiro pronunciamento que Barak Obama fez sobre a crise, após as eleições, ficou claro que a atuação dos Estados Unidos terá que ser rápida, e que ele não subestima "a enormidade da tarefa de combater a crise financeira. Algumas das opções que faremos serão difíceis. E eu já disse e vou repetir: não será rápido, nem fácil. Mas a América é um país forte e conseguiremos superar esses problemas". Eis os pontos levantados pelo relatório do FMI:

O pior da crise financeira que afeta mercados em todo o mundo ainda está por vir, avalia relatório divulgado hoje (7) pelo Fundo Monetário Internacional (FMI). Segundo o documento, intitulado Relatório de Estabilidade Financeira Global, a crise deverá custar US\$ 1,4 trilhão a bancos e governos em todo o mundo.

$\mathrm{Na}$ edição anterior do relatório, em abril, o fundo havia estimado que as perdas não passariam de US\$ 945 bilhões. O organismo internacional classifica como "sem precedentes" a turbulência no sistema financeiro. E prevê que os bancos continuarão a registrar prejuízos relevantes por causa dos investimentos atrelados a hipotecas.

Somente para retomar o crédito, ainda que em níveis inferiores aos do início da crise, o FMI calcula que seriam necessários US\$ 675 bilhões nos próximos anos em aporte de capital para as instituições financeiras.

No documento, o FMI defende que os governos parem de esperar o mercado agir e atuem no resgate de instituições ameaçadas de falência. "A hora para soluções

21 Queda das bolsas em 1929 anunciava grande depressão americana. Disponível em: <http:/g1.globo.com/Sites/Especiais/Noticias/0,MUL763184-16107,00-QUEDA+DAS+BOLSAS+EM+ANUNCIAVA+ GRANDE+DEPRESSAO+AMERICANA.html>. Acesso em: 8 nov. 2008. 
a conta-gotas acabou. Conclamo os formuladores de políticas públicas a urgentemente enfrentar a crise em nível nacional com medidas abrangentes para restaurar a confiança no setor financeiro", destacou o diretor-gerente do Fundo, Dominique Strauss-Kahn, no relatório.

O texto também pede a cooperação rápida entre países para combater a escassez de crédito. "Os governos nacionais precisam coordenar esses esforços de maneira muito próxima para trazer de volta a estabilidade no sistema financeiro internacional." 22

Do relatório extrai-se que a crise já era esperada muito antes dos acontecimentos de outubro de 2008. Em abril, já se estimavam perdas de quase US\$ 1 trilhão, mas os governos também ignoraram as nuvens carregadas que indicavam a tormenta próxima e a potencialidade da crise antecipadamente anunciada, tal como aconteceu em 1929.

No Brasil, mesmo após a chamada "segunda-feira negra", 6 de outubro de 2008, as autoridades continuaram a repetir que a crise não nos alcançaria, uma vez que a reserva de US\$ 208 bilhões seria suficiente para garantir a imunização necessária para a epidemia econômica que se alastrou pelo mundo. O Presidente da República chegou a fazer um pronunciamento afirmando que esse era um problema norte-americano, não brasileiro, mas poucos dias depois quase todas as autoridades foram obrigadas a reconhecer o óbvio: a crise de 2008 não tem fronteiras, nem há imunizados. A única exceção ficou por conta do improvisado Ministro da Fazenda, que na reunião do Grupo dos 20, em São Paulo, continuou afirmando que o "pior já passou". A esse respeito, da negativa pura e simples da crise como forma de poupar o povo de preocupações desnecessárias, lembramos a declaração feita pelas autoridades norte-americanas no dia seguinte à quinta-feira negra, tal como estampada no jornal $O$ Estado de S. Paulo, edição de 25/10/1929: “Os funcionários do Thesouro declaram que a situação da Bolsa de Nova York constitue simplesmente uma reacção thecnica, não se devendo a um declinio real nas condições dos negócios". Essa nota, aliás, mereceu metade do destaque dado à notícia que está a seu lado: "A imprensa italiana refere-se com enthusiasmo ao noivado do principe Humberto".

É claro que essa reserva dá boas condições financeiras ao País para suportar o crash inicial, mas o que acontecerá se a crise for tão longa quanto apregoam? Diante das posições desfavoráveis assumidas pelos financistas, como indicam as medidas desesperadas tomadas em conjunto por quase todos os países que possuem economias significativas, não seria demasia prever que as reservas brasileiras são insuficientes para

22 EMPRESA Brasileira de Comunicação (EBC). Disponível em: <http://www.agenciabrasil.gov.br/ noticias/2008/10/07/materia.2008-10-07.1640318085/view>. Acesso em: 3 nov. 2008. 
combater a crise interna e, ao mesmo tempo, manter uma reserva logística suficiente para enfrentar os tempos difíceis que se avizinham.

Nesse sentido, pensamos que as semelhanças entre o desastre econômico dos anos 1930 e as crises do século XXI não devem ser buscadas comparando as perdas havidas nas Bolsas de Valores, meros sintomas da doença que havia muito vinha minando a economia dos Estados Unidos e o sistema financeiro internacional. Como bem apontou o presidente francês Sarkozy, o olho do furacão recebe estímulos contínuos do descontrole sobre o sistema financeiro global, já que a crise foi gerada em bancos de investimentos livres, na maior parte do mundo, da supervisão dos bancos centrais e de outros organismos de controle. Não que inexistam dispositivos reguladores, eles existem e estão expressos nas normas formuladas pelo Banco de Compensações Internacionais (Bank of International Settlements - BIS), de Basiléia, mas foram negligenciados pelas grandes potências. Hoje, o mundo inteiro paga por essa negligência.

Nos Estados Unidos, especialmente, a tardia visão liberalista do presidente Bush fez declarada opção pela desregulamentação do mercado, deixando-o à deriva em um mundo completamente diferente daquele que gerou a auto-regulamentação do mercado. $\mathrm{O}$ Bretton Woods proposto por Sarkozy ao abrir uma reunião de emergência do Conselho Europeu, por ele chefiado, teve como pressuposto o reconhecimento de que os europeus falharam na fixação de padrões de segurança para o sistema financeiro e de que é preciso chegar a um consenso sobre o órgão de supervisão de instituições financeiras para alcançar uma verdadeira refundação do sistema financeiro internacional.

Como se pode perceber, a única mudança realmente eficaz aguardada é uma completa e profunda formatação da conduta que cada Estado deve observar, tanto internamente quanto no convívio direto com a sociedade das nações. O editorial do jornal O Estado de S. Paulo de 08/11/2008, intitulado “A piora do quadro mundial”, além de trazer notícias preocupantes sobre a economia mundial, alerta que o Brasil e os outros Estados

agirão com acerto se levarem a sério as projeções do FMI. Em vez de contestálas, devem esforçar-se para produzir resultados melhores do que aqueles indicados nas projeções. Também no Brasil há espaço para o uso da política fiscal como estimulante da economia. Mas não, como em muitos outros países, pela mera expansão do gasto. O governo poderá ampliar o alívio tributário, já adotado timidamente, se tiver disposição e competência para cortar despesas inúteis ou pouco produtivas. 
A longa exposição dos fatos e as prognoses da economia mundial mostram-se indispensáveis porque estamos vivenciando mais um capítulo da sucessão de rupturas e descontinuidades em nossa trajetória de vida. Utilizamos aqui o termo ruptura no sentido de fato excepcional, que rompe a continuidade da sequiência de fatos históricos, como o tratado de João Sem-Terra, a independência norte-americana, a Revolução Francesa, a Revolução Industrial, as duas grandes guerras e outros fatos de extrema influência sobre a vida social, econômica, política e jurídica das nações. Assemelha-se, em essência, ao descrito por Hanna Arendt em Between past and future: um acontecimento tão poderoso como aquele capaz de produzir um hiato entre o passado e o futuro, um verdadeiro divisor de águas, com o anterior esfacelamento dos padrões e categorias do pensamento.

Esse espaço deixado por um mundo agonizante e por outro que precisa desesperadamente ser reconhecido para poder assumir o seu lugar amolda-se exatamente à realidade que determinou a mudança do paradigma sociocultural dominante. Por esse ângulo, é possível entender a ruptura do processo de desenvolvimento daquilo que deveria ser, modernamente, o Direito Público. Ora, a ruptura do processo histórico exige a remodelação da economia, da política e, especialmente, do Direito, já que as soberanias são compartilhadas e o Estado-nação se vê obrigado a ceder espaço a um novo tipo de interesse público: o interesse compartilhado entre os cidadãos do mundo, compulsoriamente solidários na difícil luta pela sobrevivência econômica. A economia mundial passou a condicionar, ela própria, a ação dos Estados. Isso resulta, na prática, na limitação da capacidade que os governos têm de implementar políticas públicas e, por extensão, assegurar direitos fundamentais.

Esse novo paradigma ainda não foi nomeado, mas Boaventura Santos chamou-o "paradigma de um conhecimento prudente para uma vida decente" ${ }^{23}$ Como o presente não é mais que um degrau galgado pela civilização, a realidade atual deve fornecer a verdadeira dimensão do Direito vigente, deixando antever as prováveis mudanças que precisam ocorrer no presente e no futuro. Para compreender o alcance dos institutos que compõem o Direito e as limitações legais que sujeitam o Estado, é preciso pressentir a sua estrutura e as dependências recíprocas de todo o sistema normativo com o momento histórico vivido. Se aceitarmos que o Direito deve ser um reflexo da sociedade que pretende regular, ele não pode contentar-se em ser um instrumento de justiça formal, tomada como simples imperativo categórico, mas, sim, reconhecer a realidade do estado de

23 SANTOS, Boaventura de Sousa. A crítica da razão indolente: contra o desperdício da experiência, para um novo senso comum. 6. ed. São Paulo: Cortez, 2007, v. 1, p. 16. 
exceção permanente em que vivemos. Se aceitarmos que elementos da realidade (fatos que denotam a exceção duradoura) habitam a norma, regras de Direito não se esgotam em seus textos. Exatamente por serem abstratas e gerais, ou seja, desprovidas de referências à realidade da vida, as normas só se completam no ato interpretativo que leva em consideração o momento histórico vivido.

Assim, o Direito não pode desconsiderar o estado de exceção permanente em que vivemos. Alertamos, contudo, que a ênfase dada à crise econômica atual não significa que ela, por si só, possua relevância suficiente para determinar a ruptura suprademonstrada ou caracterizar o estado de exceção anunciado. Ela é apenas a ponta mais visível de uma crise muito mais profunda de liquidez, de confiança no sistema financeiro, em razão da falência das engenharias financeiras gestadas no ventre de aplicações lastreadas em derivativos e outros tipos de artifícios desenvolvidos por mefistos modernos, que não são demoníacos, mas, sim, servem à mesma causa. Pode-se dizer deles, o que Hanna Arendt disse de Eichmann: fazem monstruosidades mas não são monstros, livram-se de peias éticas e agem no vazio da lei, na ausência de regulamentos específicos, movidos pela própria ganância e por conhecimentos do mercado, próprios ou de seus idolatrados gurus. Esquecem-se, todavia, e por isso devem ser preventivamente contidos, da lição de Kant, rememorada por Hanna Arendt em Eichmann em Jerusalém: um relato sobre a banalidade do mal: "para ele [Kant] todo mundo é um legislador no momento em que começa a agir: usando essa 'razão prática' o homem encontra os princípios que poderiam e deveriam ser os princípios da lei'", ${ }^{24}$

Como se não bastassem as graves crises econômicas mundiais, a vida nacional torna-se ainda mais desanimadora quando consideramos a sangria ininterrupta e imoral de nossas reservas. Esse desperdício era a mola propulsora de nossa tese, escrita em 2007, muito antes dos acontecimentos de outubro de 2008. É evidente, portanto, que os novos fatos não inspiraram a tese, apenas vieram a fortalecê-la, porquanto a crise financeira atual é produto de uma crise econômica anterior muito mais profunda, de confiança.

Pelas poucas informações que chegam ao conhecimento da população, o desperdício no Brasil, em decorrência direta da corrupção e ineficiência administrativa, consome um terço da arrecadação nacional, ${ }^{25}$ o que equivale a $\mathrm{R} \$ 234$ bilhões por ano. Como não há outros estudos sobre esse tema, é temerário questionar a legitimidade dos

24 ARENDT, Hannah. Eichmann em Jerusalém. São Paulo: Schwarcz, 2003, p. 153.

25 O Globo, Caderno de Economia, p. 29, 4 out. 2006, que relata estudo do Instituto Brasileiro de Planejamento Tributário (IBPT). 
dados ora apresentados. O princípio da precaução tem plena aplicação na atenção que deve ser dispensada a esses números, porque a cautela que ele exige deve ser efetivada antes da absoluta certeza científica sobre se tal situação configura de fato uma ameaça real de dano econômico e social. Esse princípio impõe uma projeção realista sobre fatos potencialmente perigosos em seus prováveis desdobramentos, mas ainda não ocorridos. Não há, de resto, nenhuma razão racional para contestá-los, já que os danos previstos por ocasião da qualificação deste trabalho estão plenamente confirmados pelos graves acontecimentos que sacudiram a economia mundial em 2008. Exatamente por isso, juristas do porte de Diogo de Figueiredo Moreira Neto ocuparam-se desse estudo com bastante seriedade, alertando que,

\begin{abstract}
para se ter uma idéia do que representa esta fantástica cifra de desperdício, ela seria suficiente para cobrir o déficit, sempre crescente, da previdência social, por quase seis anos seguidos; construir 13 milhões de moradias populares ao custo unitário de R \$17.000,00 reais; construir 19,5 milhões de novas salas de aula, ao custo de $\mathrm{R} \$ 12.000,00$ cada uma; ampliar para todas as cidades do país o sistema de água canalizada e esgoto tratado, obra estimada em 220 bilhões de reais pela Associação das Empresas de Saneamento Básico Estaduais, ou restaurar toda malha rodoviária estadual e federal, de 156 mil quilômetros, e mantê-la por sessenta anos consecutivos, segundo os cálculos da Associação Brasileira de Infra-Estrutura e Indústrias de Base. É nesse quadro que assoma, terrível e acabrunhante, a constatação da inanidade dos instrumentos jurídicos tradicionais para lograr reduzir a níveis admissíveis esse imenso desperdício dos preciosos recursos aportados pela sociedade, que, se fossem eficientemente empregados, poderiam superar tanta carência e marginalidade, cumprindo a tarefa constitucional que se espera do Estado-solidário. ${ }^{26}$
\end{abstract}

Da mesma forma, no editorial intitulado "Dinheiro de ninguém", de $O$ Estado de $S$. Paulo, o leitor, estarrecido, é informado sobre o relatório do Ministro Ubiratan Aguiar, do Tribunal de Contas da União (TCU), que descreve como órgãos públicos que já foram extintos jamais prestaram contas:

Considerando as justificativas não entregues pelos Ministérios, ou aquelas apresentadas, mas não analisadas, repasses de nada menos que R \$ 12,5 bilhões, feitos pela União, estão sem prestação de contas. O atraso médio na prestação de contas de programas que utilizam recursos de transferências voluntárias do governo federal está em torno de 3,9 anos - o que equivale, praticamente, a um mandato presidencial inteiro (...) Não poderia haver combinação mais propícia para que se dilapide o patrimônio público com conforto e segurança. ${ }^{27}$

26 MOREIRA NETO, Diogo de Figueiredo. Novos horizontes para o direito administrativo: pelo controle das políticas públicas. Ecos de um congresso: a próxima missão. Revista de Direito do Estado, ano I, n. 4, out./dez. 2006, p. 406-407.

27 O Estado de S. Paulo, p. A3, 30 set. 2007. 
Diante desses depoimentos, como bem advertiu o Ministro Marco Aurélio, do Supremo Tribunal Federal, pode-se dizer que o Brasil se tornou um país de faz-de-conta. Faz de conta que não temos uma carga tributária insuportável, que as receitas públicas são eficientemente empregadas para resguardar o mais lídimo interesse público, que ninguém morre nos corredores frios dos hospitais ou nas filas da Previdência, nem temos que nos esquivar de menores abandonados que tentam, inutilmente, fazer malabarismos para motoristas desinteressados nos semáforos das cidades, e faz de conta que não perdemos, anualmente, 1/3 de nossa arrecadação tributária, o que quase alcança o valor anual de nossas exportações, por corrupção e ineficiência administrativa. Faz de conta, também, que o governo tem razões de sobra para comemorar o fato de apenas uma pessoa, em cinco, viver em um deprimente estado de miséria absoluta.

$\mathrm{O}$ crescente sentimento de impunidade em relação àqueles que surrupiam o dinheiro público e a impotência dos súditos que aprendem a conviver com os assaltos tolerados diariamente por seus representantes recebem o contínuo estímulo da ineficácia dos modelos tradicionais de controle. Nada obstante, em nome de uma falsa segurança, insistimos em preservar modelos arcaicos de hermenêutica constitucional e administrativa que não mais atendem a complexidade das novas formas de atuação do Estado, especialmente em face do estado de exceção permanente em que nos encontramos.

Presume-se que o mundo desenvolveu conhecimentos suficientes para enfrentar e ultrapassar a crise atual, mas resta evidente que controlar essa crise não é o mesmo que ultrapassar o período de turbulência econômica. Na seqüência, assim como chegamos a ela, inúmeras crises de menor intensidade continuarão a se reproduzir, de modo igualmente devastador, por um intervalo de tempo incalculável.

Não apenas pelos resultados negativos da economia em outubro de 2008, já que esses fatos representam tão-somente os sintomas da crise latente que há muito se desenvolve, mas pelos tempos difíceis que estão por vir - e virão -, é preciso desenvolver um método eficaz de controlar e preservar o dinheiro público e o seu correto investimento. Não é mais possível, diante da gravidade dos fatos, atermo-nos à mumificação dos métodos de controle e, por extensão, do Direito Público. O Direito Constitucional e o Direito Administrativo não podem seguir convivendo com suas versões paralelas apenas em nome do estado de necessidade. Isso era tolerável quando se tinha a esperança, sempre presente, de que as crises fossem rápidas e voláteis. Agora, o horizonte da normalidade democrática não é mais visível. Em verdade, havia muito não se viam as cores fortes do 
horizonte, mas possuíamos uma espécie de convicção cega que transformava o cinzento da crise em uma azulada tranqüilidade.

A nossa proposta, diante desses fatos, é permitir um sistema de controle social eficaz de políticas públicas, provocando a integração da sociedade nesse controle, mediante a ação do Poder Judiciário e, especialmente, por suas próprias atribuições constitucionais, do Tribunal de Contas da União. A possibilidade apresentada pretende ser, no momento, a melhor opção para assegurar efetividade às ações públicas e conciliar o equilíbrio desejável entre justiça e liberdade, legalidade e desregulamentação. Evidentemente, a opção não pode ser tomada como panacéia de todos os males, mas o chamamento do cidadão para participar do diálogo nacional certamente provocará o aprimoramento de todos os outros métodos de controle. 


\title{
ESTADO CONTEMPORÂNEO E NEOCONSTITUCIONALISMO. PREMISSAS PARA A SUA COMPREENSÃO
}

\author{
As transformações históricas afetam tanto \\ as perguntas como as respostas \\ (Ortega y Gasset)
}

Segundo Ortega y Gasset, as transformações históricas determinam novas perguntas e exigem, evidentemente, respostas que levem em conta as alterações ocorridas. De fato, o neoconstitucionalismo não pretende alcançar somente a difícil compatibilização do Estado de Direito com o Estado Social e o Estado de Direito Democrático, exatamente porque ele é mais que a síntese dessas teorias. Canotilho ensina que

\begin{abstract}
Constitucionalismo é a teoria (ou ideologia) que ergue o princípio do governo limitado indispensável à garantia dos direitos em dimensão estruturante da organização político-social de uma comunidade. Neste sentido, o constitucionalismo moderno representará uma técnica específica de limitação do poder com fins garantísticos. O conceito de constitucionalismo transporta, assim, um claro juízo de valor. É, no fundo, uma teoria normativa da política, tal como a teoria da democracia ou a teoria do liberalismo. ${ }^{28}$
\end{abstract}

Loewenstein, no mesmo sentido, afirma que

\begin{abstract}
la historia del constitucionalismo no es sino la búsqueda por el hombre político de las limitaciones al poder absoluto ejercido por los detentadores del poder, así, como el esfuerzo de establecer una justificación espiritual, moral o ética de la autoridad, en lugar del sometimiento ciego a la facilidad de la autoridad existente. $^{29}$
\end{abstract}

Paolo Comanducci expressa-se sobre o neoconstitucionalismo da seguinte forma:

28 CANOTILHO, José Joaquim Gomes. Direito constitucional e teoria da constituição. Coimbra: Almedina, 1997, p. 45-46.

29 LOEWENSTEIN, Kart. Teoría de la constituición. Barcelona: Ariel, 1983, p. 150. 
Como teoría, el neoconstitucionalismo representa por tanto una alternativa respecto a la teoría iuspositivista tradicional: las transformaciones sufridas por el objeto de investigación hacen que ésta no refleje más la situación real de los sistemas jurídicos contemporáneos. En particular, el estatalismo, el legicentrismo y el formalismo interpretativo, tres de las características destacadas del iuspositivismo teórico de matriz decimonónica, hoy no parecen sostenibles. ${ }^{30}$

Cremos que um neoconstitucionalismo garantidor dirige-se especialmente contra o fetiche da lei, que tem determinado, até agora, a indesejável reserva exclusiva de iniciativa dos órgãos legitimados pela democracia representativa para implementar os direitos assegurados na Constituição. A resignada passividade da sociedade tem transformado a Constituição em uma espécie de carta de intenções que serve somente para dirigir a produção legiferante do Estado e para fundamentar as decisões judiciais que favorecem aqueles raros privilegiados que podem recorrer ao Judiciário. No imenso oceano de agressões cometidas à dignidade do ser humano, portanto, é insignificante o número de casos que recebem correção judicial. A Constituição repousa inerte, longe do alcance da grande maioria da população, como simples estímulo para alcançar uma condição social que garanta aos emergentes da pobreza endêmica as benesses de uma cidadania quase inalcançável.

O que se quer deixar assentado é que, para a grande maioria da população, os lindos enunciados e promessas constitucionais são meramente retóricos. A existência formal de meios capazes de preservar a dignidade humana, para a grande maioria das pessoas, é uma promessa reconfortante, mas ineficaz. Direitos fundamentais que são garantidos com o emprego de processos contenciosos não são representativos de direitos fundamentais garantidos.

Direitos e garantias constitucionais refletem uma idéia, uma promessa de efetividade, que pode ou não se concretizar, de maneira ordinária, na vida de todos os integrantes de uma coletividade. Sob esse foco, o recurso ao Judiciário é o mais sublime meio de respeito à dignidade dos oprimidos. No entanto, se ele for o caminho necessário para preservá-la, e não uma parte da geração concreta do direito, a sua atuação será pífia e visivelmente insuficiente.

Paulo Bonavides reconhece a dificuldade e expõe que "o verdadeiro problema do Direito Constitucional de nossa época está, a nosso ver, em como juridicizar o estado social, como estabelecer e inaugurar novas técnicas ou institutos processuais para garantir

30 COMANDUCCI, Paolo. Constitucionalización y teoría del derecho. Conferência pronunciada em 23 de agosto de 2005 na Academia Nacional de Direito e Ciências Sociais de Córdoba, Argentina. 
os direitos sociais básicos, a fim de fazê-los efetivos". ${ }^{31}$ É verdade, o constitucionalismo de nossos dias deve ter em vista a efetividade dos princípios mais caracterizadores do Estado Democrático de Direito: o direito à cidadania, à dignidade da pessoa humana, aos valores sociais do trabalho e ao pluralismo político. ${ }^{32}$ Já no Preâmbulo, os representantes do povo, reunidos em seu nome, deixam claro que a obra que dão à luz, detalhadamente dirigente, só encontra justificativa se for utilizada para construir um Estado Democrático, "destinado a assegurar o exercício dos direitos sociais e individuais, a liberdade, a segurança, o bemestar, o desenvolvimento, a igualdade e a justiça como valores supremos de uma sociedade fraterna, pluralista e sem preconceitos, fundada na harmonia social". Nesse sentido, de que a Constituição não se limita a enunciar considerações de ordem valorativa, exige a realização desses valores, Tercio Sampaio Ferraz enfatiza que

\begin{abstract}
O intérprete obriga-se não só a ir além da letra e da estrutura formal da norma, para buscar-lhe a ratio imanente, por meio de métodos teleológicos, sociológicos e mesmo axiológicos, mas a visar um procedimento transformador das próprias realidades sociais: interpretação de legitimação.

$\mathrm{Na}$ interpretação de legitimação, o intérprete não busca, apenas, revelar o sentido da norma constitucional em seu contexto real, nem mesmo somente concretizar padrões genéricos de sentido em casos particulares, mas modificar a própria realidade, em conformidade com aquele sentido. Esse trabalho interpretativo não se confunde com a aplicação judiciária da Constituição, pois não visa a produção de normas individuais, mas se dá ainda no plano conceitual. Trata-se, na relação entre texto e contexto, de uma compreensão do texto capaz de alterar o contexto, dando-lhe um sentido legitimante. ${ }^{33}$
\end{abstract}

Tercio toca exatamente no ponto sensível que se quer deixar estabelecido: a interpretação legitimante da Constituição só tem sentido se ocorrer ainda no plano conceitual, pois, apesar da importância conformadora da jurisprudência, é inegável a pequena abrangência das normas individuais. Quem acompanha a atividade diária da Administração e as decisões de nossos Tribunais sabe bem que, por mais pacífica que seja uma orientação jurisprudencial, a realidade dificilmente é modificada. Década após década os procuradores das três esferas de governo lutam, até o último recurso, para evitar o

31 BONAVIDES, Paulo. Curso de direito constitucional. São Paulo: Malheiros, 1997, p. 338.

32 Constituição da República Federativa do Brasil:

“Art. $1^{\circ}$ A República Federativa do Brasil, formada pela união indissolúvel dos Estados e Municípios e do Distrito Federal, constitui-se em Estado Democrático de Direito e tem como fundamentos:

I - a soberania;

II - a cidadania;

III - a dignidade da pessoa humana;

IV - os valores sociais do trabalho e da livre iniciativa;

$\mathrm{V}$ - o pluralismo político.

Parágrafo único. Todo o poder emana do povo, que o exerce por meio de representantes eleitos ou diretamente, nos termos desta Constituição."

33 FERRAZ JR., Tercio Sampaio. Direito constitucional, p. 7-8. 
trânsito em julgado de questões jurídicas impossíveis de reverter. É essa, aliás, a conduta que o sistema impõe à sua atuação. Como se não bastassem os recursos necessários, os voluntários, estimulados pela exigência de trânsito em julgado para executar o Poder Público, o administrado ainda precisa se conformar com cláusulas como a do financeiramente possível, calotes legalizados de precatórios e com a impossibilidade prática de intervenção em entes federados.

Difícil crer em legitimação da Constituição por meio do controle jurisdicional. Em se tratando de controle de políticas públicas, nas quais, via de regra, não há ilegalidades ou inconstitucionalidades aparentes a sanar, uma vez que elas apenas podem ser sugeridas ou pressentidas, parece impossível alcançar um controle eficaz capaz de evitar um dano que não se apresenta nem ao menos provável. Desse modo, a hermenêutica tradicional de subsunção do fato à norma torna-se bastante problemática. A questão passa a ser de transformação da realidade conforme um projeto político. Como é intuitivo, as inúmeras variantes possíveis, todas elas aceitáveis pelos padrões usuais da lógica, da história, da teleologia e da análise sistemática, não permitem a segura eleição de métodos corretivos de programas e caminhos políticos implicitamente aceitos no texto constitucional. Até onde o Judiciário pode adentrar nessa nebulosa via? Não se deve esquecer que há, aquém do horizonte, um ponto em que é indispensável reconhecer um poder discricionário da Administração, sob pena de sermos levados pelo turbilhão do regresso ao infinito. Qualquer que seja a forma como a regressão é evitada, a legitimação do Direito só poderá ser alcançada se puder contar com uma eficiente participação da sociedade.

A função de legitimação das aspirações sociais e a atuação do Judiciário serão mais bem explicadas no desenvolver da tese, mas foi imprescindível abordar a questão neste momento para trazer o ensinamento de Forsthoff: "a superação do positivismo não é de maneira nenhuma o abandono da positividade do direito". ${ }^{34}$ Essa volta à positividade é a salvaguarda necessária para evitar que as decisões possuam, de alguma maneira, lastro metafísico.

Será, portanto, totalmente infrutífero postular novos meios de controle ou insistir em manter os padrões tradicionais normalmente aceitos para compreender e aplicar o Direito Administrativo, totalmente voltado para a simplicidade do ato administrativo, se a idéia for manter um constitucionalismo que não existe mais. Aliás, o modo de se entender o Direito Público, como um todo, também não se ajusta mais aos cânones e paradigmas

34 FORSTHOFF, Ernst. Apud DERANI, Cristiane. Direito ambiental e econômico. São Paulo: Saraiva, 2008, p. 3. 
reconhecidos até há bem pouco tempo. A Constituição, sem alteração de texto, não é mais aquela promulgada em 1988, nem os métodos hermenêuticos constitucionais são os mesmos. Como então entender separação de poderes e distribuição de competências em vista dessa nova visão de constitucionalismo? Por outro lado, o controle externo exercido pelo Tribunal de Contas ainda estaria limitado pelo que foi alinhavado pelo poder constituinte, quase no mesmo instante em que ocorreu a grande ruptura do Direito Público? Institutos jurídicos e princípios constitucionais, como o democrático e o da efetividade, que mal começavam a ser desenvolvidos há 20 anos, certamente não se amoldam a uma leitura estática da Constituição.

Em se falando de princípios que não possuíam o mesmo peso na época da Assembléia Constituinte e que no constitucionalismo atual tiveram sua importância notavelmente relevada, bem como de políticas públicas que dão concreção aos princípios e fundamentos da República Federativa do Brasil, cabe lembrar a lição de José Carlos Barbosa Moreira ao reclamar uma reinterpretação de regras e princípios para adequá-los aos novos valores:

Põe-se ênfase nas semelhanças, cobre-se um véu sobre as diferenças e conclui-se que, à luz daquelas, e a despeito destas, a disciplina da matéria, afinal de contas, mudou pouco, se é que mudou. É um tipo de interpretação (...) em que o olhar do intérprete dirige-se antes ao passado que ao presente, e a imagem que ele capta é menos a representação da realidade que uma sombra fantasmagórica. ${ }^{35}$

\subsection{ESTADO DEMOCRÁTICO DE DIREITO}

O Estado, na segunda metade do século XX, recebeu diversas denominações, todas pretendendo sinalizar a sua característica mais notável, como Estado pós-liberal, Welfare State, Estado-gestor, Estado Social, Estado regulador, Estado-rede e muitas outras denominações. Nenhuma delas, entretanto, é capaz de identificar o Estado contemporâneo. Ele é, ao mesmo tempo, tudo isso e muito mais, posto que as características que sobrelevam acentuam-se alternadamente, conforme o momento histórico vivido e o contexto em que é lembrado. Mas nenhum deles completou o seu ciclo ou deixou de evoluir. Assim, pode-se dizer que o Estado contemporâneo é, tanto quanto um Estado regulador, um Estado pós-liberal.

35 MOREIRA, José Carlos Barbosa. O Poder Judiciário e a efetividade da nova constituição. Revista Forense, Rio de Janeiro, n. 304, dez. 1988, p. 152-154. 
Não obstante isso, é de se reconhecer que a grande ruptura, pelo menos em épocas mais recentes, aconteceu com a transformação do Estado de Direito, de postura individualista e abstrata, em Estado Social, cuja característica principal reside no objetivo de abreviar o hiato existente entre Estado e sociedade com o objetivo de regularizar as relações sociais e econômicas, cada vez mais complexas, que obrigam o Poder Público a proporcionar segurança e certeza econômica aos indivíduos por meio da garantia de um mínimo bem-estar. No Brasil, a tarefa encontrou dificuldades extremas para prosperar, pois o pacto social-liberal que pretendia fundar buscava a revolução do social sem abandonar a segurança do liberalismo tradicional. Por isso que se costuma dizer que o nosso Estado passou a ser Social sem nunca deixar de ser Liberal. Isso, evidentemente, repercutiu no Estado real que obtivemos. Também aqui tem aplicação a "interpretação retrospectiva" de José Carlos Barbosa, no sentido de que a procura por novas soluções no Estado Social é feita da maneira mais condizente possível com o Estado Liberal. O fracasso foi inevitável, pois, enquanto o Estado Liberal se limitava a assegurar a justiça formal, o Estado Social pretende concretizar a justiça material, ou seja, efetiva.

Outro problema, que continua a ser enfrentado até hoje, reside na herança de todo um ordenamento jurídico composto por leis pré-constitucionais e, portanto, pendentes de uma nova leitura. Não estamos falando de recepção constitucional, nem de inconstitucionalidades evidentes, mas de uma sutil inadequação, no exame do caso concreto, daquelas normas com o novo regime imposto pela Constituição de 1988. Isso faz com que o sistema normativo apresente-se como uma unidade apenas formal. Materialmente falando, ele se mostra como uma colcha de retalhos. Essa situação exige algo que não tem sido feito, dado o seu extremo grau de dificuldade, já abordado por Peter Häberle:

\footnotetext{
Diferentemente das leis pós-constitucionais, as leis pré-constitucionais não devem ser consideradas como interpretação constitucional do legislador. Assim, elas reclamam não só um tratamento processual diferenciado, como também exigem um exame mais rigoroso quanto ao seu conteúdo. ${ }^{36}$
}

A dificuldade prática de exercer um controle rigoroso sobre essa adequação não quer significar, no entanto, que ele não deva ser feito. Nesse aspecto, teríamos um controle não de constitucionalidade, mas de adequação, que pode ser efetivado com o emprego de

36 HÄBERLE, Peter. Hermenêutica constitucional: a sociedade aberta dos intérpretes da constituição: contribuição para a interpretação pluralista e 'procedimental' da constituição. Tradução de Gilmar Ferreira Mendes. Porto Alegre: Fabris, 1997. 
técnicas hermenêuticas constitucionais. Nesse âmbito, encontramos importantes leis financeiras cujo texto merece ser interpretado conforme a Constituição.

Escusado dizer que essa patologia também alcança a jurisprudência e todo o sistema de controle interno e externo dos órgãos públicos, tendo em vista a impossibilidade física de apreciar o brutal número de processos submetidos aos órgãos julgadores. A recomendação de que a interpretação da Constituição não é para ser procedida à margem da realidade, sem que se compreenda como elemento da norma resultante da interpretação, fartamente enunciada pelos Tribunais, torna-se mera retórica, uma vez que só aplicável entre as partes. A contradição entre Constituição formal e Constituição material, que resulta na permanente necessidade de conformar fatos constituídos a fatores constituintes, torna-se, dessa maneira, totalmente incontornável.

A ordem econômica e social prevista na Constituição, a despeito de sua exigência de efetividade, acaba possuindo uma característica apenas programática. A força normativa da ordem instalada, apesar da retórica, possui quase nenhum raio de alcance. O processo de transformação do Estado, que ambiciosamente a Constituinte de 1987 pretendia instaurar, deu à luz um Estado Social conservador, que alternava a eficácia da norma revolucionária com abstrações e pressuposições sem fundamento real. É lógico que as ideologias abstratas escamoteiam as dificuldades, assim, o "homem" nunca chega a ser o mundo do homem, como queria Marx. Ele só deixa de ser um ser abstrato, fantasmagórico, instalado fora do mundo, nas raras oportunidades em que poucos privilegiados podem bradar os seus direitos mais básicos às portas dos tribunais. Não, um Estado não é feito de exceções, às quais se atribui mais relevância que ao oceano de ultrajes cometidos, diariamente, contra o homem concreto. Do homem abstrato, sem existência real, passamos à Constituição abstrata, apartada da vida real, que são todas as Constituições que encerram uma acentuada contradição entre as suas expressões formal e material. Se quisermos dar um exemplo atual dessas contradições, podemos salientar que, apesar das centenas de milhares de pessoas que morrem anualmente por falta de remédios e tratamento adequado, sentimo-nos confortados e esperançosos com os poucos casos, estatisticamente desprezíveis, nos quais a Justiça determinou imediato tratamento e os direitos fundamentais foram magnificamente respeitados.

De qualquer modo, como se verá, o que falta é vontade política para as reformas determinadas pela Constituição, pois, apesar de tudo, a Carta de 1988 foi muito bem elaborada. É que o modelo de Estado Democrático de Direito proposto permite a justaposição do contorno jurídico do Estado de Direito com o político do Estado Social, 
cuja concretização pressupõe um Estado politicamente ativo e uma simbiose (no sentido de junção sem perda de suas individualidades) entre o político e o jurídico e entre o Estado e a sociedade. Foi exatamente aí que falhamos, não pela insuficiência do modelo, mas pela ingênua crença de que um regime democrático pudesse ser alcançado somente com o voto dos verdadeiros mandantes. Alijada do processo de legitimação da Constituição e da vida pública, a escolha popular assemelha-se à vontade majoritária de um bando de carneiros, tal qual imaginado por Nietzsche. As oportunidades de manifestação efetiva oferecidas aos cidadãos não podem resumir-se aos poucos episódios eleitorais, incapazes de lhes prestar as homenagens merecidas.

\subsection{ESTADO E SOCIEDADE CIVIL. DEMOCRACIA QUALIFICADA E LEGITIMAÇÃO}

A resposta à questão proposta pelo professor de Filosofia Política da Universidade Georgetown, Henry S. Richardson, no artigo "Em defesa de uma democracia qualificada", dá a dimensão exata do que se espera de um Estado Democrático: democracia ainda é "o governo do povo, pelo povo e para o povo", ou a expressão de Lincoln, nos dias de hoje, possui somente um sentido retórico de "governo do povo"? É verdade que o governo deve sempre pautar suas decisões para prover os interesses do povo, mas o sistema constitucional de representatividade permite presumir um governo realmente "do povo"? O Estado que realizar esse prodígio terá desenvolvido, sem dúvida, uma democracia qualificada.

Essa questão leva a outra: o Congresso pode ser considerado como o povo reunido? O mestre de Washington responde que a última questão não passa de uma "ingênua sinédoque". É dizer, não se pode trocar a palavra que indica o todo (povo) por outra que indica apenas uma parte dele (Congresso), porque não há equivalência entre os vocábulos. A legitimidade conferida nas urnas aos integrantes do Congresso não lhes atribui um bill de poderes ilimitados, como uma procuração em branco, válida até o último dia da legislatura. Por outro lado, embora a Constituição Federal tenha sinalizado, exaustivamente, na direção da participação popular no controle da Administração Pública, os meios atualmente conhecidos não conseguiram amenizar o abismo existente entre sociedade e Estado. Comissões e grupos de cidadãos manipulados por interesses políticos menores não podem, à evidência, tornar menos falsa a sinédoque do termo povo com o 
vocábulo grupo que representa o povo. A falsidade, a nosso ver, é maior ainda que a equivalência povo e Congresso.

Sendo assim, ainda se pode falar em "governo do povo"?

Richardson sustenta que sim, é possível:

\begin{abstract}
Trata-se de algo muito simples: o processo político tem de ser estruturado de modo tal, que respeite adequadamente a autonomia de cidadãos individuais. Se o processo for estruturado desta forma, podemos considerar as decisões daí decorrentes um reflexo da vontade popular. Seria impossível garantir a participação ativa dos cidadãos autônomos no processo de decisão, se fosse preciso remontar às origens históricas da Constituição ou se isso tivesse de ser expresso num único momento dentro do processo político. Em compensação, a formação de vontade popular distribuída ao longo da estrutura constitucional realmente parece exeqüível.

Chegamos, assim, a uma concepção liberal, republicana e qualificada de democracia, segundo a qual democracia quer dizer, na imortal frase cunhada por Lincoln, "o governo do povo, pelo povo e para o povo". 37
\end{abstract}

É verdade, soa totalmente ingênuo esperar que representatividade e participação popular adequada sejam concretizadas em um átimo, como efeito inafastável de um único ato: o voto formulado em eleições livres. Seria bom se as coisas fossem tão simples. A presunção de representatividade até o fim do mandato é extremamente relativa, desde que é impossível prever, na fase eleitoral, como o mandatário se portará quando tiver de decidir sobre as importantes e complexas questões concretas que a vida real fornece. Não, a representação popular eficaz é obra que nunca se esgota. Precisa ser lapidada dia a dia nos diálogos sensíveis entre autoridade constituída e opinião pública e entre opinião pública e opinião individual. Não se pode prescindir, portanto, de um processo longo e complexo, que irá incentivar e atrair o povo a assumir uma posição atuante e participativa, de pleno reconhecimento do valor de sua vontade e da possibilidade efetiva que tem de opor-se àquilo com que não concorda.

Nesse ponto, aproximamo-nos do tema proposto, que é o controle social eficaz de políticas públicas. No entanto, no dizer de Robert Post, ${ }^{38}$ é preciso que os cidadãos possam reconhecer naquela vontade geral a potencialidade de sua própria autoria. Essa potencialidade legitima até o resultado contrário aos interesses de uma determinada pessoa, desde que o procedimento por meio do qual a vontade geral é manifestada tenha idoneidade suficiente para que o cidadão não se sinta excluído da tomada de posição

37 RICHARDSON, Henry S. Em defesa de uma democracia qualificada. In: MERLE, Jean-Christophe; MOREIRA, Luiz. Direito e legitimidade, p. 194.

38 POST, Robert C. Democracia e igualdade. RDE - Revista de Direito do Estado, ano 1, n. 3, p. 6-7, jul./set. 2006. 
coletiva que deverá, forçosamente, acatar. Ele poderá acatá-la com irresignação, apenas por coação, ou obedecerá voluntariamente aos desígnios de uma maioria que, não obstante a resistência daquele foi incapaz de mudar. Guardadas as diferenças, pode-se lembrar de decisões que desaprovamos nos condomínios em que moramos. Se o síndico eleito, apoiado por um grupo de condôminos presentes em uma reunião que não foi precedida das formais garantias de publicidade, ou marcada maliciosamente no intervalo ou logo após um feriado prolongado, conseguir aprovar uma medida contrária ao nosso interesse, jamais a acataremos voluntariamente, exatamente porque não reconhecemos na vontade geral a potencialidade de nossa própria vontade. Isso certamente não acontecerá se participarmos da reunião e sairmos, democraticamente, vencidos. É desse tipo de legitimidade que falamos.

A questão será mais bem desenvolvida no item 8.1, mas se adianta a importante consideração de que, sem um efetivo reconhecimento da autonomia dos indivíduos e sem o permanente oferecimento de contestação perante as decisões do governo, o Estado não será, em essência, democrático. Estado Democrático de Direito não é uma atribuição que se possa autoproclamar, é uma posição política conquistada e sedimentada nas mais desimportantes e corriqueiras situações políticas que surgem na vida pública.

\subsection{DIVISÃO DE PODERES}

Em tema de superação da tripartição clássica de poderes, acreditamos, como Diogo de Figueiredo, que

\footnotetext{
a competência, longe de ser um instituto que reparte o Poder Estatal, simplesmente incumbe a determinados entes e órgãos a missão de exercitá-lo, seja de modo exclusivo, compartilhado ou em associação, daí por que Paul Laband denominava a Constituição de Kompetenz von Kompetenz. ${ }^{39}$
}

O princípio da separação dos poderes não conduz, absolutamente, à suposição de que as competências distribuídas estejam prévia e rigorosamente delimitadas, já que a separação é muito mais política que funcional. É verdade, ela não procura assegurar o poder, nem pode servir a objetivo que não se apresente em total harmonia com o interesse público. Quem melhor se expressou sobre o assunto foi Loewenstein:

39 MOREIRA NETO, Diogo de Figueiredo. O novo tribunal de contas: órgão protetor dos direitos fundamentais, p. 53. 
O que na realidade significa a assim chamada "separação de poderes", não é, nada mais nada menos, que o reconhecimento de que, por um lado, o Estado tem que cumprir determinadas funções - o problema técnico da divisão do trabalho e que, por outro, os destinatários do poder sejam beneficiados se estas funções forem realizadas por diferentes órgãos: a liberdade é o telos ideológico da teoria da separação de poderes. (...) O que, comumente, ainda que erroneamente, se costuma denominar como separação dos poderes estatais, é na verdade a distribuição de determinadas funções estatais a diferentes órgãos do Estado. $\mathrm{O}$ conceito de "poderes", apesar de profundamente enraizado, deve ser entendido neste contexto de uma maneira meramente figurativa. (...) é necessário ter bem claro que o princípio da necessária separação das funções estatais segundo seus diversos elementos substanciais e sua distribuição entre diferentes detentores, não é nem essencial para o exercício do poder político, nem se apresenta como uma verdade evidente e válida para todo tempo. O descobrimento ou invenção da teoria da separação de funções foi determinado pelo tempo e pelas circunstâncias como um protesto ideológico do liberalismo político contra o absolutismo monolítico da monarquia nos séculos XVII e XVIII. ${ }^{40}$

Alexandre Santos de Aragão ${ }^{41}$ colaciona importantes manifestações de notáveis juristas que dão suporte à idéia de relatividade das competências fixadas na Constituição, cujas transcrições parecem ser imprescindíveis neste trabalho, que trata exatamente de limites de competências e interesse público.

Também Miguel Reale, após denotar que a "função legislativa vai cada vez mais assumindo uma feição eminentemente técnica", afirma que "hoje em dia poucos se mantêm apegados ao dogma da divisão dos poderes, e a nossa história constitucional nos dá um exemplo característico das modificações sofridas pela doutrina, desde a sua primeira formulação clássica até a Constituição Federal vigente, na qual a divisão de poderes soberanos não tem mais o valor de um princípio essencialmente destinado à garantia das liberdades individuais, mas antes um valor pragmático de uma distribuição de funções, de uma simples aplicação da lei de divisão do trabalho no setor das atividades políticas".

Similar tratamento à separação dos poderes é dispensado por Reinhold Zippelius ao observar que "a 'clássica' divisão dos poderes assenta na distinção entre os âmbitos funcionais mais importantes do Estado. Os objetivos supremos da actividade do Estado devem ser permanentemente elaborados, revistos, harmonizados entre eles, e modificados na medida do necessário. (...) Desta maneira se projectam antecipadamente futuros modelos de ordenação e planos de acção relativos à política interna e externa”.

(...)

A "separação de poderes" deve ser atualmente encarada pelo prisma do pluralismo existente na sociedade, que "tem o significado de colocar perante várias instâncias da máquina estadual as reclamações ou o apoio de vozes diferentes. E assim resulta numa potenciação da divisão de poderes na organização interna do Estado, que ganha outra vez o valor duma divisão política. Só que, em vez da fórmula do século XIX de uma separação taxativa entre pretendentes ao poder, cada um com o seu veículo de expressão numa 'função' do Estado, vamos encontrar um sistema bem mais complexo e subtil (...) O pluralismo social vem assim integrar-se num quadro alargado de

40 LOEWENSTEIN, Karl. Teoria de la constitución. Tradução de Alfredo Gallego Anabitarte, p. 55-56, Ariel, 1986. Apud ARAGÃO, Alexandre Santos de. Agências reguladoras e a evolução do direito administrativo econômico. Rio de Janeiro: Forense, 2006, p. 372-373.

41 ARAGÃO, Alexandre Santos de. Agências reguladoras e a evolução do direito administrativo e econômico, p. 372-378. 
separação de poderes, e representa uma função positiva na organização dum estado moderno".

Especificamente sob o prisma da independência das entidades reguladoras, o Mestre de Valladolid, Javier García Roca, coloca como um dos principais aspectos da concepção contemporânea da separação dos poderes, ou, melhor dizendo, da divisão das funções estatais, o aparecimento de "novos órgãos auxiliares dos poderes supremos, muitos deles de relevância constitucional e não criados pelas leis, dotados de independência funcional no exercício de suas funções". Após citar como exemplo desta realidade os ombudsmen, os Tribunais de Contas e os Bancos Centrais, faz expressa referência aos "órgãos auxiliares e com perfis técnicos, mas igualmente independentes no exercício desta função do Governo".

(...)

Jean Dabin, com percuciência, asseverou: "Se idealmente fundada a distribuição de funções entre instituições ou órgãos distintos e independentes, ela não possui, todavia, senão um valor de meio, não de dogma, o que equivale a dizer que o princípio comporta uma série de exceções. As exceções serão justificadas, em primeiro lugar, toda vez que razões de interesse geral as imponham. A hipótese é bastante freqüente, mas sempre especial. Normalmente, por outro lado, do ponto de vista teórico, a solução derrogatória é aplicada ou pela história das instituições ou por considerações de oportunidade. (...) Para o bem ou para o mal, nos parece que o argumento da especialização, que constitui uma das razões do princípio dito da separação dos poderes, milita, na espécie, contra a separação".

Gérard Timsit, em colóquio realizado na Universidade de Paris I - PanthéonSorbonne sobre o tema, afirmou que o apego a antigos e, já de algum tempo, ultrapassados dogmas do Estado, inviabiliza qualquer elaboração teórica consistente acerca das entidades reguladoras independentes. Conclui asseverando que "o problema, em um Estado de Direito, não é o de absorver ou excluir, de alinhar ou de refutar estas novas instâncias ou instituições. O problema é antes de inventar novas formas e técnicas de controle sobre os novos tipos de autoridades".

A longa citação, que traz os preciosos ensinamentos de juristas de grande significação, fornece o material necessário para deixar firmada a superação da tripartição clássica do Poder, da divisão estanque de competências e do poder normativo atribuído a “órgãos auxiliares dos poderes supremos", notadamente, como enfatiza Javier García Roca, ${ }^{42}$ aos Tribunais de Contas e aos Bancos Centrais. Gérard Timsit, por sua vez, dá a exata solução para a questão proposta, e que coincide com a proposta apresentada neste trabalho: é preciso inventar novas formas e técnicas de controle para enfrentar, com segurança, dogmas que não mais se sustentam diante da complexidade da vida pública de nossos dias. Quando a Constituição trata das cláusulas pétreas, a expressão "separação dos Poderes" está se referindo somente às funções típicas de cada Poder, que são aquelas que garantem a autonomia e a independência de cada um deles.

A compatibilização do Direito com o social exige, ao mesmo tempo, o limite preciso do poder controlado pelo jurídico e a linha evanescente do político, que

42 ROCA, Javier García. Separación de poderes y disposiciones del ejecutivo con rango de ley: mayoria, minoria, controles. Cadernos de Direito Constitucional e Ciencia Política, São Paulo, RT, 27/15, 2009. 
constantemente se dissipa e torna a voltar profundamente transformada. Este trabalho não tem a pretensão de explorar as inúmeras medidas que se completariam, umas às outras, para amenizar a crise de legitimidade do Direito resultante do descalabro provocado por um sistema ineficiente que insistimos em preservar. Uma das soluções que ousamos sustentar é um controle popular realmente eficaz sobre os gastos públicos, mediante a participação do Tribunal de Contas, ainda na fase de discussão do plano plurianual, esclarecendo a sociedade e lhe oferecendo a oportunidade de se inteirar dos gastos acordados entre o Congresso e o governo antes da efetivação formal da partilha do orçamento. Nesse sentido, o Tribunal de Contas, verdadeiro poder neutral, deixa de ser somente o auxiliar dos Poderes constituídos para assumir, de modo especial, o papel de auxiliar da sociedade.

A separação de poderes tem em conta não só os limites de competência entre o Legislativo e o Executivo, mas uma completa avaliação sobre as posições que o Judiciário, o Tribunal de Contas, a Administração, as agências reguladoras, Banco Central, Conselho Monetário Nacional e todos os órgãos dotados de poder regulador ocupam, atualmente, na Constituição democrática brasileira. Com suporte na lição de Bruce Ackerman, pensamos que os três requisitos legitimadores de uma moderna divisão de poderes são: $a$ ) democracia, $b$ ) especialização e $c$ ) proteção e desenvolvimento dos direitos fundamentais. ${ }^{43}$ Esses três ideais não alcançam significação expressiva se considerados isoladamente. A eficiência, compreendida no segundo elemento, torna-se vazia de conteúdo se afastada de conteúdos finalísticos, ${ }^{44}$ já que a especialização não garante que leis democráticas sejam implementadas imparcialmente (democraticamente), assim como a ausência do terceiro ideal (direitos fundamentais) permite chegar à idéia de que democracia e profissionalismo podem servir a propósitos absolutistas. Por outro lado, especialização técnica e profissionalização são meios imprescindíveis para um governo ético e democrático, especialmente no que se refere à qualidade da informação pública.

Em conclusão, a tripartição de Poderes não atende mais às necessidades complexas do Estado moderno e exige uma harmônica manipulação de valores aparentemente conflitantes: técnica, política e ética.

43 ACKERMAN, Bruce. The new separation of powers. Harvard Law Review, n. 113, 2000, p. 634-638: "Separating power on behalf of what? The first ideal is democracy. In one way or another, separation may serve (or hinder) the project of popular self-government. The second ideal is professional competence. Democratic laws remain purely symbolic unless courts and bureaucracies can implement them in a relatively impartial way. The third ideal is the protection and enhancement of fundamental rights. Without these, democratic rule and professional administration can readily become engines of tyranny".

44 Ibid., p. 639. "The very idea of institutional 'efficiency' is completely empty unless it is linked to more substantive ends". 


\subsection{ADMINISTRAÇÃO: O PONTO FRACO DA DIVISÃO DE PODERES}

Não há discricionariedade nem na escolha nem na implantação de políticas públicas. A dimensão política da escolha pode ser sintetizada na opção racional e razoável que evita uma regressão ao infinito. É como se fosse, por assim dizer, um voto de Minerva para apartar um programa de outros igualmente bons. Essa opção não chega a ser discricionária, posto que vinculada às necessidades reais e aos critérios fixados pelo constituinte.

Na implantação do programa eleito, com agravadas razões, a discricionariedade do executor do orçamento deveria ser nenhuma. Ele poderia, em face de acontecimentos graves e imprevisíveis, utilizar a mesma "discricionariedade" empregada na escolha das políticas para justificar, na presença da situação excepcional, a escolha de como deveria ser feito o inevitável remanejamento das verbas do orçamento.

$\mathrm{O}$ que se quer deixar firmado, nesse caso, é a total inadmissibilidade de a Administração, na fase de execução das políticas, permitir que influências políticopartidárias interfiram no andamento dos projetos, seja submetendo-se aos interesses passageiros e ilegítimos dos governantes, seja deixando que as obras se transformem em "cabide" de empregos para apadrinhados do Poder. A experiência nos mostrou que as sociedades de economia mista e as empresas estatais não conseguiram cumprir os objetivos que inspiraram a sua criação em razão do mau uso da política. Por isso, seria insensato entregar a execução de políticas públicas ao próprio governo. É que a Administração Pública, na prática, é totalmente submissa ao poder político central. Essa é a exata razão pela qual as políticas são entregues a entidades estatais (autarquias especiais), colocadas, por lei, ao abrigo das influências do governo.

É lógico que essa independência é causadora de muitos problemas, mas a questão pode ser resolvida com o controle social das políticas, naturalmente, com a atuação esclarecedora do Tribunal de Contas. O que se quer evitar é que as escaramuças entre governo e agências sirvam de pretexto para fazer atuante, novamente, o mando político do chefe do Executivo. A questão tomou aspectos extremamente importantes com a recente crise protagonizada pelo governo e pela ANAC, exatamente quando o novo Ministro da Defesa assumiu a pasta. Em face do escudo protetor que envolvia a diretoria da ANAC, a crise acabou por movimentar os meios parlamentares para extinguir a independência das agências. Isso seria um retrocesso sem precedentes, pois a independência é exatamente a 
razão pela qual as agências foram criadas. Se isso chegar a acontecer, a Administração voltará a ter, novamente, o poder de exercitar a sua ineficiência e submissão política.

Por essa razão, é imprescindível fazer algumas observações sobre o calcanhar de Aquiles da Administração: não possuir lugar de destaque na divisão de poderes. Ela não tem sido considerada, em sua atuação própria, diversa da atuação do governo, porque, ao se conceber a divisão de poderes, a Administração foi totalmente ignorada. Quem exercia a Administração Pública era o Executivo. Até hoje é difícil avaliar qual a posição ocupada pela Administração Pública dentro do Poder Executivo. Uma coisa é certa, são bem diferentes em essência, não se podendo dizer que ela esteja submetida ao poder político: a Administração segue a orientação do governo, mas conserva sua identidade própria, e essa individualidade é que assegura a sua continuidade. O governo é passageiro, a Administração Pública é permanente, embora tenha de se adequar à opção política imprimida pelo governante.

Desse ponto de vista, fica difícil reconhecer a atividade política dos governantes eleitos pelo povo e a atividade burocrática da Administração Pública. Os fins perseguidos não são os mesmos. Em verdade, a Administração Pública deve ser a necessária interface entre o poder e o povo:

\footnotetext{
A Administração desempenha funções de output, isto é, de execução de políticas decididas por órgãos de representação política. Esse caráter executivo traz algumas implicações, como a "exaltação do valor da neutralidade administrativa". ${ }^{45}$
}

Em vista desse ensinamento, inspirado em Sorace e Lorenza Carlassare, perguntase: qual a medida da neutralidade da Administração Pública, considerando que a idéia de burocracia independe dos titulares do poder, que são passageiros? Como se deve entender a idéia de caráter técnico e não-político da atividade administrativa? É inegável que a Administração Pública é duradoura e não faz tábula rasa das administrações passadas, pois seria ridículo pensar que novas administrações são inauguradas com a posse de cada governante eleito pelo povo. Não há servilismo e impessoalidade na Administração Pública, que não pode conduzir somente a vontade política de grupos periodicamente encastelados no poder.

Por outro lado, é inegável que a ação administrativa deve refletir a estratégia do chefe do Executivo e de seus secretários. Percebe-se que há grupos distintos dentro dos

45 MEDAUAR, Odete. O direito administrativo em evolução. 2. ed. São Paulo: RT, 2003, p. 136. 
órgãos que compõem a Administração: de um lado, os servidores que exercem funções de confiança (cada vez mais numerosos), para implantar o modelo político do governante, e que, geralmente, saem da Administração juntamente com os integrantes do poder político, e, de outro, os funcionários de carreira, que servem a inúmeros governantes durante a sua vida funcional e dão sequiência a políticas de Estado de duração extremamente longa.

Por outro lado, algumas entidades que fazem parte da Administração, como as de Direito Privado e as agências reguladoras, devem apresentar maior independência dos interesses políticos sazonais dos governantes, por sua própria estrutura, diversa da dos órgãos que compõem a Administração Direta. A questão é como avaliar o demasiado e o muito pouco. Qual o grau de autonomia que a Administração pode ter em relação ao projeto de cada governo? Afinal, o chefe do Executivo é eleito para promover os projetos políticos, sociais e econômicos expostos aos eleitores durante a campanha eleitoral.

O princípio da hierarquia também dificulta a conduta imparcial de uma Administração duradoura, que não se extingue e recomeça a cada governo como uma fênix. É difícil saber o que é insubordinação e o que pretende resguardar a Administração de interesses de indivíduos, partidos ou grupos. Exatamente para resguardar a possibilidade de uma conduta moralmente irrepreensível é que foi criada a estabilidade do servidor efetivo. Alega-se também que, como a Administração Pública não tem autonomia ideológica, está presa ao poder político dominante. Caso contrário, ela seria, eventualmente, crítica da filosofia do poder político. Exemplo dessa limitação foi o plano econômico do Governo Collor, que congelou os haveres de todo o povo. Embora essa política se mostrasse inconstitucional, os funcionários de carreira graduados não puderam se opor ao plano. Nesse sentido, não era apenas um plano político, mas um plano econômico inconstitucional. Entretanto, as demissões dos técnicos que se colocassem contra o plano seriam absolutamente justificadas.

As respostas a essas questões não decorrem, objetivamente, do sistema; porém é certo que a idéia de neutralidade permeia o modelo político-administrativo moderno. É uma situação que todos compreendem e com a qual concordam, mas que não se sabe como precisar objetivamente. Alguma autonomia deve revestir a Administração Pública, pois ela não pode ser a extensão incondicional da vontade dos governantes. Talvez seja necessário apartar questões técnicas de projetos políticos, mas é evidente que ambos se tangenciam e se confundem em muitos pontos. Ademais, a atividade administrativa também é uma questão política. 
O problema tem a ver com o sistema da tripartição dos Poderes e com o reconhecimento de que a Administração Pública não se confunde com o Executivo. Há uma certeza, a solução não pode ser encontrada em análises pouco profundas e conservadoras. Deve decorrer da pluralidade das fontes e dos sujeitos envolvidos na relação Estado-sociedade e de interpretação que não considere o bem comum e o coletivo como a vontade do Estado, pois o interesse público é a soma dos interesses individuais, extraído, caso a caso, conforme a época, o lugar e o desenvolvimento econômico-social da parcela da sociedade relacionada com a questão focada. Com a derruição dos grandes sistemas normativos e da unidade da sociedade, microssistemas e realidades regionais conduzem a soluções específicas, que não estão prontas para uso, ao contrário, devem ser artesanalmente construídas na presença do caso concreto. Nesse panorama, ousamos dizer que a superação dos grandes sistemas alcança até mesmo a Constituição dirigente, que deve ser interpretada em harmonia com todo o sistema jurídico e moral. A indiscutível superioridade da Constituição não impede o mútuo relacionamento que deve apresentar com todo o Direito. Nesse exato sentido, ponto e contraponto provocam uma intensa harmonia entre normas de hierarquias diversas, já que seria inconcebível que a superioridade do sistema constitucional provocasse o seu isolamento. $\mathrm{O}$ efeito, então, seria o oposto do desejado.

O primeiro ponto de perplexidade é a ambigüidade da idéia de Administração executora e neutra, a um só tempo, se considerarmos a discricionariedade vinculada aos princípios. Se a Administração Pública está vinculada aos princípios, não se pode falar em submissão ao poder político dirigente. Parece fora de dúvida que a burocracia age dentro da organização estatal e que funcionários de carreira exercem efetiva influência sobre a conduta das autoridades da cúpula do Executivo. Entretanto, se é possível focalizar o problema e dar a solução óbvia que é a da razoabilidade da separação da Administração, na prática, parece ser extremamente complicado encontrar o ponto ideal de independência existente entre a Administração Pública, o poder político exercido pelo chefe do Executivo e todos os cargos de confiança que são preenchidos exatamente para fazer valer a vontade dos governantes. É inegável que, dentro da mesma Administração, convivem personagens vocacionados para finalidades absolutamente diferentes.

Os mais diversos vetores apontam para caminhos opostos, freqüentemente relacionados com a continuidade da Administração Pública e interesses ocasionais do partido político da situação. Demonstração clara dessa torre de Babel é o poder normativo exercido por funcionários de carreira (não-eleitos). Como eles fazem a intermediação entre 
o Estado e o povo, é inegável a força normativa de suas decisões. Na complexidade das atividades do Estado, nas relações com a sociedade, em sua maioria esmagadora as decisões não exigem participação direta das cúpulas político-partidárias, pois são tomadas em todos os níveis administrativos por servidores que, autonomamente, tomam todas as microdecisões cotidianas.

Não há fórmula mágica para resolver as questões formuladas sobre as relações existentes entre o poder político e a Administração Pública. O fato é que não há administração sem política, nem política sem administração, portanto, a separação proposta é ilusória e aparente. A questão resume-se na busca de uma equilibrada relação entre a orientação política e a imparcialidade. Como não se pode apartar política de administração, cabe ao Direito Administrativo a tarefa de manter esse equilíbrio e de buscar novos meios para permitir a coexistência da política com a técnica dentro da Administração. Enquanto isso não acontece, há possibilidades que têm sido bem eficientes nos outros países, como a criação de agências reguladoras.

Na Itália, há posições doutrinárias para a liberalização da Administração Pública do poder político, superando-se a idéia da Administração escondida nas dobras do Executivo. A Administração é pública porque presta serviços à generalidade dos cidadãos, não por estar ligada ao governo. A Constituição brasileira, a exemplo de muitos outros Estados, não impede esse entendimento, pois contém título específico para a organização do Estado, em capítulo próprio, sem ligação direta com o Poder Executivo.

Essa idéia pode ter diversos desdobramentos importantes, como a extinção dos recursos hierárquicos, a avocação, o reconhecimento de que o Estado não é obrigado a recorrer sempre nas decisões judiciais contrárias e na extinção dos recursos ex officio. Da mesma forma, a Administração não precisaria contender com o particular em questões totalmente superadas, nas quais a Administração, mesmo sem nenhuma convicção, colocase contra os interesses dos cidadãos. Administrar seria, então, a melhor maneira de aplicar a lei para concretização de uma Justiça mais próxima do ideal.

O tema das relações entre política e administração se traduz na contraposição entre governo e Administração. Deve-se distingui-los, não apartá-los. Ambos compõem a idéia de Poder Executivo, mas devem ser vistos de maneira que a transitoriedade do poder não impeça a continuidade da Administração.

Administração e governo, em conclusão, existem de modo separado, mas devem conviver, sem servilismo e sem a presença de uma administração somente tecnocrática. Essa comunicação permite ao governo imprimir políticas públicas sem olvidar que a 
Administração Pública, antes de seguir o modelo ditado pelo poder político, está submetida à lei e ao Direito. Impede-se, com isso, que as decisões tomadas em nome da coletividade sejam o reflexo do interesse do governo, e não dos cidadãos ou da sociedade.

O controle social, na dimensão preconizada nesta tese, desfaz o diálogo improdutivo e tendencioso entre governo e Administração e introduz os mais diversos setores representativos da sociedade nesse desejável debate plurirrelacionado.

\subsection{INADEQUAÇÃO DO SISTEMA NORMATIVO E DOS INSTRUMENTOS DE CONTROLE DO PODER PÚBLICO}

A sedimentação do Estado Social determinou uma substancial transformação na relação entre Estado e sociedade. Antes disso, esperava-se do Estado uma postura basicamente negativa, ou seja, de não-agressão aos direitos do cidadão. Como se percebe, seria fácil conceber um Estado, nessa concepção, com poderes tripartidos. Tudo se ajustava perfeitamente, por isso, seria um verdadeiro sacrilégio falar em poderes normativos delegados ou autônomos. O Executivo, como mero executor da lei posta pelo Legislativo, tornava a tarefa do Judiciário, em tese, relativamente simples. Bastava conferir o ato administrativo com a lei (genericamente falando) que a ação seria legal ou ilegal, tertius non datur.

Com a assunção do Estado Social, foi necessária uma posição mais positiva que negativa do Poder Público. A responsabilidade pelo bem comum, as condições de acesso à cidadania social, a responsabilidade pela dignidade, por condições de vida do ser humano e pela economia interna e externa, com todas as suas implicações, como emprego e garantia de renda suficiente para o trabalhador, são tarefas que exigem decisões em tempo real, na flagrância dos fatos. Com a adoção de políticas públicas e uma Constituição marcadamente dirigente, o Executivo passou a assumir um lugar de destaque na ordem econômico-social, a ponto de ser responsável pela maioria esmagadora das normas editadas. O Legislativo manteve o impreciso controle das normas gerais e o delineamento geral das políticas, mas coube ao Executivo e às agências reguladoras, autarquias independentes do jugo do poder central, a concreta efetivação das demandas públicas e do complexo sistema financeiro e econômico, absolutamente dependente da economia mundial.

Um fato ocorrido no exterior, como uma crise político-econômica ou uma simples oscilação na Bolsa de outro Estado, requer uma resposta interna imediata, contada em horas, ou mesmo minutos, não em dias. Seria difícil impedir graves ocorrências no 
mercado interno, como o desabastecimento, sem conferir ao Executivo poderes normativos para tomar as urgentes medidas necessárias, inclusive para prescrever penalidades administrativas indispensáveis à regulação do mercado. Cânones do Direito são, em decorrência das novas atribuições conferidas ao administrador, literalmente derruídos. A crise econômica de 2008 demonstrou, na prática, a correção dessas observações. Os poderes atribuídos ao Banco Central e à área econômica do governo demonstram a importância do peso atribuído ao "novo" poder normativo do Executivo. Relembre-se, a respeito, a falta de apoio político e as severas críticas endereçadas ao Congresso norteamericano quando tentou se opor ao plano das autoridades governamentais para a liberação de US\$ 700 bilhões para enfrentar a crise. Ficou claro, nesse episódio, que não só a sociedade norte-americana mas o mundo inteiro não negou competência ao legislador para conduzir a essência das medidas de emergência tomadas no estado de exceção econômica prolongada em que se encontram os Estados Unidos. Aliás, convém lembrar que a crise gestada em solo norte-americano estendeu-se, em tempo real, a todo o mundo e tornou o estado de exceção um regime compartilhado por bilhões de pessoas.

Com esses fatos, algo aconteceu com o Direito posto. A hermenêutica constitucional e o estatuto processual que lhe dá vida, o Direito Administrativo, assim como todo o Direito Público, não se ajustam mais ao novo modelo de emergências prolongadas. Em face do desajuste do Direito com a realidade, com surpresa, passa-se a admitir a existência de um Direito Administrativo paralelo e até de uma Constituição paralela. Não se pode mais sustentar que o regulamento só pode ser "executivo" e que ele não pode inovar, de maneira absoluta, o Direito. Afinal, quem dá os fins, dá os meios, mas essa inovação não pode transcender certos limites do princípio da legalidade. Em verdade, não há crise alguma na legalidade. Ao contrário, sem lastro em lei, não se pode falar em competência normativa, mesmo porque qualquer competência só pode ser atribuída por meio de lei formal.

Explica-se. Como anota Eros Grau, as normas de Direito Econômico devem ser consideradas diferenciadas em relação a outros ramos do Direito, justamente porque são dotadas de caráter conjuntural, o que determina a sua inevitável flexibilidade e dinamismo. Além disso, por serem o resultado de elaboração prospectiva, e não retrospectiva, mostram-se com uma verdadeira capacidade normativa de conjuntura. A capacidade normativa de conjuntura visa, em última análise, conferir resposta adequada à exigência de produção imediata e urgente de textos normativos que as flutuações da conjuntura econômica e o imobilismo do Legislativo impõem. Assim, segundo o Ministro, "o caminho 
está a viabilizar o controle desse exercício normativo e por isso deve-se criticar as posições radicais, no sentido de que a função normativa das agências seria inconstitucional e pronto. O melhor é encontrar meios para viabilizar o controle" ${ }^{, 46}$ (grifo nosso).

É evidente que esses meios de controle não podem ser os mesmos utilizados no Direito Administrativo clássico. O novo poder regulador atribuído às agências reguladoras e a outras entidades, como o Tribunal de Contas e o Banco Central, exige novos métodos hermenêuticos e nova visão sobre a aplicação e a efetividade dos freios e contrapesos exercidos entre si pelos Poderes do Estado. É que não é possível fazer mudanças relevantes em sistemas jurídicos e políticos ultrapassados sem a correspondente inovação nos métodos de controle externo e o agravado fortalecimento do princípio da legalidade.

Com desânimo, a comunidade jurídica e o sistema de controle dos atos do Poder Público, notadamente o Judiciário, procuram atender às necessidades dos administrados descontentes com a aparente deslegalização do Direito, mas, de maneira inglória, enfrentam as novas situações com a mesma concepção do Direito ultrapassado. No embate entre segurança e justiça, nenhum dos valores é prestigiado, porque só seriam minimamente observados se a certeza da segurança absoluta fosse abandonada. No entanto, em um sistema jurídico concebido para não transigir no item segurança, a ponto de preferir eternizar injustiças para não eternizar conflitos, não se poderia esperar mais do que a satisfação com a certeza garantida, ainda que para isso o quadrado ficasse redondo e o branco se tornasse preto.

Com o controle insuficiente do Poder Público e diante do claro desajuste do sistema normativo, torna-se inevitável a crise na credibilidade das promessas constitucionais. $\mathrm{O}$ Judiciário, ante o respeito que devota à separação de poderes e à legalidade, até há pouco tempo recusava-se a enfrentar o mérito de decisões que exigissem a sua mínima politização. Isso, no entanto, para o Poder mais austero e conservador do Estado, é tarefa bastante problemática, porque os outros Poderes criam as normas, mas não o direito. A neutralidade do Poder Judiciário é o símbolo da prudência, bom senso e reserva moral, mas determina, para seu horror, a abdicação de uma Justiça eficaz. Sucede que essa neutralidade refere-se às competências típicas de cada Poder, como se verá no tópico destinado à verificação de suas atribuições.

Pode-se ver, nessas questões formuladas sobre a atuação do Poder Judiciário, mais qualidades que defeitos e mais admiração que crítica. Talvez uma postura diferente

46 Posição manifestada em sua palestra no XII Congresso Brasileiro e II Congresso Sul-Americano de Direito Administrativo. 
pudesse ocasionar um desastre e uma anarquia sem precedentes. Evidentemente, o Judiciário não é responsável direto pela absoluta ineficácia da Justiça, mas o problema da inadequação existe, sejam quais forem as causas, e é só isso que se quer demonstrar. É que o Direito - especialmente o Direito Administrativo e o Direito Processual - está circunscrito a um esquema positivado totalmente expurgado do processo político, e isso é fatal para a legitimação do Direito Público. Então, avulta a necessidade de controlar o Poder Público de outras maneiras, sobretudo porque só uma infinita parte dos administrados tem condições econômicas para buscar (e aguardar) o tardonho auxílio dos Tribunais.

Não obstante essas dificuldades, adiante será proposta uma nova opção que se abre ao Judiciário, experimentada com sucesso em alguns países: a participação desse Poder, tradicionalmente neutral, na complexa cadeia de atos que conformam uma nova política pública. Antes, porém, por simples questão de método, trataremos da hermenêutica constitucional e das mutações constitucionais. Em um crescendo, acreditamos ser preferível encerrar o capítulo com algumas observações pontuais sobre interpretação e atualização da mensagem constitucional para depois desenvolver o difícil tema do estado de exceção permanente e seus efeitos sobre o princípio da legalidade.

\subsection{HERMENÊUTICA CONSTITUCIONAL. "MUTAÇÃO CONSTITUCIONAL". FUNÇÕES DE BLOQUEIO, DE RESGUARDO E DE PROGRAMA}

A norma constitucional pode ser entendida em si mesma, no sentido abstrato de seu texto, como ensina Fábio Konder Comparato, mas deve-se reconhecer,

\footnotetext{
(...) como regra geral, que as palavras de um texto constitucional hão de ter um sentido efetivo não significa que, em determinado caso concreto, o julgador deva forçar uma solução contra o resultado evidente do trabalho de interpretação, à luz das circunstâncias de fato da causa. (...) As Constituições contemporâneas já não são simples distribuidoras de competência, organizando o Estado como entidade neutra e arbitral perante os conflitos da sociedade civil. Muito ao contrário, elas se apresentam como imposições de finalidades coletivas, como programas de transformação ou aperfeiçoamento social, vinculantes tanto para os órgãos públicos quanto para as pessoas privadas. Assim, na Constituição brasileira de 1988 os objetivos fundamentais, expostos em seu art. $3^{\circ}$, dirigem e orientam a vida nacional. São eles, pois, os critérios supremos de inteligência do texto constitucional e da interpretação concreta dos problemas a serem solucionados. ${ }^{47}$
}

47 COMPARATO, Fábio Konder. Direito público: estudos e pareceres. São Paulo: Saraiva, 1996, p. 76-77. 
Como ensina Canotilho, o Direito Constitucional encerra um compromisso permanentemente renovado. Néviton Guedes, em seu prefácio para a obra Canotilho e a Constituição Dirigente, recorda as oportunas lições do Justice Brennan e de Dieter Grimm:

\begin{abstract}
A sabedoria da Constituição (...) não reside em nenhuma opinião estática que se havia tido num mundo que (já) esteja morto e (já) se foi, mas (sim) na adaptabilidade dos seus grandes princípios para fazer frente a problemas correntes e a necessidades atuais (e) A bondade das constituições não se deixa determinar de forma absoluta e universal, mas apenas segundo um contexto histórico concreto. (...) O que era razoável no passado pode perder seus objetivos no presente. ${ }^{48}$
\end{abstract}

Admitindo-se que ainda engatinhamos no efetivo cumprimento das opções políticas inscritas em nossa Constituição, não há como afastar que as Constituições dirigentes, que existirão enquanto forem historicamente necessárias, devem constantemente ajustar-se a esse processo:

Penso que o desafio da Constituição dirigente não é o de torná-la rígida, devendo
admitir-se que ela pode ser modulada de outra maneira, de acordo com as
evoluções e as inovações. (...) É a tentativa de salvar a personalidade de normas
constitucionais através de instrumentos mais sofisticados, como a
hermenêutica. 49

A Constituição Federal é um espelho do presente, uma previsão do futuro e, especialmente, uma ordem a ser desenvolvida, exatamente porque não leva em conta uma ordem natural, mas uma ordem criada pelo homem, segundo as aspirações que irão revelarse ao sujeito histórico em um futuro próximo ou distante. Essa modulação, como é evidente, só poderá ser reconhecida pelo legislador ou pelo intérprete no momento oportuno, de maneira a conformar a idéia de Constituição evolutiva, cognitivamente aberta.

Ora, se a Constituição-garantia cedeu passo à Constituição-programa, não pode mais ser concebida somente como instrumento organizatório, demarcador de competências e atribuições abstratas, como asseverou Fábio Comparato na citação feita no início deste item; ao revés, exige que essas normas sejam utilizadas para uma efetiva concreção de programas e fins que a vida real reclama. A Constituição propõe metas abstratas que devem, coativamente, ser realizadas pelo legislador infraconstitucional e pela Administração, no entanto, ela é mais que o momento captado pelo constituinte, pois

48 GUEDES, Néviton. In: COUTINHO, Jacinto Nelson de Miranda (Org.). Canotilho e a constituição dirigente. 2. ed. Rio de Janeiro: Renovar, 2005, p. 1 e 11.

49 CANOTILHO, José Joaquim Gomes. In: COUTINHO, Jacinto Nelson de Miranda (Org.). Canotilho e a constituição dirigente. 2. ed. Rio de Janeiro: Renovar, 2005, p. 41 e 43. 
encerra a forma como as necessidades futuras poderão ser atendidas. A ordem que deve ser criada projeta-se para o futuro e para as próximas gerações, por isso deve ser continuamente ajustada à realidade. Não se confunde com as normas programáticas, que apenas indicam um caminho a seguir.

Essas metas abstratas obrigatórias para o legislador infraconstitucional e para a Administração são normas-objetivo, que não admitem a livre disposição nem o remanejamento de verbas destinadas ao prosseguimento das políticas. A respeito, podemos invocar a lúcida observação de Eros Grau:

A existência de uma norma-objetivo no bojo de uma parcela do ordenamento
jurídico vincula o intérprete na interpretação de suas normas de conduta e de
organização, de modo que não poderá ser tida como aceitável hermenêutica que
não seja estritamente coerente com a realização dos fins nela inscritos.

Isso acontece porque uma Constituição dirigente como a nossa não procura só garantir o presente, mas programar o futuro.

A interpretação de legitimação das aspirações sociais de que se fala opera um outro tipo de subsunção, muito diferente da costumeira adequação de um fato qualquer à norma. O constitucionalismo contemporâneo espera que o Estado exerça funções não só de bloqueio como de legitimação. Embora as linhas gerais dos programas e os limites objetivos do juízo de oportunidade e conveniência pertençam ao legislador, é intuitivo que na função de legitimação a relação entre meios e fins incumbe ao intérprete. Na função de bloqueio o Estado deve obediência irrestrita ao princípio da legalidade, por isso que tanto os meios como os fins são dados pelo legislador, cabendo ao intérprete somente encontrar os meios disponíveis que melhor satisfaçam os fins dados. Na função de resguardo, no entanto, para alcançar fins objetivados, admite-se que a interpretação legitime os meios. Contudo, se a função puder ser entendida como de programa, a interpretação legitimará os próprios fins, para que os meios possam ser escolhidos pelo legislador ou, caso não existam, possam ser criados pelo intérprete.

Tercio Sampaio Ferraz explica com maestria essa questão:

$\mathrm{Na}$ interpretação de legitimação, a unidade de sentido é, basicamente, teleológica. Mas a teleologia põe-se a serviço da modificação da própria realidade sobre a qual incide. A função eficacial preponderante é de resguardo. Presume-se uma competência legislativa positivamente vinculada. A interpretação legitima os meios, alterando a realidade, de modo que os fins positivamente vinculados possam ser alcançados. Se a função eficacial

50 GRAU, Eros Roberto. Notas sobre a noção de norma-objetivo. Revista de Direito Público, São Paulo, RT, v. 71, p. 137-152, 1984. 
preponderante é de programa, presume-se uma competência negativamente vinculada. A interpretação legitima os fins, de modo que a realidade seja alterada, a fim de que os meios, se não existentes, possam ser adequadamente criados pelo legislador (...) Cabe ao intérprete uma articulação legitimadora dos próprios fins, a partir do que se revelarão os meios adequados. ${ }^{51}$

Essas constatações refogem aos meios ortodoxos de controle, pois, se é pelo intérprete que os fins e meios podem ser moldados, conforme um dado momento histórico, torna-se extremamente complicado entender que um único intérprete - ainda que o oficial - ou um pequeno círculo de intérpretes ostentem o poder de transformar a realidade. A idéia é, em verdade, alterar a realidade, mas como conciliar efetividade com segurança? O Estado investido na função de legitimação pressupõe uma Constituição que exige mudanças, mas essas alterações são capazes, em tese, de desestabilizar uma contradição aceitável entre a Constituição formal e a Constituição real. É inevitável, nesse caso, a lembrança da Constituição de Weimar, que acabou legitimando a ascensão de Hitler ao poder ao não ser ostensivamente desrespeitada, pois aos alemães confortava a idéia de que os nazistas haviam chegado ao poder por vias constitucionais, e não por um golpe de Estado.

A necessidade de buscar novos paradigmas para lidar com figuras jurídicas tão diferentes como as agências reguladoras, com a nova visão do princípio da legalidade e com o poder normativo que era preciso outorgar ao Executivo, conseqüência direta do Estado regulador que emergia, exigia ou uma drástica reforma constitucional, o que certamente seria um risco para a segurança jurídica, ou uma nova interpretação da Constituição, para adequá-la às novas exigências. Karl Loewenstein chama esta técnica de mutação constitucional, que conserva o texto intacto, mas provoca uma releitura da Constituição. Essa releitura permitiu a implantação das agências reguladoras independentes e um alcance verdadeiramente revolucionário para os princípios da legalidade e da eficiência (art. 37 da CF).

Tercio Sampaio Ferraz, sobre esse mesmo tema, ensina que:

Como assinala Karl Loewenstein (1970, p. 165 e ss.), há uma importante
diferença entre o processo de reforma constitucional conforme as regras
previstas para o exercício do poder derivado e a chamada "mutação
constitucional", caso em que se produz uma transformação na real configuração
do poder político, da estrutura social e do equilíbrio de interesses, sem que isso
se reflita no texto da Constituição, que, de resto, permanece intacto. A
consequiência dessa segunda hipótese é significativa, pois será possível dizer que,
por força da "mutação constitucional", a norma textual ou se distancia da

51 FERRAZ JR., Tercio Sampaio. Direito constitucional, p. 17. 
realidade (problema de sua eficácia) ou mesmo "é posta fora de vigor" (problema de validade). Ou, como diz Canotilho (1995, p. 231), "muda o sentido sem mudar o texto". ${ }^{2}$

Canotilho está se referindo a uma mutação lógica, aceita por todos, não a construções que variam conforme necessidades e interesses. O fragmento de Heráclito "entramos e não entramos duas vezes no mesmo rio" proporciona duas interpretações lógicas e racionais: entramos no mesmo rio, se o identificarmos por suas margens; mas nunca entramos no mesmo rio, se a identificação for feita pelas águas que nele correm. Pode-se entender também, se recorrermos a uma interpretação metafórica, que só entramos duas vezes no mesmo rio se as condições de fato forem exatamente iguais, ou o nosso estado psíquico e emocional for o mesmo. Mas a sociedade só entra duas vezes no mesmo rio se a interpretação aceita como a mais lógica e racional for admitida pela maioria.

Lembremos-nos de um pensamento de Pascal (Pensées): "Mesmo quando a palavra de Deus, que é veraz, é falsa literalmente, é verdadeira espiritualmente". Se o sentido literal não evoca mais o mesmo significado inicial, é preciso fazer uma leitura atual para preservar o mesmo sentido original. Muda a interpretação, mas não o sentido. A exigência de uma releitura de um texto constitucional segue o mesmo raciocínio. Precisamente para preservar os valores prestigiados pela separação de poderes e pela distribuição de competências - o telos da separação de poderes e da distribuição de competências, segundo Loewenstein, é a liberdade - é que não se pode mais acreditar, como antes, que a Constituição não admite nenhuma interpretação capaz de mudar o sentido literal.

Pode-se comparar a Constituição ao Ulisses de Joyce, que introduziu o "romance aberto". Para preservá-la, afasta-se de seu sentido literal e reclama a integração do intérprete para validar a sua mensagem. Exemplo clássico dessa assertiva é o dispositivo que o Congresso norte-americano introduziu no Código dos Estados Unidos em 1864, limitando a US\$ 10 a taxa que um veterano podia pagar a um advogado para intentar uma ação de benefícios. O pressuposto que permitiu a prescrição era o de que US\$ 10 podiam comprar, com dignidade, os serviços profissionais de um advogado. Se nessa época tal valor fosse contestado na Justiça, não poderia o juiz discordar do valor estabelecido, justamente por se tratar de um pressuposto de valor, porém, mais de um século de inflação não permitiria que US\$10 pudessem retribuir os honorários de um advogado em causa semelhante, por exemplo, a de um mutilado da guerra do Iraque. A simples passagem do

52 FERRAZ JR., Tercio Sampaio. Direito constitucional, p. 21. 
tempo tornou errôneo o pressuposto de fato, o que obrigaria o juiz a entender US\$ 10 como sendo o valor que atualmente compra o que era comprado em 1864.

Se a Justiça interpretasse que a quantia de US\$ 10 vale, hoje, US\$3.000, com um critério de simples atualização do seu valor de compra, corrigiria um pressuposto de valor e, portanto, alteraria o texto, o que não se pode admitir. Mas, se, em vez de restabelecer o padrão de compra, buscar descobrir quanto custa os serviços de advogado para o mesmo trabalho, só estará tentando encontrar equivalentes de significados entre contextos. Deve-se perceber que a diferença não é tão sutil assim, pois a simples atualização dos US\$ 10 não poderia ser feita fora do contexto original, sem considerar o motivo pelo qual a emenda foi introduzida na Constituição, e que era permitir uma digna representação judicial de excombatentes desprovidos de recursos. O texto não seria alterado em sua substância, ao contrário, apenas seria preservado. É essa busca de equivalentes de significados entre contextos que torna possível entender a Constituição (e a separação de poderes) como uma obra aberta, sem torná-la flexível.

A evocação feita ao Ulisses tem essa precisa intenção. Muitas vezes, a norma constitucional não reclama a atuação complementar do legislador infraconstitucional, mas do próprio intérprete. Pensamos que aí reside a necessidade de entender a norma positivada em sua dimensão própria, isto é, de plena integração entre fatos e norma. Se fatos, iniludivelmente, compõem a norma e se a lei é editada para a normalidade das coisas, fatos excepcionais, permanentes ou não, impõem interpretação e aplicação especiais. Exatamente aí entra a atividade criadora do intérprete para legitimar a norma que não se ajuste aos fatos cambiantes.

Nesse passo, entendemos já ser hora de tratar de um assunto importantíssimo, não obstante a persistente omissão de grande parte da doutrina, que insiste em desconhecer a real existência de um permanente estado de exceção que envolve grande parte dos Estados. Preferimos, talvez pela insegurança que o tema provoca, continuar vendo a exceção atual como a exceção da exceção anterior, e assim por diante. Essa é uma maneira de pensar que os desdobramentos das exceções, embora prolongados, não eliminam a existência de uma normalidade perene. A crise, por esse ângulo, é somente o dramático efeito da ausência de medidas destinadas a combatê-la. Nunca chegamos a reconhecê-la como permanente, isto é, que a normalidade tenha cedido espaço e necessite conviver com a exceção. Em verdade, a normalidade, ao incorporar o excepcional, tornou-se a normalidade possível, não por um momentâneo intervalo de tempo, enquanto aguardamos as medidas que 
poderiam eliminá-la, mas de forma duradoura. É essa, em síntese, a raiz das ordens paralelas tão bem exploradas por Gordillo. ${ }^{53}$

53 GORDILLO, Agustín Alberto. La administración paralela. Civitas: Madrid, 1995. 


\title{
ESTADO DE EXCEÇÃO PERMANENTE E POLICENTRISMO DA ECONOMIA GLOBALIZADA
}

\author{
José Eduardo Faria manifesta-se da seguinte maneira sobre a inadequação do \\ Direito Positivo editado pelo Estado-nação para regular as situações extremamente \\ dinâmicas decorrentes da globalização de interesses supra-estatais:
}

Como o Estado não pode deixar muitas dessas ações, fatos, situações e casos sem algum tipo de controle, ele se vê obrigado a editar normas ad hoc para casos altamente especializados. E quanto maior a sua produção normativa nessa linha, mais seu direito positivo perde organicidade e racionalidade sistêmica, dada sua pretensão de abarcar uma intrincada e por vezes contraditória pluralidade de interesses e comportamentos altamente particularísticos.

(...)

O Estado-nação se encontra diante de um impasse. Por um lado, já não consegue mais disciplinar e regular sua sociedade e sua economia exclusivamente por meio de seus instrumentos jurídicos tradicionais. Com as intrincadas tramas e entrelaçamentos promovidos pelos diferentes setores econômicos no âmbito dos mercados transnacionalizados, seu ordenamento jurídico, suas instituições judiciais têm alcance cada vez mais reduzido e operacionalidade cada vez mais limitada.

(...)

Essa soberania compulsoriamente partilhada, sob pena de acabar ficando à margem da economia globalizada, tem obrigado o Estado-nação a rever sua política legislativa, a reformular a estrutura de seu direito positivo e a redimensionar a jurisdição de suas instituições judiciais amplas e ambiciosas estratégias de desregulamentação, deslegalização e desconstitucionalização, implementadas paralelamente à promoção da ruptura dos monopólios públicos. A noção dessa estratégia é justificada, entre outros fatores, por uma espécie de cálculo de custo/benefício feito pelos dirigentes e pelos legisladores. Sem ter como ampliar a complexidade de seu ordenamento jurídico e de seu aparato judicial em nível equivalente de complexidade e diferenciação funcional dos diferentes sistemas sócio-econômicos, eles passam a agir pragmaticamente.

(...)

Nesse cenário, o que resta do direito positivo forjado pelo Estado-nação com base no dogma da completude, no princípio da coerência, no postulado da inexistência de lacunas e de antinomias e nos primados da previsibilidade, da certeza e da segurança? ${ }^{54}$

54 FARIA, José Eduardo. Declaração Universal dos Direitos Humanos: um cinqüentenário à luz da globalização econômica. Disponível em: <http://www.cjf.jus.br/revista/numero6/artigo5.htm>. Acesso em: 25 dez. 2008. 
O questionamento feito ao final da citação é bastante significativo, já que nem mesmo a soberania compartilhada apresenta o mesmo aspecto idealizado de antes. Quando a expressão foi cunhada, podia-se perceber sob as vestes do compartilhamento uma consensualidade multilateral que não existe mais, pelo menos não na proporção anteriormente imaginada. É que o ajuste, em grande parte, não é feito em relação a dois ou mais Estados soberanos. O Direito Positivo do Estado-nação vem sendo progressivamente internacionalizado pela Lex mercatoria, pelo Direito da Produção, pelas regras impostas por organismos multilaterais e pelas normas produzidas por setores privados nacionais, que tendem a obedecer a normas privadas não escritas mas toleradas pelo Estado moderno, na medida em que, conscientemente, adotam posições favoráveis à desregulamentação da economia.

O Estado constitucional deixa de ser, com esse processo de desregulamentação e deslegalização - José Eduardo Faria refere-se até a uma desconstitucionalização -, o modelo perfeito de engenharia social do século XIX e passa a participar de uma complexa rede de sistemas e subsistemas socioeconômicos, internos e externos, públicos e privados, escritos e costumeiros.

\footnotetext{
Assumindo assim a forma de redes, esses microssistemas legais e essas cadeias normativas se caracterizam pela extrema multiplicidade e heterogeneidade de suas regras; pela flagrante provisoriedade e mutabilidade de suas engrenagens normativas, pelo acolhimento de uma pluralidade de pretensões contraditórias e muitas vezes excludentes. ${ }^{55}$
}

Com essa multiplicidade de fontes, às quais o Estado possui pouca ou nenhuma capacidade de resistência, sob pena de definhar no isolamento de suas próprias reservas, é impensável entender as estruturas do poder, a divisão de competências e o sistema normativo tal como moldados até os anos 1980. É inegável que o sagrado princípio da legalidade e o ato administrativo não podem mais ser cultuados como sempre foram.

A sua concepção inicial, de tutela de liberdades do indivíduo contra o Estado, restringia-se à obtenção de total submissão da Administração à lei. Essa concepção só se mostrava eficaz se a hierarquia entre lei e regulamento fosse objetivamente garantida. Sacrificava-se a eficiência do ato em prol da segurança jurídica. A solução ideal parecia estar na forçada submissão da Administração aos princípios que conformam o Estado de Direito, vinculando a sua atividade à soma dos valores que compõem o ordenamento como um todo. A excessiva abstração dos princípios e a conseqüente ausência de parâmetros

55 FARIA, José Eduardo. Declaração Universal dos Direitos Humanos: um cinqüentenário à luz da globalização econômica. 
objetivos, no entanto, impediram a plena realização da vinculação do Estado aos belos enunciados constitucionais. Exemplo dessa dificuldade é a exigência de violação direta a normas infraconstitucionais concretizadoras de determinados princípios. A ofensa ao devido processo legal, por exemplo, só pode ser objeto de apreciação judicial se um dispositivo legal de ordem processual for negligenciado. Dessa forma, as ofensas diretas aos princípios são raras, excepcionais e não-representativas.

Não se pense, com isso, que o princípio da legalidade tenha perdido parte de sua preponderância no sistema, ao contrário, sob um novo enfoque ficou ainda mais fortalecido. A discussão sobre o seu limite apenas indica que ele deve ser encarado de outra maneira, muito mais ampla, mas nem por isso menos relevante. Se sistemas e microssistemas em rede disputam com o Direito positivado pelo Estado a extrema volatilidade dos fatos que determinam a vida socioeconômica de seu povo, é totalmente absurdo regular atos relacionados com o Direito Econômico e controlar seus efeitos políticos e sociais com o mesmo ordenamento jurídico restrito e imutável de antes, supostamente isento de lacunas e de exceções não previstas em lei. Precisamente por isso, José Eduardo Faria ressalta a "flagrante provisoriedade e mutabilidade de suas engrenagens normativas".

A relatividade das normas que compõem o sistema normativo deve-se à liquidez da modernidade em seu atual estágio. Participamos de um tempo que Galbraith chamou de era da incerteza, e Bauman, de modernidade líquida. Tudo o que é sólido se desfaz para se transformar em alguma outra coisa, qual uma fênix de vida breve, capaz de constantemente renascer e assumir novas formas de vida. O extremo dessa volatilidade certamente faz desses conturbados tempos de crise global algo impensável até mesmo para a visão crítica dos dois autores que acabamos de lembrar.

Sucede que toda essa transformação ocorre à margem das categorias jurídicas e dos mecanismos de controle tradicionalmente utilizados. Às normas editadas pelo Executivo nacional ajuntam-se a profusão de normas baixadas pelas autoridades dos países mais ricos, a Lex mercatoria e as normas impostas por organismos multilaterais e setores privados nacionais. O resultado, como é intuitivo, torna virtualmente impossível a pretensão de manter a idoneidade lógica de sistemas e subsistemas de Direito positivado, já que o Estado não tem qualquer controle sobre a revolução econômica que acontece fora de nossas divisas, mas, mesmo assim, precisa administrar as convulsões internacionais com medidas internas que variam ao sabor de fatos e prognoses feitas pelos outros Estados e, especialmente, da ambição dos investidores. 
Essas medidas, todavia, extremamente técnicas, guardam um forte conteúdo político, tendo em vista que a união que a crise produz é apenas aparente. Todos colaboram para a redenção econômica oferecendo seu quinhão de sacrifícios, mas ninguém abandona o interesse primário de lucrar o máximo possível com a crise. A solidariedade é real na medida em que preserva o egoísmo, porquanto a competição continua a ser o estímulo daqueles que participam do jogo. Assim, a normatividade dos Estados encontra um estímulo de impulsão que ignora conceitos e princípios que se julgava indispensáveis na produção e interpretação do Direito. Legalidade, isonomia, direitos subjetivos, razoabilidade, proporcionalidade, equilíbrio econômico dos contratos, segurança jurídica e tantas outras categorias jurídicas ainda teriam espaço assegurado na concepção da norma jurídica editada para acompanhar o vendaval que assola o planeta?

Diante disso, assegurar a racionalidade lógico-formal do sistema normativo parece ser uma atitude absolutamente inconseqüente. Quais, enfim, são as medidas necessárias para pensar o Direito condizente com as estruturas de poder que assomam nesse início de século? Se há muito se admite a inoperância da fórmula que pretendia constitucionalizar em breve intervalo de tempo as relações sociais, que dizer do modelo jurídico que está prestes a perder a sua referência normativa? Segundo Tercio Sampaio Ferraz, ${ }^{56}$ a positivação é a institucionalização da mutabilidade do Direito e por isso pressupõe a dinâmica do sistema, mas as extremas heterogeneidade e provisoriedade de parte de suas normas, inseridas em uma estrutura artificialmente prolongada de poder, conspiram contra a unidade sistêmica da ordem normativa. Para preservar a sua autoridade, é preciso ousar sem abandonar a segurança jurídica indispensável para a eficácia do ordenamento.

Não se está a propor, no entanto, a solução simplista da substituição de um Código por outro, como se pretendeu com a Constituição em relação ao Código Civil, antigo centro do sistema, mas fazer com que o modelo de ordenamento existente passe a funcionar mediante uma nova visão política do pacto federativo e do poder. O mundo que queremos ver funcionando e o respeito devido aos direitos e garantias fundamentais dependem de nós, não são atribuição do legislador. Definir o Direito pelo seu potencial coercitivo e pelo único foco do instrumento elaborado para criá-lo significa pensar que a dignidade da vida depende da autoridade do emissor da declaração legislativa. Essa sobrevida concedida ao Iluminismo faz com que o Direito seja pensado como ciência, já

56 FERRAZ JR., Tercio Sampaio. Introdução ao estudo do direito. 4. ed. São Paulo: Atlas, 2003, p. 180. 
que ele deve surgir diretamente de regras e dos princípios expressos, e ser definido por sua conseqüência: a sanção.

A intersecção entre Direito e economia sempre exigiu complexos conhecimentos desses dois ramos do conhecimento e demanda o cuidado de conciliar seus princípios estruturantes de uma maneira ainda mais complexa, ou seja, sem desvirtuar princípios econômicos e regras de Direito. Sucede que essa equação, em si tão complicada, tornou-se ainda mais incerta, posto que dependente de variáveis imprevisíveis surgidas na realidade da vida compartilhada globalmente. No momento em que essas variáveis passaram a determinar a impossibilidade de o Estado-nação assegurar o mínimo existencial a seus nacionais, a realidade cambiante adquiriu um peso consideravelmente maior na equação. Se assim é, o Direito não pode restar imutável, uma vez que os fatos são irresistíveis.

O primeiro passo a ser dado para reorganizar a equação e fazer prevalecer a dignidade da vida consiste em reconhecer o óbvio, que é a crise político-social e econômica por que passamos. O segundo é admitir que a crise é duradoura o bastante para ser considerada permanente. O vocábulo "permanente" é utilizado pela doutrina não para caracterizar o que é perpétuo, mas como modo de qualificar aquilo que é duradouro, persistente. Essa persistência permite que o estado de exceção não continue a ser tratado como mera quaestio facti e mereça assumir o status de uma legítima questão de Direito. A dificuldade de sua aceitação tem a ver com a indefinição de seu conceito e a vaga constatação de que resulta do desequilíbrio entre fato político, econômico e social e o Direito Público. O filósofo italiano Giorgio Agamben, ${ }^{57}$ um dos poucos jusfilósofos que se debruçaram sobre o tema do estado de exceção, merece ser transcrito para melhor compreensão dos argumentos a seguir expostos:

Segundo opinião generalizada, realmente o estado de exceção constitui um
"ponto de desequilíbrio entre direito público e fato político" (Saint-Bonnet,
2001, p. 28) que - como a guerra civil, a insurreição e a resistência - situa-se
numa "franja ambígua e incerta, na intersecção entre o jurídico e o político"
(Fontana, 1999, p. 16). A questão dos limites torna-se ainda mais urgente: se são
fruto dos períodos de crise política e, como tais, devem ser compreendidas no
terreno político e não no jurídico-constitucional (De Martino, 1973, p. 320), as
medidas excepcionais encontram-se na situação paradoxal de medidas jurídicas
que não podem ser compreendidas no plano do direito e o estado de exceção
apresenta-se como a forma legal daquilo que não pode ter forma legal. Por outro
lado, se a exceção é o dispositivo original graças a que o direito se refere à vida e
a inclui em si através de sua própria suspensão, uma teoria do estado de exceção
é, então, condição preliminar para se definir a relação que liga e, ao mesmo
tempo, abandona o vivente ao direito.

57 AGAMBEN, Giorgio. Estado de exceção. 2. ed. São Paulo: Boitempo, 2007, p. 11-12. 
De fato, o Direito Público consegue abranger as exceções razoáveis que desbordam da normalidade das coisas, porém há uma zona de intersecção que não pode ser tratada exclusivamente como fato político nem como ato jurídico. Os fatos que habitam essa zona de incerteza refogem dos limites que usualmente conferem aos fatos a regulação prevista no ordenamento. Há um ponto além do qual o fato político precisa ser disciplinado pelo Direito, já que possui densidade suficiente para interferir no reconhecimento de direitos fundamentais. Ignorá-lo parece ser um sebastianismo verdadeiramente suicida: a fé irracional na solução dos desajustes que minam a economia desafia as evidências dos graves danos que se acumulam diante de todos.

Entre o Direito Público e o fato econômico há um hiato que não pode ser desconsiderado, em razão de sua prolongada permanência. Como a exceção não é passageira nem se consumou em um determinado fato histórico, só suscetível de produzir efeitos indiretos - como aconteceu na punição de Eichmann, mesmo sem norma anterior que considerasse crime o genocídio -, torna-se absolutamente indispensável reconhecer o problema e aplicar medidas corretivas e preventivas de longo prazo para reverter a situação. Seria, então, impróprio suscitar a momentânea suspensão do Direito, porquanto só uma regulação específica voltada para minimizar os efeitos dos fatos que compõem o estado excepcional seria de alguma utilidade.

Note-se que o estado de exceção permanente não é um descontrole pontual que se esvai, retornando a normalidade com as medidas tomadas após a suspensão de uma parcela da ordem jurídica. Se a exceção decorrer de uma crise econômica, por exemplo, ela pode ser permanente ou passageira. Se passageira, suspende-se, pelo tempo necessário, a eficácia do ordenamento para se combater diretamente os fatos que dão origem à crise. A ação governamental, nesse caso, tem a finalidade específica de eliminar a própria crise. Com a exceção permanente, a situação é inversa, atacam-se os efeitos da crise, já que os atos editados pelo governo não podem ir além da minimização dos danos que ela permanentemente provoca. A superação da própria crise, se permanente, é tarefa muito mais complexa, que depende de muitas outras variáveis, como a economia global. A crise não é o estado de exceção, é o fato histórico que conduz, talvez de maneira preponderante, ao reconhecimento de que norma e realidade não mais se relacionam. Teríamos, então, normas vigentes sem aplicação, e normas sem vigência efetivamente aplicadas.

É importante reconhecer o estado de exceção permanente porque essa patologia altera parâmetros até então tidos como indiscutíveis: normas incompatíveis com valores historicamente admitidos e em contraste com a realidade fática deixam de ser, como até 
aqui acontecia, ilegítimas e ineficazes para se tornarem somente inadequadas e inoperantes. A norma que pune o jogo do bicho, por exemplo, não é aceita pela quase totalidade da população, mas continua vigente, apesar de sua ilegitimidade e ineficácia. Com a exceção permanente acontece o contrário, pois os valores e a realidade fática não são conhecidos senão por poucos especialistas. A grande diferença reside no seguinte argumento: a ilegitimidade e a ineficácia das normas devem provocar uma normatização de fatos e valores que ainda não possuem densidade suficiente para provocar a reação do Poder Legislativo. Apesar disso, ao Executivo e ao Judiciário não é lícito aguardar a consolidação de fatos e valores, já que devem regulamentar situações que apenas potencialmente continuarão a produzir danos. Muitas vezes, em razão de simples prognósticos de prejuízos anunciados pela conjuntura econômica mundial, as autoridades econômicas devem se antecipar aos fatos e editar medidas que alteram o programa governamental como um todo.

Qual a medida que não se apresentará como demasiada, ou muito pouca? Que parâmetros objetivos podem ser aplicados para justificar a normatização de valores e fatos assentados sobre meros prognósticos técnicos?

Para se chegar à conclusão de que apenas um macrocontrole social pode garantir um equilíbrio razoável entre segurança e efetividade, é preciso, além de reconhecer a relevância do momento histórico atual e do perfeito entendimento do conceito de estado de exceção permanente, uma prévia consideração da tridimensionalidade do direito e do razoável equilíbrio entre fato, valor e norma. Essa visão de correlação dos elementos componentes da tridimensionalidade nos foi dada por José Renato Nalini, culto desembargador do Tribunal de Justiça do Estado de São Paulo, em sua obra "Filosofia e Ética Jurídica”, Capítulo III, "A teoria tridimensional do Direito". A partir de seus ensinamentos, pode-se entender por que estado de exceção permanente é fato que possui peso infinitamente maior que norma e valor aparentemente legítimos e eficazes:

\footnotetext{
Avizinham-se questões que permitirão constatação escancarada de que a tridimensionalidade específica não é formulação meramente retórica, mas estratégia hábil para a mais adequada apreensão do fenômeno jurídico. (...)

Tudo isso deve ser observável à luz da tridimensionalidade. Fatos novos, sob enfoque de determinado valor, sugerem elaboração normativa nova. Mesmo fatos, sob incidência de valores novos, gerarão normas novas. Fatos que vierem a perder frequiência acarretarão leniência à força cogente da lei. A figura do tripé ainda serve a tornar claro o modelo de tridimensionalidade: fato, valor e norma precisam estar no mesmo estágio de equilíbrio. ${ }^{58}$
}

58 NALINI, José Renato. Filosofia e ética jurídica. São Paulo: RT, 2008, p. 423-432. 
A norma de Direito Positivo editada para reequilibrar a equação que perdeu sua legitimidade faz ver que normas constitucionais definidoras de competências também apresentam a característica da relatividade. Com a preponderância do elemento fato e em face de um dano que se mostra apenas provável, não somente é suspensa a norma vigente como justifica-se a edição de outras normas aparentemente ilegais. Não foi por outra razão que o Supremo Tribunal Federal não considerou inconstitucional o plano econômico que congelou os depósitos bancários de toda a população no Governo Collor. Por evidente, a Justiça não ousou interceptar uma política que se mostrava claramente inconstitucional, uma vez que apresentava fundamento não-científico, que somente poderia ser comprovado depois da ocorrência de fatos danosos ou benéficos.

Exatamente em razão da enormidade dos danos prováveis é que o estado de exceção permanente não pode dispensar a participação de todos os atores envolvidos nas medidas que precisam ser tomadas. A participação do ator social, no entanto, mesmo sendo efetivo somente a partir de um determinado grau de envolvimento do cidadão na cogestão do interesse público, justifica-se durante toda a longa fase em que sua cidadania é forjada. Mesmo nos casos em que se torna impossível e desaconselhável a prévia publicidade das opções político-econômicas do governo, como acontece com as medidas relativas à flutuação da taxa de juros, ao câmbio e ao comércio exterior, a participação popular no julgamento das medidas excepcionais deve acontecer na flagrância dos fatos, tal como tem acontecido nos países desenvolvidos afetados pela crise econômica. As reivindicações da indústria automobilística americana e as pressões populares exercidas sobre o Congresso são um significativo exemplo de controle social sobre questões técnicas de políticas econômicas. Ainda que a decisão final não possa ser impugnada formalmente pelo povo, a reação manifestada contra medidas consideradas inadequadas é capaz de influir decisivamente na solução encontrada nos acordos firmados entre o Legislativo e o Executivo. Pode-se afirmar, guardadas as proporções dos significados técnicos específicos, que busca-se uma espécie de contencioso legitimador das opções que são, a um só tempo, técnicas e políticas.

Convém relevar, prosseguindo na demarcação dos limites de fato, valor e norma, que a crise econômica apenas se ajunta a uma situação deteriorada consolidada ao longo dos anos. A sua violência deve-se ao lento desmoronamento da economia e apresenta-se como produto de inúmeras causas, como políticas públicas equivocadas, corrupção e valores éticos sistematicamente desconsiderados. A quebra da Bolsa de Nova York em 
1929, por exemplo, não representava mais do que um sintoma de uma crise muito mais profunda, que literalmente devastava a economia norte-americana. As medidas tomadas por Roosevelt a partir de 1933 tinham a específica finalidade de reerguer a economia dos Estados Unidos como um todo. A revitalização do mercado acionário apenas refletiu o saneamento da economia e a possibilidade reconquistada de o Direito tornar a controlar os fatos políticos e econômicos.

É intuitivo que a expressão "estado de exceção" possua conceito ambíguo e possa ser utilizada para qualificar "estado de necessidade", "estado de sítio", "de guerra", "decretos de urgência", "martial law" e "emergency powers", mas, em um sentido estrito, refere-se à suspensão do ordenamento, já que a exceção, exatamente por ser imprevisível, não pode ser previamente regulada. Ela pressupõe ausência de Direito, anomia, não Direito especial, como Direito de Guerra, ou eventual lacuna que o intérprete é obrigado a preencher com elementos do sistema. Os próprios fatos excepcionais é que determinam os limites razoáveis da suspensão da ordem jurídica e a forma como o vazio deve ser preenchido.

No estado de exceção, verifica-se um retorno a um estado quase-natural, no qual ainda não se teria definido uma perfeita distribuição de competências entre os Poderes de Estado. A eventual concentração de atribuições em um único Poder parece fazer ressurgir uma época em que algumas das características do Estado de Direito moderno ainda não se mostravam plenamente demarcadas. $\mathrm{O}$ vazio de direito permite que a autoridade assuma, temporariamente, poderes soberanos para o desate da questão que lhe é submetida.

Até aqui, tudo bem, mas o que acontece se a situação excepcional perdurar até se tornar, ela própria, regra ordinária? No Capítulo 1 sustentou-se que a regra de calibração de efeitos permanentes, exatamente por suspender o padrão de legalidade, acaba por perder a legitimidade inicial. As sucessivas crises econômicas e políticas; a crônica insuficiência de recursos públicos; a doença e a morte desassistidas são males permanentes. Essas hipóteses não caracterizam, elas próprias, a exceção reclamada para a suspensão da ordem jurídica, posto que configuram apenas os dramáticos efeitos do desajuste maior da própria economia. A crise internacional que afeta todos os Estados, ricos, emergentes e pobres, evidentemente configura um estado de emergência real, não fictício. É compreensível, diante dela, que o Executivo acumule poderes que normalmente não lhe pertenceriam, já que o moroso tráfego de providências no Legislativo não permite a imediata resposta que a exceção reclama. 
Torna-se difícil, portanto, admitir que o chamado "estado de exceção permanente" possa ser resolvido por uma norma de calibração, ou justificar a suspensão permanente de normas de Direito Positivo. A questão assume relevância em face das dificuldades econômicas atuais, visto que, se as previsões pessimistas dos experts estiverem corretas, a exceção terá de conviver, por um longo tempo, com a normalidade. Não se pode, nessa hipótese, fazer uma opção tão simples quanto suspender a ordem jurídica indeterminadamente, ou tão irresponsável como vivermos na pura abstração do desastre, como se nada estivesse ocorrendo à nossa volta.

O que fazer? Regular ou não regular o estado de exceção, e em que proporção? Milton Friedman, Prêmio Nobel de Economia, referiu-se certa vez a três demônios: "Não existe, infelizmente, uma boa solução para o monopólio técnico. Existe apenas a escolha entre três demônios: o monopólio privado desregulamentado; o monopólio privado regulamentado pelo Estado e a produção estatal" ${ }^{\text {59 }}$. A lição prende-se ao tema da regulamentação ou desregulamentação do mercado, mas se aplica com perfeição à positivação da exceção. Esta seria uma forma de admitir o que não pode ser negado: os poderes excepcionais do Estado constituem opção irrenunciável como última forma de preservá-lo na ocorrência de um estado de necessidade incontrolável, já que os rígidos esquemas implantados para proteção dos particulares são úteis somente em tempos de normalidade. Se a exceção não for tratada excepcionalmente, as mesmas defesas que garantem o cidadão contra o arbítrio do Estado serão a causa de seu aniquilamento.

As opções oferecidas, também aqui, levam diretamente a três demônios, tal como no monopólio técnico: a positivação de critérios objetivos para lidar com exceções; a constatação da impossibilidade de regular o que não pode ter forma jurídica predeterminada; e a tolerância com ordens normativas paralelas, que se infiltram de tal maneira no Direito positivado que acabam por torná-las indistinguíveis, obrigando-nos a conviver com um sistema permanentemente híbrido. Essa simbiose, mutuamente proveitosa a princípio, agrega normas excepcionais ao ordenamento jurídico com o único intento de suplantar uma determinada dificuldade, mas acaba por tornar impossível a volta à normalidade, já que é extremamente fácil e convidativo utilizar a violência institucionalizada. Com elas, suspendem-se direitos e garantias fundamentais sem nenhum pudor.

59 FERRAZ JUNIOR, Tercio. Prefácio da obra "Competitividade: mercado, estado e organização", de Elizabeth M. M. Querido Farina. Matéria extraída da internet. Disponível em: <http://www.terciosampaioferrazjr.com.br/?q=/publicacoes-cientificas/115>. Acesso em: 26 dez. 2008. 
No exato instante em que a norma de exceção ingressa no Direito Positivo, desaparece a essência do que lhe dá validade, a vontade de restaurar a ordem anterior suspensa, e faz surgir uma nova ordem, duradoura e imperfeita. Na verdade, a regra vive da exceção, pois é ela que delineia os contornos das regras da normalidade. Quando se mostram indiscerníveis, o paradigma de governo transforma-se para tornar indefinidos e borrados os limites entre democracia e absolutismo.

O exemplo mais evidente dessa confusão, para não retrocedermos ao período da Alemanha nazista, aconteceu nos Estados Unidos depois do atentado que destruiu as torres gêmeas e espalhou o pânico entre os países ocidentais. Assim como a guerrilha revolucionou o conceito de guerra, como se pôde ver na resistência que impediu a dominação dos Estados Unidos desde o Vietnã até o Iraque e Afeganistão, apesar de seu poderio militar, os atentados terroristas são uma forma de conflito eficaz e anônimo. Não há um Estado ou um grupo ligado a um determinado país que possa ser formalmente responsabilizado, nem ato declaratório de guerra, já que os responsáveis são desconhecidos. As medidas preventivas tomadas nessa guerra informal dirigem-se, perigosamente, contra uma raça, uma determinada religião, ou outra característica tão abstrata como essas.

Sucede que os Estados Unidos estão tão empenhados em sua guerra contra o terrorismo internacional e não usam, na prática, o vocábulo guerra como metáfora, ao contrário, afastam-se do Direito Internacional e dos direitos humanos que ajudaram a consolidar o seu prestígio, repetindo a mesma retórica dos seus oponentes anônimos, de reduzidíssimo número.

Giorgio Agamben presta as seguintes informações a respeito da consolidação do estado de exceção como paradigma de governo nos Estados Unidos:

\footnotetext{
O significado imediatamente biopolítico do estado de exceção como estrutura original em que o direito inclui em si o vivente através de sua própria suspensão aparece claramente na "military order", promulgada pelo presidente dos Estados Unidos no dia 13 de novembro de 2001 e que autoriza a "indefinite detention" e o processo perante as "military commissions" (não confundir com os tribunais militares previstos pelo direito da guerra) dos não cidadãos suspeitos de envolvimento em atividades terroristas. Já o "USA Patriot Act", promulgado pelo Senado no dia 26 de outubro de 2001, permite ao attorney general "manter preso" o estrangeiro ("alien") suspeito de atividades que ponham em perigo "a segurança nacional dos Estados Unidos"; mas, no prazo de sete dias, o estrangeiro deve ser expulso ou acusado de violação da lei sobre a imigração ou de algum outro delito. A novidade da “ordem" do presidente Bush está em anular radicalmente todo estatuto jurídico do indivíduo, produzindo, dessa forma, um ser juridicamente inominável e inclassificável. Os talibãs capturados no Afeganistão, além de não gozarem do estatuto de POW (prisioneiro de guerra), segundo a Convenção de Genebra,
} 
tampouco gozam daquele de acusado segundo as leis norte-americanas. Nem prisioneiros nem acusados, mas apenas "detainees", são objeto de uma pura dominação de fato, de uma detenção indeterminada não só no sentido temporal, mas também quanto à sua própria natureza, porque totalmente fora da lei e do controle judiciário. A única comparação possível é com a situação jurídica dos judeus nos "Lager" nazistas: juntamente com a cidadania, haviam perdido toda identidade jurídica, mas conservavam pelo menos a identidade de judeus. Como Judith Butler mostrou claramente, no "detainee" de Guantánamo a vida nua atinge sua máxima indeterminação. ${ }^{60}$

Na base militar de Guantánamo, em uma inequívoca demonstração de que o regime excepcional de suspensão de direitos e garantias fundamentais convive com o governo democrático norte-americano, quase 400 detentos são mantidos presos há sete anos sem acusação formal e sem direito de requerer habeas corpus ao Tribunal Federal em Washington. O jornal $O$ Globo, edição de 12 de junho de 2008, relata que o centro de detenção de Guantánamo tem pelo menos 385 presos: de 60 a 80 serão processados por um tribunal militar, 85 serão devolvidos a seus países de origem e 200 encontram-se em uma espécie de limbo legal.

Somente em junho de 2008 a Suprema Corte decidiu que os suspeitos de terrorismo presos nessa base têm o direito de recorrer a juízes federais para serem libertados e que uma lei editada em 2006 para lhes tirar o direito de pleitear habeas corpus teria seus efeitos suspensos. O juiz Anthony Kennedy confirmou que os prisioneiros possuem direito a habeas corpus e que "As leis e a Constituição são pensadas para sobreviver, e continuar em vigor, mesmo durante circunstâncias extraordinárias”.

A decisão é extremamente importante porque, pelo menos em tese, reconhece que presos considerados prisioneiros de guerra pela administração Bush têm direitos protegidos pela Constituição norte-americana e que os tribunais militares não possuem autoridade para mantê-los presos sem culpa formada.

O estado de exceção norte-americano, formalmente positivado em seu ordenamento depois de 2001, torna a questão ainda mais dramática, já que por sete longos anos o governo e toda a sociedade dos Estados Unidos continuaram a louvar a sua postura de respeito aos direitos humanos ao mesmo tempo em que ignoravam a vergonha conscientemente tolerada em sua base militar. O próprio presidente Bush mostrou-se publicamente revoltado com a ameaça parlamentar de colocar um ponto final nos ilegítimos meios de tortura empregados no combate ao terrorismo:

60 AGAMBEN, Giorgio. Estado de exceção, p. 14-15. 
O presidente George W. Bush disse neste sábado, 8, que vetou uma legislação em tramitação no Congresso dos Estados Unidos que baniria a CIA (Agência Central de Inteligência, em inglês) de usar métodos de interrogatório como o "waterboarding" (que simula um afogamento) em suspeitos de terrorismo. A razão principal dada por Bush é que a lei iria impossibilitar práticas que têm prevenido ataques terroristas.

"O projeto de lei que o Congresso me enviou iria acabar com uma das ferramentas mais valiosas da guerra contra o terror", disse o presidente no seu programa semanal de rádio transmitido neste sábado. "Por isso vetei." O projeto de lei incluía regras gerais para serviços de inteligência, e foi aprovado pelo equivalente à Câmara dos Deputados dos EUA em dezembro de 2007 e pelo Senado no último mês. "Essa não é a hora para o Congresso abandonar práticas que se provaram eficientes na tarefa de manter a América segura", disse Bush.

A lei iria limitar os interrogadores da CIA a 19 técnicas que são permitidas no manual de campo do exército. Esse manual baniu, em 2006, o uso de técnicas como o "waterboarding" ou outras de depravação sensorial em prisioneiros que não cooperassem. Bush disse que a CIA deve manter o uso de "procedimentos especializados de interrogatório" que o serviço militar não precisa usar. Para o presidente, "enquanto os militares interrogam combatentes capturados em áreas de conflito, os profissionais das áreas de inteligência lidam com terroristas perigosos que foram treinados para resistir a técnicas como as do manual do Exército".

"Nós criamos procedimentos alternativos para questionar os operantes mais perigosos da al-Qaeda, particularmente aqueles que podem ter conhecimento de ataques planejados para nosso território", disse Bush. "Se nós acabarmos com esse programa e restringirmos os métodos usados pela CIA àqueles descritos no manual militar, poderemos perder informações vitais de terroristas de alto escalão da al-Qaeda, e isso poderá custar vidas americanas."

A prática do waterboarding consiste em amarrar a pessoa, colocar um capuz em sua cabeça e jogar água, para causar uma sensação de afogamento. $O$ waterboarding já foi condenado por nações e organizações de direitos humanos de todo o mundo. ${ }^{61}$

Não é só no berço da democracia moderna, no entanto, que o estado de exceção fincou raízes. No Brasil, convivemos com exceções permanentemente integradas ao Direito. Dispositivos destinados a privilegiar a Fazenda Pública nos pagamentos de precatórios decorrentes de sentença judiciária e, em especial, o sistema de parcelamento instituído pela Emenda Constitucional n. 30 nada mais são que medidas excepcionais positivadas em nossa Lei Maior. Mais significativos ainda são os dispositivos legais editados para impedir a concessão de liminares e antecipações de tutela em desfavor da Fazenda Pública, como a Lei n. 9.494/97. Se a norma impede, objetivamente, a concessão de liminares, é indiscutível estar havendo uma substituição indevida do juiz pelo legislador na tarefa de avaliar a oportunidade da medida. Ele está, no caso, valorando aquilo que deveria ser objeto da cognição do magistrado. Por que, então, essas leis não foram declaradas inconstitucionais? Porque são medidas consideradas necessárias, pelo

61 O Estado de S. Paulo. "Bush veta lei que limitaria tortura em interrogatórios - Técnica de afogamento é mantida pelo presidente dos EUA para 'manter a América segura'”, Caderno Internacional, edição de 8 mar. 2008. 
legislador, para garantir a preservação do Tesouro, a qualquer custo, até o trânsito em julgado da sentença condenatória.

A suspensão de segurança, liminar ou sentença também é medida de suspensão do Direito, especialmente do princípio da confiança legítima, já que depois de anos de batalha judicial, justamente quando o credor do Estado poderia, finalmente, executar o seu crédito, uma medida completamente independente da matéria de direito debatida na ação empurra a execução da condenação para um longínquo e incerto futuro. $\mathrm{O}$ fundamento, bem o sabemos, depende exclusivamente da má condição econômica do Poder Público. Por não ser exigida a comprovação da excelência dos meios empregados para aplicar o dinheiro público, basta a exposição dos efeitos que a má gestão produziu para frustar qualquer esperança daquele que teve seu direito reconhecido pela Justiça.

Outro exemplo da banalidade dos males processuais é a ordinária invocação da cláusula do financeiramente possível. Essa figura jurídica de extrema valia, que deveria ser utilizada também com extrema excepcionalidade, premia a má gestão e estimula os gastos perdulários dos governantes. Pode-se lembrar, a propósito, a terrível advertência de São Tomás de Aquino, no seguinte sentido: há uma caridade que castiga, assim como uma maldade que perdoa.

Essas e outras medidas excepcionais, utilizadas ordinariamente, caracterizam o estado de exceção permanente e levam as instituições ao descrédito, ainda que solucionem a questão imediatamente colocada à consideração dos Tribunais Superiores. A lição de Konrad Hesse detalha com perfeição a ilusória vantagem de tentar resolver uma questão prática com a suspensão da normatividade da Constituição:

Todos os interesses momentâneos - ainda quando realizados - não logram
compensar o incalculável ganho resultante do comprovado respeito à
Constituição, sobretudo naquelas situações em que a sua observância revela-se
incômoda. Como anotado por Walter Burckhardt, aquilo que é identificado como
vontade da Constituição "deve ser honestamente preservado, mesmo que, para
isso, tenhamos de renunciar a alguns benefícios, ou até a algumas vantagens
justas. Quem se mostra disposto a sacrificar um interesse em favor da
preservação de um princípio constitucional, fortalece o respeito à Constituição e
garante um bem da vida indispensável à essência do Estado, mormente ao Estado
democrático". Aquele que, ao contrário, não se dispõe a esse sacrifício,
"malbarata, pouco a pouco, um capital que significa muito mais do que as
vantagens angariadas, e que, desperdiçado, não mais será recuperado". ${ }^{2}$.

Para corroborar a afirmação de que convivemos com um estado de exceção permanente, enfatizamos que a inegável existência de sistemas paralelos, à margem das

62 HESSE, Konrad. A força normativa da constituição. Tradução de Gilmar Ferreira Mendes. Porto Alegre: Fabris, 1991, p. 21-22. 
normas positivadas, nada mais representa que a explícita comprovação de existência desse estado. Como a relação entre o ordenamento legítimo e o paralelo persiste indefinidamente, uma vez que o Estado não consegue suplantar as dificuldades que determinaram a edição das normas excepcionais, a volta à normalidade torna-se impossível, já que essas normas passaram a integrar o ordenamento. A simbiose inicial, a partir de então, desaparece. Confundindo-se com o resto do ordenamento, essas normas passam a viger despidas da inicial condição de instrumentalidade. Gordillo, a propósito, afirma o seguinte:

\begin{abstract}
El parasistema no está entonces en guerra declarada contra el sistema, sino que es parasitario de él, lo usa y lo debilita. El uso que el parasistema hace del sistema reside, entre otras cosas, en que el aparato formal del Estado concurre con su mecanismo de sanciones para castigar no al que meramente viola el sistema, que casi todo el mundo lo hace, sino en verdad al que transgrede el parasistema.

Dado que este sistema escrito, por ejemplo visiblemente muchos extensos reglamentos administrativos, se formula no para ser cumplido y aplicado fielmente, sino sólo para establecer un punto de referencia ideal y teórico, alejado de la realidad del cumplimiento diario por la sociedad, se pueden incorporar a él pautas todavía más exigentes que aquellas que se introducirán si fueran a ser cumplidas. En el sistema se pueden entonces plasmar las aspiraciones idealistas, ya que no las proposiciones realistas. En lugar de concebirlo como un instrumento que puede intentar moldear la realidad dentro de la medida de lo posible y razonable, se lo percibe como el lugar donde plasmar tantos ideales como sea posible imaginar. En lugar de instrumento social se transforma en instrumento literario. Pero entonces ese sistema nace sin autoridad, pues al reconocerse que no se aplica ni es para ser aplicado en lo que tiene de irreal y exagerado, entonces se debilita su fuerza como norma aplicable en el resto. Y con él trastabilla y renguea todo el orden jurídico y social. ${ }^{63}$
\end{abstract}

A corroborar esse ensinamento, sem adentrar no extenso campo da possibilidade de positivação de normas excepcionais, apenas se enfatiza que essa prática é absolutamente indesejável, exatamente por não se poder prever, ex ante, todas as hipóteses possíveis. Alfonso García Figueroa, ${ }^{64}$ professor titular da Universidade de Castilla-La Mancha, ao expor o seu pensamento sobre a questão de enumerar exaustivamente as exceções que poderão ocorrer no futuro, traz o apropriado e didático ensinamento de Karl Popper:

En cierta ocasión, en La Edad de Piedra, usted y yo estamos discutiendo sobre el futuro y yo predigo que dentro de los próximos diez años alguien inventará la rueda. “¿Rueda?”, pregunta usted. “¿Qué es eso?” Entonces yo le describo la rueda, encontrando palabras, sin duda con dificultad, puesto que es la primeríssima vez que se dice lo que serán un aro, los radios, un cubo y quizá un eje. Entonces hago una pausa, pasmado: "Nadie inventará la rueda, porque acabo de inventarla yo". En otras palabras, la invención de la rueda no puede ser

63 GORDILLO, Agustín. Disponível em: 〈http://www.gordillo.com/Pdf/AdmP/ap2.pdf>. Acesso em: 26 nov. 2008.

64 FIGUEROA, Alfonso García. Réplica al profesor Thomas da Rosa Bustamante. Revista de Direito do Estado, Rio de Janeiro, Renovar, n. 8, p. 147, out./dez. 2007. 
predicha. Una parte necesaria para predicir esa invención es decir lo que es una rueda.

Da mesma forma, a condição necessária para predizer todas as exceções que uma regra pode apresentar no futuro seria conhecê-las no passado. É dizer, se o legislador não desejar fixar uma enumeração taxativa, relacionada em numerus clausus, apenas poderá estabelecer, ex ante, uma enumeração exemplificativa.

Diante do exposto, somos forçados a reconhecer que não há como ignorar os estados de exceção que assombram tanto economias diligentes quanto Estados irresponsáveis. Eles surgem inesperadamente, tal como os sacis vermelhos dos erros tipográficos referidos por Monteiro Lobato, desafiando qualquer previsão e toda cautela tomada para equilibrar segurança e efetividade. A excepcionalidade não se ignora, exige ações positivas por parte do Estado, que só se legitimam mediante um controle social atuante e eficaz. Não há, porém, gestão ideal nem técnica avançada capazes de preservar o equilíbrio daqueles dois valores. A solução, como vem sendo dito, depende da adoção de complexas fórmulas de controle de gastos públicos e necessidades mínimas do ser humano, obtidas em um fórum de vastíssimas proporções de influência política. Se questões éticas moldaram a crise americana, que foi sentida com intensidades variáveis nos Estados em rede, por razões locais igualmente éticas, parece claro que os futuros paradigmas só podem ser eficientemente implantados se uma nova moral, desta vez consolidada em conjunto com as sociedades locais, conduzir a um equilíbrio ético entre o relativo e o permanente, ou seja, entre o subjetivismo e a objetividade da nova escala hierárquica de valores.

No Brasil, não estamos vivendo somente mais uma crise mas o fim de uma época em que aproveitamos os efeitos benéficos das "bolhas" artificialmente criadas no exterior por mercados desregulamentados muito pouco éticos. O liberalismo extremo, segundo Alain Touraine ${ }^{65}$, acabou por determinar uma volta a Keynes e o conseqüente abandono da cega confiança no valor dos mercados. Uma nova regulação virá, diferente da anterior, posto que inspirada em uma simbiose ética entre Estado e sociedade, entre o público e o privado. Não se trata mais de reconhecer a perda de seus contornos, mas de um novo modelo de gestão participativa, já que trilhões de dólares foram investidos pelos Estados na economia privada. O sistema de seguros nos Estados Unidos, por exemplo, foi praticamente nacionalizado. Os valores colocados à disposição dos Bancos também não

65 Jornal O Estado de S. Paulo. Entrevista com Alain Touraine: "Está havendo uma limpeza das elites: para sociólogo, a crise acelera uma troca de gerações na elite, com a saída de 'aproveitadores do sistema e mesmo ladrões"”, caderno Economia, p. B11, edição de 21 de dezembro de 2008. 
afastam uma participação nos resultados. É impossível dizer que um novo paradigma não surgiu.

Esse novo modelo, que naturalmente não pode ser um mero retorno à estatização, nem qualquer tipo de neoliberalismo conhecido, só pode fundar-se em um choque ético verdadeiramente eficaz, completamente diverso da falida democracia representativa, que vê o mandato político como um bill de indenidades. A "limpeza das elites" e a saída de "aproveitadores do sistema e mesmo ladrões", referidas pelo sociólogo francês, por óbvio, precisa resultar em um modelo em que a ética seja preponderante, caso contrário, nada irá mudar. Vícios privados não trazem só benefícios públicos, mas vícios públicos talvez sejam ainda mais destrutivos que a fórmula de Mandeville.

A solução para as questões apresentadas não está propriamente no controle social, mas qualquer que seja o complexo modelo escolhido para suplantar o período de escassez que se segue à bonança artificialmente criada, certamente não poderá dispensar um controle social eficaz. No Brasil, não podemos continuar atirando ao lixo R \$ 234 bilhões a cada ano, nem fechar os olhos para a miséria que está ao nosso redor. Para isso é preciso vontade política para mudar, optando por um sistema de controles recíprocos capaz de suplantar um positivismo cego sem abandono da positividade do Direito. Como ensina o Prof. Adilson Dallari, "urge que o jurista e o julgador tenham mente aberta e sensível. Fácil é apor o anátema da inconstitucionalidade ao que sói inovador. Da tentação desse

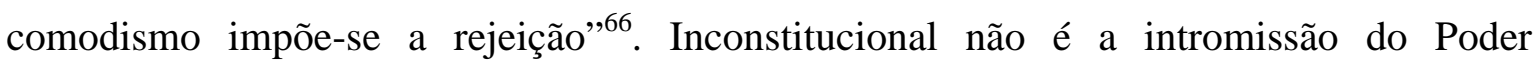
Judiciário e do Tribunal de Contas nos planos orçamentários, é a livre partilha de valores públicos, utilizados como moeda de troca na formação de maiorias não-representativas da vontade popular.

66 DALLARI, Adilson Abreu. Prefácio escrito para Estatuto da Cidade. São Paulo: Malheiros, 2002, p.19. 


\section{AGÊNCIAS REGULADORAS INDEPENDENTES E DEMOCRACIA. DÉFICIT DEMOCRÁTICO}

As complexas necessidades contemporâneas da vida pública reclamam drástica mudança no modelo estatal adotado. As salvaguardas, por exemplo, de exigência de licitação para as compras públicas, tornavam o Estado absolutamente ineficiente e incapaz para assumir serviços públicos essenciais. Imaginou-se, então, que a criação de empresas estatais e sociedades de economia mista, com personalidade de Direito Privado, pudesse realizar aquilo que a Administração Direta não conseguia, mas a estratégia não surtiu efeito, pois essas novas entidades continuavam, em muitos aspectos, a enfrentar as mesmas dificuldades experimentadas pelos órgãos públicos. O total controle exercido pelo poder central passou a determinar a ineficiência dessas entidades, que, cada vez mais, afastavamse do modelo gerencial privado para se tornar sucursais da Administração Direta e repositório de cargos de confiança, preenchidos com o único propósito de apadrinhar correligionários. A cada novo governo, as empresas do Estado passavam por uma total reformulação de conceitos e propósitos. Ninguém relacionado à Administração anterior poderia subsistir. Como é fácil perceber, a caça às bruxas não é feita somente aos ocupantes dos cargos de confiança mas à própria política implantada por esses servidores. Nesse viés, seria ingênuo supor que políticas de longa duração mantivessem uma continuidade mínima capaz de evitar uma descaracterização substancial. Demais disso, políticas setoriais podem ser facilmente mudadas, a título de correção de rumo, sem aparentemente se alterar a macropolítica que deu origem aos planos originais.

Decidiu-se, então, importar uma figura jurídica de grande prestígio em outros países: as agências reguladoras independentes, cujos dirigentes não ficam à mercê da autoridade do chefe do Executivo. Essa particularidade serve como uma espécie de blindagem contra os interesses imediatistas e eleitorais do governo. Com a autonomia assegurada, não há que se falar em temor reverencial ou em hierarquia. Entretanto, como demonstrou às escâncaras a crise no setor aéreo, a corrupção e a busca de prestígio político 
desviaram a atuação eficaz que se esperava dessas entidades. É que o poder corrompe e aquele que dele desfruta tende a abusar de suas prerrogativas. Entidades autônomas possuem, na prática, um poder difícil de controlar, uma vez que o Executivo encontra visíveis dificuldades para exigir das agências o cumprimento das políticas que engendrou. O Judiciário, via de regra, recusa-se a controlar atos que não são manifestamente ilegais, e que, exatamente por isso, estão imunizados pela couraça protetora da não-sindicabilidade do mérito do ato administrativo.

Apesar da providência do constituinte, que positivou o princípio da eficiência no art. 37 da Constituição Federal, o que permite, em tese, utilizar meios não considerados expressamente ilegais para alcançar fins específicos, as agências também pecaram pela ineficiência em razão da inexistência de meios de controle que, invariavelmente, se esboroam nas questões formais de competência.

Por outro lado, como as agências devem concretizar políticas públicas que têm seus recursos desviados para outros investimentos, as chances de sucesso continuam reduzidas. Maria Goretti Dal Bosco explica que:

\begin{abstract}
A questão, assim, é que o poder Executivo elabora um projeto orçamentário para desenvolver durante um ano, e um plano plurianual para outros quatro anos, mas não implementa boa parte dos investimentos previstos, ou, simplesmente, muda de rumos no decorrer do tempo. A exigência de vinculação à lei orçamentária, entretanto, acaba dissimulada, porque a Administração não deixa de aplicar os recursos nas áreas-chave, como no exemplo citado, da agricultura, mas comete desvios de rota no âmbito particularizado das políticas que atenderão projetos de reinserção de determinados setores aos programas de recuperação econômica, social e de desenvolvimento.

Esses desvios de rota na efetivação de políticas públicas pela Administração devem-se, entre outras, basicamente a duas razões: o descompromisso com a eficiência da prestação pública e os altos índices de corrupção presentes em muitas das práticas administrativas. Para isso, concorre a falta de maior fiscalização da sociedade através de mecanismos de controle, pois, em regra, estes implicam queixar-se às autoridades, ou ao representante do Ministério Público, ou às entidades associativas, organizações sociais, as quais, nem sempre, estão devidamente organizadas para realizar tarefas de defesa de direitos de seus associados. ${ }^{67}$
\end{abstract}

A autora, que é membro da Transparência Brasil (filiada à Transparency International), entidade de combate à corrupção na Administração Pública, ao se referir ao exemplo que citou em seu trabalho, está falando do Plano Nacional de Reforma Agrária (PNRA), que, ao ser anunciado em fins de 2003, previu a garantia de acesso à terra para

67 BOSCO, Maria Goretti Dal. Discricionariedade em políticas públicas. Curitiba: Juruá, 2007, p. 312-313. 
um milhão de famílias até o ano de 2006, mas notícias publicadas em jornais relatam que apenas cerca de 4 mil famílias foram assentadas.

Não é nossa intenção fazer denúncias nem criticar posições político-partidárias do governo, atemo-nos somente à análise objetiva dos fatos. No desvio relatado, que determinou drásticas mudanças na execução de políticas públicas (no caso, políticas de Estado), as alterações podem, por várias razões, ter sido imprescindíveis. Sucede, no entanto, que essas mudanças de rota ficam na dependência do exclusivo arbítrio do Executivo, que não é obrigado a prestar contas a ninguém.

A autora constata que a insuficiência da fiscalização da sociedade por meio de mecanismos de controle deve-se, também, à falta de condições técnicas das autoridades, do Ministério Público e das organizações sociais para exercer um controle eficaz. A crítica é pertinente, pois parece pouco provável que essas instituições estejam habilitadas para perceber a dissimulação que costuma ocorrer no sutil desvio de verbas aplicadas dentro do mesmo setor-chave. A denúncia das entidades sociais, em virtude da sua absoluta generalidade, torna-se vazia e manifestamente ideológica, ainda que possa ter um fundo de verdade. Como a dissimulação só será confirmada mais tarde, quando os números do governo forem publicados, o controle social é de completa inoperância. De qualquer forma, o que se deve enfatizar é que o interesse público teria sido mais bem atendido se o controle fosse capaz de perceber a dissimulação e o rodízio de verbas na flagrância dos fatos. Cada vez mais, torna-se preferível corrigir (a tempo) a punir. Quando a falta administrativa é praticada pelo governo na implantação de políticas públicas, as sanções são compensações desprezíveis em relação aos imensos danos que a solução de continuidade dos programas sociais ocasiona.

Como os únicos atores envolvidos no remanejamento de verbas, o Legislativo e o Executivo, estão unidos na estratégia de manter uma maioria, e a sociedade não possui meios técnicos para perceber a artimanha, torna-se evidente que o único poder neutral habilitado para o controle é o Tribunal de Contas, que, em se manifestando, abriria à sociedade a possibilidade de se opor ao caminho pouco ortodoxo e excepcional do remanejamento de verbas. Por isso que no Capítulo 8, ao tratar do controle do orçamento, a tese propõe a participação do Tribunal de Contas em todas as fases das leis orçamentárias.

Ao lado da desejável autonomia das agências, enfatiza-se, de início, a existência de um déficit democrático a macular a sua atuação por causa da ausência de segmentos da sociedade com possibilidade de acesso aos processos internos que resultam na implantação de políticas públicas. Isso só será contornado com ampla publicidade dos trâmites mais 
importantes do processo deliberativo. Evidentemente, ainda aqui, aplica-se o cerne desta tese, que é o controle social feito com o auxílio do Tribunal de Contas e do Judiciário, com o conseqüente desenvolvimento de uma cidadania atuante e colaboradora.

\subsection{O PODER NORMATIVO DAS AGÊNCIAS E O PRINCÍPIO DA LEGALIDADE. DELEGAÇÃO DE PODERES. ATIVIDADE REGULATÓRIA}

O direito é uma cristalização da economia, célebre frase de Baudin, expressa bem a influência da economia nos ordenamentos jurídicos. Quando o Estado reconheceu a sua ineficiência para assumir, por si próprio, atividades econômicas, mas o setor privado mostrou-se demasiadamente egoísta para se preocupar com o interesse público, que não era visto senão como uma forma potencial de consumo, assumiu o chamado "modelo regulatório" de administração. A questão dos limites aceitáveis para a contínua convivência entre a intervenção e a retração do Estado surgiu mais acentuadamente no momento em que se percebeu que as privatizações só conseguiriam atrair o capital estrangeiro se delegassem funções quase-legislativas às agências reguladoras. A autonomia dessas entidades em relação ao poder político do governo era a condição exigida pelas empresas estrangeiras para aportar seu capital no Brasil.

O que, em tese, parecia tranqüilo tornou-se uma tumultuada convivência entre um sistema jurídico totalmente fundado no sacrossanto princípio da legalidade e uma imperiosa necessidade de renascer para um mundo novo, globalizado, no qual não há espaço para soberanias arrogantes, mas compartilhadas. Para assumir esse novo papel, sem se entregar às potências econômicas, era preciso responder as seguintes perguntas: “quanto" e "onde" deve o Estado intervir na economia? ${ }^{68}$ É fácil perceber que a resposta não é somente técnica, mas política, uma vez que ideológica. De qualquer forma, a concretização para esse projeto reside na contínua dependência dos efeitos da instável economia política mundial e na crescente necessidade de colocar-se ao abrigo dessas influências.

Assumir um lugar no mercado internacional globalizado e regionalizado exige tomadas de decisão rapidíssimas e provoca uma constante tensão entre a segurança e a efetividade do Direito. Dogmas que sustentam a pirâmide normativa, como o fetiche da lei,

68 NUSDEO, Fábio. Curso de economia: introdução ao direito econômico. São Paulo: RT, 1997, p. 247-248. 
por questões de segurança devem conviver com regulamentos que insistimos em não considerar autônomos. É preciso ceder e recuar, abrir e fechar, quase casuisticamente. Essa tolerância nos leva a aceitar o chamado "Direito paralelo", que é indesejável, mas desculpa as concessões feitas à deslegalização da economia. Como nossa formação jurídica não aceita essa informalidade, passamos a tolerar microssistemas de Direito paralelo, mantendo a ortodoxia do Direito codificado. Se o Direito é a cristalização da economia e a economia tem suas fundações no movimento, o Direito Econômico deve ser, igualmente, mutável. Por isso que o Direito é o produto conservador de direitos revolucionários. É aquele que torna possível a segurança jurídica necessária para manter sob controle a insegurança destes direitos. Quer isso dizer, em suma, que a legalidade deve conviver com a regulação, e a indelegabilidade de competências, com a delegação de poderes para editar atos "quaselegais". "Quase-legal” é um termo utilizado pela doutrina para tornar palatável a delegação de competências indelegáveis.

Repita-se, mais uma vez, que quanto mais se abre espaço para o regulamento autônomo, mais se torna necessária uma visão ortodoxa da legalidade.

Diogo de Figueiredo Moreira Neto afirma que:

\begin{abstract}
Com efeito, essa competência normativa atribuída às agências reguladoras é a chave de uma desejada atuação célere e flexível para a solução, em abstrato e em concreto, de questões em que predomina a escolha técnica, distanciada e isolada das disputas partidarizadas e dos complexos debates congressuais em que preponderam as escolhas abstratas político-administrativas, que são a arena de ação dos Parlamentos, e que depois se prolongam nas escolhas administrativas e abstratas, que prevalecem na ação dos órgãos burocráticos da Administração direta. $^{69}$
\end{abstract}

O ensinamento se ajusta como uma luva ao que se está querendo dizer. A delegação normativa feita às agências é uma necessidade que não tem como não ser tolerada porque elas podem fazer o que Estado sabe que não consegue realizar. As escolhas abstratas e concretas das agências são o catalisador das competências que lhes são concedidas e toleradas. É evidente que o segredo para o equilíbrio está na delegação formal de poderes e na delegação implícita de competências, pois só a delegação ortodoxa de poderes engessa a economia e a só delegação implícita torna móveis as competências. Por isso dissemos que é preciso ser ortodoxo e revolucionário ao mesmo tempo, como uma forma de mal menor.

69 MOREIRA NETO, Diogo de Figueiredo. Mutações do direito administrativo. Rio de Janeiro: Renovar, 2000, p. 162. 
É nesse clima que a delegação de poderes normativos às agências reguladoras independentes deve ser apreciada. Se aceitarmos que há um fundo de verdade nessas afirmações, também seremos obrigados a aceitar e procurar novas formas de controle, sem agredir o sistema constitucional, mas retirando de seu texto tudo o que for preciso.

Assim, o princípio da legalidade torna-se cada vez mais imperativo. Essa situação paradoxal foi notada pela professora da Universidade de Paris I Mireille Delmas-Marty:

\begin{abstract}
Essa construção pode parecer paradoxal no domínio econômico onde a palavra de ordem é "desregulamentação". Mas é uma ilusão semântica julgar que a desregulamentação é o inverso de regulamentação. Na realidade, é o desdobrar das normas segundo outros dispositivos, de incitamento, de negociação, de flexibilidade (com normas temporárias, evolutivas, reversíveis), ou mesmo de auto-regulamentação. Ora, essa mesma flexibilidade favorece o risco de proliferações. Tanto mais que esse direito flexível nem sempre substitui o "direito rígido" com base nas interdições, na rigidez e nas sanções; em muitos casos, sobrepõe-se a este. (...) Essa sobreposição constitui o "paradoxo do flexível", 70
\end{abstract}

José Eduardo Faria também se manifesta sobre o assunto que se coloca como passagem obrigatória do entendimento da legalidade, do regulamento, da competência exaustivamente delineada na Constituição formal e da competência móvel entrevista pela Constituição real:

\begin{abstract}
Enquanto a concepção de sistema jurídico forjada pelo Estado liberal clássico faz da completude, da coerência formal e da logicidade interna de corolários básicos da ordem jurídico-positiva, esse emergente sistema normativo sob a forma de "rede" se destaca pela multiplicidade de suas regras, pela variabilidade de suas fontes e, principalmente, pela provisoriedade de suas estruturas normativas, que são quase sempre parciais, mutáveis e contingenciais. ${ }^{71}$
\end{abstract}

A criação de entidades dotadas de poder normativo, que acabaram por constituir uma verdadeira Administração autônoma e desvinculada do poder político central, provocou a rápida superação da tripartição absoluta de poderes e a transformação da pirâmide jurídica em verdadeira torre de Babel. O novo entendimento sobre o significado do princípio da legalidade passou, então, a impedir a idéia abstrata de que toda ação administrativa deve aninhar-se com precisão em alguma hipótese normativa editada pelo Parlamento. Esse confuso quadro apresentava a concepção estrutural estática e acadêmica

70 DELMAS-MARTY, Mireille. Apud MOREIRA, Egon Bockmann; SOARES JR., Lauro Antonio Nogueira. Regulação econômica e democracia: a questão das agências administrativas independentes. In: BINENBOJM, Gustavo (Coord.). Agências reguladoras e democracia. Rio de Janeiro: Lúmen Júris, 2006, p. 189.

71 FARIA, José Eduardo. Direito e globalização econômica: implicações e perspectivas. São Paulo: Malheiros, 1998, p. 8. 
de nossa Constituição rígida e a pintura dinâmica do Direito norte-americano. No nosso sistema, a norma é valorada pelo ordenamento, e a do norte-americano é legitimada pelo procedimento. Pode-se imaginar que o atrito é inevitável. Para continuarmos fiéis ao Direito romano-germânico, procuramos legitimar a ação estatal pela sua adequação abstrata com a Constituição. Quando queremos falar sobre interpretação constitucional, falamos em casos concretos que são, abstratamente, utilizados para sustentar um ponto de vista. Nesse sentido, como é costume dizer, a Constituição é aquilo que o Supremo Tribunal Federal diz ser.

Com essa massa de moldar, a legitimação pela Constituição é feita de maneira abstrata, desvinculada da legitimação dinâmica que a vida real provoca. Isso faz com que, ao contrário da legitimação pelo procedimento, o Direito esteja sempre aquém da vida real. É que a abstração escamoteia todas as dificuldades e impede a aferição da eficiência das políticas públicas. Verifica-se, a posteriori, a eficácia da escolha, mas a eficiência é analisada somente para explicar as causas do resultado, e isso significa que o caminho para o resultado, certo ou errado, é uma profissão de fé, pois não pode ser corrigido a tempo para sanar desvios substanciais. O fracasso, as falcatruas, a inoperância e o desperdício anual, como os R $\$ 234$ bilhões referidos no capítulo anterior, acabam sendo apenas dados estatísticos e história político-econômica.

A plausibilidade de modelos organizacionais que caracterizam o chamado Estadorede pressupõe, antes da nova visão de descentralização decisional, a atribuição de algumas competências normativas ausentes que compõem a rede, como as agências reguladoras. Desse modo, em tese se estaria transferindo competências não exatamente para o Executivo, mas para entidades autônomas criadas pelo Executivo. Estamos falando de autonomia política, que empresta estabilidade a regras que atingem o mercado e o consumidor. No Brasil, as agências reguladoras têm poder suficiente para implementar políticas restritas ao setor.

Em relação ao princípio da legalidade, seria compatível a ausência de controles vindo do Executivo e a implementação das políticas do setor, que, obviamente, não são formuladas pela agência, mas pelo Executivo? Mais, autonomia técnica, extremamente relevante, é compatível com os critérios políticos dos planos estatais?

A resposta nos dá Luiza Torchia:

O direito que buscava sua cientificidade na permanência dos fenômenos e na predefinição dos conflitos é substituído por um direito como saber problemático, 
em que a descoberta da melhor solução a priori é substituída pela pesquisa norteada pela lógica da compatibilidade e da adequação. ${ }^{72}$

É preciso lembrar, no entanto, que estamos tratando do demasiado e do muito pouco, de busca de soluções, com todos os riscos inerentes a tentativas e erros. O demasiado, com certeza, é pior que o muito pouco, por isso o alerta que nos vem à mente é a terrível advertência de Dante: "non t'inganni l'ampiezza di entrare”. Como o genial florentino advertiu, é larga a porta da perdição, do engano, das proposições imoderadas, das posições extremas, das doutrinas inflexíveis, dos pesos de valores absolutos.

Realmente, tratando-se, como é o caso, de resoluções que afetam milhões de pessoas, é preciso considerar que os riscos recomendam prudência, mas não imobilismo. Não se deve dizer que poderia ocorrer, na delegação de poder normativo ao Tribunal de Contas e a órgãos independentes, um inevitável déficit democrático pela cessão de parte da competência do Legislativo ao Executivo. A relação entre legalidade, legitimidade, economicidade e eficácia das políticas é muito mais complexa do que se supunha. A legalidade, tomada como princípio, concorre com outros princípios, para compor uma relação harmônica, em que todos sejam observados, em maior ou menor grau. Pensamos que hierarquizar princípios não é atribuir preponderância a nenhum deles, é hierarquizar valores aplicáveis ao caso concreto.

O peso que possuem, e os caracteriza, é que deve oscilar para proteger o valor mais relevante. $\mathrm{O}$ da legalidade, especificamente, não está em crise, nem tende a perder a sua importância. Trata-se, simplesmente, de retirar-lhe o excesso do absoluto.

O Direito moderno apenas determina que seja aplicado em harmônica interação com inúmeros outros valores, para constituir, o mais próximo possível, uma relação de valores em que um princípio não anula o outro, ainda que, em uma dada realidade, uns serão mais relevantes que outros. Nessa equação, pode acontecer de o princípio da legalidade ser suplantado por outro valor que melhor permita a realização dos desígnios constitucionais, como o da segurança jurídica e o da confiança legítima. Não vemos isso como perigo incontrolável, pois, como disse Paulo Bonavides,

quanto mais a lei se dessacraliza e fica minguante com a erosão de sua legitimidade, mais cresce e pontifica a Constituição, sede maior da nova legitimidade, e que desempenha o sumo papel de inspiradora, ordenadora e diretora de todo o ordenamento jurídico. A Constituição é cada vez mais, num consenso que se vai cristalizando, a morada da justiça, da liberdade, dos poderes

72 TORCHIA, Luiza. La scienza del diritto amministrativo. Rivista Trimestrale di Diritto Pubblico, n. 4, p. 1116-1131, 2001. 
legítimos, o paço dos direitos fundamentais, portanto, a casa dos princípios, a sede da soberania. A época constitucional que vivemos é a dos direitos fundamentais que sucede a época da separação dos poderes. ${ }^{73}$

Veja-se que, quando a lei cede passo a outro ato normativo, o que avulta é a Constituição. Não se pode falar, pois, em déficit democrático, pois o ato normativo que passa a regular o que era missão da lei só é editado para resguardar valores constitucionais. Não é o ato normativo inferior que suplanta a lei, é a Constituição que ocupa o vazio deixado pela retração do Parlamento, que não pode, mesmo, acompanhar a urgência da incisão cirúrgica reclamada pela complexa vida do mundo atual.

Nessa mesma obra, Paulo Bonavides traz o ensinamento de Zagrebelski, no sentido de que

\begin{abstract}
duas são as condições da Justiça Constitucional: uma, de caráter jurídico-formal, outra, de caráter político-substancial, cifrada no pluralismo das forças constitucionais; a primeira, teórica, a segunda, pragmática. A primeira é aquela em que, a nosso ver, avultam, de imediato, considerações acerca do declínio formal da lei, cujo lugar preeminente, em termos jurídicos formais, entra a ser ocupado pela Constituição. ${ }^{74}$
\end{abstract}

De qualquer forma, é de se reconhecer que o Executivo não usurpou parte da competência do Parlamento, posto que a lei deseja essa deslegalização. O exercício de funções normativas pelo Poder Executivo decorre de uma rapidez que o trâmite legislativo não possui e que Eros Grau chama de "capacidade normativa de conjuntura". Ela decorre implicitamente da Constituição Federal, pois, se o constituinte originário não reconhecesse a relevância da participação do Executivo na promoção de normas, não teria permitido a edição de medidas provisórias com força de lei.

É evidente que o exercício de funções normativas pelo Poder Executivo torna imprecisa e borrada a lei que estabelece os limites toleráveis da competência que pode ostentar - nesse exato sentido, é possível falar de escala móvel de competência, ditada pela necessidade -, mas é de se reconhecer que o Poder Legislativo pode estabelecer regras para limitar e aparar excessos, exercendo, efetivamente, a sua própria competência.

Ademais, eventuais abusos por parte do Executivo, como aconteceu recentemente na desmedida edição de medidas provisórias, não afastam o motivo pelo qual a delegação normativa foi concedida. Fábio Konder Comparato, reconhecendo essa específica

73 BONAVIDES, Paulo. Jurisdição constitucional e legitimidade. In: Estudos Avançados, USP, n. 51, maio/ago. 2004, p. 127.

74 BONAVIDES, Paulo. Jurisdição constitucional e legitimidade. Estudos Avançados, v. 18, n. 51, ago. 2004, p. 127. 
estratégia de produção de normas, esclarece que o governo apresenta também um sentido material:

\begin{abstract}
Acontece que não foi apenas pela forma de governar que o Estado contemporâneo reforçou os poderes do ramo executivo. Foi também pelo conteúdo da própria ação governamental. Doravante e sempre mais, em todos os países, governar não significa tão-só a administração do presente, isto é, a gestão de fatos conjunturais, mas também e sobretudo o planejamento do futuro, pelo estabelecimento de políticas de longo prazo. ${ }^{75}$
\end{abstract}

Mesmo assim, os limites da delegação não podem ser arbitrariamente negados pelo Legislativo, porque o interesse público no perfeito funcionamento da Administração e da economia nacional não se compraz com a clássica afirmação da tripartição de poderes e a obrigatória intervenção dos representantes eleitos pelo povo na edição de normas que irão reger a sociedade.

Como a Casa das Leis não tem capacidade material para suprir as complexas necessidades normativas do país, pensar que o Executivo é mero cumpridor da lei parece ser irrisão, porque por trás da questão teórica dos limites da competência normativa surge, em todo o seu esplendor e importância, o problema do funcionamento político do Estado e o dever de estabelecer políticas públicas. A título de exemplo, podemos citar medidas técnicas de saneamento, saúde e economia que devem ser tomadas na urgência flagrante dos fatos que requerem a pronta resposta governamental. Além disso, tais medidas seriam absolutamente inócuas se não veiculassem penalidades impostas à sociedade, daí a inevitável concessão de poderes mais amplos ao Executivo e a órgãos independentes que realmente alcançam a esfera íntima dos cidadãos.

Evidentemente, excessos acontecem, como nos planos econômicos, notadamente nos Governos Collor e Sarney. Nesse sentido, é oportuno o ensinamento de Rui Barbosa, que demonstrava visão bastante adiantada para sua época: "Se contestássemos a existência da delegação e sua validade, em nome de uma doutrina abstrata, daríamos por terra com a construção de nosso direito administrativo quase todo". ${ }^{76}$

75 COMPARATO, Fábio Konder. Para viver a democracia. São Paulo: Brasiliense, 1989, p. 102.

76 Disponível em: <http://www.mp.mg.gov.br/extranet/visao/diariooficial/repositorio/2005/20050701.doc>. Acesso em: 28 nov. 2008. 
5

\section{POLÍTICAS PÚBLICAS. CONCEITO JURÍDICO E POLÍTICO}

Como foi dito nos capítulos anteriores, se o homem, a sociedade, a relação entre os Estados, as necessidades, a economia, o Direito e, finalmente, a Constituição passaram por profundas alterações, é ingênuo supor que o sistema normativo vigente possa reger figuras jurídicas que são a imperfeita tentativa de regulação de categorias que não são propriamente jurídicas, pois pertencem à política e à administração pública. Por isso que talvez não haja um conceito jurídico de políticas públicas. O que pode haver, salvo melhor juízo, são métodos jurídicos capazes de objetivar a forma como dados políticos, sociais e econômicos devem ser apreendidos pelo Executivo e pelo Legislativo para conformar projetos de governo e de Estado. Reconhecer esses dados, avaliá-los, criar programas que tratem das mais variadas necessidades públicas e traduzir o produto de tudo isso na forma de expressões jurídicas não é tarefa exclusiva de nenhum dos Poderes de Estado.

Por isso dissemos que políticas públicas não são, em verdade, institutos jurídicos. Nessa difícil normatização, o produto final não se ajusta com perfeição nem à categoria das regras de Direito, nem aos princípios jurídicos. A doutrina aceita esse terceiro gênero de normas como policies.

Maria Paula Dallari Bucci, uma das primeiras a se debruçar sobre o assunto, naturalmente depois de Fábio Konder Comparato, ${ }^{77}$ sintetiza a questão da seguinte maneira:

\footnotetext{
Uma política pública carrega, necessariamente, elementos estranhos às ferramentas conceituais jurídicas, tais como os dados econômicos, históricos e sociais de determinada realidade que o Poder Público visa atingir por meio de programa de ação.

O jurista deve percebê-los, reconhecê-los e traduzi-los para o universo conceitual do direito, o que caberia no espaço epistemológico da teoria geral do direito. Essa, contudo, tradicionalmente trabalha o fenômeno jurídico a partir da norma posta, não antes. Daí que a direção de seu desenvolvimento são os métodos de interpretação, aplicação e, quando muito, construção do direito, a partir do direito positivo.
}

77 COMPARATO, Fábio Konder. Ensaio sobre o juízo de constitucionalidade de políticas públicas. Revista dos Tribunais, São Paulo, v. 737, p. 11-22, mar. 1997. 
Por outro lado, a contribuição da ciência política e da economia, e particularmente aquela que se ramifica na escola da análise econômica do direito, tem o mérito de jogar luz sobre a questão da escassez dos recursos para a realização dos direitos. Mas pertence a uma tradição estranha ao nosso ordenamento formalizado. ${ }^{78}$

Políticas públicas são microssistemas de Direito, integrados entre si, que obrigam, ao mesmo tempo, o legislador, o administrador, o juiz e a própria sociedade a concretizar princípios e programas, explícita ou implicitamente contidos no texto constitucional, para a efetiva legitimação de aspirações resultantes de projetos sociais ideológicos. Eles são a cristalização e a efetiva concretização de uma verdadeira realização do Estado. Nesse aspecto, a Constituição passa a ser considerada muito mais como estatuto político do que jurídico, já que determina fins capazes de transformar e moldar o Estado, não se limitando a fixar um estatuto organizatório de competências, limites e declarações abstratas de garantias e direitos fundamentais. Ela procura conformar um Estado novo, não fixar normas de regulação para um Estado existente. Como diz Canotilho,

finalmente, não há uma ordem natural, há uma ordem criada, conformada pelo homem, pela vontade do homem. E, mais do que isso, há uma ordem que se cria e que se vai projectar, porque não é uma ordem instantânea. A Constituição pode ser um momento, mas a ordem que se pretende criar (e as constituições diziam isso) aponta para o futuro e para as gerações futuras. ${ }^{79}$

\subsection{NORMAS-OBJETIVO, NORMAS PROGRAMÁTICAS E PRINCÍPIOS}

Há três espécies de normas, como gênero: princípios, regras e policies, que podem ser traduzidas como políticas ou diretrizes. A norma, como produção legislativa, caracteriza-se pela sua generalidade e abstração. As políticas, ao contrário, concretizam princípios e regras para alcançar objetivos determinados e concretos e podem ser implementadas com a edição de normas-regras, isto é, de normas de conduta e de organização.

Não são, no entanto, conceitos que devem ser posteriormente concretizados. A norma-objetivo é um novo tipo de norma que já traz, em si, a própria concreção objetivada. A norma-regra é aplicada com base em um "tudo ou nada", por isso não possui peso, como os princípios, que não podem excluir-se mutuamente e possuem um altíssimo grau de

78 BUCCI, Maria Paula Dallari. O conceito de política pública em direito. In: BUCCI, Maria Paula Dallari (Org.). Políticas públicas: reflexões sobre o conceito jurídico. São Paulo: Saraiva, 2006, p. 46.

79 CANOTILHO, José Joaquim Gomes. Canotilho e a constituição dirigente, p. 53. 
abstração. O elevado grau de abstração dos princípios é justamente o que os caracteriza e permite que sejam aplicados em inúmeras situações, com diferentes pesos.

As políticas não são aspirações programáticas, simples indicativos para o caminho a ser seguido, são ordens imperativas para buscar meios capazes de realizar fins previstos. Se não tivermos em mente o seu caráter revolucionário, não as poderemos entender senão como metas ou projetos, tão nobres em sua forma retórica quanto inúteis e desprovidos de significação em sua essência. Elas adquirem forma jurídica por meio de textos normativos que são dinamizados como instrumentos de governo e utilizam os direitos fundamentais para alcançar um prodígio: concretizar um elo, uma ponte, entre a política e o Direito.

Diogo de Figueiredo ${ }^{80}$ afirma que, depois de se trabalhar exaustivamente o ato administrativo e o vício do ato, passou-se ao vício do processo e, finalmente, com as políticas, ao vício de resultado, tendo em vista o dever jurídico constitucional de concretizar os direitos fundamentais. Nesse sentido, não somente a execução das políticas é imposta ao Estado, mas a sua própria formulação, porque, ante o extenso prazo necessário para implementação dos programas e a sua inafastável vinculação com os direitos fundamentais, a simples ameaça à sua efetivação pode e deve ser sindicada. A feição preventiva do controle a ser exercido sobre as políticas justifica-se em razão de que o gozo minimamente adequado aos direitos é vital para a cidadania e a democracia. Acresce dizer que, por tratarmos de macroeconomia, os prejuízos econômicos podem ser visualizados como causa eficiente da miséria e da fome endêmicas no país.

Eros Grau ensina que

O Direito passa a ser operacionalizado tendo em vista a implementação de
políticas públicas, políticas referidas a fins múltiplos e específicos. Pois a
definição dos fins dessas políticas é enunciada precisamente em textos
normativos que consubstanciam normas-objetivo e que, mercê disso, passam a
determinar os processos de interpretação do direito, reduzindo a amplitude da
moldura do texto e dos fatos, de modo que nela não cabem soluções que não
sejam absolutamente adequadas a tais normas-objetivo.

Esse autor refere-se à "moldura da norma", metáfora de Kelsen, acrescentando que se trata, ao mesmo tempo, de "moldura do texto" e "moldura dos fatos", pois o intérprete deve interpretar também o caso, além do texto. Em face da abstração e generalidade da

80 MOREIRA NETO, Diogo de Figueiredo Moreira. Novos horizontes para o direito administrativo: pelo controle das políticas Públicas. Ecos de um congresso: a próxima missão, p. 409.

81 GRAU, Eros Roberto. Ensaio e discurso sobre a interpretação/aplicação do direito. 3. ed. São Paulo: Malheiros, 2005, p. 41. 
norma, a produção da norma (concreta) aplicável a cada caso será sempre uma nova solução.

As normas programáticas seguem um critério de efetividade e, segundo José Afonso da Silva, são aquelas

\begin{abstract}
através das quais o constituinte, em vez de regular, direta e imediatamente, determinados interesses, limitou-se a traçar-lhes os princípios para serem cumpridos pelos seus órgãos (legislativos, executivos, jurisdicionais e administrativos), como programas das respectivas atividades, visando à realização dos fins sociais do Estado. ${ }^{82}$
\end{abstract}

Normas-objetivo, ao contrário, encerram um conteúdo materialmente finalístico. Os dois conceitos podem coexistir, mas somente a norma-objetivo pode ser identificada por uma causa final.

\title{
5.2 NORMA COMO MODELO FINALÍSTICO E O ESTADO DIRIGENTE. O PARADIGMA DOS DIREITOS SOCIAIS EXIGE PRESTAÇÕES POSITIVAS DO ESTADO. SANÇÕES E CONTROLE POPULAR
}

Tratando das formas de validade da norma, dissemos que somente a norma-objetivo pode ser identificada por uma causa final. Nesse caso, quem assume os fins assume também os meios, que, se inexistentes, devem ser criados. Em todos os outros, quem assume os meios não tem responsabilidade pelos fins, só pelo efetivo cumprimento dos meios, ainda que o seu horizonte seja um fim determinado.

O que importa ressaltar é que a norma como modelo finalístico valida as normas subseqüentes se estas apresentarem em relação àquela uma solidariedade entre fins e meios, e suscita questões de validade específicos, não genéricos. As normas como modelo condicional, ao revés, vinculam as normas subseqüentes em relação aos meios que tornaram obrigatórios, independentemente de os fins condicionados serem ou não alcançados.

O Estado dirigente, intervencionista, exige para a eficácia de sua ação um modelo jurídico específico, que é o Direito das políticas públicas. A derruição dos grandes sistemas, assim como aconteceu no surgimento do microssistema do Direito do Consumidor, proporciona subsistemas de extrema especialização, que requerem interpretação e produção de normas diferentes do ordenamento geral. Isso não significa,

82 SILVA, José Afonso da. Curso de direito constitucional positivo. 6. ed. São Paulo: RT, 1990, p. 444. 
absolutamente, quebra de unidade orgânica e harmônica do sistema. Ocorre, como ressalta Cláudia Lima Marques, ${ }^{83}$ o fenômeno do diálogo das fontes, teoria segundo a qual todos os ramos do Direito são aplicáveis, ao mesmo tempo, sobre determinado caso, havendo logicamente - normas que são de aplicação subsidiária em relação a outras.

A moderna prática administrativa e a ampliação da gestão do Estado caracterizamse, segundo Habermas,

\begin{abstract}
por um elevado grau de complexidade, dependência conjuntural e incerteza que não pode ser inteiramente antecipada pelo legislativo e, conseqüentemente, determinada no nível normativo. O tipo clássico de norma jurídica em larga medida se dissolve, pois ele consiste em um programa condicional que define ofensas listando as condições sob as quais o Estado está autorizado a intervir e as conseqüências jurídicas nas quais se estipulam as medidas que o Estado pode adotar. Percebe-se que o ato normativo passa a agregar formas normativas especiais, incluindo legislações especiais, leis temporárias experimentais e diretivas regulatórias abrangentes, com reflexos evidentes no aspecto funcional da separação de poderes. Constata-se a norma jurídica instrumentalizada sob novo viés, a serviço da realização dos objetivos de políticas. Note-se que a política pública funciona numa dimensão diferente da norma tradicional estruturada sobre a coerção. ${ }^{84}$
\end{abstract}

As normas que veiculam objetivos são, realmente, uma inovação no sistema normativo, mas não por não estarem conformadas na tradicional idéia de norma-sanção. A sanção não é elemento da norma, não é de sua essência, pois a juridicidade não está ligada a sua impositividade e a sanções específicas, é elemento de sua vinculação formal ao sistema jurídico, como bem observa Charles Albert Morand. ${ }^{85}$

A ausência de sanção específica, ademais, é característica das normas constitucionais, que nem por isso deixariam de ser normas jurídicas. Tal como no Direito Constitucional, as normas que estabelecem políticas públicas possuem uma sanção indireta que consiste na crítica e na pressão popular, de natureza obviamente política. A eficácia desse tipo de sanção reside exatamente na publicidade que se der ao descumprimento dos programas e no grau de comprometimento que a sociedade tem como a cidadania de seus membros. Parece mais que evidente que, sem a participação popular na fiscalização das políticas, as normas-objetivo estariam, aí sim, destituídas de qualquer sanção.

83 MARQUES, Cláudia Lima. Superação das antinomias pelo diálogo das fontes: o modelo brasileiro de coexistência entre o Código de Defesa do Consumidor e o Código Civil de 2002. Revista da Esmese, n. 7 , p. 15-54, 2004 - Doutrina.

84 Apud MASSA-ARZABE, Patrícia Helena. Dimensão jurídica das políticas públicas. In: BUCCI, Maria Paula Dallari (Org.). Políticas públicas: reflexão sobre o conceito jurídico. São Paulo: Saraiva, 2006, p. 56-57.

85 MORAND, Charles Albert. Apud GRAU, Eros Roberto. Notas sobre a noção de norma-objeto, p. 146. 


\section{3 “GOVERNANCE” E POLÍTICAS PÚBLICAS}

A exata relação entre a efetividade - pode-se até dizer validade - de políticas públicas e o controle social é a mesma que existe entre Estado e sociedade e entre governo como instituição e governo como processo. Alan Hunt, referindo-se à doutrina angloamericana de "governance", esclarece o sentido do vocábulo governança, que está umbilicalmente ligado ao processo de governar, não ao ato de governar ou à instituição de governo:

\footnotetext{
O foco em "governança" abre um espaço que nos permite pensar em governo mais como processo do que como instituição e romper com os hábitos de há muito instilados pela dominância da nação-Estado de que apenas governos governam. O termo "governança" ajuda-nos a focalizar as muitas dimensões da experiência e das consequiências de ser governado (...) Colocando em termos diferentes, esta concepção de governança trespassa a distinção entre Estado e sociedade civil; é de ser achada em ambos os lados, e não apenas um deles, minando a equação do senso comum de governo com imposição externa ou vertical. $^{86}$
}

O tema é de extrema importância, mas prende-se diretamente a um estudo mais aprofundado de políticas públicas e de formas democráticas de Estado. Escapa, desse modo, ao limite das competências do Tribunal de Contas. Reconhecemos na Corte de Contas a sua vocação para auxiliar a sociedade no controle social de políticas e do orçamento, mas ela não pode ser tão ampla a ponto de forçar uma aproximação entre Estado e sociedade. O fundamento da tese está em que a competência do Tribunal, como órgão auxiliar da sociedade, resulta diretamente da competência que ele possui. Parece-nos que não há justificativa constitucional para legitimar ao Tribunal uma competência que não pertence nem mesmo à sociedade. Governança é opção política mais que desejável, mas é forma de governar, matéria essencialmente política, que não adquire foros de impositividade em face do texto constitucional. Evidentemente, mesmo aceitando a abertura da Constituição, isso não seria possível.

86 HUNT, Alan. Law as a constitutive mode of regulation. Apud MASSA-ARZABE, Patrícia Helena. Dimensão jurídica das políticas públicas, p. 58. 


\subsection{CONTROLE DAS POLÍticas PÚBLICAS. PARÂMETROS DE CONTROLE}

Um controle consistente de políticas públicas deve ser exercido em duas diferentes dimensões: a) identificação dos parâmetros de controle e b) fixação dos instrumentos de controle.

\section{a) Identificação dos parâmetros de controle}

São eles: parâmetros objetivos; resultados previstos; escolha das políticas. A identificação dos parâmetros de controle a partir do texto constitucional pode ser feita tendo em foco os parâmetros objetivos de controle, os resultados finais previstos e a própria escolha das políticas. Todos eles, inclusive o critério dos parâmetros objetivos, podem ser de difícil valoração. Apesar da clareza do disposto nos arts. 195, 198 e 212 da Constituição Federal, não se pode esquecer que as previsões rígidas são feitas para a normalidade das coisas, ou, pelo menos, para um raio de imutabilidade minimamente razoável. É evidente que o executor do orçamento não tem nenhuma discricionariedade sobre os limites previstos nos mencionados artigos da Constituição, nem pode alegar crises razoavelmente previsíveis para deixar de cumprir aqueles limites, mas sempre é possível imaginar situações graves que estarão totalmente fora do controle do administrador, por mais prudente que seja.

As previsões que fizemos na elaboração do projeto de tese, em 2007, infelizmente vieram a se confirmar com a ocorrência da grave crise nas bolsas internacionais e da recessão nos Estados Unidos e em diversos outros países. Esses fatos, que também comprometeram a economia interna do Brasil, por sua excepcionalidade, dão uma certa margem de manipulação na distribuição das verbas. Nesse caso, ainda seria possível falar em parâmetros objetivos que não admitem qualquer tipo de consideração razoável? É claro que não.

Consideramos que qualquer administrador está preso às previsões legais e constitucionais, mas está, igualmente, preso à conjuntura econômica, e se o estrito cumprimento das quotas constitucionais impedir, desproporcionalmente, a realização de interesses públicos urgentes e inadiáveis, configura-se um verdadeiro estado de exceção capaz de justificar a manipulação das verbas.

O primeiro campo de trabalho, apesar dessas considerações, não apresenta grandes problemas. 
O segundo parâmetro tem em vista o resultado final esperado. É de eficiência que se fala. Enquanto não forem alcançados os objetivos esperados, as políticas não podem ser paralisadas nem sofrerem atrasos injustificáveis. Em tese, se as mesmas dificuldades intransponíveis referidas estiverem presentes, políticas públicas menos importantes podem ter parte de suas verbas remanejadas para projetos prioritários. Mas qual o critério para definir prioridades? Aí reside a dificuldade. É um critério político? Pensamos tratar-se de uma opção política, condicionada por um critério que considere as consequiências concretas das inúmeras variáveis possíveis e atenda, minimamente, todas as políticas preteridas.

As políticas públicas são fundadas por normas-objetivo, que não são, exatamente, nem regras nem princípios. Elas não têm a mesma abstração e generalidade das regras e, muito menos, dos princípios. Aproximam-se das regras, só que apresentam peso como os princípios. Por não serem aplicadas na base do "tudo ou nada", como as regras, permitem uma ponderação, exatamente como os princípios, que dirá, no caso concreto, qual o peso atribuído a cada projeto. Em qualquer situação, é o interesse público que deve comandar o critério para sindicar a razoabilidade e a proporcionalidade da opção. Há, em tese, possibilidade de controle judicial.

Quanto à escolha das políticas, no terceiro parâmetro, a questão é visivelmente mais complicada, o que dificulta extremamente o controle judicial. O Tribunal de Contas pode ajudar nesse controle na análise que fizer da legitimidade da opção eleita, ou mesmo auxiliando o povo a exercer o controle social. Neste caso, é de eficácia que se trata.

\section{b) Fixação dos instrumentos de controle}

Se esses parâmetros relacionados não forem observados ou se inexistir um critério razoável para o remanejamento de verbas em caso de necessidade extrema - o que só pode ser valorado com a análise das mais completas informações acerca de receitas e despesas, bem como de projeções realistas para um determinado período -, quais as consequiências jurídicas? As penalidades previstas no ordenamento podem alcançar o administrador, responsabilizando-o pessoalmente, ou produzir conseqüências para o próprio Estado, como, por exemplo, ser proibido de gastar em publicidade governamental.

Também se pode pensar em, por meio do Judiciário, obrigar o Poder Público a corrigir as opções equivocadas e impor o investimento nas metas constitucionais 
prioritárias. De qualquer maneira, isto só seria possível com o auxílio do Tribunal de Contas.

\subsection{PRINCÍPIO DA EFICIÊNCIA. NÃO É UM PRINCÍPIO-CONDIÇÃO, MAS UM PRINCÍPIO-FIM}

A atividade da Administração, classicamente, sempre esteve submetida ao princípio da eficácia. Se os atos do Poder Público fossem, em tese, aptos a alcançar os fins a que se destinavam, independentemente do resultado, a ação estaria correta. Bastaria a aptidão para produzir o resultado esperado para o ato ser eficaz. Como se vê, o desvalor do resultado não importava, bastava a eficácia abstrata da decisão tomada pela Administração. Hoje, com a nova redação dada ao art. 37 da Constituição, exige-se um plus: a eficiência de seus atos. É evidente que, se o processo de tomada de decisão e o resultado produzido estão submetidos aos princípios da eficácia e da eficiência, o longo desenrolar da implantação da política pública também poderá ser sindicado, tanto porque a aparente eficácia inicial mostrou-se inexistente, como porque, mesmo eficaz, tornou-se ineficiente.

A eficiência da Administração refere-se não só aos resultados atingidos, mas também aos meios empregados para atingi-los. Esse ponto é de extrema importância para a tese, porque responde a algumas perguntas feitas no primeiro capítulo no que concerne à competência do Tribunal de Contas para a sua intromissão na política administrativa da ANAC e para as determinações feitas ao Ministério da Defesa, ao Ministério do Planejamento e à Casa Civil da Presidência da República. A competência do Tribunal de Contas decorreu, exatamente, da aparente ineficiência desses órgãos. No caso da ANAC, que foi o que mais celeuma criou, a preocupação da Corte ficou plenamente justificada com a eclosão da grave crise aérea por que passou, ou continua passando, a aviação civil brasileira.

Nesse sentido, o princípio da eficiência não é um princípio-condição, que impõe limites formais de competência, pois se apresenta como princípio-fim, consubstanciada que está a condição material de competência (resultado). 


\section{NORMAS DE COMPETÊNCIA}

Para averiguar como as normas de competência restringem ou alargam as atribuições das agências reguladoras ou de qualquer outro órgão estatal incumbido de implantar políticas públicas e, em decorrência, das instituições que exercem o controle externo, como o Tribunal de Contas, é preciso entender o sistema de repartição de poderes e competências para garantir à Administração o uso de seu indispensável poder discricionário, sem descurar da legitimidade dos meios empregados na consecução do bem comum delineado, de modo genérico, em lei formal. Em verdade, a relação entre legalidade, legitimidade e fins concretos objetivados na norma-objetivo (lei formal) só pode ser alcançada se precisamente entendido esse mecanismo.

O Estado, uma vez instituído e estruturado, distribui, entre seus inúmeros órgãos e agentes, as atribuições que lhes são conferidas pela Constituição. Desde a concepção clássica de Montesquieu da divisão de poderes, deixando claro que cada agente exerce o seu poder sem ingressar nos limites do outro, que o Estado vê-se repartido em estrutura burocrática com o objetivo de que cada um exerça a atividade que lhe compete, sem atritar com a de outro. Não bastando tal providência, de que o poder controle o poder, o ordenamento jurídico distribui, dentro de cada órgão, competências próprias. Então, vê-se que, além de haver a tripartição de poderes e a delimitação em respectivos órgãos, a estrutura funcional vem hierarquizada para que as atribuições possam ser bem e fielmente exercidas.

Divididas as funções do Estado entre os três Poderes, é essencial que, em cada estrutura, haja a divisão em órgãos e agentes, para que a máquina estatal passe a funcionar. Como assinala Celso Antônio, "há dois problemas que não se fundem e não têm por que serem fundidos. Um deles é o do querer e do agir do Estado; outro é o da repartição das atribuições em diferentes unidades". ${ }^{87}$ Invoca o autor o magistério de Marcello Caetano ao

87 MELLO, Celso Antônio Bandeira de. Apontamentos sobre agentes e órgãos públicos. São Paulo: RT, 1984, p. 66. 
definir o órgão como "elemento da pessoa coletiva que consiste num centro institucionalizado de poderes funcionais a ser exercido pelo indivíduo ou pelo colégio de indivíduos que nele estiverem providos, com o objetivo de exprimir a vontade juridicamente imputável a essa pessoa coletiva". ${ }^{8}$

Em conseqüência, é imprescindível a existência de um agente para dar voz e comando à unidade estrutural da Administração Pública e, de seu lado, há o plexo de atribuições outorgado, pela Constituição ou pela lei, àquela unidade funcional. Daí a concepção de Celso Antônio de que órgãos outra coisa não significam que "círculos de atribuições, os feixes individuais de poderes funcionais repartidos no interior da personalidade estatal e expressados através dos agentes neles providos". ${ }^{89}$

Separados e identificados os Poderes do Estado, têm eles que se manifestar e o fazem por meio dos agentes públicos investidos em cargos ou funções, e que, de outro lado, apenas podem emitir comandos e ordens se tiverem competência para tanto. Ver, a propósito, as lições de Cirne Lima ${ }^{90}$, Caio Tácito ${ }^{91}$, e de Regis Fernandes de Oliveira - no caso deste, por meio de uma citação:

\footnotetext{
Para que a Administração pública execute as finalidades que lhe foram atribuídas pelo ordenamento normativo, impõe-se que se valha de seus agentes. Estes, uma vez admitidos e providos nos cargos e funções, recebem uma esfera de atribuições. Quem fixa o âmbito delas é a lei. A soma de poderes e deveres jurídicos previstos na Constituição ou na lei, atribuída para que sejam buscados os interesses públicos albergados no sistema normativo, é a denominada competência. $^{92}$
}

A competência, assim, delimita o poder. Cada pessoa investida em determinado cargo ou função recebe um plexo de atribuições. A delimitação do poder do agente, que lhe é devolvido em exercício de competências previamente fixadas, destina-se a que ele atinja objetivos que são traçados pelo ordenamento normativo. Se o agente deixa de exercer a atribuição que lhe foi conferida ou se a exerce de forma a atingir objetivo diferente, ocorre desvio de poder.

Esses preceitos básicos, sob uma aparente imagem de simplicidade, escondem uma gama cada vez maior de dificuldades. A própria mudança das concepções de Estado, ditada pela radical transformação das necessidades sociais e econômicas, que demandam uma

88 CAETANO, Marcello. Manual de direito administrativo. 7. ed. Lisboa: Coimbra Editora, 1965, p. 154.

89 MELLO, Celso Antônio Bandeira de. Apontamentos sobre agentes e órgãos públicos, p. 69.

90 LIMA, Ruy Cirne. Princípios de direito administrativo. 5. ed. São Paulo: RT, p. 139.

91 CAIO TÁCITO. Abuso de poder administrativo. Rio de Janeiro: DASP/Instituto Brasileiro de Direito Administrativo, 1959, p. 27.

92 OLIVEIRA, Regis Fernandes de. Delegação administrativa. São Paulo: RT, 1986, p. 32. 
imediata resposta interventiva não só para ordenar o presente como para conformar o futuro, obriga a lei a delegar a órgãos do Executivo, de forma genérica, atribuições que em nada se assemelham à tradicional função de administrar a lei de ofício. Isso traz uma séria complicação àquilo que se apresentava tranqüilo: uma clara divisão de poderes e atribuição de competências.

O Direito, assim, mostrava-se certo e arrumado. No dizer de Diogo de Figueiredo,

\begin{abstract}
era racionalista, atendia à visão do positivismo Kelseniano, mas completamente impérvio àquilo que é a necessidade do homem, que é de viver no mundo de valores e realizá-los. Portanto, sem essa dimensão o direito se estiolava, se perdia, se multiplicava em normas, como dizia Enterría, e transformava-se num direito cheio e inçado de normas e de pouco valor, de pouca expressão. Há uma diferença entre compreender a ciência como representação objetiva do real e compreendê-la como uma maneira subjetiva de ver a realidade. O Direito como ciência não pode ser representação do real. O Direito como ciência tem que ser uma representação de nós, da maneira como nós vemos subjetivamente a realidade. E essa é a grande missão do Direito Contemporâneo, não é só do Constitucional, da Teoria da Norma, da Teoria do Direito. ${ }^{93}$
\end{abstract}

É verdade, a aplicação do Direito e, naturalmente, a interpretação que deve ser dada às normas que fixam competências devem levar em conta, em se tratando de políticas públicas, a nossa visão da realidade, posto que as ações exigidas pelo executor dos programas socioeconômicos só podem ser conhecidas em face das mutações ocorridas nos fatos e nas prognoses anteriormente feitas. Quer isso dizer que os prognósticos e mesmo as metas devem ser continuamente reajustados para acompanhar as inúmeras variantes que podem se modificar, de maneira drástica, em intervalos de tempo relativamente curtos na implantação dos programas. Ainda que qualquer norma editada pelo Parlamento possa ser considerada uma previsão do futuro, com o qual pretende amoldar-se, a concretude dos programas, ao revés, tem o precípuo objetivo de alterar o prognóstico que se faz do futuro. A sua ação não pode ser a resposta dada a uma representação objetiva do real, posto que exige uma contínua valoração da realidade. É dizer, não só novos meios devem ser encontrados para alcançar os objetivos predefinidos, como as próprias metas devem ser revistas, tendo em conta a relatividade das necessidades públicas, a disponibilidade de recursos presentes e futuros e a conseqüente reavaliação do peso que cada política apresenta quanto à totalidade da ação governamental, considerada como um todo.

93 MOREIRA NETO, Diogo de Figueiredo. A real interpretação da instituição Tribunal de Contas. Palestra proferida no Tribunal de Contas do Município do Rio de Janeiro, em 30/03/2001. Disponível em: <http://www.tcm.rj.gov.br/Noticias/232/Encontro.pdf>. Acesso em: 2 nov. 2008. 
Tem-se um porvir, não um devir. As previsões iniciais, que justificam as despesas públicas e as novas políticas, vão se alterando conforme novas variáveis são ajuntadas à equação socioeconômica contida no orçamento público. Essas alterações podem ser tão drásticas a ponto de desfigurarem por completo a peça orçamentária original. $\mathrm{O}$ executor do orçamento, tendo em vista a sua apreciação subjetiva das mutações incidentes sobre a realidade, pode ser considerado, de certa forma, como o verdadeiro autor do plano de gastos e investimentos. Nesse aspecto, as competências decisórias mais importantes da economia nacional ficam literalmente fora do alcance do Legislativo e de qualquer outro meio eficaz de controle. Por isso o Ministro Gilmar Mendes criticou o fato de estarmos "fazendo praticamente todo o Orçamento com medida provisória", e pontuou que isso se assemelha a uma "roleta russa com todas as balas do revólver". 94

A ordem interna tradicional das competências decisórias não se encontrava organizada em círculos concêntricos, estruturava-se escalonadamente, de forma que cada agente ou órgão sempre buscava sua atribuição na lei. Sucede, no entanto, que as novas figuras jurídicas instituídas na Administração moderna, como as agências reguladoras, a Receita Federal, o Banco Central e outros órgãos dotados de poder normativo, alteraram profundamente o arquétipo delineado no início deste capítulo e o fluxo entre o centro e os segmentos do poder. Imprimiram, também, a relação competência atribuída em lei-poderes implícitos de um nível de circularidade nunca antes imaginada. Nessa circularidade, influências recíprocas acabam por tornar a lei não um limite rígido de competências, mas uma imprecisa delimitadora de horizontes. O limite das atribuições postas na lei acompanha as oscilações da perene mutação constitucional, que projeta sua luz sobre escaninhos escuros, ao mesmo tempo em que enegrece sítios iluminados. Essas cambiantes deixam antever a fragilidade do quadro positivado abstratamente pelo legislador, que não pode prever desdobramentos futuros de situações e urgências insuspeitadas.

O poder normativo permitido ao Executivo, apesar disso, não rouba espaço ao Legislativo, uma vez que não mais existe competência legislativa que se possa dizer pura, no sentido de realizar, com exclusividade, a atividade normativa abstrata. Todos os Poderes, todos os órgãos, todos nós, enfim, somos intérpretes da Constituição. Mais que isso, todos somos instrumentos à disposição do Estado para realizar a construção de uma sociedade mais justa, mais humana, mais livre. Esse pluralismo explica o que Loewenstein quis dizer ao declarar que a finalidade, o telos, o motivo pelo qual a separação de poderes

94 O Estado de S. Paulo, p. A6, 4 nov. 2008. 
existe é a liberdade. A tripartição de poderes e toda forma de atribuição de competências não é um dogma, uma condição essencial da organização estatal, ante a qual tudo se dissipa, mas um princípio de garantia da liberdade. Ela não deve sua existência diretamente à necessidade de organizar o poder do Estado, pois essa organização só faz sentido se e enquanto indicar a melhor forma de preservar a liberdade. Existe para proteger as garantias individuais e coletivas por meio da composição harmônica dos Poderes e das atribuições conferidas aos seus órgãos.

A própria unidade do Estado é uma técnica para alcançar o bem comum. Na lição de Jean Paul Rossi, sobre a multiplicação de entes da Administração Pública, o Estado é uma referência, não o centro absoluto do estudo dos entes públicos, pois, se a sociedade é plural porque o homem também é plural, uma vez que assumimos, ao mesmo tempo, diferentes papéis na sociedade, o Estado também deve ser plural, corpo multifacetado composto de segmentos da sociedade, dos estados e dos municípios. Pluralismo, a nosso sentir, não quer dizer somente admissão de fontes múltiplas, mas aceitação de que essas fontes exerçam contínuo fluxo de influências na organização do Estado, na elaboração dos planos orçamentários e na efetiva forma como esses recursos acabam sendo realocados, não só pelo chefe do Executivo e seus ministros, mas por autoridades pertencentes a escalões inferiores e pela sociedade. A questão é bastante complexa, mas pode ser mais bem percebida se buscarmos o ensinamento de Gilles Deleuze e Félix Guattari, dois dos mais destacados filósofos contemporâneos. Observam eles que

\begin{abstract}
a hierarquia não é somente piramidal (como na organização escalonada): o escritório do chefe está tanto no fundo do corredor quanto no alto da torre. Em suma, tem-se a impressão de que a vida moderna não destituiu a segmentaridade, mas que ao contrário a endureceu singularmente. (...) Mais do que opor o segmentário e o centralizado, seria preciso então distinguir dois tipos de segmentaridade: uma "primitiva" e flexível, a outra "moderna" e dura. (...) Mas as sociedades com Estado se comportam como aparelhos de ressonância, enquanto que as primitivas as inibem. ${ }^{95}$
\end{abstract}

Essa afirmação é particularmente importante para um Direito Público moldado nos padrões do século passado, pois, ainda que não se possa recusar nos Estados pós-modernos a existência de tantos centros de poder, parece bastante evidente a imprescindibilidade de a sociedade comandar a ressonância de todos esses centros.

Esse é, em síntese, o motivo desta tese.

95 DELEUZE, Gilles; GUATTARI, Félix. Mil platôs: capitalismo e esquizofrenia. São Paulo: Editora 34, 1996, v. 3, p. 84-87. 
Nesse passo, vê-se que o momento dialógico entre Estado e sociedade tem a finalidade precípua de tornar viável a coexistência do poder centralizado com os poderes segmentários. É que não mais se sustenta a idéia de Poder Executivo unitário. Além das conhecidas discrepâncias entre a Administração e o poder político central e da ambigüidade encerrada na idéia de que a Administração possa ser, ao mesmo tempo, executora e neutra, conforme referido no item 2.4, é inegável que a Administração moderna é essencialmente policêntrica. As determinações de agências reguladoras independentes e de certos órgãos dependentes do poder político dominante, que sem dúvida são centros de poder por excelência, como o Conselho Monetário Nacional (CMN), o Banco Central do Brasil (BACEN), a Comissão de Valores Mobiliários (CVM), o Conselho Administrativo de Defesa Econômica (CADE) e a Receita Federal do Brasil, ressoam até mesmo com maior vibração que as emissões oriundas do poder central.

Os filósofos supramencionados sustentam que o centralizado não se opõe à segmentaridade, uma vez que ela

\footnotetext{
torna-se dura, na medida em que todos os centros ressoam, todos os buracos negros caem num ponto de acumulação - como um ponto de cruzamento em algum lugar atrás de todos os olhos. (...) O Estado central não se constituiu pela abolição de uma segmentaridade circular, mas por concentricidade dos círculos distintos ou por uma ressonância dos centros. ${ }^{96}$
}

Essa profusão de centros de poder remete a um centro de significância que abarca todos os círculos e alcança todos os segmentos, de modo a serem processados e recepcionados no exato ponto em que as emissões se cruzam. Se o Estado, por seus Poderes constituídos, tiver o poder de emitir a sua própria versão dos sons expedidos pelos segmentos, o Estado policêntrico será mera falácia. Por outro lado, se a autonomia dos centros não for avaliada em relação ao mandatário legitimamente eleito pelos mandantes, à viabilidade econômica, à necessidade social e ao conjunto das ações tomadas pelas ramificações do poder, a ressonância certamente não estará fluindo de modo equânime e proporcional, porque a legitimidade da iniciativa encontra justificativa na ordem de preferência de todas as ações consideradas essenciais para o interesse público.

Nesse exato sentido, de que a hierarquia não é só piramidal e de que os subsistemas (cada vez mais especializados) tendem a crescer proporcionalmente à complexidade da vida moderna, lembramos as lições de Jacques Chevallier sobre a "ruptura do monolitismo de uma Administração que evolui para a adoção de um modelo 'policêntrico',

96 DELEUZE, Gilles; GUATTARI, Félix. Mil platôs, p. 87. 
caracterizado pela coexistência de vários centros de decisão e de responsabilidade", ${ }^{97}$ de José Eduardo Faria, no sentido de que o Estado não pretende manter uma centralidade artificial e ultrapassada diante da pluralidade de interesses privados que devem ser regulados por decisões econômicas acordadas independentemente de seu poder de jurisdição, e de Vital Moreira, que argutamente salienta que o aparecimento de entes públicos autônomos constitui a "resposta necessária do moderno Estado social ao alargamento das suas tarefas. A autonomização de organismos administrativos é, portanto, uma conseqüência, em termos de diferenciação e especialização, da ampliação e diversificação das tarefas administrativas" $"$.

Sustentamos, diante desse quadro, que somente uma efetiva participação da sociedade pode legitimar a forma como são processadas as miríades de informações que provêm dos incontáveis centros de poder do Estado contemporâneo. A arborificação dos círculos interligados deve ser admitida pelo Estado como absolutamente inafastável, só lhe restando atuar como caixa de ressonância tanto para os poderes públicos quanto para os interesses privados.

\subsection{INTERPRETAÇÃO DAS NORMAS DE COMPETÊNCIA E ATRIBUIÇÕES DO TRIBUNAL DE CONTAS E DO JUDICIÁRIO}

Neste passo, já temos composto o cenário geral, com a cenografia do Direito vigente e os diálogos da tensão existente entre Constituição formal e Constituição real. O enredo, por enquanto, é um drama. De qualquer forma, a peça está em andamento e podemos imaginar, embalados pelo som maravilhoso dos enunciados constitucionais, que no próximo ato estaremos redimidos das amarras que nos prendem à ante-sala dos países desenvolvidos. É lógico que essa tarefa demanda muitas batalhas, mas a nossa modesta colaboração, como um grão de areia na vastidão do espaço, consiste em aproximar Estado e sociedade mediante uma ação esclarecedora do Tribunal de Contas direcionada à sociedade e ao Poder Judiciário. Seria inútil e vazia essa pretensão se não tivéssemos estabelecido as premissas que desenvolvemos nos capítulos anteriores.

Uma última digressão é indispensável para circunscrever e compreender o problema. Dizer que o controle deve ser interno e externo e fixar as competências com que

97 CHEVAlLIER, Jacques. Apud ARAGÃO, Alexandre Santos de. Agências reguladoras, p. 204.

98 MOREIRA, Vital. Administração autônoma e associações públicas. Coimbra: Editora Coimbra, 1997, p. 30-31. 
cada titular irá exercê-lo soa muito simples, mas pressupõe que se conheça a dificílima maneira pela qual a interação entre os Poderes pode ser feita, em que profundidade o tangenciamento entre o Direito Público e o Direito Privado estabelecerá prevalências tendo em vista a participação popular na Administração Pública -, e como poderá ser contornada a omissão do Poder Legislativo, que continua se furtando a fixar padrões atualizados de controle de gestão e a disciplinar as relações entre o público e o privado. Importa saber, também, como será possível alcançar uma equilibrada relação de interdependência entre os Poderes e um controle social capaz de programar e legitimar as ações estatais. Não se procura situar as competências em um plano previamente fixado para garantir reservas de poder político, nem para harmonizar relações estatais de entes independentes. Esses objetivos serão alcançados se os núcleos de poder forem dirigidos, em primeiro lugar, para promover a liberdade, como defendido por Loewenstein. Desse modo, a constatação de que o sistema não funciona porque o mérito do ato administrativo é considerado intocável merece imediata adequação ao novo modelo de relacionamento entre os Poderes e às novas exigências de efetividade das ações estatais.

Dando sequiência ao raciocínio até aqui desenvolvido, constatamos ser clássico o entendimento segundo o qual a competência fixada na Constituição, como é o caso das atribuições do Tribunal de Contas, "apresenta-se exaustiva e taxativa: dispositivo algum de lei, ordinária ou complementar (salvante, evidentemente, emenda à própria Constituição), poderá reduzir ou ampliar tal competência". ${ }^{99}$ Carlos Maximiliano, em obra clássica, também esclarece que a "competência não se presume". ${ }^{100}$

Apesar da precisão dos ensinamentos dos juristas supratranscritos, a cega aplicação das regras de competência a algumas hipóteses não previstas expressamente pelo ordenamento jurídico conduz a soluções iníquas, incongruentes e incompatíveis com o sistema. No julgamento da Rcl n. 2.138/DF, por exemplo, o Ministro Nelson Jobim fez referência ao voto do Ministro Eduardo Ribeiro, nos seguintes termos:

Se partíssemos do princípio de que todas as normas jurídicas que atribuem
competência hão de ser interpretadas estritamente, não se podendo sequer ter
como por elas abrangidas outras hipóteses que, por força de compreensão,
houvessem de sê-lo, a questão seria de facílimo deslinde, pois induvidoso não
existir, no texto constitucional, disposição que, expressamente, estabeleça ser
este Tribunal competente para a matéria. Não me parece, entretanto, que a
tradição do nosso direito e a jurisprudência do País placitem tal entendimento
(...) A interpretação compreensiva do texto constitucional, também em matéria

99 CARNEIRO, Athos Gusmão. Jurisdição e competência. 13. ed. São Paulo: Saraiva, 2004, p. 63.

100 MAXIMILIANO, Carlos. Hermenêutica. Rio de Janeiro: Forense, 2003, p. 216. 
de competência, tem sido uma constante na jurisprudência do STF e do judiciário nacional em geral. ${ }^{101}$

Essa interpretação compreensiva aplica-se a todo o sistema normativo, ainda que se trate de norma constitucional fixadora de competência. A regra de competência, como qualquer outra regra de Direito, é criada para regular os fatos que inspiraram o legislador, mas, principalmente, para regular as hipóteses que surgirão no futuro. Nesse sentido, o lúcido ensinamento de Castanheira Neves: a lei pode ser concebida como uma "decisão concreta de concretos casos jurídicos futuros". 102

A regra fixadora de competência, com muito mais razões, só pode ser concebida como um prognóstico da melhor maneira de distribuir justiça ou, no caso da Corte de Contas, de zelar para que o Estado consiga desenvolver suas atribuições com eficácia, eficiência e moralidade, bem como de promover a formação de uma consciência cívica que resulte em uma eficiente parceria com a sociedade no controle da coisa pública. Se não era possível, à época do constituinte de 1988, prever as relações possíveis entre o Estado e o setor privado, nem o Direito Público vigente àquele tempo poderia ser utilizado para reflexões prospectivas sobre hipóteses ainda insuspeitadas, é evidente que as regras que fixaram a competência do Tribunal de Contas não poderiam antever como o controle externo deveria ser, por ele, exercido no futuro. Consideramos, no entanto, que essa leitura não destoa do texto da Constituição, como se esse sentido sempre estivesse lá, esperando ser resgatado.

Shakespeare, somente para ilustrar o que se acabou de dizer, deve encerrar aspectos ainda desconhecidos, que só serão descobertos no futuro, tal como ocorreu após a primeira interpretação psicanalítica de sua obra. A obra em si, entretanto, não mudou, como enfatiza Joseph Raz, professor titular de filosofia do direito da Oxford University. ${ }^{103}$ Os monólogos não escritos de seus personagens é que adquirem valor, compõem um todo nunca completo e tornam inesgotável o círculo hermenêutico com a obra do autor.

Ninguém nega que Hamlet pode ser interpretado de uma maneira diferente após o conhecimento de teses psicanalíticas inexistentes ao tempo de Shakespeare. O que não era tido como importante nas interpretações shakesperianas passou a ser fundamental para o entendimento da obra, embora Shakespeare nada soubesse sobre as descobertas de Freud.

101 STF - Rcl n. 2.138/DF, Rel. Min. Nelson Jobim, DJ 17/09/2002. O voto do Min. Eduardo Ribeiro (Rcl n. 591) não está disponível no site do STF.

102 NEVES, Antonio Castanheira. Metodologia jurídica. Coimbra: Coimbra Editora, 1993, p. 147.

103 RAZ, Joseph. Interpretação sem restabelecimento. In: MARMOR, Andrei (Coord.). Direito $e$ interpretação. São Paulo: Martins Fontes, 2000, p. 235. 
Mas uma interpretação só pode recuperar o que já está lá, o que significa que o intérprete não pode tentar melhorar o texto ou, com o uso de impressões pessoais, emprestar-lhe um sentido não considerado universal. Os monólogos de Hamlet não foram alterados com a nova interpretação, apenas se pode questionar os motivos que o levaram a um determinado procedimento. A mudança da maneira como tratava Ofélia pode ter acontecido em razão de um complexo de Édipo, desconhecido até pelo autor, mas que sempre fez parte da personalidade de Hamlet. Veja-se que não há lugar para subjetivismos, pois ainda que não se possa ver as coisas a não ser com nossos próprios olhos, não seriam toleráveis impressões personalíssimas não aceitas pela comunidade científica.

Com a interpretação constitucional sucede o mesmo. Referimo-nos, nesse particular, às normas que definem competências. $\mathrm{O}$ que se extrai dessas normas sempre esteve lá, aquela não é feita contra legem nem para melhorar o texto. Assim como no Hamlet, o que não era conhecido ou não era considerado importante em 1988 passou a ser, igualmente, fundamental para o significado da obra do constituinte. Da mesma forma, o que era relevante em 1998 apresenta-se com roupagem completamente diversa em 2008, assim como, em pouco tempo, poderá sofrer novas e profundas modificações. As novas interpretações de Shakespeare não descaracterizaram sua obra, ao contrário, enriqueceramna. Nenhuma palavra foi aditada, suprimida ou alterada nos diálogos, assim como nenhuma mutilação foi feita no texto constitucional, que, no entanto, sofreu uma drástica mutação em seu sentido original.

Esse constante fluxo e refluxo entre a Constituição e a vida real, com todos os anseios, aspirações e necessidades do ser humano, confere-lhe a universalidade capaz de tirá-la do alto pedestal em que foi colocada e fazê-la nutrir e ser nutrida pela seiva regeneradora que circula entre ela e todas as normas existentes, positivadas ou não.

Quando lembramos que inexiste "nessun maggior dolore che ricordarsi del tempo felice nella miseria", estamos apenas expressando um estado de espírito relacionado com o contexto objeto de nossa alocução, quase sem procurar ver a imagem dos amantes de Verona, abraçados no turbilhão infernal. O que não foi dito por Dante junta-se à experiência de muitos outros autores e aos nossos próprios preconceitos e sentimentos para ajudar a explicar intensidades e particularidades próprias do caso sobre o qual queremos fazer referência e emitir alguma consideração ou juízo.

Alerta-se, no entanto, que não se pode sacar qualquer coisa do texto interpretado, como de uma caixinha mágica, porque interpretar uma norma jurídica é diferente de estabelecer impressões e reações livres em relação a um teste de Rorschach. Brian Bix, 
professor de Teoria Jurídica e Argumentação Jurídica do King's College, Universidade de Londres, lembra que a interpretação ou o significado de uma peça, assim como uma norma de Direito, já estão no seu texto, ao contrário do teste de borrões, em que o significado do padrão ainda não está no padrão. ${ }^{104}$ Evita-se, desse modo, tanto o valor meramente simbólico da Constituição quanto a contradição entre Direito e realidade, isto é, entre idealismo da Constituição e realidade nacional.

Quando ocorre a fusão dos horizontes do constituinte e do intérprete, fundem-se, na realidade, esses dois mundos diferentes (idealismo e realidade), mas sempre tendo em vista que a interpretação é uma aplicação ao presente de um prognóstico ideal e abstrato feito no passado. As discrepâncias devem ser aparadas para adequar o passado ao presente, sem desfigurar o sentido da obra original. Na interpretação dos dois mundos supra-referidos, também o intérprete deve admitir que os seus conceitos podem ser modificados pelo texto original - ou seja, o texto compreendido não pode tornar-se um texto novo porque a essência do texto não pode ser modificada, sob pena de transformar o intérprete em autor, ou co-autor, do texto. Ele não preenche vazios, completa lacunas, já que somente na aplicação da norma é que o abstrato da norma se confronta com a realidade dos fatos. $\mathrm{O}$ abstrato da norma só se relaciona com as previsíveis hipóteses conhecidas pelo legislador. É por isso que se diz que a norma é feita para a normalidade, não para o excepcional.

Corrigir os pressupostos aceitos pelo legislador, tidos como equivocados pelo intérprete das políticas públicas, transformaria o intérprete no verdadeiro legislador. Se assim fosse, os seus standards prevaleceriam sobre os do legislador. Qual a sua liberdade, então? Um exemplo vale mais que palavras, por isso questionamos o seguinte: o limite de velocidade fixado para uma rodovia em $120 \mathrm{~km}$ por hora pode ser revisto pelo Poder Judiciário se os pressupostos jurídicos ou de fato forem objetivamente errôneos ou irrazoáveis? O julgador não pode avaliar se $120 \mathrm{~km}$ por hora é o limite ideal a ser fixado ou questionar se a permissão para manejar um veículo a essa velocidade realmente salva vidas. Ele não pode decidir, seguindo convicções subjetivas, que seria preferível a fixação do limite máximo de velocidade em $80 \mathrm{~km}$ por hora, o que, sabidamente, poupa muitas vidas. Poderia estar provado nos autos, mediante laudos corretíssimos, baseados em estatística oficial, que o limite fixado em lei não é seguro, mas ainda assim não poderia substituir o critério do legislador pelo seu próprio entendimento.

104 BIX, Brian. Questões na interpretação jurídica. In: MARMOR, Andrei (Coord.). Direito e interpretação, p. 223. 
Entretanto, se alguns pressupostos fáticos revelarem-se inaplicáveis no momento do julgamento, poderá mandar reduzir o limite tratado para ajustar-se às condições que motivaram o legislador a optar pela escolha feita. É possível supor, por exemplo, que em face de uma grave crise econômica o Estado venha a abandonar a conservação das estradas, tornando-as perigosas e mal sinalizadas. Nesse caso, não mais subsistindo as condições de fato que levaram o legislador a permitir uma velocidade elevada em autoestradas, nenhuma invasão de competência praticaria o órgão julgador se determinasse a inaplicabilidade da norma, exatamente porque ela se encontraria em desalinho com a realidade. Não seria coerente nem razoável manietar-se o intérprete, sob a alegação de que não pode intrometer-se em assuntos típicos do Poder Legislativo. Na hipótese aventada, ele não estaria afastando-se da norma legal, e sim reconhecendo, com base científica indisputável, que não subsistem os pressupostos de fato existentes na ocasião da edição da lei.

Assim, o intérprete não pode apreciar pressupostos políticos ou de valor, mas pode conferir pressupostos factuais e jurídicos, ou seja, corrigir os pressupostos de fato ou de direito que se revelam falsos, mas não pressupostos de valor dos quais discorda. As adaptações são necessárias não para o intérprete impor o seu ponto de vista ou para melhorar o texto, mas para adequar aquilo que não pode mais ser aplicado em um mundo diferente. Elas são necessárias para preservar o todo e a intenção do legislador. Se a Justiça, nesse caso, determinar a volta aos padrões normais de velocidade, estará preservando a norma que havia fixado a velocidade de auto-estrada. A norma não tinha por objetivo estabelecer a velocidade de $120 \mathrm{~km}$ por hora, ao contrário, prescreveu uma velocidade compatível com a segurança dos motoristas em relação às condições da pista no momento em que foi editada. Reduzir o limite para uma velocidade compatível com as condições técnicas da estrada seria a única maneira de preservar a finalidade da norma que estabelecia o padrão anterior de velocidade. Por isso que o intérprete não poderia, a seu critério, eleger velocidades não previstas, como padrão, para outras condições de segurança. Nem considerar que os carros já saem de fábrica mais seguros e os motoristas estão mais comportados para aumentar o limite para 140 ou $150 \mathrm{~km}$ por hora, pois estaria corrigindo pressupostos de valor, não de fato.

Acontece o mesmo com os limites das competências atribuídas ao Tribunal de Contas e ao Judiciário. Justamente para preservar a unidade do sistema constitucional, as necessárias correções no sentido literal de suas normas, inclusive das que atribuem competência, devem ser entendidas em uma dimensão mais próxima da realidade e das 
necessidades próprias do presente, sempre tendo em vista o futuro e as transformações que as políticas públicas objetivam concretizar. Ao fazer essas correções - mutações, na verdade -, o intérprete muda o sentido do texto, sem alterá-lo, somente para preservar o seu sentido original.

Salienta-se, no entanto, em se falando de políticas públicas, que o Judiciário não poderia corrigir pressupostos políticos ou de valor. Por isso, não poderia considerar que a política desenvolvida pela ANAC em relação às condições operacionais dos equipamentos de radar e de controle de aproximação nos aeroportos poderia estar ligada ao perfil do quadro de servidores da INFRAERO e da agência reguladora sob o foco de uma inadequada remuneração e qualificação profissional de seus integrantes. Não poderia, da mesma forma, questionar os cortes nas propostas orçamentárias elaboradas pelo DECEA/COMAER, o contingenciamento de recursos e a fonte insuficiente de recursos para aplicação no controle do tráfego aéreo. Nem corrigir o pressuposto de valor adotado pelo Ministério de Minas e Energia para o enquadramento dos consumidores da subclasse baixa renda nos benefícios da tarifa social de energia.

O Tribunal de Contas, ao contrário, pode provocar a correção de rumo dessas políticas. Do prisma do controle de legitimidade dos atos do Estado e no exercício de sua função de auxiliar da sociedade, que podem ser vistos além de uma mera legalidade agravada, a Corte de Contas pode seguir adiante do último ponto no horizonte franqueado ao Judiciário. Algumas das questões postas no primeiro capítulo já podem ser respondidas e o que se percebe é que não se trata de competências rivais, mutuamente excludentes entre os Poderes, mas de competências que coexistem no aprimoramento da execução do interesse público. Estranho seria se não existissem limites para o Executivo.

Em se tratando da chamada reserva de jurisdição, não há afirmação mais vazia do que a recorrente alusão ao fato de que ao Judiciário sempre é dada a última palavra. Ele pode se manifestar por último em matérias de sua competência. Não fosse assim, seriam incompreensíveis as decisões definitivas emitidas por órgãos não-jurisdicionais, mas que também dizem o direito, como as provenientes dos juízos arbitrais, do CADE, da CVM, do CMN e do BACEN. Se essas decisões não forem ilegais, não podem ser reformadas pelo Judiciário. Reserva de jurisdição, a nosso ver, não significa mais do que exercício de competências exclusivas. O que desborda dessa competência, como o controle de políticas públicas sob o foco de pressupostos de valor, está fora do alcance daquilo que se pode entender como juízo de legalidade. 
Aqui reside, em suma, o verdadeiro divisor de águas entre a competência do Judiciário e a competência do Tribunal de Contas. Em se tratando de pressupostos de valor, o Judiciário é incompetente, por isso não diz a última palavra. O Tribunal de Contas, ao contrário, é competente, mas também não diz a última palavra, posto que a sua função é justamente a de fixar o problema, emitir um alerta e provocar a sociedade para o debate com os outros Poderes.

Percebe-se que os possíveis conflitos de competência só têm relevância dentro de um mesmo Poder. Entre entidades ou instituições autônomas e os três Poderes o conflito resolve-se de uma maneira muito mais complexa, no exame do caso concreto, tendo em vista a melhor efetivação do interesse público. Abandona-se, desse modo, a simplicidade do modelo anterior, que só preservava o exercício do poder, e adota-se uma fórmula aberta de resguardo do interesse público.

Em se tratando de competências, não se pode deixar de abordar um tema que é determinante para entender o Direito Público moderno: a relação entre legalidade e legitimidade.

\subsection{LEGALIDADE E LEGITIMIDADE}

A clássica apreciação da legitimidade plena em legitimidade originária, corrente e finalística e a excessiva abstração e generalidade do parágrafo único do art. $1^{\circ}$ da $\mathrm{CF}$ (“Todo o poder emana do povo, que o exerce por meio de representantes eleitos ou diretamente, nos termos desta Constituição") não dão o real alcance da noção de legitimidade finalística, ou teleológica. Confira-se, a respeito, o dispositivo equivalente na Carta espanhola: “Corresponde aos poderes públicos promover as condições para que a liberdade e a igualdade do indivíduo e dos grupos em que se integra sejam reais e efetivas, remover os obstáculos que impeçam ou dificultem sua plenitude e facilitar a participação de todos os cidadãos na vida política, econômica, cultural e social".

Se o nosso Diploma tivesse sido tão explícito, talvez não encerrasse tantas disposições programáticas, como a enigmática e vazia advertência de que o poder emana do povo, que o exercerá por meio de seus representantes, ou diretamente, nos termos desta Constituição. Que tributo presta à participação do povo e ao pluralismo a recomendação de que o poder pode ser exercido diretamente pelo povo? Frases de efeito, como a parte final do dispositivo comentado, comparadas à materialidade do mandamento do texto espanhol, 
fazem duvidar da corrente referência de ser a nossa Constituição uma das mais bem elaboradas do mundo.

A legitimidade finalística pode ser entendida como uma legitimação pelo resultado, ou seja, não basta a destinação correta dada aos valores públicos, nem a honesta e moral gestão fiscal, exige-se, como um plus, que as metas programadas sejam alcançadas. É critério tipicamente gerencial, de vez que o sucesso do empreendimento é exigido como condição de "legitimação" da legitimidade originária e coroamento final da legitimidade corrente.

A legitimidade originária é formal e de nenhum valor gerencial, mas a legitimidade finalística é creditada aos responsáveis pela competência do ato. A legitimidade ocorrente, por outro lado, deve ser atribuída também à pluralidade com que é exercido o controle pluralista da sociedade plural.

\subsection{COMPETÊNCIAS DEFINIDAS NA CONSTITUIÇÃO E TRIBUNAL DE CONTAS. COLISÃO DO PRINCÍPIO DA LEGALIDADE COM OUTROS PRINCÍPIOS}

Para bem compreender por que a legalidade não é tratada como princípio, como efetivamente é, e por que a solução dada à colisão entre princípio da legalidade e qualquer outro princípio não deve sempre privilegiar só a legalidade, convém examinar quais as diferenças existentes entre princípios e regras e como deve ser solucionado esse choque. Para isso, deve-se ter em mente que, em tema de relativização do princípio da legalidade, a colisão de princípios acontece principalmente entre os princípios da segurança jurídica e o da justiça, pois é evidente que a legalidade tem a função precípua de preservar a pirâmide do sistema normativo.

A principal diferença entre princípios e regras reside no fato de que princípios possuem dimensão de peso, podendo ser aplicados ao caso concreto parcial ou totalmente, dentro de um critério racional, ao contrário de regras jurídicas, que são aplicadas à maneira do tudo ou nada. Esse é o exato motivo pelo qual não há antinomia entre princípios. Dworkin define bem a questão ao informar que um princípio nada mais é que uma razão que aponta em uma determinada direção. Se competir com outro princípio que aponta em direção oposta, prevalece o que, no caso concreto, possui maior peso e relevância. Princípios jurídicos, por sua abstração e generalidade, não decidem casos concretos. Apontam regras jurídicas aplicáveis ao caso. Desse modo, o princípio da segurança jurídica 
e o da legalidade, evidentemente, só afastam o princípio da justiça e o do desenvolvimento da ordem social, com o devido respeito aos direitos fundamentais, na medida em que isso for indispensável para garantir a estabilidade, a paz e a tranqüilidade social.

Exemplo eloqüente é o modo de aquisição da propriedade por usucapião. O princípio que impede o efeito aquisitivo a quem pratica um esbulho - contrário ao direito , mas, mesmo assim pretenda dele tirar proveito, é suplantado por outro princípio, o da justiça e resguardo das situações consolidadas no tempo. Não há, na hipótese, exceção ao princípio de que ninguém pode tirar proveito de sua própria torpeza, apenas inexiste justificativa racional para atribuir maior relevância ao primeiro princípio. Por isso, não há antinomia entre princípios: podem ou não ser aplicados, total ou parcialmente, ao caso concreto, porque possuem peso e não são postulados. As regras, ao revés, são autoexcludentes. A aplicação de uma regra afasta todas as outras que poderiam, aparentemente, regular o caso. Princípios, ademais, são sensíveis ao contexto, ao passo que regras aplicamse somente à questão concreta que procuram regular.

Assim, a justiça, a moralidade e a dignidade do ser humano só podem ser restringidas, diante do princípio da legalidade estrita, na medida e na proporção necessárias para a preservação do sistema. O princípio é um padrão jurídico que justifica a aplicação de uma regra. A regra, portanto, não pode ser aplicada sem o esteio de um princípio que seja capaz de adaptá-la a um contexto de realidade.

Em conclusão, não pode a regra, por si só, objetivamente afastar princípios como os do desenvolvimento social, da justiça e da dignidade humana. Quando se diz que uma norma deve ser entendida dentro dos limites de seu enunciado, por mais alta que seja sua hierarquia, deve-se considerar, antes, que qualquer norma, mesmo constitucional, deve estar amarrada a um complexo sistema. Princípios, expressos e implícitos, e as normas que compõem o Direito Positivo são seu passaporte para adequação à unidade do conjunto. Sem essa circularidade entre a parte e o todo, a norma, em determinado contexto, resta isolada como uma estranha no ninho. Afinal, a lei, em sentido amplo, é a síntese do ser e do dever-ser, do virtual e do real, mas, sobretudo, a síntese do poder-ser. Se ela tiver de ser o que não pode ser, como a injusta e literal interpretação de uma norma de competência, será somente a síntese do absurdo.

Exatamente por ser um princípio, o princípio da legalidade deve ter o seu peso avaliado na aplicação do caso concreto, no contexto em que é invocado. É lógico que um princípio pode ser interpretado abstratamente, mas apenas para justificar a produção de regras de Direito Positivo e para servir de argamassa para a construção do sistema jurídico. 
O alcance de uma norma geral, entretanto, sem ligação com fatos concretos, não pode determinar, a priori, a prevalência sobre os outros valores envolvidos. Como bem lembra Fábio Konder Comparato,

\begin{abstract}
essa inteligência anterior ao exame de um fato concreto da vida social é, mais propriamente, um pré-entendimento (Vorverständnis), que está longe de esgotar o verdadeiro âmbito de incidência normativa. A verdadeira compreensão de um texto legal somente ocorre, quando ele é confrontado com os eventos da vida. É só então que ele adquire um colorido específico, próprio daquilo que os anglosaxônicos denominam law in action. ${ }^{105}$
\end{abstract}

Os princípios dirigem-se ao legislador, ao magistrado, às partes, aos órgãos da Administração e à sociedade, para que compreendam a estrutura orgânica e a exata dimensão do sistema de Direito. Princípios jurídicos, mesmo o da legalidade, não decidem casos concretos, indicam caminhos para a aplicação das regras de Direito Positivo que darão solução ao caso, de vez que, no plano abstrato, não há uma ordem preestabelecida de primazia de um princípio sobre o outro. Se colidirem com outros princípios, também aplicáveis ao caso, a proporcionalidade e a razoabilidade dirão qual o meio que melhor realiza ambos os princípios. Se a solução encontrada conduzir à não-realização do outro princípio, o peso do princípio escolhido para resolver a questão foi excessivo e desproporcional.

Por isso que Alexy chegou à conclusão de que a aplicação de um princípio deve ser sempre apreciada como uma cláusula de reserva, é dizer, o princípio é aplicado quando outro princípio não obtiver maior peso.

A segurança jurídica, resguardada pela legalidade, muitas vezes pode estar em colisão com o princípio da justiça, assim como o interesse público pode apresentar-se em conflito com o interesse particular, mas somente na presença do caso concreto pode o intérprete avaliar o peso que os princípios aplicáveis à espécie devem ter para uma otimização harmônica e proporcional.

Trata-se, em última instância, de saber reconhecer o demasiado e o muito pouco. A realidade do que realmente é e a falácia do que parecia ser. A concepção que é cega a um único princípio conduz a uma justiça formal, uma construção tão etérea e vazia como um imperativo categórico de Kant.

105 COMPARATO, Fábio Konder. Direito público: estudos e pareceres, p. 76. 
Como é fácil perceber, a nossa intenção, ao darmos ênfase à legalidade, tema de grande repercussão, é demonstrar como os princípios devem ser vistos pelo intérprete e como o sistema normativo conserva sua organicidade em face do novo constitucionalismo.

A legalidade é um princípio e, por isso, possui peso de aplicação se concorrer com outros princípios, não só pelo prisma material, como também no aspecto formal. Por esse foco, pode-se entender a extensão das competências atribuídas ao Tribunal de Contas. Se a legalidade é um princípio, o ajustamento de seu peso a determinadas situações concretas não representa, em verdade, agressão ao princípio. Isso não impede a reserva de lei, porque é um efeito desejado pelo constituinte, conforme consta no art. $5^{\circ}$ da Constituição Federal.

Alguns autores, como Maria Sylvia Zanella Di Pietro, afirmam que o Direito Administrativo está passando à frente do Direito Constitucional. Fazem crítica aberta à importação de modelo de Direito estrangeiro, baseado na common law, e à aplicação feita, segundo o seu entendimento, com evidente afronta à Constituição brasileira. Referindo-se às agências reguladoras, entende que

\begin{abstract}
vêm sendo criadas por meio de lei que lhes confere poder autônomo de baixar normas, quando se sabe que, pela Constituição, o poder regulamentar é privativo do chefe do Executivo e não há espaço no direito brasileiro para os chamados decretos ou regulamentos autônomos que existem em outros direitos, como é o caso do direito francês e do direito norte-americano. ${ }^{106}$
\end{abstract}

Tendo em vista que o art. $5^{\circ}$ da CF prescreve que "ninguém será obrigado a fazer ou deixar de fazer alguma coisa senão em virtude de lei”, conclui-se, apressadamente, que apenas a ela seria permitido introduzir qualquer inovação primária. Terá esse consagrado mandamento o sentido radical que lhe empresta a ilustre jurista? Cremos que não. Ainda há um fetiche, um respeito imoderado dedicado ao princípio da legalidade. Nesse sentido, a legalidade deixava de ser um princípio para se tornar um imperativo categórico. Como os princípios possuem a dimensão de peso, cuja aplicação não se resume no "tudo ou nada", a legalidade, tomada naquela acepção não-reflexiva, deixava de ser um princípio para se tornar uma regra. Por todas as razões mencionadas, pensamos que Maria Sylvia não tem razão.

Assim, o verdadeiro princípio da legalidade ficou de tal forma escondido que só era possível ver o imperativo que assumiu o seu lugar. Ele cedeu espaço ao seu entorno, que assumiu vida própria. Como ostentava a forma aparente da legalidade, enganava e convencia, assim como o mal, cuja força reside no fato de não ser explícito.

106 PIETRO, Maria Sylvia Zanella Di. Parcerias na administração pública. São Paulo: Atlas, 1999, p. 39. 
O Direito moderno, no entanto, principalmente a partir de 1990, começou a enxergar a matéria de fundo através da densa bruma formada pelo citado entorno, pois é imprescindível que se reconheça que o legislador não pode deixar de delegar ao Executivo aquilo que não pode fazer em tempo hábil.

É preciso entender que a concepção da legalidade, tal como visto há pouco anos, conduzia a um inevitável positivismo empírico, pelo menos quando se discute a forma de se captar a realidade. Recorda o Professor Eros Grau, verberando que o legislador não cria o direito, que ele apenas capta na realidade da vida aquilo que deve ser positivado, segundo sua própria sensibilidade. Não é bem assim. Em muitas matérias, como na área econômica, o condicionamento é recíproco, pois o Executivo regula a realidade da vida que o impulsiona a agir, mas age para obter efeitos e criar uma realidade que deseja alcançar, mas que não existe senão em nossas aspirações. Nesse sentido, o papel do legislador não é compreender o real, formar na mente cópia das coisas, como diria Ortega y Gasset, mas criar modelos segundo os quais estas hão de conduzir-se. Captar a realidade para legislar, mecanicamente, é formar idéias das coisas, o que não é suficiente. É preciso construir ideais aos quais essas idéias devem ajustar-se.

Há quem, diante da perplexidade desses argumentos, apresente solução mais drástica, como a substituição do princípio da legalidade pelo princípio da juridicidade. Guardadas as devidas proporções, é mais ou menos essa a nossa proposta. É no controle do Poder Público, efetuado da maneira mais plural possível, que o princípio da legalidade adquire densidade, posto que o preceito abstrato de legalidade não diz absolutamente nada. Este tem levado, freqüentemente, a decisões jurisdicionais tão desarrazoadas quanto a promessa de Clelia Conti a Nossa Senhora, na imagem descrita pelo escritor francês Stendhal, em seu livro A Cartuxa de Parma. Clelia havia prometido a Nossa Senhora que não mais veria o seu amante Fabrice, e, para não descumprir o prometido, passou a encontrar-se com ele na mais absoluta escuridão. Com efeito, a literalidade da norma evoca uma interpretação tão cega quanto o artifício encontrado pela personagem de Sthendal para não descumprir a promessa.

Por isso, Diogo de Figueiredo afirmou que há uma diferença entre compreender a ciência como uma representação objetiva do real e compreendê-la como uma maneira subjetiva de ver a realidade. Como Kierkegaard, percebe-se que o Direito como ciência não pode ser o simples reflexo do real, pois ele tem de ser uma representação de nós mesmos, da maneira como percebemos subjetivamente a realidade. Essa é a grande missão 
do Direito contemporâneo, não só do constitucional mas da teoria da norma, da teoria do direito.

O insigne mestre Diogo de Figueiredo lembra, a respeito, a polêmica que se instaurou em torno do novo projeto de lei de sociedades anônimas, que atribui às Bolsas de Valores autonomia normativa para decidir, no exercício de verdadeira parajuridicidade, problemas acontecidos na própria Bolsa de Valores, como nos países mais adiantados, sem intervenção da Justiça:

\footnotetext{
Os que estão olhando no espelho retrovisor vão dizer isso é inconstitucional. Está passando à Bolsa de Valores poderes do Estado, assim como está passando para as agências reguladoras poderes que eram do Presidente, e assim por diante. Isso é um palavrório inútil. Olhar o passado e ficar vociferando essas velhas lições serve para coisa nenhuma. $\mathrm{O}$ que temos que fazer é como disse Peter Häberle, outra vez me lembra o mestre, "buscar, interpretar nas Constituições a visão do futuro" $" 107$.
}

Se o legislador, muitas vezes, não é conduzido pela realidade, já que não aguarda estático o momento de agir, essa ação deve ser a mola que torna possível realizar o seu ideal. Essa celeridade, sem dúvida, não é compatível com a morosidade do processo legislativo ordinário. Nesse exato sentido, Luisa Torchia enfatiza que a

ciência do direito administrativo deve ser concebida como pesquisa das descontinuidades, da evolução, do progresso (...) o direito que buscava sua cientificidade na permanência dos fenômenos e na predefinição dos conflitos é substituído por um direito como saber problemático, em que a descoberta da melhor solução a priori é substituída pela pesquisa norteada pela lógica da compatibilidade e da adequação. ${ }^{108}$

\subsection{COMO SE DEVE ENTENDER O CONTROLE DA LEGITIMIDADE EXERCIDO PELO TRIBUNAL DE CONTAS. PLURALISMO E CONTROLE DO PODER PÚBLICO}

O Tribunal de Contas não aplica a lei, mas o Direito, e tem uma competência que nenhum outro poder possui, nem mesmo o Legislativo: o controle da legitimidade das contas públicas, no alcance máximo de sua tríplice dimensão.

A expressão sociedade pluralista, utilizada por Arthur Bentley, conduziu à nova concepção do poder pluralista, que é exercido, concomitantemente, pela sociedade,

107 MOREIRA NETO, Diogo de Figueiredo. A real interpretação da instituição Tribunal de Contas. Encontro nacional de conselheiros de Tribunais de Contas - Pré XXI Congresso dos Tribunais de Contas do Brasil. Palestra formulada no evento realizado no TCMRJ em 30 de março de 2001.

108 TORCHIA, Luiza. Apud MEDAUAR, Odete. O direito administrativo em evolução. 2. ed. São Paulo: RT, 2003, p. 274. 
composta dos mais diversos grupos sociais, e pelo Estado, gerido pelos representantes dos cidadãos, segundo normas preestabelecidas na Constituição. É de se ver que a chamada sociedade pluralista seria apenas um artifício de retórica se o poder também não fosse exercido por essa força plural. Esse pensamento tem estribo no próprio princípio federativo, porque "a federação não é um esquema jurídico que possa ser transformado em realidade tão-só pela enunciação no Texto Constitucional. A federação, como a democracia, é um processo que necessita constante aperfeiçoamento e adaptação a novas realidades". 109

Diogo de Figueiredo explica, com a lucidez que lhe é característica, que

\begin{abstract}
a principal distinção advinda do pluralismo social não se limita à coexistência harmônica de vários grupos no conjunto da sociedade, mas está, sobretudo, na peculiaridade de as pessoas poderem se alinhar simultaneamente a vários grupos, conforme os seus interesses prevalecentes, o que desenha um formidável caleidoscópio de situações sociais em permanente mudança, tornando impossível identificar um status exclusivo ou definitivo para quem quer que seja e, em conseqüência, classes estagnadas, que disputam entre si o Poder Estatal, como era comum no passado ${ }^{110}$ (grifos originais).
\end{abstract}

Nesse sentido, o princípio da isonomia, na formulação abstrata do Poder Estatal, só pode ser alcançado se o pluralismo social for capaz de fundar, concretamente, o poder pluralista. O pluralismo político, inscrito no art. $1^{\circ}$, inciso V, da Constituição da República, alcança o seu verdadeiro alcance e significado diante do pluralismo do poder. Veja-se bem, o pluralismo político tem seus alicerces no pluralismo do poder, que por sua vez decorre do pluralismo social, e não no pluralismo da simples representatividade. Essa, aliás, é a conclusão que se extrai do parágrafo único do art. $1^{\circ}$ da Constituição e que conduz à aceitação de que o pluralismo, tanto social como do poder, integram os direitos fundamentais do cidadão e de todos os grupos sociais, verdadeiros sujeitos do Direito Constitucional, e garantem o conceito de que o bem comum é o produto desse pluralismo. Evidente, então, que a representatividade exercida pelos eleitos da sociedade plural só encontra legitimidade enquanto expressar a cristalização desse pluralismo. Descarta-se, desse modo, o conceito objetivo de bem comum, ditado pelo Estado, ainda que sob o enganoso e largo manto da representatividade.

Como o pluralismo pode, efetivamente, controlar o poder estatal se a reprovação do mandante só for conhecida nos episódicos processos eleitorais? Mais, como pode o

109 BASTOS, Celso Ribeiro. Curso de direito constitucional. São Paulo: Saraiva, 1994, p. 249.

110 MOREIRA NETO, Diogo de Figueiredo. O novo tribunal de contas: órgão protetor dos direitos fundamentais, p. 39. 
cidadão comum (não o reduzidíssimo número de interessados) tomar conhecimento da gestão fiscal dos responsáveis pela Administração sem ser informado somente pela propaganda institucional dos entes federativos? Parece que, tecnicamente, só os Tribunais de Contas podem fazê-lo. O Parlamento, titular do controle externo da gestão fiscal, por sua própria constituição, arrimado nos pareceres dos Tribunais de Contas, denuncia as irregularidades com as cores vibrantes das posições políticas, o que faz esmaecer, a despeito da importância única de sua missão, a correção e o detalhamento técnico contidos na informação popular, características evidentes dos pronunciamentos insuspeitos do Tribunal de Contas.

Note-se que não se está diminuindo o alcance que a discussão da matéria em plenário produz. Apenas nos referimos ao fato de que essa informação, pela própria paixão dos argumentos esgrimidos por situação e oposição, só é completamente digerida e compreendida a partir das notícias que advêm do Tribunal de Contas e da mídia que cobre os casos mais rumorosos. Mesmo que se admita sejam esses casos um processo de fiscalização por amostragem, dão, inegavelmente, uma noção técnica e imparcial da gestão fiscal operada. Desse modo, se a atuação do Legislativo é imprescindível para a democracia e a liberdade, ela só se complementa e produz seus verdadeiros fins com a atuação verossímil das Casas de Contas.

\section{$\begin{array}{llllllll}\text { 6.5 O DIREITO } & \text { ADMINISTRATIVO } & \text { BRASILEIRO } & \mathrm{E} & \mathrm{O} & \text { DIREITO }\end{array}$ CONSTITUCIONAL. O CONTROLE SOCIAL DA GESTÃO PÚBLICA E O TRIBUNAL DE CONTAS}

O Direito Público é um reflexo do poder político. Embora as regras de Direito Público não mudem, necessariamente, para acompanhar a evolução do Estado moderno, são interpretadas e aplicadas segundo o estágio e o efetivo funcionamento do poder político. Desse modo, o Direito Administrativo não pode mais ser visto como simples ordenador dos atos e das relações do Estado com os particulares, nem como barreira levantada para estabelecer os limites de ação do Poder Público.

Conforme eloqüente imagem de Héctor Jorge Escola, ele deve ser a interface entre uma Constituição atuante e em contínua adaptação à realidade social com a política. Como bem divisou Humboldt, lembrado por Konrad Hesse, 
Toda Constituição, ainda que considerada como simples construção teórica, deve encontrar um germe material de sua força vital no tempo, nas circunstâncias, no caráter nacional, necessitando apenas de desenvolvimento. Afigura-se altamente precário pretender concebê-la com base, exclusivamente, nos princípios da razão e da experiência.

Prossegue o ilustre autor afirmando que,

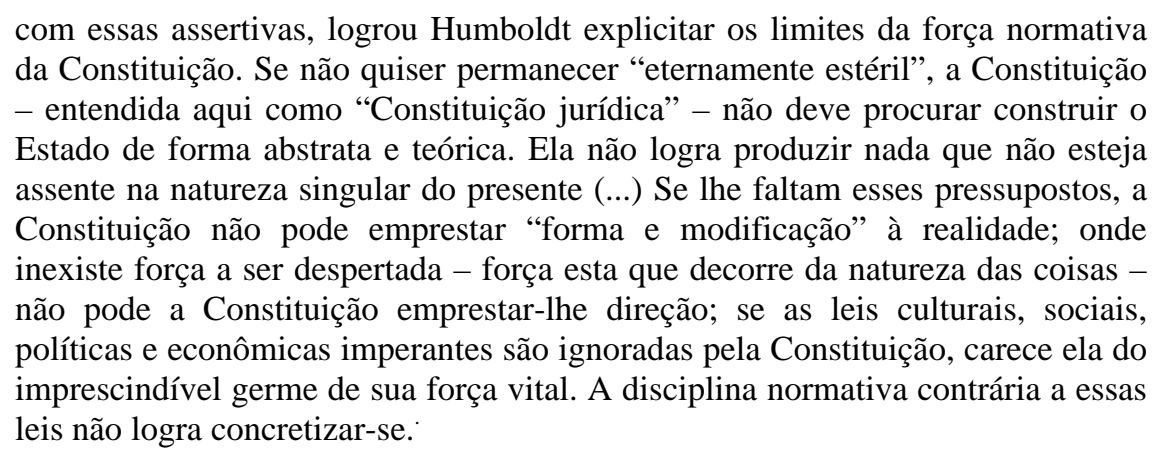

Mais à frente, esclarece que se definem,

ao mesmo tempo, a natureza peculiar e a possível amplitude da força vital e da eficácia da Constituição. A norma constitucional somente logra atuar se procura construir o futuro com base na singularidade do presente. Tal como exposto por Humboldt alhures, a norma constitucional mostra-se eficaz, adquire poder e prestígio se for determinada pelo princípio da necessidade.

Daí concluir que, em síntese, "pode-se afirmar: a Constituição jurídica está condicionada pela realidade histórica. Ela não pode ser separada da realidade concreta de seu tempo. A pretensão de eficácia da Constituição somente pode ser realizada se se levar em conta essa realidade". 111

Em outras palavras, a Constituição é condicionada pela realidade atual, ao mesmo tempo em que ordena, altera e molda essa mesma realidade. Eis a força vital da Constituição. Embora seja um Código abstrato, imóvel, permite que seu intérprete lhe dê vida e dinâmica ao seu conteúdo. Esse condicionamento recíproco entre lei e realidade, entre a Constituição e os fatos sociais e políticos, impede o isolamento da norma desvestida de elementos do presente e da realidade impotente para fazer valer o conteúdo normativo que possui.

111 HESSE, Konrad. A força normativa da constituição, p. 17, 18 e 23. 
A se aceitar que o Direito Administrativo é o Direito Processual do Direito Constitucional, como ensina Escola, se há o condicionamento recíproco da lei e dos fatos da vida real, deve evoluir juntamente com o Direito Constitucional. Naturalmente, não se espera que ele seja alterado toda vez que a Constituição sofrer alguma modificação importante, mas as suas estruturas e a forma como processa a interação do público com o privado precisam acompanhar essa evolução. A estrutura arcaica do mais importante ramo do Direito Público impede o desenvolvimento da força conformadora da Constituição. Devemos pensar o Direito Administrativo como um meio de comunicação com a sociedade, constituído de dois fluxos de ininterrupta influência. No sistema tradicional, há fluxo de dados de informação, mas não de influência Em uma visão moderna, o condicionamento de influências e interesses é recíproco, ao contrário da força conformadora da Constituição na visão estatizante, que é apenas retórica, como a utilizada na propaganda institucional e política.

Como o Direito Administrativo é o vínculo entre o Estado e a sociedade, a obsolescência de suas normas impede a interação concreta entre eles e reduz o exercício do Poder Público a mera legitimidade virtual. Se o Estado tenta fazer essa interação, mas continua a definir, por si próprio, qual deve ser o interesse público, fica difícil sustentar que esse sistema de Direito possa ser utilizado como instrumento apto à consecução do bem comum.

Desse modo, enquanto o Direito Administrativo garantir o bem comum, mas relegar ao Poder Público, com exclusividade, a definição de interesse público, nada terá mudado em relação ao século passado. A possibilidade de poucos idealistas poderem recorrer à Justiça como representantes da sociedade e de a consulta popular não passar de mera etapa formal a ser ultrapassada, demonstram que o poder da sociedade esgota-se na reparação dos desmandos, não na prevenção do dano. Essa deveria ser a finalidade do Direito Administrativo, tipicamente instrumental do Direito Constitucional.

Diante da inaptidão do estático Direito Administrativo para instrumentalizar a força normativa sempre dinâmica da Constituição - exatamente o que dá legitimidade à Administração para aplicar normas infraconstitucionais e eleger o que considera interesse geral -, aquela interface da Carta Suprema não encontra adequada previsão legal para regular a participação dos particulares na fiscalização da gestão pública.

Como o Poder Público, no dizer de Caio Tácito, "foi convocado a disciplinar e conter a atividade privada, sujeitando-a aos princípios do bem comum e da justiça 
social", ${ }^{112}$ e o bem comum só pode ser compreendido diante do caso concreto, pois não pode ser extraído de específicos dispositivos legais que regulam a matéria, é evidente que ele só pode ser aquilo que decorre do ordenamento jurídico como um todo, ou do que o órgão da Administração quer que seja. Tertium non datur.

O verdadeiro significado de interesse público não decorre de um misterioso poder discricionário conferido ao Estado, posto que aquele só pode ser encontrado nos diálogos mudos travados entre governantes e governados, feitos de, na sugestiva imagem de Érico Veríssimo, "imagens, ecos de vozes, alheias ou nossas, antigas ou recentes, relâmpagos súbitos que iluminam faces e fatos remotos ou próximos, nos corredores do passado - e às vezes, inexplicavelmente, do futuro". ${ }^{113}$ É dizer, ele é perpetuamente construído nas mais simples e corriqueiras relações que o Poder Público mantém com os administrados. É uma obra sempre inacabada que não pode ser aperfeiçoada em algumas consultas públicas, pois somente nas situações mais desimportantes, exatamente pelo seu grande número, é que a desigualdade a priori entre o Estado e o cidadão pode ser compreendida em seu verdadeiro sentido e alcance. Jacques Chevalier, a respeito, observa que

Sans doute, l'intérêt general n'est plus perçu comme opposé aux intérêts
particuliers, mais forme à partir d'eux et construit grace à la méditation des
groupes d'intérêts sociaux: mais cette évolution ne signifie pas qu'il ait perdu
toute consistance propre: le passage par la sphère publique introduit en effet
l'élément d'arbitrage et régulation indispensable, par lequel s'affirme la
spécificité du public. 114

Percebe-se que o Poder Público não é hermeneuta oficial do interesse público, nem pode este decorrer do texto legal, uma vez que o bem comum não pode ser concebido abstratamente, como se a sociedade fosse um todo homogêneo, de interesses comuns.

Os paradigmas do Direito Administrativo pátrio, entretanto, não se prestam ao Estado moderno, democrático e republicizado, nem conduzem a uma interatividade entre o Estado e a sociedade. Excluído, o cidadão não participa da gestão pública e também não a controla. A associação ou interação entre o setor público e o privado está a exigir uma atualização dos instrumentos legais de controle externo feito pelo Legislativo, pelo Tribunal de Contas e pelo chamado controle social. O controle social é indispensável, mas não pode ser exercido sem os meios necessários para permitir a efetiva participação da

112 TÁCITO, Caio. Evolução histórica do direito administrativo. In: Temas de direito público. Rio de Janeiro: Renovar, 1997, v. I, p. 3.

113 VERÍSSIMO, Érico. Solos de Clarineta. Editora Globo, v. 1, 1974, texto sem paginação que antecede o Capítulo 1.

114 CHEVALIER, Jacques. Public/prive. Paris: Presses Universitaires de France, 1995, p. 16. 
sociedade na gestão da coisa pública. Ademais, se nem o legislador nem o Executivo criam esses meios, cabe ao Tribunal de Contas vigiar o cumprimento da Lei de Responsabilidade Fiscal e dar publicidade às contas dos entes federativos. Como exemplo, dos 644 municípios que compõem o Estado de São Paulo (exceto o da capital), o Tribunal publica essas contas no Diário Oficial e as deixa à disposição de todos os cidadãos em seu site na internet, comparando-as com os dados do ano anterior, especifica a variação de Receitas e Despesas, o resultado da Execução Orçamentária e deixa claro quem administra bem ou mal.

Essa é uma maneira excelente, na falta de outros meios, de suplantar a antiquada tentativa de controlar os poderes públicos por meio do sistema de freios e contrapesos, decorrentes da "separação" dos poderes. Em verdade, como ensina Adilson Dallari, ${ }^{115}$ a Constituição não fala especificamente em separação de poderes, pois isso equivaleria "a triplicar a tirania", mas em poderes harmônicos e independentes que se submetem a limitações recíprocas.

Podendo ser provocado por qualquer cidadão, o Tribunal de Contas faz o que pode para interagir com a sociedade, como vimos, mas os sistemas de controle continuam, na prática, iguais aos de sempre, ou seja, quase sempre fundados no controle administrativo ou hierárquico. Enquanto não for dada ênfase para o controle democrático ou social e econômico, o controle continuará a ser exercido de maneira formal, com base em normas de Direito positivadas, regras de contabilidade pública e rigidez burocrática.

A questão não é fácil, pois a simples edição de dispositivos legais e estruturais pode resultar em um emaranhado cada vez mais volumoso de regras tão inúteis como aquelas que as precederam. Se a sociedade não perceber a efetividade de sua atuação no momento exato em que deve ocorrer, a mera representatividade de seus escolhidos nas Câmaras Legislativas continuará a operar inexpressivamente. O seu acompanhamento atuante, naquilo que se chama accountability vertical, é o que lhe permite retomar a soberania efetiva, que os constitucionalistas retoricamente lhe atribuem. Os momentos democráticos, que se renovam formalmente a cada legislatura, perdem toda a significância se não se expressarem no diário controle preventivo e concomitante com as sindicâncias dos atos da Administração. Os meios disponíveis de controle popular, como a ação popular, por exemplo, estão centrados no controle da legalidade do ato, pela própria limitação da

115 DALLARI, Adilson Abreu. Controle compartilhado da administração da justiça. Revista Eletrônica de Direito do Estado, Salvador, n. 2, abr./jun. 2005. Disponível em: <http://www.direitodoestado.com.br>. Acesso em: 25 dez. 2008. 
independência dos Poderes, e não são suficientes senão para tentar reparar o dano consumado. Como se vê, o controle social não se limita ao controle da legalidade, que, não obstante, ficaria muito mais fortalecido pela formação de uma consciência cívica.

O controle da gestão fiscal, em síntese, é mais social e de legitimidade que jurídico, de legalidade. Como o Tribunal de Contas julga tanto a legalidade como a legitimidade dos atos da Administração e o cidadão não tem garantida, senão retoricamente, a oportunidade de colaborar em consenso com o Estado, cabe aos Tribunais de Contas julgar as contas de todos os administradores de bens e valores públicos de uma maneira mais ampla, com uma nova leitura de suas atribuições. Por isso que dissemos ser a norma de competência também passível de interpretação.

Nesse foco, o Tribunal de Contas pode, muito mais que o Judiciário, aplicar princípios, diretrizes e regras de ciências não-jurídicas, como a economia e a administração gerencial. A propósito, Caio Mário da Silva Pereira, em discurso na Universidade de Coimbra, quando recebeu o título de doutor honoris causa, enfatizou que

\begin{abstract}
A todos vós posso afirmar com irrefutável segurança que o Direito deve buscar, também em outras ciências, sobretudo, sociais e humanas, apoio e parceria para afirmar seus princípios, reorganizando, metodologicamente, estudos e pesquisas. As relações humanas não podem ser tratadas pelo sistema jurídico como se elas fossem apenas determinadas pelo mundo da objetividade. Outras ciências indicam novos rumos ao Direito. ${ }^{116}$
\end{abstract}

Se esse caminho não é fácil de percorrer pelo Judiciário, apesar do desejável ativismo aguardado por todos, a Corte de Contas não precisa mais que assumir as largas possibilidades que lhe são destinadas pelas normas de competência, com uma leitura moderna e atualizada, além de dar publicidade aos atos de gestão fiscal e provocar o surgimento de novas formas de competências transversais e técnicas, mais que as implícitas, que só podem ser assumidas pelo órgão de contas.

Assim como a necessidade de pronta regulação fez o Executivo tomar uma importante fatia da competência exclusiva do Legislativo, como aconteceu na edição incessante de medidas provisórias, e na área econômica em geral, os Tribunais de Contas também têm condições de imprimir maior celeridade às suas decisões, em relação ao Poder Judiciário, que apenas é efetivo em sede de tutelas de urgência, as quais nem sempre resolvem a contento o problema.

116 Tribunal de Justiça do Estado de Rondônia. Disponível em: <http://www.tj.ro.gov.br/emeron/sapem/ 2004/ABRIL/0704/ARTIGOS/A10.htm>. Acesso em: 4 dez. 2008. 


\subsection{O TRIBUNAL DE CONTAS DA UNIÃO PERANTE O PODER JUDICIÁRIO, O PODER LEGISLATIVO E A TITULARIDADE DO CONTROLE EXTERNO. ELE É ÓRGÃO AUXILIAR DO PODER LEGISLATIVO? COMO SE DEVE ENTENDER A AUTONOMIA DO TCU}

Na estrutura da Constituição da República, as competências atribuídas ao Tribunal de Contas da União estão elencadas nos 11 incisos do art. 71, na Seção IX do Capítulo I, dedicado ao Poder Legislativo (Título IV - Da Organização dos Poderes). Nesta Seção, está previsto que a fiscalização contábil, financeira, orçamentária, operacional e patrimonial da União, das entidades da Administração Direta ou Indireta e qualquer outra pessoa física ou jurídica, pública ou privada, que utilize, arrecade, guarde, gerencie ou administre dinheiro, bens e valores públicos, será exercida pelo Congresso Nacional, mediante controle externo, com o auxílio do Tribunal de Contas da União. Isso, ademais, é o que lhe dá status de poder neutral, conforme será explicitado no item 7.6.

No art. 71 estão expressas as competências relacionadas em 11 incisos, que delimitam a atuação e os limites da ação do Tribunal de Contas da União, isto é, se compartilha essas competências com o Poder Legislativo, se apenas emite parecer, se fiscaliza, aprecia ou julga determinados atos e se tem autonomia suficiente para decidir e aplicar penalidades sem a concorrência do Congresso, por competência própria.

Trata, em suma, da maneira como o Congresso Nacional exerce a fiscalização externa das entidades que lidam com valores públicos e o compartilhamento dessa competência com o órgão especializado em contas públicas. Não se extrai daí nenhuma função jurisdicional anômala, ou sui generis, como querem alguns.

O que pode ou não ser reapreciado pelo Judiciário, se provocado pelo interessado, depende da verificação do que restou realmente decidido no Tribunal de Contas, tendo em vista que este órgão pode examinar não só a legalidade, mas a legitimidade dos atos da Administração, assumindo, de maneira isolada ou com o Poder Legislativo, funções de natureza política. Eficácia, moral administrativa, legitimidade do caráter financeiro de políticas públicas, controle fiscal da legitimidade e prudência dessas políticas, dão uma noção do amplo espectro da moderna visão das competências atribuídas ao novo Tribunal de Contas.

Como ficou claro, as competências fixadas no art. 71 da Constituição Federal não têm por objetivo reconhecer nenhuma jurisdição extraordinária, capaz de sobrepor as decisões do Tribunal de Contas às do Judiciário. As atribuições foram estabelecidas para disciplinar a maneira como são exercidas em relação ao Poder Legislativo. É que o 
Tribunal de Contas não é órgão auxiliar do Congresso Nacional, mas órgão autônomo especialmente incumbido de prestar auxílio ao Poder Legislativo, titular do poder de fiscalização contábil, financeira, orçamentária, operacional e patrimonial.

Com razão, o Ministro Carlos Britto, ao ressaltar o caráter constitucional do Tribunal de Contas, ensina que "as Casas de Constas se constituem em Tribunais de tomo político e administrativo, a um só tempo. Político, nos termos da Constituição. Administrativo, nos termos da lei"117.

Não se subordina o Tribunal de Contas ao Poder Legislativo, do qual guarda independência e autonomia. Tanto é assim que seus Ministros (Conselheiros nos estados e municípios) têm "as mesmas garantias, prerrogativas, impedimentos, vencimentos e vantagens dos Ministros do Superior Tribunal de Justiça...” ( $\$ 3^{\circ}$ do art. 73 da Constituição).

Tal dispositivo indica o caráter político que exerce o Tribunal de Contas, uma vez que é órgão autônomo na estrutura de poderes, cabendo-lhe exercitar suas competências próprias, mas em auxílio do Poder Legislativo. Nesse passo, o Legislativo é órgão de fiscalização (incisos IX e X do art. 49 da Constituição Federal) do Poder Executivo, cabendo-lhe a atividade de controle. Apenas em relação às contas é que cabe ao Tribunal "julgar" com autonomia. Essa circunstância lhe confere autonomia em relação ao Legislativo, uma vez que julga também as contas deste (inciso II do art. 71).

Ademais, o TCU não julga as contas do Presidente da República, apenas as aprecia, emitindo parecer (inciso I do art. 71), cabendo ao Legislativo tal julgamento. Em relação às demais contas, ao julgá-las, demonstra toda sua autonomia e independência.

Apesar da inserção do Tribunal de Contas no capítulo da Constituição Federal destinado ao Poder Legislativo, isso não indica, absolutamente, que esteja subordinado a esse Poder, nem que seus membros são dependentes dele ou a ele subordinados. Daí gozarem de autonomia política.

O verbo auxiliar não implica de maneira alguma subordinação. A Carta Federal não utiliza a expressão órgão auxiliar, apenas prescreve que o controle externo, a cargo do Congresso Nacional, será exercido com o auxílio do Tribunal de Contas da União. Em verdade, o Tribunal de Contas da União é órgão da União, autônomo, e não pertence a qualquer dos três Poderes. Presta auxílio ao Legislativo, que é o titular do controle externo das contas públicas, em razão de sua notória especialização, sem qualquer conotação de dependência.

117 BRITTO, Carlos Ayres. O regime constitucional do Tribunal de Contas. Revista de Diálogo Jurídico, Salvador, ano 1, n. 9, dez. 2001. 


\section{CONTROLE SOCIAL DE POLÍTICAS PÚBLICAS}

A primeira observação a ser feita sobre o controle de políticas públicas é a inutilidade do posicionamento que tem como fundamental a criação de um rígido esquema de repressão e combate às condutas menos éticas. Não descuidando desses recursos, o posicionamento ideal deve ser o de construção de um sistema incansavelmente criativo, que não pode ser inteiramente previsto com antecipação, já que inúmeras e imprevistas variáveis certamente ocorrerão durante o usualmente longo processo de implantação dos programas. Ante essa constatação, é intuitivo que as verbas orçamentárias de gestões diferentes, muitas vezes até de responsabilidade de gerações diferentes, tendem a sofrer realocações, supressões e acréscimos extremamente significativos. Crises econômicas, sociais e políticas de intensidades variadas interferem na continuidade dessas políticas e a própria participação da sociedade no espaço anteriormente ocupado exclusivamente pelo Estado já demonstra que as soluções ótimas para a condução de políticas administrativas continuadas só podem ser pensadas em termos de uma constante lapidação. Tudo isso sob as vistas daquele que não é mero figurante, mas protagonista e financiador de todos os projetos: o povo.

Insistimos na participação popular em larga escala porque a aproximação entre Estado e sociedade somente em razão da administração conjunta de serviços públicos proporciona o risco de captura de setores privados pelo governo, tornando-os nada mais que setores privados servis à influência político-econômica do Poder Público. É o que costuma acontecer com os grupos representativos de setores da sociedade que devem se manifestar nas formais audiências públicas oferecidas, por lei, à sociedade.

Cass Sunstein informa que a captura também é recorrente nos Estados Unidos com as agências reguladoras. A captura pode ser feita pelo próprio governo ou, pior, por setores economicamente poderosos das empresas alcançadas pelo interesse regulado. Esse tipo de corrupção, que muitas vezes consiste em informações milionárias de estratégias que estão para ser implantadas, é muito mais sutil e difícil de comprovar. Geralmente, as 
informações são dadas por boatos espalhados no mercado e em indícios. Não há provas cabais da corrupção, mas mesmo assim a prática precisa ser amplamente evitada. Por isso, raramente se fala em corrupção e em improbidade. Pelos valores envolvidos, opera-se em uma faixa moral que corresponde à máxima da mulher de César, pois, para quem exerce poder de regulação sobre o mercado, não basta ser honesto, é indispensável também parecer honesto.

Quem pode fiscalizar eficientemente o regulador e o controlador, aí incluindo até mesmo os magistrados e os juízes dos tribunais de contas, nesse nível sutil de responsabilização, no qual inexistem provas concretas, já que é de credibilidade que estamos falando?

A resposta é uma só: apenas um controle social pacientemente construído, à custa da eficiente provocação dos controladores, na forma preconizada nesta tese, com emprego da mais ampla visibilidade e publicidade dos planos e atos que compõem as políticas públicas, seria eficiente. Por outro lado, para que a sociedade se disponha a participar do controle, ao mesmo tempo em que o governo se disponha a acatá-lo, é de todo imprescindível que sua voz seja ouvida e levada em conta, de modo que ela possa reconhecer na vontade de seus mandatários a potencialidade de sua própria vontade. No item 8.1, em virtude da importância do tema, a questão será focalizada com maior atenção.

\subsection{CONTROLE SOCIAL, DEMOCRACIA E INFORMAÇÃO TÉCNICA}

Falar sobre controle social é o mesmo que falar de democracia e de Estado Democrático de Direito, por isso abordamos a questão longamente no segundo capítulo. Agora é o momento de tratar de um assunto que constitui o pressuposto da existência de

um Estado Democrático real, não de fachada: a informação. É a qualidade da informação, sem censura, sem maquiagem, que promove a crença de que o mandante pode influir no rumo dos planos, projetos e execução de programas públicos. Essa certeza de diálogo produtivo e influente dá credibilidade ao governo e à execução de planos que, muitas vezes, prolongam-se por mais de uma geração. O chamado governo dos mortos sobre os vivos, que continua impondo projetos cujas razões originárias talvez não permaneçam as mesmas, requer subsequientes reavaliações que só adquirem legitimidade se forem objeto de novas discussões, porquanto as previsões orçamentárias aprovadas no Legislativo já não guardam mais nenhuma relação com as novas alocações de verbas. 
Para que essas novas discussões sejam efetivadas, desta vez, como convém, diante do crivo da sociedade, é preciso que as matérias sejam apresentadas, na medida do possível, de maneira a serem amplamente compreendidas, especialmente para o perfeito entendimento da mídia, que deve ser a principal responsável pela divulgação dos planos do governo. Essa divulgação não seria feita, como costuma acontecer, como notícia de um fato consumado, mas de um projeto que pode ser lapidado com a ajuda de toda a sociedade, especialmente no que se refere à questão dos recursos que devem ser alocados ao programa. Embora a decisão final de atribuição de peso ao conjunto de prioridades que aguardam liberação de verbas pertença ao Executivo, a razoabilidade, proporcionalidade, economicidade, efetividade, eficiência e eficácia da opção devem ser previamente debatidas e sustentadas pelo Estado.

Para que esse grande fórum atinja as proporções esperadas, de modo a diminuir sensivelmente a sub-representação de setores menos influentes da sociedade, é preciso que a informação seja elaborada segundo padrões comprovados de técnica de avaliação. A questão, em tese, parece simples. Se a informação for suficiente e representativa dos problemas que envolvem a formulação e execução de políticas públicas, além de confiável, o amplo diálogo provocado acabará por conformar uma consciência social com densidade bastante para atrair a sociedade para o centro do debate.

No entanto, esse processo pressupõe que se saiba de antemão como produzir e oferecer informações. Quem tem isenção suficiente para processá-las? Que matérias devem ser processadas? Há critérios objetivos para pinçar, no oceano de fatos e necessidades públicas, as matérias que devem ser consideradas prioritárias para o debate, ou a própria sociedade também deve participar dessa escolha preliminar? Parece claro que há um risco potencialmente grande de valorar questões menos importantes, subestimar problemas de notável relevância, ou complicar de tal forma o processo que, dele, nenhum proveito resultaria, mas não há outro artifício para o ingresso da sociedade no jogo democrático, já que democracia só pode ser definida, como ensina Bobbio, como governo do Poder Público em público. $\mathrm{O}$ ensinamento reflete a essencialidade da publicidade em um viés eminentemente positivo, ou seja, de manifestação crítica na Administração Pública. Essa positividade refere-se aos meios obrigatoriamente criados pelo Estado para garantir o mais amplo direito de contestação oferecido à sociedade. Superando o paradigma weberiano, centrado no trinômio burocracia, eficiência e legitimidade, o valor participação suplanta o elemento burocracia e é recitado repetitivamente na Constituição de 1988, como uma forma de enfatizar a obrigatoriedade de sua concretização. 
$\mathrm{O}$ art. 29, inciso XII, por exemplo, expressamente determina a inafastabilidade da participação popular no planejamento municipal, assegurando às associações representativas o direito de cooperar ativamente com o Poder Público na administração dos municípios. No art. 187, a Constituição estabelece que a "política agrícola será planejada e executada na forma da lei, com a participação efetiva do setor de produção, envolvendo produtores e trabalhadores rurais, bem como dos setores de comercialização, de armazenamento e de transportes". O art. 194 prescreve que a "seguridade social compreende um conjunto integrado de ações de iniciativa dos Poderes Públicos e da sociedade, destinadas a assegurar os direitos relativos à saúde, à previdência e à assistência social”. Em seu parágrafo único, esse artigo determina que a organização da seguridade social obedecerá a um critério democrático e descentralizado da Administração, "mediante gestão quadripartite, com participação dos trabalhadores, dos empregadores, dos aposentados e do Governo nos órgãos colegiados". O art. 198 dispõe que "as ações e serviços públicos de saúde integram uma rede regionalizada e hierarquizada e constituem um sistema único, organizado de acordo com as seguintes diretrizes: (...) III - participação da comunidade".

O art. 204, II, tem a seguinte dicção: “As ações governamentais na área da assistência social serão realizadas com recursos do orçamento da seguridade social, previstos no art. 195, além de outras fontes, e organizadas com base nas seguintes diretrizes: (...) II - participação da população, por meio de organizações representativas, na formulação das políticas e no controle das ações em todos os níveis”. O art. 205 dispõe que "A educação, direito de todos e dever do Estado e da família, será promovida e incentivada com a colaboração da sociedade...", e o art. 206, VI, que o ensino será ministrado com base no princípio da "gestão democrática do ensino público...”. O art. 225 prescreve que "Todos têm direito ao meio ambiente ecologicamente equilibrado, bem de uso comum do povo e essencial à sadia qualidade de vida, impondo-se ao Poder Público e à coletividade o dever de defendê-lo e preservá-lo para as presentes e futuras gerações" (todos os grifos são nossos).

São tantas as referências à gestão com a comunidade que seria enfadonho prosseguir nessa senda interminável, mas uma última ênfase é dada ao $§ 3^{\circ}$ do art. 37 da Constituição Federal, porquanto a Emenda Constitucional n. 19/98, recepcionada como a emenda da reforma administrativa, instituiu uma norma geral sobre a participação popular na Administração Pública: 


\begin{abstract}
Art. 37. A administração pública direta e indireta de qualquer dos Poderes da União, dos Estados, do Distrito Federal e dos Municípios obedecerá aos princípios de legalidade, impessoalidade, moralidade, publicidade e eficiência e, também, ao seguinte: (...)

$\S 3^{\circ}$ A lei disciplinará as formas de participação do usuário na administração pública direta e indireta, regulando especialmente:

I - as reclamações relativas à prestação dos serviços públicos em geral, asseguradas a manutenção de serviços de atendimento ao usuário e a avaliação periódica, externa e interna, da qualidade dos serviços;

II - o acesso dos usuários a registros administrativos e a informações sobre atos de governo, observado o disposto no art. $5^{\circ}$, X e XXXIII;

III - a disciplina da representação contra o exercício negligente ou abusivo de cargo, emprego ou função na administração pública. (grifos nossos)
\end{abstract}

Já trouxemos a lição de Wolfgang Kersting de que "cidadãos não caem do céu", e de que "uma sociedade liberal não deveria relegar a formação de uma cidadania liberal ao acaso", e concluímos que uma democracia verdadeiramente deliberativa deve ser contínua e demoradamente construída. Agora, em sentido semelhante, afirmamos que um sistema eficiente e confiável de informações e avaliações de políticas públicas também demanda a mesma perseverança. É preciso desenvolver e manter uma cultura não somente de participação democrática na gestão pública, mas de exigência de uma contínua prestação de informações confiáveis capazes de tornar efetiva a co-gestão. É dever do Estado desenvolver e estabelecer mecanismos suficientes e aptos para concretizar o direito da sociedade de ser informada de seus planos, projetos e atos. Nesse sentido, é de rigor criar uma base de dados direcionada ao recolhimento e à síntese das questões administrativas mais representativas das necessidades socioeconômicas do povo, e um sistema para a disseminação mais abrangente possível dessas informações, bem como de avaliações e resultados relacionados com as políticas públicas.

Como o tradicional sistema de pesos e contrapesos não é mais suficiente para o controle externo do mérito de políticas de governo, em razão da captura de parte do Legislativo pelo Executivo e pelas empresas financiadoras de campanhas eleitorais, conclui-se que unicamente o controle social é capaz de acompanhar as ações governamentais em todas as suas fases, especialmente no momento em que estão sendo geradas, desde que sociedade esteja permanentemente abastecida das informações necessárias para consumar o controle. 


\subsection{ACCOUNTABILITY}

Embora o vocábulo accountability não possua um equivalente preciso em língua portuguesa, podemos conceituá-lo, no campo das ciências sociais, como responsabilização, ou seja, que remete para dimensões semelhantes a prestação de contas, responsabilidade social, verificação da qualidade de serviço prestado, responsabilidade eleitoral etc. Qualquer que seja o sentido com que o termo for empregado, no entanto, deve trazer ínsita a possibilidade de sanção. A prestação de contas, por exemplo, somente dará oportunidade à accountability se ela for feita com a finalidade de prevenir responsabilidades. Interessa-nos uma determinada espécie de responsabilidade: a política, cujas sanções não são jurídicas - nem por isso menos eficazes - e que muitos chamam de accountability vertical.

Assim, ainda que ilegalidades surjam na verificação da gestão, a accountability política, que se processa no meio social, e doravante nomeada simplesmente como accountability, pode não ocorrer, já que responsabilização política não é o mesmo que responsabilização legal ou jurídica. A sanção referida limita-se à reprovação política feita pelos cidadãos e consiste especificamente no desprestígio público que a conduta pública produziu. Pode-se até lembrar casos de políticos que, apesar de condenados e cassados pela Justiça, não tiveram seu prestígio abalado e foram reeleitos com a mesma popularidade que possuíam antes da condenação. Na accountability, em síntese, o julgamento de desempenho do governante ou do burocrata é feito exclusivamente pela sociedade ou por setores específicos de uma determinada comunidade (comunidade científica, mercado etc.). A nossa opinião, não obstante, não coincide com grande parte dos estudiosos, que pressentem na accountability qualquer sanção decorrente de formas legais e institucionalizadas. Sucede que conceito tão amplo retira do vocábulo a sua aptidão para designar uma específica responsabilização, ou seja, a sanção política indireta, própria da sociedade e não dos tribunais. Há outros conceitos legais muito mais precisos para designar a responsabilização jurídica do agente público. Por isso que não é costume falar de accountability de servidores públicos de carreira, porquanto não exercem cargos destinados a agentes políticos. Não nos interessa, portanto, a chamada accountability horizontal - já que controle externo e interno são expressões de uma nomenclatura muito mais apropriada para esse tipo de responsabilização - nem a aprovação da gestão administrativa. 
Nesse sentido restrito, accountability é termo que designa o juízo de desaprovação que os eleitores fazem dos resultados consumados ou aguardados de políticas que foram, estão sendo, ou serão implantadas por um governo democraticamente eleito. Por isso, a responsabilidade que queremos destacar é mais ampla, da accountability eleitoral, que acontece nos momentos eleitorais em que o cidadão se manifesta formalmente e que pode não refletir mais os sentimentos havidos no momento em que os atos receberam desaprovação popular.

Esse é exatamente o elo, o ponto de ligação que queríamos estabelecer entre accountability e controle social efetivo. Sem informação e sem a atuação que propusemos neste trabalho para o Judiciário e o Tribunal de Contas, os fatos já caíram no esquecimento ou se perderam na sucessão de crises políticas das mais diferentes responsabilidades. $\mathrm{O}$ mal consumado, de igual maneira, é motivo relevantíssimo para a perda do interesse social pela punição, assim como a ineficiência dos meios institucionalizados no controle e na punição dos culpados conduz à mesma apatia do cidadão. Exemplo gritante dessa ineficiência, não importa se imputável à Justiça ou ao sistema, é o caso dos 25 automóveis doados pelo Prefeito de São Paulo aos jogadores da seleção brasileira de futebol campeã do mundo em 1970. O caso demorou 32 - trinta e dois - anos para transitar em julgado e foi decidido com um fundamento unicamente formal: a Constituição de 1969 não previa recurso extraordinário quando uma lei federal era violada por uma lei local. Eis a notícia veiculada no CONJUR:

Por maioria, o STF entendeu que a ação de Maluf era procedente. O argumento
vencedor baseou-se na Constituição de 1969 , que não previa o Recurso
Extraordinário quando uma lei federal era violada por meio de uma lei local. A
Corte entendeu que a decisão anterior foi baseada apenas em análise de normas
locais e, por isso, merecia ser revogada.
Posteriormente, o autor da Ação Popular recorreu por meio de embargos
infringentes, que foram a julgamento em 2002 . O relator da questão na ocasião,
ministro Néri da Silveira, votou pela manutenção da condenação de Maluf a
ressarcir os cofres públicos e foi acompanhado pela ministra Ellen Gracie. No
entanto, a maioria manteve o julgamento anterior da Ação Rescisória, que
beneficiou o ex-prefeito.

Abstraindo qualquer aspecto político da decisão, releva-se apenas o tempo que o sistema judicial levou para produzir algo semelhante ao parto da montanha que deu à luz um rato. Se houvesse um sistema eficiente de informações, não do fato em si, mas das consequiências sociais que a liberalidade produziu e dos argumentos utilizados pela defesa

118 Revista Consultor Jurídico, 18/04/2006. Disponível em: 〈http://www.conjur.com.br/static/text/43642,1〉. Acesso em: 4 dez. 2008. 
e pela acusação, um importante passo seria dado na direção da formação de uma consciência cívica. É evidente que as mazelas de nosso sistema processual-judiciário não estariam solucionadas em um piscar de olhos, mas, com toda certeza, já estaríamos, hoje, passados 38 anos, em um estágio de accountability e de controle social muito mais efetivo.

Um problema que só pode ser solucionado com informação precisa, educação cívica, e consciência social é o do alvo da accountability. Explica-se: muitas vezes, é difícil distinguir a quem se deve imputar a responsabilidade maior pelo plano impugnado pela maioria dos cidadãos. Com a autonomia das agências reguladoras, até onde é possível responsabilizar o Presidente da República por atos impopulares editados pelas agências? É possível que o eleitorado continue entendendo que a responsabilidade do chefe do Executivo nunca desaparece com atos de seus "subordinados". Embora não haja nenhuma subordinação em relação às agências independentes - já que são independentes -, torna-se dificultoso compreender como uma autarquia especial pode ignorar a vontade política de quem foi eleito justamente para concretizar sua plataforma eleitoral e promover mudanças econômico-sociais. Independência, por esse foco, é sinônimo de compartilhamento de poder?

Durante o Governo Lula, as escaramuças entre a Agência Nacional de Energia Elétrica (ANEEL) e a Agência Nacional de Telecomunicações (ANATEL) puseram a nu a o receio de que o Presidente sofresse as conseqüências eleitorais de atos impopulares das agências, dos quais divergia frontalmente. O Presidente reagiu publicamente à accountability que suportava e optou pela alternativa de negar a responsabilidade e demonstrar a sua inoperância em relação à independência das agências. Como a estratégia deu resultado, resta absolutamente clara a importância da informação no exato instante em que as medidas administrativas são tomadas. Como é evidente, seria de nenhuma utilidade para o chefe do Executivo a resposta final de accountability eleitoral.

O exemplo do Presidente Lula, por mais relevante que seja, não responde a todas as questões, pois ele ocupava uma posição de empatia com a sociedade que lhe permitia o mais pleno acesso aos meios de comunicação. Outros agentes não tão poderosos talvez não pudessem se desvencilhar da imputação de responsabilidade por atos de agentes independentes.

De qualquer forma, e é isso que se quer deixar assente, o debate nacional que ocorreu a partir dos ataques do Presidente e da resistência dos dirigentes das agências foi determinante para a manutenção da independência dessas autarquias especiais com temperamentos. Hoje, formou-se uma cultura sobre esse assunto, que, não obstante a sua 
complexidade, acabou freqüentando as conversas informais dos cidadãos, como matéria de interesse geral. O fato, mais que qualquer outra conclusão, demonstra ser possível captar o interesse público para concretizar o controle social da forma como indicado neste trabalho. Dessa discussão, que infelizmente não teve seqüência, alguns pontos positivos foram publicamente debatidos, como o artifício governamental de engessar as agências reguladoras rebeldes com a não-nomeação de seus diretores. Expedientes como esses, embora graves, ficavam sem qualquer controle e correção.

Por outro lado, demonstrando que o controle proposto depende mais de informações precisas que de consciência social, invocamos o exemplo dos Estados Unidos e a desastrosa guerra do Iraque. Uma das mais evoluídas formas de democracia foi à guerra e manteve uma sangrenta, desgastante e inglória batalha em razão de uma mentira: a falsa e fantasiosa informação de que o Iraque possuía armas de alto poder de destruição da vida humana. O fornecimento de informações mentirosas e a psicologia da catástrofe iminente foram capazes, também, de manter uma legislação tão abjeta quanto as regras de exceção impostas após o 11 de setembro, até o fim do mandato do presidente Bush. Mais de meio milhão de vidas humanas foram exterminadas em razão de um engano, reconhecido publicamente até pelo presidente Bush em novembro de 2008.

Quem pensou que a propaganda mal dirigida e assimilada sem maiores indagações críticas estava presa à memória de um passado que se acreditava morto enganou-se. Mais que nunca, principalmente em face do crítico momento econômico por que passamos, é preciso começar a conformar uma consciência responsável de solidariedade e participação. Mais uma vez, reafirmamos que controle do poder, e do poder que controla o poder, não pode ser feito sem a cooptação da sociedade.

\subsection{CONTROLE SOCIAL DE POLÍTICAS PÚBLICAS E JUDICIÁRIO}

Não há, de fato, como controlar o poder, nem o poder que controla o poder, sem uma efetiva e constante relação de legitimação social dos atos públicos emanados dos poderes institucionalizados. Direito, política, poder normativo, governo, administração e direitos humanos não sobrevivem nem recebem o sopro vital da legitimação sem a fertilização diária do consentimento popular.

Direito codificado e dogmática jurídica não servem para mudanças significativas, são úteis apenas para lentas mutações de uma ordem dada, incapaz de admitir alterações 
bruscas em idéias sedimentadas secularmente sem um forte sentimento de insegurança diante de tudo que é novo. Reconheça-se, aliás, que o Judiciário resiste em assumir uma posição que se aproxime, ainda que ligeiramente, do legislador positivo. Isso é bom, porque seria extremamente perigoso permitir que o magistrado pudesse operar na nebulosa divisa da política com o Direito, mas não pode levar a instituição a um fundamentalismo inconseqüente que dogmatiza a lei e a Constituição. A questão encontra-se em debate nos Tribunais Superiores, mas se encaminha para soluções que dificilmente conciliam devido processo legal e segurança jurídica. Em entrevista ao Jornal do Brasil, o Ministro Luiz Fux, quando ocupava a presidência da $1^{\text {a }}$ Seção do Superior Tribunal de Justiça, defendeu o ponto de vista de que a "prodigalidade recursal desprestigia a Justiça de primeira instância" e impõe "uma ditadura ideológica dos tribunais". A sua posição, adotada por muitos, enfatiza a necessidade de "romper-se o mito da neutralidade do juiz, tornando-o mais ativo, em prol da igualdade das partes". 119

O Ministro Gilmar Mendes, ${ }^{120}$ no mesmo sentido, queixa-se do "quase hábito nacional de exigir a intermediação judicial para fazer-se cumprir a lei”, e recomenda "alternativas vantajosas" para "debelar a cultura 'judicialista' que se estabeleceu fortemente no País, segundo a qual todas as questões precisam passar pelo crivo judicial”.

Ambos têm razão - em termos. Certamente, parece ser menos interessante deixar o Judiciário dizer, tardiamente, a última palavra em quase tudo do que dizer alguma coisa em tempo razoável, mesmo compartilhando competências com outros atores capazes de efetuar o controle social de políticas públicas. A esse respeito, é de se reconhecer que as decisões do Supremo Tribunal Federal possuem nível elevadíssimo, mas a instituição, por mais respeitada que seja, nunca sairá de seu isolamento nem estimulará “a crença no valor inquestionável da cidadania”, como diz Gilmar Mendes, se a sua resposta não acontecer em tempo real, na flagrância dos fatos e das comoções públicas.

Para fugir de uma concepção extremada de segurança jurídica, que só admite o Judiciário como poder neutro e imparcial, o Supremo Tribunal Federal assumiu, em 2007, uma posição considerada determinante para o reconhecimento de uma nova era no Judiciário. Estamos nos referindo, entre outros casos, à mudança de interpretação dada ao mandado de injunção. Esse Tribunal sempre entendeu que o direito de greve dos servidores públicos deveria pautar-se pelos ditames de uma lei específica que nunca foi editada. Sua

119 JB On Line. Luiz Fux: mito do juiz neutro tem de ser rompido. Disponível em: <http://noticias.terra.com.br/brasil/interna/0,,OI2892844-EI306,00.html>. Acesso em: 17 maio 2008.

120 MENDES, Gilmar. Palestra proferida aos estudantes de Direito da Universidade Humboldt, de Berlim. Disponível em: 〈http://www.conjur.com.br/static/text/71867,1〉. Acesso em: 19 nov. 2008. 
atuação, portanto, não comportava mais que a fixação da mora legislativa. Qualquer invocação no sentido de suprir a inconstitucional omissão do Legislativo esbarrava na efetiva ausência do dispositivo legal reclamado pelo art. 37, VII, da Constituição Federal, e tornava a ordem constitucional para a edição da lei uma promessa completamente vazia. Conhecer do mandado de injunção apenas para cientificar o órgão legislativo sobre a ausência da lei regulamentadora era decisão que fazia a Corte Constitucional assumir uma posição complacente que não condizia com as suas elevadas atribuições de guardiã da norma constitucional.

Para não ser acusado de assumir a posição de legislador positivo, o Supremo Tribunal Federal violou uma clara determinação constitucional feita 19 anos antes do julgamento do MI n. 712-8. A recusa em fazer algo tão simples como aplicar, por analogia, a lei de greve vigente no setor privado (Lei n. 7.783/89) aos servidores públicos naturalmente, com os temperamentos necessários para garantir o funcionamento de serviços essenciais - só pode ser compreendida em face de um cego fetiche de dogmas que há muito perderam a racionalidade. O Ministro Celso de Mello, em decisão inspirada, alertou que a prolongada omissão do Congresso Nacional efetivava uma degradação contínua da Constituição, sujeitando-a à vontade ordinária do legislador comum:

\begin{abstract}
O comportamento negativo dos poderes constituídos - que deixam de editar normas regulamentadoras do texto constitucional, previstas, em cláusula mandatória, na própria Constituição - torna inviável, numa típica e perversa relação de causa e efeito, o exercício de direitos, liberdades e prerrogativas assegurados, às pessoas, pelo estatuto fundamental. O desprestígio da Constituição - por inércia de órgãos meramente constituídos - representa um dos mais graves aspectos da patologia constitucional, pois reflete inaceitável desprezo, por parte das instituições governamentais, da autoridade suprema da Lei Fundamental do Estado ${ }^{121}$. (grifos no original)
\end{abstract}

Tão significativa quanto a decisão referida foi a realização, em 20 de abril de 2007, da primeira audiência pública da história do Supremo Tribunal Federal. Nessa ocasião, a Corte procurou subsídios junto à comunidade para poder decidir sobre a polêmica questão das células-tronco embrionárias. O mesmo recurso analógico registrado na decisão do mandado de injunção foi empregado para suprir a falta de previsão institucional para a audiência pública. Utilizaram-se, para o caso, os parâmetros prescritos no Regimento Interno da Câmara dos Deputados.

121 Supremo Tribunal Federal, Mandado de Injunção 708-0 Distrito Federal, voto do Min. Celso de Mello no julgamento do direito de greve dos servidores públicos. 
Essa solução é revolucionária porque presta homenagem à questão material de integrar a sociedade na discussão e resolução de temas de interesse social relevante. Como é indiscutível, a Corte não necessitava promover audiência públicas, da maneira como fez, para se julgar apta a decidir sobre o significado da vida e do respeito à esperança de vida dos embriões. Assim o fazendo, impediu que o Estado fosse visto como a antítese da sociedade. A qualificação excepcional de seus membros não impediu que a Corte se aproximasse da opinião pública, de seus anseios e reclamos. Em uma decisão oposta ao ensinamento de Platão, humildemente deixou de considerar a si própria uma notável reunião de especialistas e aproximou-se da sociedade de maneira impressionante.

Nessa nova trilha, o Supremo Tribunal Federal mostrou novamente a sua firme determinação de integrar a sociedade na condução das questões constitucionais quando decidiu, na sessão administrativa de 27/11/2008, que os julgamentos sobre existência de repercussão geral serão, a partir de agora, abertos ao público.

\footnotetext{
Os votos da Corte sobre a admissibilidade dos processos que chegam ao Tribunal, vindos de instâncias inferiores, são computados por um sistema chamado Plenário Virtual. Esse sistema exigia uma senha de acesso restrita aos ministros do STF e aos tribunais cadastrados, mas, já nos próximos dias, estará desbloqueado e disponível para consultas na internet pelo site do Supremo (www.stf.jus.br).

O usuário do site poderá acompanhar, em tempo real, o voto de cada ministro no julgamento sobre a existência de repercussão geral. ${ }^{122}$
}

Todas essas decisões representam uma verdadeira viragem em relação à dicotomia Estado-sociedade. Pode-se aspirar, desde então, a uma renovada assunção de competências que sempre pertenceram ao Poder Judiciário. O fato de ser revolucionária não significa que uma nova atribuição tenha sido concedida ao magistrado, ao contrário, o que inexistia era uma condição política favorável para o Judiciário assumir uma atribuição que só ficou suficientemente clara com a evolução do Estado Democrático de Direito.

O mesmo acontece com a posição defendida nesta tese. O controle social de políticas públicas efetivado com auxílio e provocação do Poder Judiciário e do Tribunal de Contas não necessita nada além de uma imediata assunção de competências que sempre lhes pertenceram. Agora já é possível entender o porquê da alusão feita no item 6.1 ao Hamlet, de Shakespeare. Ali afirmamos que a obra do genial autor encerra aspectos ainda desconhecidos, que só serão descobertos no futuro, como ocorreu após a primeira

122 STF, 27/11/2008. Disponível em: <http://www.stf.jus.br/portal/cms/verNoticiaDetalhe.asp?idConteudo=99846> . Acesso em: 29 nov. 2008 . 
interpretação psicanalítica de sua obra. A obra em si - assim como as regras que determinam as competências dessas duas instituições - não mudou. Os diálogos não escritos entre a Constituição e a sociedade é que adquirem valor e compõem um todo nunca completo, tornando inesgotável o círculo hermenêutico com o Direito. O que não era tido como importante na interpretação constitucional passou a ser fundamental para o seu entendimento.

Exatamente por isso enfatizamos que, assim como no Hamlet, o que não era conhecido ou não era considerado importante em 1988 passou a ser, igualmente, fundamental para o significado do sistema constitucional, da mesma forma como o que é relevante hoje poderá sofrer novas e profundas modificações no futuro. Isso, aliás, é o que mantém a perene autoridade da Constituição norte-americana desde 1787.

É claro que decisões esparsas anteriores a 2007, marco temporal de uma nova era no Judiciário, já reconheciam a possibilidade de se aferir a justiciabilidade de políticas públicas, mas a maioria esmagadora dos julgados considerava que não cabia a juízes e tribunais

... assomar para si a deliberação de prática de atos de administração, que resultam sempre e necessariamente de exame de conveniência e oportunidade daqueles escolhidos pelo meio constitucional próprio para exercê-los.

Salta à evidência que, por sérias e bem intencionadas que sejam as posições de não administradores (...) de ver dotada a pequena Oriente de melhores condições de saneamento básico, tal circunstância nem de longe arreda a objeção de que, dentro de seus critérios próprios, podia e devia a Administração Municipal dosar prevalências, usando seus recursos financeiros, em assim entendendo, para outros campos, sabido que são várias as urgências a que devem atender as Prefeituras.

Logo, a presente ação civil pública o que fez foi discriminar entre as urgências da comunidade, escolhendo uma como maior que outras tantas, e ordenando que fosse atendida, o que não tem cabida ao prisma da ordem político-social, como também ante a Constituição Federal, desde o seu artigo $2^{\circ}$, nem é da letra ou sentido da legislação específica das ações civis públicas. ${ }^{123}$

Outro julgado, no mesmo sentido, que realmente impressionava pela fundamentação, sustentava que

O provimento desborda flagrantemente dos lindes jurisdicionais, implicando grave usurpação da atividade discricionária, que ao Poder Público in genere é atribuída, consistindo, mesmo, em uma de suas mais relevantes motivações funcionais. (...) Permitir, por hipótese, que o Judiciário, extravasando as comportas de sua atuação hétero-compositiva, venha a coatar o Executivo a uma obra, embora a repute conveniente e inadiável, traduz frontal lesão ao princípio

123 TJSP, $5^{\text {a }}$ Câmara Cível, j. 07/05/1992, rel. Des. Marco César. 
constitucional que considera os Poderes harmônicos porém independentes entre si.

(...)

Se, per absurdum, convalidássemos a insólita fiscalização dos atos da Administração Pública pelo Judiciário, sem ressaibo de dúvida teríamos implantado o caos. Este último assumiria um desconcertante monismo funcional, como instância não de reparação das mazelas administrativas, mas órgão reitor de toda a dinâmica executiva. ${ }^{124}$

Maria Paula Dallari Bucci, em obra clássica ${ }^{125}$ sobre políticas públicas, apresenta outro julgado do mesmo Tribunal paulista, sobre o mesmo tema, em sentido oposto aos anteriormente transcritos:

Todas as partes convêm em que é imperiosa e inadiável a construção de sistemas de tratamento de esgotos. A saúde coletiva é, por sua natureza, prioritária e, a respeito, não há discricionariedade do Poder Público: sem água cujos padrões de pureza se encontrem dentro das classes legais de aproveitamento (cf. Anexo ao Decreto Estadual n. 8.468, de 8.12.1976), a própria vida não é possível, como bem primeiro!

Nem devem arrecear-se de que se lhes imponha ônus financeiro incompatível com sua força orçamentária. Não foi por outra razão, senão para adequar os projetos e cronogramas às disponibilidades financeiras dos orçamentos das devedoras que, com sensatez, a r. sentença submeteu a arbitramento prévio, à luz da prova técnica ampla, o prazo de cumprimento da obrigação declarada. ${ }^{126}$

A evolução da participação do Poder Judiciário no Estado Democrático de Direito atual, reconhecida pelo Supremo Tribunal Federal desde 2007, acompanha uma tendência que pouco a pouco assume posição de destaque na garantia dos direitos fundamentais e sociais em uma democracia verdadeiramente deliberativa. Enquanto não considerarmos essa participação do magistrado como necessária, o controle de políticas públicas continuará a oscilar entre as fórmulas relatadas nos julgados do Tribunal de Justiça de São Paulo supratranscritos.

Como sabemos que a avaliação de políticas públicas e os programas que delas resultam, uma vez que esses são a concretização daquelas, dependem de uma macroperspectiva do contexto em que estão inseridos, a visão míope que o Judiciário tem demonstrado em relação à questão da judicialização das políticas só deixará de existir no instante em que assumir uma postura totalmente diversa no controle de mérito dos atos administrativos. Constitui erro grosseiro continuar a dirigir o foco de avaliação diretamente para cortes destacados do conjunto de políticas e prognósticos que são feitos da economia.

124 TJSP, $4^{\text {a }}$ Câmara Cível, j. 29/10/1992, rel. Des. Vianna Cotrim, voto do Des. Ney Almada.

125 BUCCI, Maria Paula Dallari. Direito administrativo e políticas públicas. São Paulo: Saraiva, 2002, p. 275.

126 TJSP, $2^{a}$ Câmara Cível, j. 26/05/1992, rel. Des. Cezar Peluso. 
Não é esse o nosso entendimento. Acreditamos que algo muito produtivo pode ser realizado a esse respeito. É o que faremos, a seguir, com a apresentação de novos paradigmas internacionais para a atuação do magistrado.

\subsection{JUdicialização DE POLíticas PÚblicas E OS NOVOS PARADIGMAS INTERNACIONAIS}

Trazemos ao debate as experiências concretizadas com sucesso na África do Sul, Índia e Colômbia. A falta de tradição cultural jurídica desses três Estados não deve levar à falsa consideração de que eles nada poderiam ensinar aos operadores tradicionais do Direito. Principalmente depois de 11 de setembro de 2001, a afirmativa encontra razoável suporte. É evidente que excessos foram cometidos, especialmente na Índia, em relação ao poder de ingerência do Judiciário na condução de políticas públicas, porém, com a devida cautela, a lição pode ser proveitosa para a tese de controle social ora sustentada.

$\mathrm{Na}$ Índia, à semelhança da desburocratização operada no Supremo Tribunal Federal, no sentido de disponibilizar, em tempo real, aos internautas os votos dos Ministros sobre a admissibilidade de existência de repercussão geral, uma notável medida concretizou o sonho de aproximar a sociedade em geral da ação "ativista" de sua Corte.

Roberto Gargarella, professor de Direito Constitucional na Universidade de Buenos Aires, informa que o antiformalismo da Corte indiana concedeu aos pobres e ignorantes o direito à chamada "jurisdição epistolar", por meio da qual qualquer pessoa, qualquer ser humano, por mais miserável que seja, está legitimado para dirigir-se à Suprema Corte mediante uma simples carta rabiscada (não uma petição formal), em favor de um grupo marginalizado. Enquanto no Brasil, país com população equivalente a um sexto da população da Índia, dificultamos, cada vez mais, a forma de se chegar aos Tribunais Superiores, a experiência levada a efeito em um Estado que em 2035 terá o maior número de habitantes entre todos mostra-se bastante interessante. Como se percebe, a questão fundamental da diferença de acesso entre os dois países reside na forma como o peticionário estaria legitimado para invocar a proteção da Corte Superior. No Brasil, o STF encontra-se abarrotado com questões que não ultrapassam os interesses das partes, na maioria das vezes, repetitivos. Na Índia, ao revés, "los portales de la Corte se abren a los 
pobres, a los ignorantes y a los analfabetos, y sus casos han comenzado a llegar a la Corte por medio del litigio de interés público", segundo informa o Juiz Bhagwati. ${ }^{127}$

Para tornar mais efetiva essa orientação transcrita,

\begin{abstract}
... la Corte decidió que las reglas de legitimación desarrolladas junto con la jurisdicción epistolar no eran suficientes para los propósitos que se habían fijado. La Corte consideró que también era muy importante crear nuevos instrumentos para recabar la información requerida para decidir sobre un caso. Para el tribunal, "no era realista esperar que los demandantes con menos ventajas, o los activistas que trabajaban con ellos, proporcionaran la evidencia necesaria para que el tribunal decida" (Hunt, 1996: 165-6). Por esa razón decidió crear "comisiones socio-legales de información" destinadas a asumir la función de "comisarios de la Corte". (...) Por ejemplo, en Bandhua Mukti Morcha v. Union of India (2 S.C.R. 67, 1984) la Corte creó una comisión de investigación compuesta por miembros de la sociedad civil, con el propósito de asistirla en la implementación de las medidas que ordenaba. En Sheela Barse v. Union of India (3 S.C.R. 443, 1986), ella organizó también un comité para asegurar el cumplimiento de sus decisiones (ver Scott y Macklem, 1992).
\end{abstract}

Enfatiza-se que não se está a defender posições progressistas como essas para o Brasil, no entanto, parece ser de extrema valia meditar sobre as possibilidades que se abrem quando a Justiça decide contribuir para uma maior aproximação com a sociedade civil. A postura do Supremo Tribunal Federal depois das decisões de 2007 indica que essa meta é uma utopia bastante factível. Essas considerações talvez estimulem outros ramos do Estado a debater assuntos de interesse público não só com a sociedade, mas também com os outros Poderes. Foi o que a Corte indiana fez ao deixar de anular uma lei polêmica para colaborar com o Congresso, juntamente com o colégio de advogados, em sua nova redação. Esse talvez tenha sido o exemplo mais eloqüente de desformalização do sistema de repartição de competências e de respeito ao Direito material. Eis resumidamente o caso, relatado pelo constitucionalista argentino:

Una segunda característica innovadora de la Corte en la India (ya evidente en el
comentario anterior) fue la manera en que desafió, explícitamente, los supuestos
tradicionales vinculados con la separación de poderes. De acuerdo con las
nociones más comunes al respecto, se espera que la Corte asuma una actitud
reverencial ante las decisiones de las ramas políticas, excepto cuando ocurren
graves violaciones de la ley.
Contra ese punto de vista, la Corte india tuvo un papel más "agresivo", e intentó
colaborar activamente con las ramas políticas en la creación de decisiones más
imparciales. Por ejemplo, en el caso de Azad Rickshaw Pullers Union contra
Punja la Corte decidió no anular una polémica ley, sino colaborar con el
Congreso en su nueva redacción, a fin de crear una norma más adecuadamente
inclusiva. Según la opinión de la Corte, ella y los abogados acordaron sobre este

127 GARGARELLA, Roberto. ¿Democracia deliberativa y judicialización de los derechos sociales?. Disponível em: <http://www.calz.org/shop/detallenot.asp?notid=956>. Acesso em: 29 nov. 2008. 
enfoque constructivo y se esforzaron, luego de varias marchas y contramarchas, en modelar un nuevo proyecto legal. ${ }^{128}$

\section{Outro exemplo eloqüente de ativismo positivo do Poder Judiciário acontece,} segundo Cass Sunstein, na África do Sul. Gargarella, relatando as afirmações do professor emérito de Jurisprudência da Escola de Direito e do Departamento de Ciências Políticas da Universidade de Chicago, comenta que,

Para este autor, reconocer la existencia de ciertos "compromisos" constitucionales respecto a los derechos sociales, y - añadiría, siguiendo su análisis- el hecho de que los jueces tomen ciertas medidas específicas para la aplicación de esos derechos, puede ayudar a "promover la deliberación democrática, antes que socavarla, al dirigir la atención pública a intereses que de otra manera serían ignorados en la vida política diaria". La perspectiva de Sunstein surgió después de estudiar las decisiones de la Corte Sudafricana postapartheid, mismas que le indicaron que la Corte podía optar por un "tercer camino" entre dos alternativas indeseables e injustificables, marcadas por el activismo ciego a las consideraciones democráticas y la pasividad ciega a sus consecuencias (Sunstein, 2004: 227).

(...)

El ejemplo de la jurisprudencia sudafricana ha tenido efectos revolucionarios, pues ha ayudado a que la comunidad legal mundial entienda que es posible apoyar al mismo tiempo un rol judicial activo en el área de derechos sociales y la primacía de las autoridades políticas. Dos de las decisiones más destacadas de la Suprema Corte en Sudáfrica, el caso Grootboom y el de las Campañas de Acción de Tratamiento, son muy ilustrativas. El primero remite a una querella presentada por 900 personas que vivían en condiciones de pobreza extrema en cabañas miserables y reclamaban por sus derechos de vivienda. Ante tal situación, la Corte Sudafricana le exigió al Estado crear un programa destinado a cumplir sus obligaciones constitucionales, incluyendo medidas razonables diseñadas para "proveer alivio a personas que no tienen acceso a la tierra, carecen de techo sobre sus cabezas y viven en condiciones intolerables".

El segundo caso se refiere al SIDA —uno de los problemas sociales más dramáticos que sufre el país- y versa sobre la decisión del gobierno de prohibir la distribución de una droga antiviral (el nevirapine) excepto en circunstancias especiales (que incluían, por ejemplo, la creación de centros especiales de investigación). Aquí la Corte afirmó que el gobierno tiene la obligación de "diseñar y poner en práctica, teniendo en cuenta los recursos a su disposición, un programa comprehensivo y coordinado para implementar progresivamente el derecho de mujeres embarazadas a tener acceso a servicios de salud para combatir la transmisión de madre a hijo del VIH".

En estos casos, las decisiones de la Corte fueron particularmente notables porque demostraron cómo, en la práctica real, era posible que los jueces contribuyeran a la discusión sobre asuntos públicos fundamentales, sin minar la democracia. La contribución de la Corte consistió no solo en abordar asuntos que las autoridades políticas no atendían (o lo hacían de manera incorrecta, por ejemplo discriminando a ciertos grupos), sino también en cómo lograrlo con respeto a la autoridad superior del pueblo y sus representantes. Como se observa, no fue necesario que la Corte impusiera sus opiniones a las autoridades políticas, definiendo, por ejemplo, cuales remedios debían ser aprobados. Sin embargo, es indudable que estas decisiones llegaron a promover una discusión que, hasta ese momento, no existía o se malograba, y así obligaron a que los políticos asumieran responsabilidades que habían rehusado. La Corte realizó con ello un

128 GARGARELLA, Roberto. ¿Democracia deliberativa y judicialización de los derechos sociales?. 
valioso esfuerzo dirigido a la "inclusión" social de personas que hasta entonces se habían marginado de la conversación pública.

De fato, a adoção de soluções desse tipo é perfeitamente possível, sem risco de invasão indevida de competência. Note-se que em nenhuma delas a Suprema Corte impôs a sua própria solução para o caso. Se isso tivesse acontecido, a intromissão seria rigorosamente indevida, visto que estaria substituindo o juízo de valor exclusivo do Legislativo pelos seus próprios standards. A determinação para que o Estado criasse os programas necessários para analisar e efetivar as medidas possíveis para minorar os sofrimentos de grupos carentes e marginalizados promoveu o debate público sobre as questões dos miseráveis sem teto e das mães portadoras do vírus HIV que não tinham acesso a remédios capazes de preservar a imunidade de seus fetos.

Faz-se uma observação paralela com as determinações do Tribunal de Contas para que o governo procedesse a estudos para estabelecer uma adequada tarifa social de energia e soluções para as dificuldades ocorridas no episódio da recente crise por que passou o setor aéreo, especialmente no que diz respeito às condições operacionais dos equipamentos de radar e de controle de aproximação nos aeroportos de grande movimento. Quando a Corte de Contas questionou o perfil do quadro de servidores da INFRAERO e da ANAC pelo prisma da remuneração e qualificação profissional, não estabeleceu determinação diversa das proferidas pela Suprema Corte da África do Sul.

Por que essa solução não poderia ser imposta, como fez o Tribunal de Contas, pelo Judiciário? Não se nos afigura invasiva a determinação, nem excessiva a fixação de penalidade pelo descumprimento da obrigação de fazer. Estudos e planejamentos para resolver a questão, na medida do possível, são uma determinação irrecusável. Note-se que a decisão judicial não comporta a simples argüição da cláusula do financeiramente possível para, com a costumeira inércia governamental, mumificar situações de vida e de morte indignas.

Para finalizar a demonstração de que o Poder Judiciário pode, tanto ou mais que a Corte de Contas, já que fixa penalidades para o descumprimento da determinação, demonstrar o seu compromisso com a democracia deliberativa, trazemos as experiências da Colômbia no campo dos direitos sociais:

La Corte demostró su valor y compromiso con la democracia deliberativa en diversas decisiones mediante las cuales anuló leyes aprobadas sin debate público, o que no habían sido el producto de un proceso razonable de deliberación pública. Un ejemplo extraordinario es su decisión, en el 2004, de anular el llamado estatuto anti-terrorista, que representaba una parte importante de la 
agenda política del poder ejecutivo. La Corte tomó esa decisión cuando comprendió que más de una docena de legisladores que habían votado por el polémico estatuto habían cambiado de opinión de un día para otro, sin dar ninguna explicación pública sobre dicha actitud.

El compromiso de la Corte colombiana con la democracia deliberativa se torna evidente en su extensa jurisprudencia sobre derechos sociales, particularmente en la nueva y compleja doctrina desarrollada por la Corte, que se conoce como "la modulación de los efectos de las decisiones". De acuerdo con el juez Cepeda, el propósito general de estos juicios constitucionales moduladores surge como una "forma de armonizar la necesidad de preservar la Constitución con el alto respeto de la Corte hacia las decisiones de la legislatura. Es por medio de esas decisiones 'moduladoras' que la Corte intenta mantener la validez constitucional de las leyes, en la medida en que ello sea posible" (Cepeda, 2004: 566). Las decisiones moduladoras pueden ser de diferente tipo: "interpretativas", "expresamente integrativas" y "materialmente expansivas". También pueden estar relacionadas con el momento en el que las decisiones del tribunal tienen efecto.

En algunos casos la Corte pospuso el efecto de sus decisiones, bajo el supuesto de que su aplicación inmediata podría poner en peligro otros valores constitucionales fundamentales. Por ejemplo, en su famosa decision T-153 (1998), referente a los graves abusos cometidos por el personal público dentro de las prisiones, la Corte reconoció la validez de las quejas de los prisioneros, pero estableció que el gobierno tendría cuatro años para corregir la situación.

De igual modo, también la Corte reconoció que el Congreso, y no el poder judicial, era la instancia responsable para decidir la manera en la que se pondría fin a esos fuertes abusos. La Corte sugirió una estrategia similar en otra difícil decisión, la T-025 (2004), relativa al asunto de los desplazados, o sea a las poblaciones expulsadas de su lugar de residencia debido a la violencia política. La Corte consideró que la política del gobierno para los desplazados era inconstitucional en razón de su profunda insuficiencia e ineficacia, pero, aun así, no intentó imponer una ruta alternativa a la de las autoridades públicas. En contraste, la Corte afirmó que haría un seguimiento cercano al tema para asegurarse que estas decisiones estuvieran de acuerdo con la Costitución y fueran capaces, al mismo tiempo, de solucionar la situación desesperada de los desplazados. En todos estos casos la Corte se mostró capaz de intervenir de manera sumamente respetuosa hacia la autoridad de los legisladores.

Estos ejemplos ilustran algunas de las diversas formas en las que los tribunales pueden actuar para asumir una actitud fuerte y agresiva en lo concerniente a los derechos sociales y, al mismo tiempo, respetar su compromiso con la democracia deliberativa. $^{129}$

Nesse texto, Gargarella ressalta a inteira adesão do Judiciário colombiano à democracia deliberativa, que se caracteriza justamente por uma intensa cooperação entre os Poderes constituídos e a sociedade, ao proferir decisões moduladoras, é dizer, determinações que devem ser obrigatoriamente cumpridas na medida do possível. Explicase. Essas decisões podem ser interpretativas, integrativas ou materialmente expansivas. Podem ser também prospectivas, no sentido de que devem ser cumpridas no momento oportuno, fixado em prazo determinado ou estimado pelo magistrado. A decisão é modular porque estabelece uma medida arbitrária para regular situações insustentáveis que não podem ser prontamente corrigidas. Em vez de quedar-se inerte, a Corte colombiana proferiu decisão que não afrontou as normas de competência e, ao mesmo tempo,

${ }^{129}$ GARGARELLA, Roberto. ¿Democracia deliberativa y judicialización de los derechos sociales?. 
amenizou, na medida do possível, a situação desesperadora de comunidades carentes. Exemplo notável dessa técnica foi a decisão da Suprema Corte da Colômbia que, diante dos abusos dos servidores públicos encarregados de administrar os presídios, reconheceu a legitimidade das queixas dos detentos, mas estabeleceu um prazo de quatro anos para o Poder Público sanear o a situação.

Desse modo, a Justiça da Colômbia não atropelou o sistema normativo vigente, mas produziu uma norma concreta capaz de alterar uma situação de indignidade que não podia continuar. Para garantir a eficácia de sua decisão, a Corte afirmou expressamente que acompanharia o desenrolar dos fatos para verificar se a decisão estava sendo cumprida.

Enfatiza-se que a decisão requeria cumprimento imediato, já que o governo deveria, imediatamente, proceder a estudos e planos para mudar a situação impugnada pela Corte e que a solução encontrada se afastou notavelmente da posição tradicional que apenas reconhece a impossibilidade financeira de alterar os fatos tidos como inconstitucionais. Aqui, no Brasil, em lugar de resolver a questão na medida do possível, o Judiciário sistematicamente a encerra com uma enfática declaração de que não há nada a ser feito diante da comprovação de insuficiência de recursos financeiros.

Pergunta-se, então: qual das duas formas de decidir - a da Colômbia e a do Brasil cumpre mais fielmente a determinação constitucional de portar-se como Estado Democrático de Direito, cujo fundamento essencial reside na cidadania e na dignidade da pessoa humana? Reconhecer a cláusula do financeiramente possível para determinar ao governo que realize estudos e planos para ir cumprindo a condenação imposta em um prazo determinado parece ser a única solução que se aproxima do respeito à dignidade da pessoa humana. Certamente, também é a solução que se harmoniza com os seis primeiros artigos da Constituição Federal.

\subsection{CONTROLE SOCIAL DE POLÍTICAS PÚBLICAS E LEGITIMAÇÃo NAS AÇõES COLETIVAS}

Estabelecida a relevância do papel que pode ser atribuído ao Poder Judiciário no controle de políticas públicas, sem ofensa às atribuições privativas do Legislativo, cabe investigar se a solução proposta pode ser implementada com o sistema processual vigente ou seria indispensável uma reformulação significativa no sistema normativo para evitar uma sub-representação de importantes setores da sociedade. O receio é que os processos sociais de decisão continuem a privilegiar setores influentes da sociedade, em detrimento 
de grupos de desvalidos. A sociedade de empresários, ${ }^{130}$ como é sabido, com as doações de campanha estabelecem um pacto prévio de representação completamente oposto aos interesses das camadas mais pobres da população. $O$ raciocínio é simples, a representatividade política é tributária, principalmente, do poder econômico. Nesse sentido, as ações coletivas, exatamente por sua restrita forma de legitimação processual, têm um alcance social inversamente proporcional às novas experiências jurisprudenciais relatadas. Da forma como concebido, o sistema produz litígios de grupos de interesses, majoritários ou não, contra o Estado, não do povo contra o Estado. Como se sabe, o sistema nacional de legitimidade processual seguiu um critério estritamente seletivo e de concentração na instituição do Ministério Público, em detrimento do acesso irrestrito à Justiça.

Por mais diligente que se apresente e por mais relevante que seja a sua atuação, a experiência demonstra que a ação do Ministério Público é incapaz de assumir a pressão que, potencialmente, a sociedade poderia exercer se fosse admitida como protagonista na discussão dos problemas que a afetam diretamente. A posição de espectador, a experiência histórica bem o demonstrou, não lhe cai bem. Abdicamos não só de resultados, mas de formação de uma cidadania responsável. À evidência, a sub-representação nunca esteve em declínio com a ação do Ministério Público, notoriamente insuficiente para a caracterização de uma democracia deliberativa.

O sistema de acesso à jurisdição foi instituído para o absoluto respeito aos interesses individuais, espaço no qual, mesmo irrenunciáveis, os direitos não ultrapassam a órbita pessoal do litigante. Em se tratando de direitos sociais, o bem comum é conformado na órbita dos direitos disponíveis das relações de mercado, sujeito que está a todas as interferências externas, até mesmo de entidades, economias e Estados estrangeiros.

As ações coletivas, tal como instituídas, atendiam plenamente às necessidades sociais, até que o Estado tornou-se um implementador de políticas públicas no final do século XX. Carlos Alberto de Salles sustenta com bastante propriedade que

\footnotetext{
a questão da legitimidade para defesa de interesses de natureza coletiva incorpora um duplo problema de políticas públicas, consubstanciado em dois objetivos que podem ser colocados separadamente: um objetivo, propriamente processual, de alargamento do acesso à justiça; outro, de política institucional, no sentido de gerar condições para que aqueles interesses possam ser efetivamente representados. ${ }^{131}$
}

130 A expressão é utilizada, em diversos trabalhos, pelo Professor Regis Fernandes de Oliveira.

131 SALLES, Carlos Alberto de. Políticas públicas e processo: a questão da legitimidade nas ações coletivas. In: BUCCI, Maria Paula Dallari (Org.). Políticas públicas: reflexões sobre o conceito jurídico, p. 179. 
$\mathrm{O}$ aspecto processual, de alargamento do acesso à Justiça, é um problema de lege ferenda e, também, de uma nova posição de responsabilidade a ser assumida pelo Judiciário, tal como abordado no item precedente. Como sustentamos, ainda que abreviadamente, esse Poder não precisa senão ocupar um espaço que não lhe é vedado. Basta, nessa ótica, vontade política de comprometer-se com os destinos da coisa pública. É claro que medidas legislativas facilitariam sobremodo o trabalho, mas as posições assumidas pelo Supremo Tribunal Federal desde 2007, de vontade política participativa, demonstram que é suficiente para a Justiça sair da mesmice em que se encontra e comandar uma nova era no controle social das políticas públicas e na formação de uma consciência cívica indispensável para a integração de camadas não representativas da sociedade.

Comprovando a desnecessidade de alteração legislativa para ampliar a legitimação para ajuizamento de ações coletivas, ressaltamos que a própria Constituição Federal concedeu ao Judiciário permissão para, em alguns casos, apreciar o mérito do ato administrativo. No exato momento em que o constituinte admitiu como causa de nulidade do ato a existência de lesão ao patrimônio público e à moralidade administrativa, considerou o requisito da ilegalidade como não-essencial. Analisando o art. $5^{\circ}$, LXXIII, da Constituição, percebe-se que o controle da moralidade administrativa não pode ser feito sem o exame do mérito do ato. Em decorrência, não se pode dizer, desde então, que o mérito do ato administrativo não pode ser sindicado pelo magistrado.

\footnotetext{
Art. $5^{\circ}$ Todos são iguais perante a lei, sem distinção de qualquer natureza, garantindo-se aos brasileiros e aos estrangeiros residentes no País a inviolabilidade do direito à vida, à liberdade, à igualdade, à segurança e à propriedade, nos termos seguintes:

(...)

LXXIII - qualquer cidadão é parte legítima para propor ação popular que vise a anular ato lesivo ao patrimônio público ou de entidade de que o Estado participe, à moralidade administrativa, ao meio ambiente e ao patrimônio histórico e cultural, ficando o autor, salvo comprovada má-fé, isento de custas judiciais e do ônus da sucumbência;
}

No mesmo sentido, o art. $3^{\circ}$ da Constituição da República fixou os objetivos fundamentais da República Federativa do Brasil e foi muito além do preceito acima transcrito. Como a nossa República deve ser constituída sob a forma de Estado democrático de Direito (art. $1^{\circ}$ da CF) e o Estado social de direito só evolui para a forma democrática se os objetivos fundamentais previstos no art. $3^{\circ}$ da $\mathrm{CF}$ forem observados, a 
ausência ou a inadequação de metas e programas potencialmente capazes de transformar a realidade fática exigem uma pronta resposta do Poder Judiciário.

Tercio Sampaio Ferraz releva que o Estado liberal exigia que o Poder Judiciário fosse neutro em relação aos demais Poderes, mas essa situação foi profundamente alterada a partir de 1988, já que ele precisa estar permanentemente alinhado com os fins do Estado e com uma política estatal correta. Enfatiza-se, por oportuno, que a neutralidade aludida não lhe retira o caráter de Poder neutral, uma vez que restringe-se a uma isenção política.

Resta apenas observar que este Poder necessita de uma provocação para agir. Por isso que torna-se imprescindível aceitar a abertura concedida pelo inciso LXXIII do art. $5^{\circ}$ da Constituição Federal e aceitar que o cidadão, isoladamente, possa recorrer ao Judiciário para exigir o cumprimento dos objetivos fundamentais relacionados no art. $3^{\circ}$ da Carta.

Uma excelente forma de alcançar esse objetivo, independentemente de ações legislativas, seria uma criteriosa utilização da figura do amicus curiae, prevista na Lei $\mathrm{n}$. 9.868/99, ${ }^{132}$ e de audiências públicas com órgãos notoriamente especializados como o Tribunal de Contas. Relembramos que a Lei n. 6.616/78, que alterou o disposto no art. 31 da Lei n. 6.386/76, criou a possibilidade de a Comissão de Valores Mobiliários (CVM) ingressar em feitos que tratem de questões ligadas às suas amplas competências para regular o mercado de capitais. ${ }^{133}$ De igual forma, o art. $5^{\circ}$, parágrafo único, da Lei n. 9.469/97 $7^{134}$ dispõe que pessoas jurídicas de direito público podem intervir em feitos que

132 Art. $7^{\circ}$ Não se admitirá intervenção de terceiros no processo de ação direta de inconstitucionalidade.

(...)

$\S 2^{\circ} \mathrm{O}$ relator, considerando a relevância da matéria e a representatividade dos postulantes, poderá, por despacho irrecorrível, admitir, observado o prazo fixado no parágrafo anterior, a manifestação de outros órgãos ou entidades.

133 Lei n. 6.386/76, art. 31 - Nos processos judiciários que tenham por objetivo matéria incluída na competência da Comissão de Valores Mobiliários, será esta sempre intimada para, querendo, oferecer parecer ou prestar esclarecimentos, no prazo de quinze dias a contar da intimação. (Incluído pela Lei n. 6.616, de 16.12.1978)

$\S 1^{\circ}$ A intimação far-se-á, logo após a contestação, por mandado ou por carta com aviso de recebimento, conforme a Comissão tenha, ou não, sede ou representação na comarca em que tenha sido proposta a ação. (Incluído pela Lei n. 6.616, de 16.12.1978)

$\S 2^{\circ} \mathrm{Se}$ a Comissão oferecer parecer ou prestar esclarecimentos, será intimada de todos os atos processuais subseqüentes, pelo jornal oficial que publica expedientes forense ou por carta com aviso de recebimento, nos termos do parágrafo anterior. (Incluído pela Lei n. 6.616, de 16.12.1978)

$\S 3^{\circ} \mathrm{A}$ comissão é atribuída legitimidade para interpor recursos, quando as partes não o fizeram. (Incluído pela Lei n. 6.616, de 16.12.1978)

$\S 4^{\circ} \mathrm{O}$ prazo para os efeitos do parágrafo anterior começará a correr, independentemente de nova intimação, no dia imediato aquele em que findar o das partes.

134 Art. $5^{\circ}$ A União poderá intervir nas causas em que figurarem, como autoras ou rés, autarquias, fundações públicas, sociedades de economia mista e empresas públicas federais.

Parágrafo único. As pessoas jurídicas de direito público poderão, nas causas cuja decisão possa ter reflexos, ainda que indiretos, de natureza econômica, intervir, independentemente da demonstração de interesse jurídico, para esclarecer questões de fato e de direito, podendo juntar documentos e memoriais 
possam apresentar reflexos, ainda que indiretos, de natureza econômica, independentemente da demonstração de interesse jurídico.

Não há, então, razão plausível para exigir a edição de uma lei específica para guindar o Tribunal de Contas à posição de consultor do juízo que precisa decidir complexas questões econômicas de interesse do Estado, não somente para manifestações como também para apresentação de eventuais recursos. Saliente-se, nesse sentido, que mesmo antes da Lei n. 9.868/99 a admissão do chamado amicus curiae já havia sido admitida pelo Supremo Tribunal Federal Tribunal, conforme voto do Min. Celso de Mello:

O processo de controle normativo abstrato instaurado perante o Supremo
Tribunal Federal não admite a intervenção assistencial de terceiros. Precedentes.
Simples juntada, por linha, de peças documentais apresentadas por órgão estatal
que, sem integrar a relação processual, agiu, em sede de ação direta de
inconstitucionalidade, como colaborador informal da Corte (amicus curiae):
situação que não configura, tecnicamente, hipótese de intervenção ad
coadjuvandum.

Com a abertura inscrita na Lei n. 9.469/97 a legitimidade do Tribunal de Contas para ingressar nos feitos de interesse econômico afeto às suas competências técnicas não depende mais da demonstração de seu eventual interesse jurídico, porquanto "trata-se, em casos que tais, de um interesse jurídico que transcende o indivíduo ou a entidade que busca a intervenção. A hipótese em estudo refere-se, inequivocamente, a uma dessas situações. De interesse institucional se ocupa o dispositivo em questão, portanto". ${ }^{136}$

De qualquer forma, a solução ideal para esse problema nunca sairá diretamente dos corredores do palácio do governo nem dos gabinetes do Congresso Nacional. Fechando o circulo da análise, verificamos que a sub-representação não pode ser eficientemente combatida sem a participação do povo, se devidamente informado e provocado pela repercussão da atividade diária dos Tribunais e do Tribunal de Contas nos meios de comunicação. Na era da informática, a toda evidência, o controle social fica a cada dia mais relevante e temido pelos governantes.

reputados úteis ao exame da matéria e, se for o caso, recorrer, hipótese em que, para fins de deslocamento de competência, serão consideradas partes.

135 STF. Agr. Reg. na ADI n. 748-4, Rel. Min. Celso de Mello, DJ 18.11.94, p. 31392.

136 BUENO, Cássio Scarpinella. Amicus curiae no processo civil brasileiro: um terceiro enigmático. São Paulo: Saraiva, 2006, p. 140. 


\subsection{POLÍTICAS PÚBLICAS E O TRIBUNAL DE CONTAS. PODER NEUTRAL}

A primeira questão a ser abordada em tema de controle social de políticas e ação do Tribunal de Contas é a sua natureza de poder neutral. A teoria dos poderes neutrais, de antiga concepção, tem sido invocada com êxito para atribuir poderes de controle a entes estatais que não integram, formalmente, nenhum dos três Poderes constituídos. A propósito, reafirmamos o que foi dito no item 6.6, no sentido de que o verbo auxiliar não implica subordinação ao Poder legislativo. A Constituição não utiliza a expressão órgão auxiliar, apenas prescreve que o controle externo, a cargo do Congresso Nacional, será exercido com o auxílio do Tribunal de Contas da União. O Tribunal de Contas é órgão da União, autônomo, e não pertence a nenhum dos três Poderes.

Pensava-se, a princípio, que somente os órgãos ocupados por mandatários eleitos pelo povo possuíam legitimação para expressar a soberania e vontade popular, mas logo se percebeu que o título formal de legitimação popular não era suficiente para emprestar competência técnica, científica e intelectual a todos os ocupantes de cargos e funções estatais. A organização estatal democrática reclamava a criação de cargos que não devem ser preenchidos por meio de eleições, mas por pessoas qualificadas tecnicamente, com atribuições autônomas, independentes, e imunes aos interesses eleitorais passageiros, que podem, em tese, ser alterados de acordo com as circunstâncias. Assim surgiram os poderes neutrais do Estado, como o Banco Central, a CVM, Tribunais de Contas, CADE e, mais recentemente, as agências reguladoras. A doutrina elaborou os conceitos desses poderes independentes como sendo uma Teoria dos Poderes Neutrais, que tem por síntese a necessidade da existência de entes estatais que não se submetem hierarquicamente a nenhum dos três Poderes, com vistas à plena realização da democracia, de modo a assegurar o pluralismo de interesses na sociedade sem as naturais pressões que as decisões de efeitos políticos ocasionam.

Os poderes neutrais, como já foi dito, podem ser definidos como verdadeiros anticorpos contra os órgãos políticos, porquanto atuam por meio da substituição de decisões político-partidárias por decisões de natureza técnica. Eles completam o sistema de freios e contrapesos e tornam possível suprir a incapacidade desse sistema de reger as relações entre os três Poderes de forma harmônica. A sua missão é neutralizar os centros do poder dominante, imunizando-os dos efeitos que podem advir de decisões precipitadas em que o elemento político suplanta irracionalmente o técnico e o jurídico. Por outro lado, o fato de serem contínuos, independentes, e autônomos - no sentido de que não estão 
sujeitos à influência do poder político momentaneamente dominante nem têm de se ajustar aos critérios das administrações que se renovam a cada quatro anos - assegura que a opinião pública não seja um obstáculo intransponível para a edição de medidas impopulares.

Alexandre Santos Aragão, com base na doutrina internacional, informa que a essência dos poderes neutrais reside precisamente no caráter formalmente não-político de suas decisões e não no aspecto materialmente não-político de sua atuação:

\begin{abstract}
Condensando as características dos poderes neutrais, SILVIA NICCOLAI os conceitua como "aquelas instituições destinadas a tutelar valores frente à direção política (indirizzo politico) do Estado, e que, em consequiência, situam-se em área distinta da dos órgãos titulares das funções de direção política". Não se trata de afirmar que as funções dos poderes neutrais sejam desvestidas de qualquer matiz político, mas o que é mais importante para a sua caracterização não é "o caráter substancialmente não político das suas decisões, mas o caráter formalmente não político destas", o que é evidenciado pelo caráter não eletivo dos seus titulares (...). ${ }^{137}$
\end{abstract}

É intuitivo que o órgão controlador de políticas públicas não pode estar vinculado ao Executivo, que as implementa, nem ao Legislativo, que as institui nas normas orçamentárias e em leis específicas. O produto do consenso a que chegaram, Legislativo e Executivo, não sofreria qualquer correção de possíveis equívocos originários se as avaliações de mérito continuassem a ser objeto de suas próprias atribuições. Nesse sentido, o Tribunal de Contas, poder neutral, ajunta-se aos checks and balances dos Poderes instituídos para lançar novas luzes às políticas, ao mesmo tempo em que permite a introdução da sociedade no debate. Eventuais impasses, caso seja possível reduzir a questão política ao nível jurídico, podem ser dirimidos pelo Judiciário.

\title{
7.7 CONTROLE SOCIAL DE POLÍticas PÚblicas E O TRIBUNAL DE CONTAS
}

A Administração Pública no Brasil está bastante fragmentada e apresenta, no processo de elaboração e execução de políticas públicas, uma imprecisa atribuição de poderes ao Executivo e ao Legislativo. A iniciativa cabe ao Executivo, mas é o Legislativo que confere normatividade às políticas. Colocado o problema dessa maneira, as coisas parecem bem simples. Entretanto, como os programas podem se estender por várias

137 ARAGÃO, Alexandre Santos de. A legitimação democrática das agências reguladoras. In: BINENBOJM, Gustavo (Coord.). Agências reguladoras e democracia, p. 20. 
legislaturas e sofrer a constante influência de condições absolutamente imprevisíveis, eles demandam uma rápida correção de rumo se as previsões feitas na elaboração das políticas não se concretizarem. O Legislativo, tendo em vista o lento processo burocrático que o caracteriza, não poderia fazer as alterações necessárias para atualizar a forma como os programas devem se ajustar às novas condições de fato. Embora o Poder Legislativo não possa abdicar de suas competências, não se pode negar que não ficou em suas mãos senão a fixação das linhas gerais da política. Cada vez mais, o Executivo assume uma delegação de poderes de difícil delimitação. Fábio Konder Comparato há muito notou a transferência consentida de poderes do Legislativo ao Executivo, em razão de uma capacidade normativa de conjuntura:

\begin{abstract}
Acontece que não foi apenas pela forma de governar que o Estado contemporâneo reforçou os poderes do ramo executivo. Foi também pelo conteúdo da própria ação governamental. Doravante e sempre mais, em todos os países, governar não significa tão-só a administração do presente, isto é, a gestão de fatos conjunturais, mas também e sobretudo o planejamento do futuro, pelo estabelecimento de políticas a médio e longo prazo. ${ }^{138}$
\end{abstract}

Nesse caso, o poder regulamentar atribuído ao Executivo não se limita tão-só a conferir concreção das prescrições legais à realidade social e econômica, ou seja, tem em vista a ordenação de situações estruturais. Em vez disso, o Executivo passa a exercer função normativa para regular situações conjunturais de extrema relatividade. Se o estado de exceção provoca a suspensão do Direito para solucionar questões de fato imprevisíveis, com vistas ao mais breve retorno à normalidade, a capacidade normativa de contingência atribui competência a quem não a possuía antes dos fatos excepcionais. O estado de exceção é provisório e informal, a capacidade normativa de emergência é duradoura e legitima extraordinariamente a competência atribuída ao Executivo.

Eros Grau formulou os seguintes ensinamentos sobre essa competência de conjuntura:

\footnotetext{
Observei, em outra ocasião (1977/48-49), que à compreensão de que o processo de desenvolvimento implica uma dinâmica mobilidade social corresponde a adoção de uma nova visão da realidade, prospectiva, acompanhada do repúdio a concepções que divisavam na norma jurídica - como o faziam Bouvier e Jèze - a "regra primordial e fundamental que rege as relações sociais no interior do Estado, de um modo geral e permanente (ou perpétuo)". Descortina-se, assim, a evidência de que o direito - tal como o divisou Von Ihering, em sua teoria organicista - necessita, como todo organismo vivo, estar em constante mutação, impondo-se a superação do descompasso existente entre o ritmo de evolução das
}

138 COMPARATO, Fábio Konder. Para viver a democracia, p. 102. 
realidades sociais e a velocidade de transformação da ordem jurídica. Nesse clima, a instabilidade de determinadas situações e estados econômicos sujeitos a permanentes flutuações - flutuações que definem o seu caráter conjuntural -, impõe sejam extremamente flexíveis e dinâmicos os instrumentos normativos de que deve lançar mão o Estado para dar correção a desvios ocorridos no desenrolar do processo econômico e no curso das políticas públicas que esteja a implementar. Aí, precisamente, o emergir da capacidade normativa de conjuntura, via da qual se pretende conferir resposta à exigência de produção imediata de textos normativos, que as flutuações da conjuntura econômica estão, a todo o tempo, a impor. ${ }^{139}$

Como se percebe, há um ponto em que fica difícil reconhecer a mão do legislador na política, tal é o grau da alteração imposta ao projeto inicial. Não há, então, parâmetros objetivos para efetuar um controle efetivo sobre as políticas. Se a situação econômicosocial não é mais a mesma, as verbas previstas já foram desviadas para emergências mais prementes ou simplesmente não existem mais, o plano plurianual, as diretrizes orçamentárias e os orçamentos anuais também não, como avaliar políticas e programas diante dessas mutações? Os parâmetros, como se disse, perderam-se no curso das crises que sufocam a Administração. Nau sem rumo, os programas, mesmo os fixados em décadas, passam a ter a sua direção improvisada, conforme a vontade política do gerenciador das crises. Já que tudo passa a ser conjuntural, como avaliar e corrigir políticas pelos mesmos padrões de legalidade estrita? Parece ser de clareza solar que o Legislativo, diante da relatividade de sua obra original e da competência normativa de conjuntura adquirida pelo Executivo, não poderia retomar as rédeas das políticas que se desviaram do curso original sem assumir, ele próprio, o controle das voláteis situações conjunturais. Isso certamente paralisaria todos os projetos até novas deliberações em plenário. Por outro lado, o Executivo passa a não ser controlado por ninguém, até que os erros cometidos sejam percebidos. Seria admissível, nessa senda, que apenas a história julgasse os responsáveis pela má-gestão? Essa é exatamente a razão pela qual invocamos no primeiro capítulo a metáfora do legista, que somente analisa e explica as origens e conseqüências do dano consumado em relação ao corpo necropsiado, para definir a ação nada reparadora dos mecanismos utilizados no controle de políticas públicas.

Diante desse quadro, a conclusão não poderia ser outra além de reconhecer que a necessidade e o imponderável atropelaram de tal forma os esquemas de atribuições de competências e divisão de poderes que não é mais possível sustentar que os tradicionais métodos de controle de políticas públicas continuam intocáveis. A solução para esse problema reside na introdução da sociedade para assumir uma posição de destaque no

139 GRAU, Eros Roberto. o direito posto e o direito pressuposto. 3. ed. São Paulo: Malheiros, 2006, p. 172. 
controle social eficaz que propusemos ao longo do trabalho. Demonstramos as promissoras possibilidades de utilizar o Poder Judiciário como órgão provocador do esperado ativismo da sociedade e concluímos que o principal papel nesse novo controle social está reservado ao Tribunal de Contas. Resta, então, ainda que sucintamente, analisar como a proposta pode ser concretizada em relação à Casa de Contas.

Por que o Tribunal de Contas? Porque no momento histórico atual é o ente público de maior significação científica para a missão, além de ser órgão neutral por excelência, já que possui estatura constitucional e está autorizado a realizar auditorias operacionais e gerenciais. Além das auditorias financeiras e orçamentárias, que tratam dos exames de contratos, registros, sistemas contábeis e informações financeiras em geral, inclusive pelo prisma de conformidade com o ordenamento jurídico, o Tribunal ocupa-se, desde 1988, da eficiência, eficácia e efetividade dos programas de governo, assim como do modo como a auditoria operacional pode ser aperfeiçoada. Embora a Constituição de 1967 fizesse referência à sua atribuição de controlar a operacionalidade da gestão estatal, somente na Constituição de 1988 a matéria foi claramente disciplinada para alcançar a operacionalidade de políticas e programas de governo.

É verdade que o potencial do Tribunal de Contas tem sido subutilizado, já que não temos uma cultura formada para extrair de sua capacitação técnica os benefícios possíveis. Para demonstrar o equívoco de enxergar no Tribunal apenas as suas competências de controle financeiro, ressaltam-se a surpresa que a sua atuação causou no episódio da endêmica crise aérea que passamos e as suas reiteradas recomendações e determinações feitas ao Ministério da Defesa acerca das condições operacionais dos equipamentos de radar e de controle de aproximação nos aeroportos de grande movimento, bem como da identificação do perfil do quadro de servidores da INFRAERO e da ANAC pelo prisma da remuneração e qualificação profissional. Com que autoridade o Tribunal questionou, também, os critérios utilizados pelo Ministério de Minas e Energia para o enquadramento dos consumidores da subclasse baixa renda nos benefícios da tarifa social de energia?

A primeira vez que o Tribunal foi chamado para avaliar um programa de políticas públicas durante sua implantação foi no Programa Fome Zero, implantado pelo Governo Federal a partir de 2003. A proveitosa participação do Órgão de Contas com o Ministério da Segurança Alimentar e Combate à Fome foi determinante para a elaboração desta tese, no sentido de provocar uma reflexão mais aprofundada de suas potencialidades no controle de políticas públicas. Acreditamos que, se esses controles forem realizados com 
habitualidade e se receberem divulgação necessária para atrair a sociedade para as questões debatidas, será possível começar a conformar uma sociedade responsável e participante.

Diante da percepção de que a longa e grave crise econômica mundial requer medidas urgentes para estancar a sangria que a corrupção, as fraudes, os desvios ilegais e o notório desperdício de dinheiro público provocam, as Entidades de Fiscalização Superior (EFS) de todo mundo aperfeiçoaram condutas objetivas para controle de resultados, que excedem notavelmente o arcaico controle de legalidade. A EFS nacional, o Tribunal de Contas da União, é a única entidade com capacitação profissional de seus auditores que está sempre em contato com as modernas experiências implantadas em suas símiles estrangeiras.

Para se ter uma idéia aproximada da alta especialização necessária para efetuar uma auditoria operacional de programas governamentais, sintetizamos, a seguir, as diversas etapas dessa verificação e as técnicas comprovadas internacionalmente para esse trabalho. O ciclo da Auditoria de Natureza Operacional, conforme consta no site do Tribunal de Contas da União, compreende as seguintes fases: seleção, planejamento, execução, análise, elaboração de relatório, comentário do gestor, apreciação pela Corte, divulgação e monitoramento.

O primeiro passo para a auditoria é a seleção dos programas. Nessa fase, os programas a serem avaliados são examinados a partir de prioridades de governo, relevância dos projetos para potencialmente reduzir os problemas da sociedade, grandeza dos recursos alocados e risco de não se alcançar os resultados esperados. Depois disso, os programas selecionados são submetidos a estudos de viabilidade, momento em que são examinadas a oportunidade e a modalidade da fiscalização que se apresenta mais adequada à auditoria, tendo em vista os problemas que podem comprometer o seu desempenho.

A fase seguinte, de planejamento, ocupa-se da identificação dos fins da auditoria e de seus objetivos imediatos e mediatos, assim como da fixação dos procedimentos e técnicas a serem utilizados na colheita de informações. Nessa fase o Tribunal define o projeto de auditoria e sintetiza tudo aquilo que constará no instrumento denominado matriz de planejamento. Para isso, aplicam-se complexas técnicas para diagnosticar e identificar as principais razões que podem prejudicar o resultado aguardado do programa, especialmente em relação a sua economicidade, eficiência, eficácia e efetividade. A fase de planejamento apresenta, para cada questão avaliada na auditoria, as informações necessárias para a sua análise; onde serão obtidas as fontes; a estratégia metodológica para colher e analisar informações; as limitações dela decorrentes; e os resultados esperados. 
$\mathrm{Na}$ execução, a auditoria dedica-se a trabalhos de campo e a pesquisas necessárias para coleta de dados, aplicação de questionários, observação direta, consultas a documentos, bases de dados etc. Em seguida, é elaborada a matriz de achados, síntese dos resultados obtidos, que servirá, juntamente com a matriz de planejamento, de base para discussão no Tribunal com a participação de representantes de grupos de interesse, como os órgãos de controle interno, entidades da sociedade civil, e consultorias legislativas do Congresso. As sugestões dos participantes são incorporadas à versão final dos documentos que serão apresentados aos gestores dos programas. Elaborado o relatório preliminar que será submetido ao gestor público para comentário, o Tribunal promove a mais ampla divulgação do relatório final, com vistas a promover o controle social das ações do governo. Nessa etapa de divulgação do relatório, a sociedade toma conhecimento dos resultados das ações estatais avaliadas e completa o círculo de controle inaugurado com a seleção dos programas. Para assegurar que as recomendações formuladas sejam cumpridas, o Tribunal monitora o cumprimento das recomendações feitas durante, em média, quatro anos.

Para comprovar a afirmação anteriormente feita de que, atualmente, só o Tribunal de Contas possui especialização e capacidade técnica para controlar políticas públicas, ressalta-se que esse órgão tem acesso a toda contabilidade oficial e possui formação específica internacionalmente aceita para essa avaliação. Desde 1998 o Tribunal vem se preparando para assumir o papel de controlador de gestões públicas. De abril de 1998 a maio de 2001, o Brasil participou de um acordo de cooperação técnica firmado com a Inglaterra e a Irlanda do Norte para implantar o Projeto de Desenvolvimento de Técnicas de Auditoria de Natureza Operacional, denominado Projeto TCU/Reino Unido, cujo objetivo residia no aperfeiçoamento do desempenho do setor público, implementação de uma ótima utilização de recursos, aperfeiçoamento da capacidade técnica no desempenho relacionado a auditoria operacional e avaliação de programa, além do acompanhamento da execução das recomendações feitas.

Esse projeto foi importante porque, em sua segunda fase, utilizou metodologias de avaliação de programa direcionadas especialmente aos problemas relacionados à pobreza e à desigualdade social. E o know-how adquirido foi extremamente relevante porque o Tribunal investigou com profundidade a eficácia das ações governamentais empregadas para reduzir a pobreza e a desigualdade. Implementou-se, então, o Projeto de Aperfeiçoamento do Controle Externo com foco na Redução da Desigualdade Social (CERDS). 
Enfatiza-se também o alto grau de sofisticação das técnicas internacionais solidamente consagradas, fato que demonstra a exclusiva capacidade técnica do Tribunal para avaliar os programas públicos. Nesse sentido, algumas técnicas ${ }^{140}$ utilizadas são de uso freqüente em entidades estrangeiras, como:

- Benchmarking, utilizado para identificar e implementar boas práticas de gestão;

- Indicadores de Desempenho e Mapa de Produtos, para aferir os resultados alcançados pelos administradores, metodologia largamente utilizada nos Estados Unidos, na Austrália e no Reino Unido;

- Mapa de Processos, que é uma representação de um processo de trabalho "por meio de um diagrama contendo a seqüência dos passos necessários à consecução de determinada atividade";

- Análise RECI, que consiste em "uma ferramenta que ajuda a identificar quem é responsável pelas atividades desenvolvidas, quem as executa, quem é consultado e quem é informado, seja no âmbito limitado de uma equipe de trabalho, seja em relação a um órgão, entidade ou programa;

- Marco Lógico, utilizado como "um modelo analítico para orientar a formulação, a execução, o acompanhamento e a avaliação de programas ou de projetos governamentais";

- Análise Stakeholder, que consiste na identificação dos principais atores envolvidos, dos seus interesses e do modo como esses interesses irão afetar os riscos e a viabilidade de programas ou projetos. Está ligada à apreciação institucional e à avaliação social, não só utilizando as informações oriundas dessas abordagens, mas também contribuindo para a combinação de tais dados em um único cenário;

- Análise SWOT, que “integra as metodologias de planejamento estratégico organizacional. A aplicação da técnica, segundo alguns autores, pode ocorrer quando do diagnóstico estratégico, após a definição da missão ou após o estabelecimento de objetivos. De qualquer forma, deve ser aplicada anteriormente à formulação estratégica de ação. Portanto, é uma ferramenta facilitadora do diagnóstico institucional, podendo ser usada também no âmbito da avaliação de programas. A análise SWOT foi desenvolvida pela escola do design, do grupo de administração geral da Harvard Business School. O modelo proposto pela escola é a 'formulação de estratégia que busque atingir uma adequação entre as capacidades

140 TCU. Disponível em: <http://portal2.tcu.gov.br/portal/page/portal/TCU/ comunidades/programas_governo/tecnicas_anop>. Acesso em: 8 dez. 2008. 
internas e as possibilidades externas'. Na análise das capacidades internas, busca-se identificar as forças e as fraquezas da organização, enquanto o ambiente externo no qual atua a organização deve ser analisado em termos das oportunidades e ameaças presentes.

Pode-se assinalar também a relevância da criação, no ano de 2000, da Secretaria de Fiscalização e Avaliação de Programas de Governo (SEPROG), que, segundo se vê no site do TCU, tem os seguintes objetivos:

I. atender às expectativas da sociedade e às do Congresso Nacional em relação à avaliação de programas de governo;

II. contribuir para maior transparência das ações governamentais, fortalecimento do controle social e maior impacto dos programas de governo;

III. manter-se na vanguarda de técnicas e metodologias de auditorias de natureza operacional;

IV. assegurar que as avaliações de programas de governo estejam relacionadas às áreas de maiores risco, relevância e materialidade;

V. contribuir para a expansão e o aperfeiçoamento da ação institucional de avaliar programas de governo;

VI. assegurar que os padrões de qualidade estabelecidos sejam atingidos e aumentar o impacto das auditorias.

Essas técnicas, como é intuitivo, não são ferramentas disponíveis, atualmente, para nenhuma outra entidade, por isso, justifica-se plenamente a opção que fizemos pelo Tribunal de Contas como órgão tecnicamente vocacionado para assessorar a sociedade em seu ingresso no debate de conveniência e oportunidade da implementação de políticas públicas.

\subsection{IMPORTÂNCIA DO ATO ADMINISTRATIVO DE ALERTA}

Entre as novas atribuições do Tribunal de Contas, previstas no art. 59 da Lei Complementar n. 101/2001, está instituído o mecanismo de alerta. Diante da ocorrência das hipóteses elencadas no $\S 1^{\circ}$ do art. 59 da Lei de Responsabilidade Fiscal, o Tribunal de Contas tem o dever de alertar as entidades referidas no art. 20 para sanar as irregularidades. Não há como negar que, nessas hipóteses, o controle do Órgão de Contas tem função cautelar preventiva. Por isso, é um eficaz meio de controle externo preventivo. Sucede, no entanto, que os alertas podem ser utilizados para matéria diversa da aí enumerada, pois, para efeito de emissão de alertas, qualquer irregularidade pode ser objeto dessa advertência. Se convenientemente utilizado, somente benefícios poderá trazer, não só ao 
interesse público, como também ao próprio órgão alertado, que deverá acautelar-se para corrigir as distorções ou preparar-se para a responsabilidade política que lhe poderá ser imputada. Tendo em vista que ele não envolve reprimenda, nem sanção, não nos parece que suscetibilidades exageradas sejam feridas. Como o alerta serve para fixar responsabilidades se não atendido, é um ato administrativo que deve ser praticado com todas as formalidades legais, como a devida publicação do ato, exatamente para informar a todas as pessoas sobre a possível ocorrência de irregularidades. Esta formalidade é de capital importância para a accountability.

Caso só fosse admitida a emissão de alertas para matérias expressamente relacionadas com responsabilidade fiscal, o controle social simplesmente não existiria, pelo menos não no âmbito requerido para um controle eficaz. 


\section{ORÇAMENTO PÚBLICO, PARTICIPAÇÃO POPULAR E PAPEL DO TRIBUNAL DE CONTAS NO CONTROLE SOCIAL DE POLÍTICAS PÚBLICAS}

Agora que a divisão de poderes, as normas de competência e as atribuições do Judiciário e do Tribunal de Contas foram analisadas até o limite de suas possibilidades, parece ter ficado razoavelmente demonstrado que as transformações operadas nas estruturas do Estado e do poder, com a devida assunção dos direitos humanos e dos princípios da democracia, da eficiência e da economicidade a um patamar de importância não previsto à época da Constituinte, especialmente no que tange a figuras jurídicas recentemente incorporadas em nosso Direito - como as políticas públicas e o remodelado poder normativo atribuído às agências reguladoras -, é de rigor exigir, ao lado de uma nova hermenêutica constitucional, uma nova visão para controle do orçamento.

A profunda crise econômica mundial e a inevitável recessão dela resultante acentuaram o estado de exceção em que vivemos e ressaltaram a pouca atenção que a doutrina dispensa à maneira como o dinheiro do orçamento é empregado ou dissipado. Nesse sentido, o Supremo Tribunal Federal sistematicamente não conhece de ações diretas de inconstitucionalidade que pretendem discutir dispositivos de leis orçamentárias. Com essa postura, tem oferecido um bill de indenidade à legislação orçamentária. Considerar, objetivamente, que os tipos orçamentários carecem de normatividade não presta obséquio a um controle minimamente moralizante dos gastos públicos. A temporalidade da lei orçamentária não retira a materialidade da norma que permite ao Presidente da República dispor de verbas comprometidas com políticas públicas tantas vezes quanto entender necessário. Essas freqüentes realocações impedem que se veja um determinado dispositivo de lei orçamentária como uma ação historicamente determinada e única, mas que completa um todo harmônico e incindível. Não se pode ver a parte pelo todo, mas é indispensável considerar que, alterando-a, desequilibra-se o conjunto e desfigura-se a proporcionalidade que lhe deu consistência. A escassez de verbas e a enormidade de projetos possíveis 
deixam antever que o produto final do orçamento não se descaracteriza somente com a supressão ou alteração impensada (não planejada em função do todo), mas com a inserção de planos ou distribuição de verbas que não se amoldam aos critérios determinantes da ordem de preferências estabelecida pelas urgentes necessidades públicas. Ainda que todas as ações sejam defensáveis e necessárias, é de clareza solar que a proporcionalidade das verbas, em consonância com a urgência das necessidades e a relevância de direitos e garantias protegidos, determina a relevância do orçamento.

Por esse foco, é forçoso partir da constatação de que o orçamento é muito mais que uma peça contábil, representa a promessa de justiça social e de dignidade de vida. Assim, não é possível obter êxito no combate ao desperdício, à corrupção e à ineficiência se impedirmos que o controle social possa alcançar todo o trâmite das leis orçamentárias, que é a fase em que elas tomam corpo e consumam a promessa irrenunciável e irrevogável do pacto social implicitamente acordado. Por isso, a aprovação dessas leis não pode prescindir de um prévio debate público, amplo e adequado. Acreditamos, nesse sentido, que os conhecimentos técnicos do Tribunal de Contas e uma ação mais ativa do magistrado podem facilitar a participação popular, no sentido de permitir a conclusão de uma peça verdadeiramente participativa e o pleno conhecimento, por parte de congressistas e governantes, das responsabilidades que podem resultar do desconhecimento de alertas e recomendações que o Tribunal vier a emitir.

A participação de que se fala não é a formal contribuição de pequenos grupos nãorepresentativos da sociedade, nem a crítica inconseqüente formulada a uma norma já vigente e eficaz, mas o clamor público manifestado durante o seu trâmite, favorável ou contrário à efetivação das verbas que compõem a previsão orçamentária. Essa participação, de escala muito mais abrangente e representativa da sociedade só será possível se o Tribunal de Contas, único órgão que possui aptidão técnica suficiente para estabelecer uma ponte entre a sociedade e os membros do Parlamento, assumir o papel que a Constituição expressa e implicitamente lhe atribuiu. Nessa perspectiva, sustenta-se que o Tribunal de Contas não auxilia somente os três Poderes constituídos, mas, principalmente, a sociedade.

Salienta-se, em especial, que a adoção de políticas públicas vincula todas as normas que, de algum modo, estão com elas relacionadas. Nesse aspecto, as leis orçamentárias não podem ser tratadas como peças sem importância. É no processo orçamentário que se tomam as decisões cruciais de vida e de morte, de progresso ou de barganha política imoral, de continuidade ou engessamento de políticas públicas em andamento ou a serem implementadas. Ora, se as leis orçamentárias definem os fins (objetivos) a serem 
alcançados, cuja fixação é decorrência direta da opção que se faz sobre a urgência de certas matérias, não parece sensato deixar de estender o controle dos gastos públicos desde o momento inicial de tramitação legislativa do projeto de lei orçamentária, nem impedir que o Tribunal de Contas participe do debate público que precede a sua aprovação e estabeleça um salutar debate sobre o destino dado aos valores que são arrecadados dos contribuintes. O Judiciário só pode interferir na distribuição de receitas em alguns casos, exatamente porque não lhe cabe, em tese, influir na fixação das despesas públicas, atividade tipicamente política, mas tanto quanto o Tribunal de Contas, pode provocar o controle social.

As leis orçamentárias são o mais apropriado exemplo de normas instituidoras de políticas públicas - nesse sentido, o art. $2^{\circ}$ da Lei n. 4.320/64, que se refere a "política econômico-financeira" e a "programa de trabalho do Governo", e o art. 165 da Constituição Federal, que atribui ao plano plurianual "as diretrizes, objetivos e metas da administração federal para as despesas de capital e outras delas decorrentes e para as relativas a programas de duração continuada". Ora, se os tipos de orçamento são a forma inevitável de dar início à concreção de políticas públicas, é de se reconhecer que o Plano Plurianual (PPA), a Lei de Diretrizes Orçamentárias (LDO) e a Lei Orçamentária Anual (LOA), que é a cristalização do PPA e da LDO, são normas-objetivo e não admitem a livre partilha de seus valores entre o Congresso e a Presidência da República, nem a discricionariedade sobre a disposição dos recursos públicos arrecadados. A respeito, podese invocar a lúcida observação de Eros Grau, para quem "a existência de uma normaobjetivo no bojo de uma parcela do ordenamento jurídico vincula o intérprete na interpretação de suas normas de conduta e de organização, de modo que não poderá ser tida como aceitável hermenêutica que não seja estritamente coerente com a realização dos fins nela inscritos". 141

Uma Constituição dirigente como a nossa não procura só garantir o presente, mas programar o futuro. A interdependência entre Estado e sociedade promove a necessária legitimação das opções políticas que comandam a distribuição de verbas do orçamento. Seria insensato e inócuo admitir que as leis que instituem as políticas públicas são normasobjetivo se não atribuíssemos igual hierarquia às normas que realmente possibilitam, na prática, efetivar as dotações necessárias aos planos de ação governamental, expressos nas leis orçamentárias em termos físicos e financeiros. Se elas não forem consideradas mais

141 GRAU, Eros Roberto. Notas sobre a noção de norma-objetivo, p. 148-149. 
que simples autorizações, incapazes de vincular o intérprete na execução do orçamento, todo o processo de discussão no Parlamento não terá sido mais que o produto de exaustivas sessões de muitos rinocerontes e poucos Bérengers. ${ }^{142}$

Ressalta-se também que o controle social deve permitir a inclusão do povo para manifestar-se sobre a suficiência dos investimentos e se uma continuidade mínima dos programas de longo prazo está sendo observada. Os dois atores envolvidos na disputa, o Legislativo e o Executivo, podem estar politicamente comprometidos com ideologias e interesses partidários para decidir, com serenidade e isenção, como atender o interesse público e para serem suficientemente éticos na repartição de reservas que são, inegavelmente, moeda de troca para garantia de posições majoritárias no Congresso e resposta efetiva aos anseios egoístas de minorias que lhes dão sustentação política. $\mathrm{O}$ controle efetivo do Poder Público e a garantia real de direitos e liberdades dos administrados dependem, em verdade, desse procedimento. A proposta apresentada nesta tese não é a única via necessária a alcançar esse desiderato, mas, certamente, deve ser o primeiro passo a ser dado. Um exemplo irá aclarar o que se quer dizer: a pressão exercida pelos poucos eleitores sobre os seus mandatários no Congresso seria suficiente para legitimar a extinção da CPMF e a conseqüente crise política que o ato parlamentar gerou? Até que ponto a aparente submissão à democracia foi observada? Até que ponto a pressão exercida pelos cidadãos foi representativa da vontade popular? Pode-se ir mais longe, ainda: se a questão tivesse sido decidida em um plebiscito, a democracia teria sido observada? Imagine-se, para dar um exemplo recente, que o povo venezuelano houvesse decidido apoiar as mudanças nada constitucionais de Hugo Chávez. Esse resultado seria democrático? Maioria absoluta é sempre garantia de democracia?

\subsection{DEMOCRACIA INCLUSIVA E RESPONSIVA. CONTESTABILIDADE E DEMOCRACIA}

Robert Post responde a questão, por nós feita em relação à política Venezuelana, formulando um hipotético caso: o Estado $\mathrm{X}$, no qual os cidadãos possuem terminais domésticos de computador para manifestar, diariamente, a sua opinião pessoal sobre os assuntos públicos mais relevantes e, interativamente, receber todas as informações que creiam ser necessárias para decidir com correção, seria um Estado democrático? Esse

142 O rinoceronte, peça de Ionesco, descreve a luta de Bérenger contra os rinocerontes, que se opõem não só à sensibilidade, mas também à razão. 
Estado estaria, na verdade, computando os votos diariamente dados em consultas e plebiscitos, a ponto de quase igualar a democracia direta da Ágora grega, porém, com uma diferença substancial: nesse Estado X não há discurso político, nem meios para que cada eleitor possa confrontar a sua própria opinião com o pensamento dos outros cidadãos. Ainda assim, poderíamos considerar o Estado X comprometido com a autodeterminação?

O mestre da Yale Law School sustenta que os valores da democracia são efetivamente observados se houver uma ininterrupta mediação entre autodeterminação individual do cidadão e autodeterminação coletiva, ou seja, se cada um dos eleitores puder reconhecer na vontade geral a potencialidade de sua própria vontade:

Certamente não é plausível dizer que pode existir uma completa identidade entre
a vontade individual dos cidadãos e a vontade geral do Estado democrático,
como se pode imaginar que Rousseau tenha dito. É suficiente que os cidadãos
possam reconhecer naquela vontade geral a potencialidade de sua própria
autoria. Quando isto ocorre, a tomada de decisão coletiva é democrática porque é
experimentada como autodeterminação. Mas quando os cidadãos se sentem
alheios à vontade geral, ou ao processo através do qual essa vontade geral é
criada, votar sobre quaisquer assuntos é apenas um mecanismo para a tomada de
decisões, um mecanismo que pode facilmente se tornar opressivo e
antidemocrático. (...) É esta a teoria da Primeira Emenda americana, que se
baseia na idéia de que os cidadãos são livres para participar na formação da
opinião pública, e se as decisões do Estado são tomadas em correspondência à
opinião pública, os cidadãos serão capazes de sentir o governo como seu, mesmo
que tenham visões divergentes ou discordem de alguma outra coisa. É por isso
que a Primeira Emenda, que é antimajoritária, é, mesmo assim, considerada "a
guardiã de nossa democracia". ${ }^{143}$

Sucede que essa interação, esse sopesamento entre vontade individual e vontade geral, pressupõe o exercício da cidadania que cada eleitor assume, de maneira constante, nos destinos da coisa pública. Essa interação não se dá, absolutamente, com a realização de consultas e plebiscitos a cada dez anos ou com a realização de eleições livres. Ela só pode acontecer com a lenta e continuada participação popular, capaz de moldar, a longo prazo, uma consciência cívica responsável. Como se vê, o que Post propõe nada mais é do que legitimação do poder, do Estado e do Direito:

Na democracia moderna, por consequiência, os cidadãos são livres para se envolverem no discurso público de forma a fazer com que o Estado responda às suas idéias e valores, na expectativa de que, mesmo se o Estado atuar de forma inconsistente com aquelas idéias e valores, tais cidadãos possam, não obstante, manter com ele uma identificação. ${ }^{144}$

143 POST, Robert C. Democracia e igualdade, p. 6-7.

144 POST, Robert C. Democracia e igualdade, p. 7. 
Essa idéia, assim como a Primeira Emenda, é antimajoritária, não antidemocrática, haja vista que objetiva proteger determinados valores nucleares contra paixões majoritárias e proporciona um espaço de participação garantida a grupos minoritários. Note-se que as eleições periódicas legitimam as escolhas dos representantes do povo, mas não a atuação dos parlamentares durante os quatro anos de mandato. Isto seria, em termos, a mesma coisa que instituirmos procuradores com plenos poderes para gerir nossas vidas pessoais e só exigirmos prestações de contas no final do mandato. Pior, nos nossos negócios particulares sempre podemos, a qualquer tempo, cassar o mandato do mandatário suspeito, sem maiores explicações, mas na vida pública não podemos fazer mais do que lamentar a escolha e tentar eleger, na próxima eleição, representantes mais competentes. Em nenhum momento, durante quatro anos, reconhecemos na vontade geral a potencialidade de nossa própria vontade. Ela está presente para legitimar todos os empossados, até mesmo aqueles que consideramos indignos, mas essa repulsa é suplantada pela dignidade mútua das vontades autônomas.

É isso que se dá na nossa vida pública, especialmente no momento mais crucial, em que os parcos recursos da poupança popular arrecadados com tributos imoderados são literalmente atirados ao lixo, ainda na fase de discussão do plano plurianual e dos projetos orçamentários. Nesse momento, o povo desconhece o destino dado à quase metade de seus ganhos. Somente depois, com a edição de uma lei formal, que não é lida porque excessivamente técnica, a sociedade é informada de seu teor. Ressalta-se que, apesar de ser uma "lei", a peça pode ser livremente manipulada pelo Presidente da República. É nesse instante de descontrole que políticas públicas nascem, abortam ou têm continuidade. O controle posterior, seja ele qual for, não pode mais que justificar ou criticar os bilhões investidos em governos anteriores. Obras indispensáveis de programas continuados são paralisadas ou sepultadas, e inúteis projetos megalomaníacos são implantados.

O Ministro Gilmar Mendes, no exercício da presidência do Supremo Tribunal Federal, abordando o tema do orçamento e sua alteração injustificada por Medida Provisória, afirmou que

É como se estivéssemos numa roleta russa com todas as balas do revólver (...) Estamos em meio a uma crise econômica mundial grave (...) Como não lançar mão da MP nessa situação? Mesmo que houvesse mecanismos alternativos de decisão é justificável a MP num contexto desses. 
Mas estávamos fazendo praticamente todo o Orçamento com medida provisória. É justificável isso? Não. O Congresso pode reagir? Claro, até mesmo devolvendo as MPs ao presidente, rejeitando, não deixando que elas tenham curso. ${ }^{145}$

Não se desconhece, em termos de representatividade democrática, a força do "teorema da impossibilidade" de Kenneth Arrow, Prêmio Nobel de Economia de 1972, segundo o qual o coletivo tem regras próprias de funcionamento e uma racionalidade diferentes das individuais. Arrow definiu, primeiro, alguns postulados matemáticos que caracterizam o comportamento racional de um indivíduo e depois colocou vários indivíduos juntos para ver se o grupo também seguiria o mesmo comportamento. Descobriu-se que é impossível prever o resultado, pois a soma das racionalidades individuais não determina uma racionalidade coletiva. Essa descoberta colocou para muitos - como William H. Riker, que via na instabilidade da regra majoritária uma desautorização para construir proposições de engenharia política que correspondem a formatos populistas ou de democracia direta - a impossibilidade de se encontrar racionalidade em decisões coletivas. Daí a aparente inutilidade de encontrar uma racionalidade na vontade popular. Isso fez com que o sistema da representatividade eleitoral tradicional ganhasse fôlego em relação à legitimidade dos atos de governo e mesmo de atos legislativos. Alegou-se que o maior perigo do governo pelo povo é sustentar que a vontade popular não pode errar e que a crença na perfeita razão da maioria é uma porta aberta à tirania.

Parece-nos que a questão deve ser analisada cum grano salis. Henry S. Richardson, ${ }^{146}$ enfrentando o tema, assevera que a vontade popular não é algo infalível a ser descoberto, mas, nessa busca, os procedimentos democráticos para tentar descobri-la são os meios necessários para visualizar o bem público (na acepção de Aristóteles, segundo a qual o objeto da escolha é o bem ou o bem aparente). Essa busca, exatamente por incluir o cidadão em seu procedimento, alcança uma legitimação popular essencial para o sucesso de qualquer programa político, econômico e social. Nesse sentido, Ulrich K. Preub, ${ }^{147}$ professor de Direito Constitucional e de Ciências Políticas na Universidade Livre de Berlim, afirma que "há uma forma de soberania em que o elemento do poder coercitivo recua mais e mais e que poderíamos chamar de soberania em virtude de reconhecimento. A

145 O Estado de S. Paulo, p. A6, 4 nov. 2008.

146 RICHARDSON, Henry S. Em defesa de uma democracia qualificada, p. 183.

147 PREUB, Ulrich K. Os elementos normativos da soberania. In: MERLE, Jean-Christophe; MOREIRA, Luiz (Org.). Direito e legitimidade, p. 171. 
sua função central não é obrigar a obedecer, mas legitimar o domínio até o ponto ideal, em que domínio nada mais é que autodeterminação”.

De qualquer maneira, a questão fica cabalmente respondida por Henry Richardson, quando, apoiado em Bruce Akerman ("We the People"), enfatiza que não se pode confundir Congresso com povo reunido e, se o fizermos,

\begin{abstract}
ele agirá de modo a negar sua retórica democrática. (...) Consoante o dualismo, não há nenhuma instituição governamental que se possa arvorar em falar pelo povo: "nenhuma instituição de política normal pode transubstanciar-se, a si própria, no povo dos Estados Unidos". (...) O importante é que os indivíduos sejam respeitados como participantes autônomos e iguais do processo deliberativo. ${ }^{148}$
\end{abstract}

Em resumo, "o ideal político do governo pelo povo ou a idéia de que a lei deverá expressar a vontade do povo, que participa ativamente da formação de seu governo através do voto ou de outro modo, reside no ideal liberal, segundo o qual o processo político deve respeitar os cidadãos como pessoas autônomas livres e iguais"149.

Acreditamos que o "teorema da impossibilidade" não se aplica ao regime democrático para invalidar a fórmula consagrada de "governo do povo pelo povo". Dar razão a Arrow seria persistir na superada idéia do dualismo entre Estado e sociedade. Acreditamos que o orçamento, fonte de todas as políticas públicas, não deve ser tomado como simples ato administrativo (lei formal), mas como norma-objetivo, de modo a impedir a livre manipulação de suas verbas. Não há nenhuma ocasião em que o Estado necessite tanto da legitimação popular como na discussão dos projetos das leis orçamentárias. Se esse procedimento for admitido, permitindo a livre participação da sociedade nesse momento crucial, os programas e políticas governamentais poderão contar com a importante chancela de confiança a plataformas políticas prometidas, mas que só adquirem densidade na concreção dos projetos orçamentários. Ademais, é de se presumir que a legitimação popular apresenta-se essencial para o sucesso de qualquer programa político, econômico ou social.

A democracia, da forma supra-apresentada, está inevitavelmente vinculada ao consentimento popular. No entanto, como é comumente entendida, depende, quase exclusivamente, de eleições livres e gerais. O povo só poderá manifestar-se, de maneira efetiva, nas eleições subseqüentes. Esse procedimento pode legitimar a posse dos candidatos eleitos, mas não todos os atos que praticarem até o final do mandato. O grande

148 RICHARDSON, Henry S. Em defesa de uma democracia qualificada, p. 190-193.

149 RICHARDSON, Henry S. Em defesa de uma democracia qualificada, p. 193. 
prestígio que o mundo intelectual confere a Philip Pettit, chairman de Ciência Política na Universidade de Princeton, dá a ele autoridade suficiente para sustentar a sua tese de democracia e contestabilidade, que realmente põe uma pá de cal sobre o assunto:

\begin{abstract}
Exigir que as decisões públicas sejam contestáveis, sobretudo que as contestações possam partir de qualquer segmento da sociedade, é insistir em que a tomada de decisão satisfaça um determinado perfil democrático. (...) pode-se entender a democracia como parte de um modelo primariamente mais contestatório que consensual. Nesse modelo, um governo será democrático, ou seja, representará uma forma de mando controlado pelo povo, na medida em que este povo, individual e coletivamente, possa usufruir permanentemente o direito de contestação perante as decisões do governo. ${ }^{150}$
\end{abstract}

É interessante notar como as opiniões de Pettit possuem pontos de acentuada tangência com os ensinamentos de Post, Henry Richardson e Ulrich Preub. Todos eles defendem uma participação popular atuante, possível, mas execram o consentimento implícito, que seria evidenciado pela ausência de protesto. Democracia não é direito de protestar, é permitir à população, não somente aos cidadãos, influir, positivamente, na forma como o governo e o Parlamento dão concreção aos planos e projetos financiados pela poupança que lhe foi resgatada. Não nos parece ser demasia permitir àquele que financia inteirar-se dos planos econômicos de seus procuradores, com possibilidade efetiva de se opor a tudo o que considerar desnecessário, imoral, e ineficaz. Silêncio não é concordância tácita, pode muito bem ser desesperança, resignação. Ele só será aprovação tácita se sentir na vontade geral dominante a potencialidade de seu próprio querer (Post).

A prévia provocação elucidativa do Tribunal de Contas, cujas funções específicas seriam tornar públicas as questões relevantes, esclarecendo-as, e emitir alertas e recomendações para análise de todos os atores envolvidos na discussão, tornaria viável o efetivo direito de contestação que a sociedade possui. Não há outra forma de abreviar o abismo existente entre Estado e sociedade.

Enfatiza-se que manter a legitimidade dos atos do governo e do Parlamento fundada somente nas eleições periódicas representa uma clara louvação ao "teorema da impossibilidade" de Arrow, pois, se a soma das racionalidades individuais não garante uma racionalidade coletiva, não se pode negar que esse objetivo pode ser alcançado muito mais facilmente se contar com a participação e concordância de todos.

150 PETTIT, Philip. Democracia e contestabilidade. In: MERLE, Jean-Christophe; MOREIRA, Luiz (Org.). Direito e legitimidade, 2003, p. 371-372. 
Um projeto político e a execução de políticas públicas em um Estado responsivo, conduzido, na maneira do possível, por concepções integradas, não impostas de cima para baixo, envolve, para além das convicções pessoais dos congressistas e do Presidente da República, o sopro vital daquele que suporta todas as conseqüências de suas experiências: a população, como um todo. A complexidade normativa estatal e as experiências dos tecnocratas não possuem densidade maior que a fome, a doença, a desesperança, a indignidade e a revolta suportadas pelo homem real, que é o mesmo que sustenta os atos perdulários do governo e as liberalidades desprovidas de interesse público.

\subsection{FUNÇÃo POLÍtica E PROGRAMÁtica do ORÇAMENTO PÚblico. LEI DE NATUREZA HÍBRIDA: FORMAL E MATERIAL. PLANEJAMENTO ESTATAL E ORÇAMENTO}

O orçamento desempenha, com a complexidade dos problemas socioeconômicos da atualidade, cada vez mais funções, conforme o ângulo que se estiver analisando. Predominava, há até bem pouco tempo, o aspecto financeiro, simplesmente financeiro, de ordenamento de despesas e receitas. Nesse prisma, seria natural entender a lei orçamentária como uma típica lei formal. Esgotava-se, ela, em sua aplicação. No entanto, por detrás dos números, funções muito mais importantes podem, eventualmente, ser encontradas. Assim, a função política, a função reguladora e a função programática são os principais aspectos do orçamento. Não podem elas, por absoluta impropriedade dos conceitos, ser conciliadas com a idéia de lei formal. As leis orçamentárias, a nosso ver, são híbridas e não podem ajustar-se com exclusividade nem em seu caráter formal, nem na abstração de sua materialidade.

Essa visão das normas orçamentárias é essencial para entender como se opera o seu controle. Em sua porção formal, os órgãos de controle têm bem pouco a fazer além de usar os instrumentos de controle próprios do ato administrativo. Evidentemente, não há controle abstrato sobre lei de efeitos concretos. O mesmo não acontece com o seu lado material, que, por não esgotar seus efeitos em um único ato, não pode estar em contraste com a Constituição.

Em sua função programática, a lei orçamentária é lei abstrata porque há, sempre que necessário, uma renovação da hipótese de incidência da norma e das suas consequiências. Embora ela tenha destinatário certo, que é o executor do orçamento, os seus efeitos, por não se esgotarem em um ato ou fato, possuem a abstração da lei material. 
Relembrando Kelsen, ${ }^{151}$ o que caracteriza ser a norma abstrata ou concreta não é o número de destinatários: se o pai ordenar a todos os seus filhos para ir à missa hoje, tem-se ato concreto, mas se um pai disser a seu filho único que ele está obrigado a ir à missa todos os domingos, estará estabelecendo uma norma geral. No primeiro caso, a despeito da pluralidade de sujeitos, a norma é concreta; no outro, embora a ordem seja dirigida a um único filho, a norma é abstrata, pois rege um número indeterminado de condutas (a ordem se protrai no tempo).

A lei de orçamento, examinada em sua função programática, ao estabelecer as fundações de políticas públicas que terão continuidade por muito tempo, como normaobjetivo que é, deverá limitar a discricionariedade política tanto do executor do orçamento, que não poderá dispor de verbas alocadas com a mesma facilidade, mesmo com autorização legislativa, quanto dos governos posteriores. Assim, o Parlamento poderá estar atado, na medida do razoável, por um prazo bastante longo, que se estenderá às futuras legislaturas e impedirá o remanejamento e a utilização de recursos que impliquem a ocorrência de prejuízo significativo ou a paralisação dessas políticas. É possível dizer, em casos semelhantes a esses, que, por trás dos números que instituem as políticas, há um dispositivo dotado de normatividade, que continuará a restringir o juízo político dos administradores do futuro.

Salvo melhor juízo, trata-se, na espécie, de regra-matriz. Fortes na lição de Bobbio, esses dispositivos são "normas de estrutura", pois seguirão regulando a produção de outras normas e comandando a produção de inúmeros outros dispositivos, estes sim, normas concretas. Como ensina Paulo Dourado Gusmão, “a norma jurídica é geral e abstrata, não por regular caso singular, mas por estabelecer princípio aplicável a vários casos, que podem ou não ocorrer". 152

Pressupondo correta a natureza híbrida do orçamento, podemos dizer que ele é, ao mesmo tempo, mera autorização e - ressalvadas as excepcionalidades - rigoroso modelo impositivo. Veja-se que essa constatação não altera o fato de que o orçamento dificilmente poderia criar direitos subjetivos para terceiros, porque as normas-objetivo, em razão de determinar resultados e fins relevantes para o Direito, comandam a produção de outras normas, de conduta e organização. Como instrumento de governo, passa a ser dinamizado tendo em vista a implementação de políticas públicas. A "definição dos fins de tais

151 KELSEN, Hans. Teoria geral das normas. Tradução de José Florentino Duarte. Porto Alegre: Fabris, 1986, p. 10-11.

152 GUSMÃO, Paulo Dourado. Introdução ao estudo do direito. 16. ed. Rio de Janeiro: Forense, 1993, p. 87. 
políticas é enunciada, precisamente, em textos normativos que consubstanciam normasobjetivo e que, mercê disso, passam a determinar os processos de interpretação do Direito". 153

O interesse envolvido, exatamente por isso, transcende, de maneira notável, direitos subjetivos que possam ser eventualmente violados. Nesse aspecto, a limitação atinge até um dos mais importantes aspectos políticos do orçamento, que é o de assegurar os gastos necessários aos três Poderes para que possam cumprir suas finalidades. É que as políticas públicas implementadas pelas outras esferas do poder também não podem ficar à mercê da impontualidade de repasses, no caso de uma eventual não-aprovação do orçamento na época aprazada, ou em face da constatação de que uma das estruturas de Poder possui, na prática, uma certa discricionariedade sobre a realização das despesas engendradas pelos demais Poderes.

Em relação à vinculação do Poder Público ao planejamento que efetuar, verifica-se que ele é uma atividade obrigatória para o Estado e determinante para o setor público, ${ }^{154}$ desse modo, está submetido ao princípio da legalidade. Demais disso, a Constituição determina $^{155}$ que os planos e programas nacionais, regionais e setoriais serão elaborados em consonância com o plano plurianual, o que também demonstra a natureza material das leis orçamentárias, de vez que a compatibilidade entre os tipos de orçamento é recíproca.

\subsection{CONTROLE SOCIAL DO ORÇAMENTO. REPRESENTATIVIDADE E PARTICIPAÇÃO DAS MINORIAS NO PROCESSO DAS NORMAS ORÇAMENTÁRIAS}

Regis Fernandes de Oliveira, ao tratar do controle social do orçamento, ensina que:

153 GRAU, Eros Roberto. Ensaio e discurso sobre a interpretação/aplicação do direito, p. 128.

154 Constituição Federal, art. 174: "Como agente normativo e regulador da atividade econômica, o Estado exercerá, na forma da lei, as funções de fiscalização, incentivo e planejamento, sendo este determinante para o setor público e indicativo para o setor privado".

155 Constituição Federal, art. 165: "Leis de iniciativa do Poder Executivo estabelecerão:

I - o plano plurianual;

II - as diretrizes orçamentárias;

III - os orçamentos anuais.

$\S 1^{\circ}$ A lei que instituir o plano plurianual estabelecerá, de forma regionalizada, as diretrizes, objetivos e metas da administração pública federal para as despesas de capital e outras delas decorrentes e para as relativas aos programas de duração continuada.

(...)

$\S 4^{\circ}$ Os planos e programas nacionais, regionais e setoriais previstos nesta Constituição serão elaborados em consonância com o plano plurianual e apreciados pelo Congresso Nacional". 
O controle do gasto público efetuado pelos três poderes e demais entes e empresas sujeitas à disciplina orçamentária não dispensa a participação social. As estruturas burocráticas são insuficientes para efetuar um adequado e correto controle do gasto público. Da mesma forma se pode dizer da arrecadação da receita.

Sem erro pode-se afirmar que a democracia moderna não se sustenta na teoria montesquiana de fiscalização recíproca entre os poderes. Com certeza, aceita-se a premissa de que todo aquele que detém o poder tende a dele abusar. É experiência eterna, dizia o grande autor. Logo, não só se impõe que o poder controle o poder, mas que o povo o controle, também. ${ }^{156}$

Foi exatamente essa observação que inspirou este trabalho: a fiscalização recíproca entre os Poderes é insuficiente, somente o povo completa o quadro exposto por Montesquieu. Nesse sentido, é preciso reconhecer que não há representatividade densa e eficaz da maioria absoluta da população no Congresso Nacional. A, hoje, Ministra Carmen Lúcia Antunes Rocha afirmou, referindo-se ao sentido de igualdade constitucional e maiorias numéricas, que certas "minorias" constituem, em verdade, maioria numérica, mas destituídas de poder econômico e político, e "poder" é a capacidade de fazer com que os outros respeitem e considerem a sua vontade. Enquanto liberdade significa cada um satisfazer a sua vontade, a autoridade, ou o poder, é fazer com que os outros respeitem a minha vontade.

\begin{abstract}
Não se aspira uma igualdade que frustre e desbaste as desigualdades que semeiam a riqueza humana da sociedade plural, nem se deseja uma desigualdade tão grande e injusta que impeça o homem de ser digno em sua existência e feliz em seu destino. $\mathrm{O}$ que se quer é a igualdade jurídica que embase a realização de todas as desigualdades humanas e as faça suprimento ético de valores poéticos que o homem possa desenvolver. As desigualdades naturais são saudáveis, como são doentes aquelas sociais e econômicas, que não deixam alternativas de caminhos singulares a cada ser humano único (...) Igualdade constitucional é mais que uma expressão de Direito; é um modo justo de viver em sociedade. Por isso é princípio posto como pilar de sustentação e estrela de direção interpretativa das normas jurídicas que compõem o sistema jurídico fundamental. ${ }^{157}$
\end{abstract}

De fato, não é possível reconhecer a vontade da maioria dos representantes dos eleitores como vontade da população. A Ministra referia-se, em sua fala, às mulheres e aos pobres, que são evidentes minorias nos círculos de poder e influência política, mas que, agregadas a outras minorias, constituem maioria expressiva. Exatamente por isso o Professor Regis não admite a ausência do povo no controle do poder e critica, asperamente, o controle social, apenas retórico, da arrecadação da receita e do gasto público, "para constar que existe". Vale a pena transcrever a lição:

156 OLIVEIRA, Regis Fernandes de. Curso de direito financeiro. São Paulo: RT, 2006, p. 296-297.

157 SILVA, José Afonso da. Curso de direito constitucional positivo, p. 208-209. 
O importante é encontrar mecanismos que possam dar legitimidade à participação popular. No orçamento participativo, por exemplo, em que se torna obrigatória a consulta à população sobre suas necessidades, deve haver instrumentos que possam permitir a livre manifestação da vontade. (...) Certos locais que são dominados por líderes carismáticos ou que manipulam o povo, prestando-lhes serviços comunitários, bancados por políticos, distorcem a vontade popular. Nem se diga que o líder pode compor determinados conselhos ou grupos de debate e decisão que possam ser coordenados por cabos eleitorais predispostos a chegar a determinada proposta. A ilusão de se chegar a determinados valores fica imposta. A vontade fica maquiada pela falsa vontade composta por interesses escusos dominantes. Dir-se-á que democracia é a prevalência da vontade da maioria. Nem sempre, no entanto. Apenas há a prevalência da vontade efetiva da maioria quando esta respeita a minoria. (...) Quando, no entanto, se percebe que a discussão livre das idéias é mera formalidade para que se chegue rapidamente ao resultado final, há farsa. ${ }^{158}$

A longa citação se impõe. Ela se afina com o ensinamento de Post e ao quanto já foi dito no item 8.1 deste capítulo. Os valores da democracia só são efetivamente observados se houver uma ininterrupta mediação entre autodeterminação individual do cidadão e autodeterminação coletiva, ou seja, se cada um dos eleitores puder reconhecer na vontade geral a potencialidade de sua própria vontade. De uma maneira mais ampla, se não estivermos circunscritos ao processo eleitoral, pode-se dizer que a democracia completa-se no reconhecimento, na vontade geral, da potencialidade da vontade do indivíduo, que, por sua vez, só acontece quando cada pessoa tiver consciência de suas possibilidades de se opor, efetivamente, às decisões que lhe dizem respeito. Esse, aliás, é o espírito que animou a Primeira Emenda nos Estados Unidos: não se pode confundir maioria com democracia. Ela se completa na decisão da maioria se as minorias puderem opor às teses majoritárias, suas antíteses; às alegações, contradições; e às convicções prevalecentes, suas crenças e posições pessoais.

Em matéria de controle social, é costume dizer que o Poder Público não está sujeito somente à lei, mas ao Direito. Isso requer que também os controles exercidos sobre qualquer atividade pública não fiquem restritos à legalidade estrita, de modo a ajustar-se à mesma sintonia do interesse público, que, por ser o critério buscado pelo Poder Público, obriga o controlador, seja ele judicial, político ou social, a trilhar o mesmo caminho. Se isso não for feito, a legalidade estará formalmente preservada, mas o interesse público será ditado, invariavelmente, pelo Estado, segundo seus próprios standards. Por isso, os sistemas de controle, especialmente o controle social e o exercido pelos órgãos de controle, não devem obedecer a fórmulas rígidas de um formalismo excessivo e ineficaz.

158 OLIVEIRA, Regis Fernandes de. Curso de direito financeiro, p. 297. 
A participação da sociedade na escolha e na implantação de políticas públicas, em todas as suas fases, dará a ela maioridade e independência na prática da cidadania. A respeito dessa observação, Klaus Offe ensina que os movimentos sociais têm o efeito de politizar a sociedade civil, moldando-a em uma lapidação constante, rumo a uma dependência cada vez menor de regulamentação, controle ou intervenção estatal. ${ }^{159}$ Que ninguém se engane, no entanto, uma vez que as instituições foram democratizadas, mas o Estado não permitiu que a sociedade também se democratizasse. Esta ficou à margem do processo administrativo, já que a oportunidade de eleger os governantes nada significa em termos práticos.

O mote desta tese é o oposto desse isolamento. É o controle social das políticas públicas, eficaz somente se alcançar a própria nascente desses programas: o orçamento. Fazer dos debates das leis orçamentárias uma verdadeira instância de democracia transparente, com a plena participação social, não prescinde do auxílio do Tribunal de Contas, que é o único poder neutral tecnicamente habilitado para, com todas as qualificações que possui, promover o ingresso do povo como novo ator protagonista do processo orçamentário. A busca da independência a que se refere Offe começa, em se tratando de controle do orçamento, com o auxílio da Corte de Contas. Isso não quer dizer que, modernamente, o Judiciário não venha a ocupar lugar de destaque nessa equação. Como é intuitivo, a participação da sociedade, com auxílio do Tribunal de Contas, pode permitir o ingresso do Poder Judiciário para dirimir as questões de Direito que decorrem de pontos controvertidos nas políticas públicas e mesmo no trâmite dos tipos orçamentários.

A Constituição de 1988 não se limitou a fixar os princípios juspolíticos do Estado Democrático de Direito, prescrevendo, de modo repetitivo, como a enfatizar a importância da participação da sociedade na vida pública, inúmeros procedimentos que requerem a sua participação para legitimá-los. Assim, no art. 10 assegurou a participação dos trabalhadores e empregadores nos colegiados dos órgãos públicos quando seus interesses profissionais ou previdenciários forem objeto de discussão e deliberação; no art. 187 determinou que "a política agrícola será planejada e executada na forma da lei, com a participação efetiva do setor de produção, envolvendo produtores e trabalhadores rurais, bem como dos setores de comercialização, de armazenamento e de transportes"; no art. 198, que as ações e serviços públicos de saúde devem ser organizados com a participação da comunidade; no art. 204, II, que as ações governamentais na área da assistência social serão organizadas com a

159 OFFE, Klaus. Apud DAL BOSCO, Maria Goretti. Discricionariedade em políticas públicas, p. 316. 
participação da população na formulação das políticas e no controle das ações em todos os níveis; no art. 205, que a educação será promovida e incentivada com a colaboração da sociedade, e no art. 206, VI, que o ensino público será ministrado com base no princípio da gestão democrática.

Note-se que a "gestão democrática" foi positivada à condição de princípio constitucional expresso. Tanto isso é indiscutível, para ser aplicado a qualquer atividade pública que repercuta diretamente em interesses relevantes da sociedade, que o art. $37, \S$ $3^{\circ}$, com a redação que lhe deu a Emenda n. 19/98, fixou uma norma geral sobre a participação popular em todos os níveis da Administração Pública. Pensamos, assim, que não há como afastar a participação popular do controle das políticas públicas e, em conseqüência, do trâmite das leis orçamentárias, exatamente porque é no orçamento que os fins constitucionais poderão e deverão ocorrer.

\footnotetext{
Art. 37. A administração pública direta e indireta de qualquer dos Poderes da União, dos Estados, do Distrito Federal e dos Municípios obedecerá aos princípios de legalidade, impessoalidade, moralidade, publicidade e eficiência e, também, ao seguinte: (Redação dada pela Emenda Constitucional n. 19, de 1998) (...)

$\S 3^{\circ}$ A lei disciplinará as formas de participação do usuário na administração pública direta e indireta, regulando especialmente:

I - as reclamações relativas à prestação dos serviços públicos em geral, asseguradas a manutenção de serviços de atendimento ao usuário e a avaliação periódica, externa e interna, da qualidade dos serviços;

II - o acesso dos usuários a registros administrativos e a informações sobre atos de governo, observado o disposto no art. $5^{\circ}$, X e XXXIII;

III - a disciplina da representação contra o exercício negligente ou abusivo de cargo, emprego ou função na administração pública.
}

A sociedade ainda não tem acesso a registros e informações sobre atos do governo, nem a lei que iria disciplinar as formas de participação popular foi editada, mas a norma geral fixada é plenamente eficaz. Nem as políticas, nem as leis orçamentárias, que lhes deram densidade, portanto, podem prescindir da legitimação popular. Como a sociedade não tem acesso direto a dados oficiais, essa legitimação só pode concretizar-se com a participação atuante do Tribunal de Contas, auxiliar da sociedade.

\subsection{ORÇAMENTO PARTICIPATIVO}

Regis de Oliveira, na extensa citação feita no item anterior, referiu-se à ilusão de se chegar a determinados valores quando, em verdade, a vontade fica maquiada pela falsa vontade composta por interesses escusos dominantes, completando a farsa que pode 
ocorrer no orçamento participativo. A lição é bastante esclarecedora e dispensa delongas desnecessárias. Entretanto, é interessante fazer referência ao Projeto de Lei Complementar n. 22, de 2007, que propõe alteração no art. $4^{\circ}$ da Lei de Responsabilidade Fiscal, para estabelecer, como norma geral de caráter obrigatório, o mecanismo da participação popular na fase de elaboração das propostas orçamentárias pela União, por estados, Distrito Federal e municípios. O projeto ainda não foi convertido em lei, mas teve parecer favorável do relator e deixou claro que todos concordam ser necessário dotar as leis orçamentárias de algum tipo de legitimação popular. Os argumentos utilizados pelo Professor Regis de Oliveira para considerar a participação popular no orçamento participativo, tal como tem sido imaginado, um processo de fácil manipulação, exige, antes de tudo, a formulação de meios apropriados para captar a sua vontade real. Além disso, a exata crítica que fizemos sobre a necessidade de o controle social alcançar a fonte onde nascem todas as políticas públicas e, por extensão, todos os males que acometem o uso do dinheiro público, foi formulada pelo Deputado Guilherme Campos, que votou pela rejeição do projeto:

\footnotetext{
Não podemos ignorar que nosso modelo orçamentário foi concebido e consagrado no texto constitucional de maneira orgânica, visando a propiciar a necessária integração entre o plano plurianual e a lei orçamentária anual, sendo o programa o elo de ligação entre os instrumentos de planejamento e de alocação de recursos públicos. O conteúdo orçamentário deve, portanto, ser um reflexo objetivo da orientação dada pelo plano plurianual de governo para a alocação dos recursos públicos durante um determinado período de tempo, estabelecido entre nós entre o segundo ano de mandato do governante até o primeiro ano de mandato do sucessor. A consulta popular deveria nascer, pois, na fase de elaboração do plano plurianual e não ser iniciada na fase de discussão das propostas orçamentárias. (grifo nosso)
}

Todos concordam com a absoluta conveniência de conclamar o povo para participar da tramitação dos tipos de orçamento, mas ainda não se conhece a fórmula que possibilitará essa simbiose entre Estado e sociedade. Ainda que haja muitas possibilidades a serem exploradas, parece-nos que, de imediato, isso seria possível com a participação do Tribunal de Contas. Naturalmente, essa participação seria efetivada por meio da pressão popular e do destaque que a discussão receberia por parte da mídia. Essa proposta, a nosso ver, contorna a ineficácia legitimadora das comissões e representações que se propõem a participar do diálogo político.

Vamos, portanto, um pouco além do ensinamento de Regis de Oliveira:

De seu turno, o Legislativo, verdadeira caixa de ressonância dos anseios populares, deve ter sensibilidade para converter em lei aquilo que o povo 
reclama. Não só seus representantes podem e devem participar das discussões preparatórias dos projetos de lei orçamentária, como podem e devem aprofundar as discussões quando do encaminhamento da proposta. No percurso do projeto, até chegar à votação, deve o Legislativo abrir possibilidades para novas discussões e a participação de novos atores sociais. Os que foram excluídos na primeira discussão, isto é, na preparação do anteprojeto das leis orçamentárias, devem ser chamados para a discussão interna no parlamento.

Nada nem ninguém pode ser excluído, se é que se quer lei que reflita os efetivos interesses sociais. $^{160}$

Em tema de orçamento, a contribuição deste trabalho reside no papel que seria desempenhado pelo Tribunal de Contas, como legítimo auxiliar da sociedade. Demais disso, para viabilizar a proposta não é necessária a aprovação de nenhuma medida legislativa, basta o Tribunal assumir o seu importante papel ao lado do povo. A simples politização da sociedade, não importa a velocidade com que isso será feito, já é um passo dado a caminho da plena participação popular na vida pública.

A solução apontada, pelo menos no atual momento histórico, decorre da constatação de que as políticas públicas no Brasil estão em crise e o retrocesso parece inevitável. Na recente crise que envolveu a ANAC, a Presidência da República e o Ministério da Defesa, propostas radicais formuladas no Congresso para retirar a independência das agências reguladoras já demonstram a opção que se quer fazer pelo descarte de tudo que já foi feito para isolar a regulação econômica da política instável dos governos que se sucedem. É preciso encontrar novas fórmulas para controlar o poder das agências, como a participação social, sem o indesejável retorno à discricionariedade governamental. A opção, em verdade, está entre a evolução do sistema de descentralização e controle social e o puro e simples retrocesso.

160 OLIVEIRA, Regis Fernandes de. Curso de direito financeiro, p. 299. 


\title{
CONCLUSÃO: \\ CONTRIBUTO PARA UM CONTROLE SOCIAL EFICAZ
}

A mensagem de Regis de Oliveira, de que não só "o poder controle o poder, mas que o povo o controle”, e uma outra lição, desta vez de José Joaquim Gomes Canotilho, foram determinantes para a eleição desta tese. Respondendo a uma questão formulada por Agostinho Ramalho Marques Neto, o eminente constitucionalista português confidenciou que:

\begin{abstract}
Tive um sobressalto - e agora posso revelá-lo - quando, nesse encontro em que estivemos os dois (o professor Agostinho Ramalho Neto e eu), o JOSÉ EDUARDO FARIA (não sei se o senhor se recorda) desafiou o dirigismo normativo da seguinte forma: "também já andei por aí e verifico que não é através do texto constitucional, não é através das normas que vamos transformar a realidade". De facto, estávamos numa cidade onde fui ver como se discutia o orçamento participativo, onde se levava a sério o "direito que está na rua", onde se construíam outras propostas para dar concretização à Constituição, através de esquemas normativos. Pude verificar depois que a sua análise era uma teoria muito elaborada pela sociologia crítica, com grande relevância e grande apoio no contexto político-social brasileiro. Cumpre lembrar que, estando eu a acreditar no sujeito histórico que era o vosso das "Directas Já" e da Constituição Portuguesa, e vendo depois outros sujeitos que, de outros modos, tentavam dar concretização à idéia de força normativa da Constituição, eu fiquei a vacilar, não propriamente quanto aos sujeitos, mas quanto aos instrumentos do sujeito para realizar a sua vontade e para, de uma forma racional, concretizar o projecto que estava no texto. Começou aqui a minha dúvida acerca de qual era o sujeito. ${ }^{161}$ (grifo nosso)
\end{abstract}

Ambas as observações são realmente perturbadoras. O poder só pode ser controlado eficazmente se a sociedade puder acompanhar e contestar (Philip Pettit) a forma como a contribuição compulsória retirada de sua poupança vai dar concreção aos planos e projetos do Estado. Afinal, democracia e contestabilidade são prismas inseparáveis de uma mesma materialidade. O consentimento implícito representado pela ausência de protesto não está de modo algum pressuposto nas raras ocasiões em que os eleitores acorrem às urnas, nem supre o interativo diálogo que os agentes políticos devem, continuamente, manter com a

${ }^{161}$ CANOTILHO, José Joaquim Gomes. Canotilho e a constituição dirigente, p. 54. 
sociedade. O seu silêncio só pode ser tomado como aprovação tácita se sentir na ação de seus mandatários a potencialidade de seu próprio querer.

Por outro lado, não é mesmo com o texto constitucional ou com qualquer outra norma positivada que vamos transformar a realidade. Foi o povo que deu um basta ao Estado Novo, ao Governo Collor e à ditadura implantada em 1964. Até mesmo a independência do Brasil, a escravatura e a monarquia teriam sobrevida bastante prolongada se não tivessem contado com a mobilização da população inconformada. Tem razão José Eduardo Faria quando observa que nem a Revolução dos Cravos nem as "Diretas Já" decorrem dos fluxos de freios e contrapesos do próprio sistema. É no "Direito Achado na Rua"162 que rupturas e conquistas sociais extremas acontecem. A Constituição aplicada pelas instituições públicas, até mesmo pelo Supremo Tribunal Federal, não seria, por si só, capaz de provocar as dramáticas alterações no curso da história que a participação popular acabou por concretizar. Falta-lhe, sem uma legitimação popular permanente e eficaz, a condição essencial caracterizadora das democracias contestadoras, nas quais é possível reconhecer a coexistência de suas principais vertentes: a liberdade negativa, a liberdade positiva e o reconhecimento de que na decisão coletiva foi respeitada a potencialidade do querer de cada individualidade que compõe o produto da vontade geral.

Não há, pois, como controlar o poder, nem o poder que controla o poder, sem uma efetiva e constante relação de legitimação social dos atos públicos emanados dos poderes institucionalizados. Direito, política, poder normativo, governo, administração e direitos humanos não sobrevivem nem recebem o sopro vital da legitimação sem a fertilização diária do consentimento popular.

Por outro lado, se a inspiração de nossa tese é tributária dos ensinamentos de Regis de Oliveira e de Canotilho, o entendimento de que o estado de exceção permanente, cuja noção é essencial para a proposta formulada, provoca a ineficácia de parte considerável do ordenamento e, conseqüentemente, o surgimento de uma verdadeira anomia deve ser creditado a José Renato Nalini. Foi somente na sua exposição da tridimensionalidade do Direito e do razoável equilíbrio entre fato, valor e norma que pudemos comprovar aquilo que sentíamos intuitivo: o estado de exceção permanente decorre do peso infinitamente maior que o fato pode adquirir em relação aos outros dois elementos que compõem a tridimensionalidade do direito, já que fato, valor e norma precisam permanecer em constante e razoável equilíbrio.

162 FARIA, José Eduardo; CAMPILONGO, Celso. A sociologia jurídica no Brasil. Porto Alegre: Fabris, 1991. 
A tomada de posição sugerida para conhecimento do magistrado representa uma verdadeira reviravolta nas concepções tradicionalmente aceitas para empenho e ocupação do Poder Judiciário. É inegável, no entanto, que as suas incursões neste sítio causaram, a um só tempo, esperança e temor na comunidade jurídica, sempre cautelosa com os atos capazes de tornar imprecisos os limites entre Direito e política, o que equivale a dizer, entre segurança e justiça. Sucede que o mesmo argumento que recusa a legitimação presumida dos atos do Poder Público também contamina a decisão equivocada do juiz de primeira instância com a injusta irreversibilidade do dano. É que o prejudicado pela decisão equivocada não tem o seu direito recomposto pela simples condenação em perdas e danos. O juiz não é mais a "boca da lei", mas também não pode transformar-se no juizlegislador. Com a posição ativista moderada que sugerimos, trazendo os exemplos da Índia, da África do Sul e da Colômbia, manifestamos nossa esperança de adotar uma solução distante dos extremos da passividade do juiz formalista e do revolucionário que nega não só o positivismo mas a própria positividade do Direito.

Ao Tribunal de Contas reservamos lugar mais privilegiado na formação de um controle social eficaz de políticas públicas, por suas próprias competências, auferidas diretamente pela Carta Magna, e por sua posição de poder neutral, altamente especializado na complexa figura de avaliador de políticas públicas e emissor do relatório (fase final do ciclo da auditoria de natureza operacional) divulgado para ampliar o conhecimento da sociedade sobre os resultados das ações estatais analisadas e promover o controle social em seu mais alto grau.

Estamos cientes dos riscos que informações equivocadas ou mal-intencionadas podem produzir e dos efeitos devastadores que a força irracional do povo pode acarretar. Como bem diz a Ministra Cármen Lúcia, "emoção não faz direito, que é razão transformada em escolha jurídica. Quantos Cristos a humanidade já não entregou segundo emoções populares momentâneas?". A jurista conclui seu voto para liberar a pesquisa feita com células-tronco trazendo a profunda lição de Norberto Bobbio, plena de tristeza e decepção com o incompreensível retardamento de medidas que poderiam assegurar a conquista das mais relevantes aspirações do homem:

Indagava Norberto Bobbio se "a história, em si mesma, tem um sentido, a história enquanto sucessão de eventos, tais como são narrados pelos historiadores? A história tem apenas o sentido que nós, em cada ocasião concreta, de acordo com a oportunidade, com nossos desejos e nossas esperanças, atribuímos a ela. E, portanto, não tem um único sentido. ... Concluo com Kant. O progresso para ele não era necessário. Era apenas possível. Ele criticava os 'políticos' por não terem confiança na virtude e na força da 
motivação moral, bem como por viverem repetindo que 'o mundo foi sempre assim como o vemos hoje'.

... Desse modo, retardavam propositalmente os meios que poderiam assegurar o progresso para o melhor. Com relação às grandes aspirações dos homens de boa vontade, já estamos demasiadamente atrasados. Busquemos não aumentar esse atraso com nossa incredulidade, com nossa indolência, com nosso ceticismo. Não temos muito tempo a perder (BOBBIO, Norberto. A era dos direitos. Rio de Janeiro: Campus, 1992, p. 64)". ${ }^{163}$

O alerta de Bobbio aplica-se como perfeição à resistência oposta ao controle social de políticas públicas desde o seu nascimento, quando tomam forma nas leis orçamentárias. A competência concedida ao Executivo para formular seus planos de governo certamente não lhe confere um poder, ao contrário, impõe-lhe um grave dever. Seria inconcebível que esse munus pudesse lhe assegurar uma livre permissão dispor, sem freios, das parcas reservas públicas. $\mathrm{O}$ aval que lhe empresta o Legislativo, bem o sabemos, muitas vezes é emitido mediante liberações de verbas que beneficiam somente as bases eleitorais do congressista, sem atenção às necessidades coletivas de um país continental. Não se pode generalizar a afirmativa de uso de verbas orçamentárias como moeda de troca, mas a experiência tem demonstrado, como no caso da CPI do Orçamento, que trouxe a público as acusações de Roberto Jefferson sobre a existência de um "mensalão" para garantir o apoio de alguns deputados que votariam com o governo, que a acusação não era de todo fantasiosa, mesmo porque o próprio acusador confessou a sua participação no esquema e cassações e renúncias aconteceram.

Em nossas marchas e retrocessos verificamos que mesmo em períodos de maior prosperidade nunca conseguimos sair do estado de exceção permanente em que o país se encontra. Esta tese, como afirmamos, desde seu projeto já denunciava o estado de miserabilidade e pobreza de $50 \%$ da população brasileira e do absoluto desprezo pela vida de crianças e idosos abandonados, sem direito à vida ou à morte dignas. A crise econômica que afeta todos os países, portanto, não inspirou a proposta de uma nova era no controle social de políticas públicas, mas certamente veio corroborar os argumentos que embasavam o trabalho. Ficou claro, então, que algo deveria ser feito. Optamos por uma posição moderada, de não agressão ao sistema instituído para a separação de poderes, mas que, ao mesmo tempo, cria condições mínimas para atrair o mandante originário, o povo, convidando-o a assumir o papel de protagonista no debate que deve ser travado da forma mais plural possível. Alertamos, também, que essa participação nunca aconteceria sem uma atuação ativa, mas responsável, do Poder Judiciário e do Tribunal de Contas. Para

163 STF - Voto da Min. Cármen Lúcia no julgamento que liberou a continuidade das pesquisas com célulastronco embrionárias no Brasil. ADI n. 3.510, j. 29/05/2008. 
ilustrar o trabalho, trouxemos experiências concretas e bem-sucedidas em outros países, que mostram que é possível formar uma cidadania, ainda que essa seja uma condição difícil de alcançar, uma vez que a tarefa pressupõe a formação de uma cultura de participação responsiva.

De qualquer forma, a proposta depende apenas de vontade política, pois não há qualquer empecilho legal que impeça o Judiciário e o Tribunal de Contas de assumir uma posição que privilegie e torne possível o controle social. Em relação ao Tribunal de Contas a opção é muito mais fácil de sustentar, já que decorre do próprio texto da Constituição e das leis referidas no item 7.5. A Lei n. 9.469/97 expressamente confere a órgãos estatais como o Tribunal de Contas o direito de ingressar nos feitos em que o interesse econômico, direta ou indiretamente, estão relacionados com as suas competências técnicas.

Muitos certamente dirão que a tese é utópica, mas que é a utopia senão o ponto de contato entre a vida e o sonho? Teixeira Coelho faz as seguintes observações sobre a utopia:

\begin{abstract}
Mas a imaginação necessária à execução daquilo que deve vir a existir não é a imaginação, digamos, comum, aquela que se alimenta apenas da vontade subjetiva da pessoa e se volta unicamente para seu restrito campo individual, detendo-se exclusivamente para propor coisas como montanhas de ouro. Tem de ser uma imaginação exigente, capaz de prolongar o real na direção do futuro, das possibilidades; capaz de antecipar este futuro enquanto projeção de um presente a partir daquilo que neste existe e é passível de ser transformado. ${ }^{164}$
\end{abstract}

Boaventura de Souza Santos tem ensinamento no mesmo sentido dessa citação:

... o único caminho para pensar o futuro parece ser a utopia. E por utopia entendo a exploração, através da imaginação, de novas possibilidades humanas e novas formas de vontade, e a oposição da imaginação à necessidade do que existe, em nome de algo radicalmente melhor por que vale a pena lutar e a que a humanidade tem direito. ${ }^{165}$

A Constituição Federal garante a todas as pessoas o direito de se informar e de ser informado acerca do que esteja ligado aos seus direitos fundamentais mais relevantes, especialmente aos relacionados com uma vida digna, e de nutrir o direito natural de acreditar no futuro, ter esperança e poder influir no seu próprio destino. Dizer que nada disso é possível porque não há um dispositivo legal regulamentando a forma como a cidadania deve ser construída, e que não está expressamente entre as atribuições do Poder

164 COELHO NETO, José Teixeira. O que é utopia. São Paulo: Brasiliense, 1980, p. 7-8

165 SANTOS, Boaventura de Sousa. A crítica da razão indolente: contra o desperdício da experiência, p. 332 . 
Judiciário e do Tribunal de Contas promover o desenvolvimento de uma cidadania participativa, ou, ainda, que o povo não tem condições intelectuais para opinar sobre a forma como sua poupança é confiscada para fins absolutamente desprezíveis, seria inconstitucional e amoral. A cidadania, a dignidade da pessoa humana e a condição de mandante que é ostentada pelo povo não são meras recomendações, mas fundamentos do Estado Democrático de Direito em que se constituiu a República Federativa do Brasil. Demais disso, se a construção de uma sociedade justa e a erradicação da pobreza e da miserabilidade absoluta são nossos objetivos fundamentais, como dizer ao povo que ele não pode mais que se manifestar nos momentos eleitorais que lhe são previamente determinados? O sujeito do "Diretas já" foi um acidente feliz em uma vida em que ele é tratado como deficiente, incapaz de formular suas convicções acerca dos projetos mirabolantes que irão onerar não só a sua existência como a de seus filhos, ou ele tem o direito de, sempre que entender oportuno, manifestar-se sobre esses temas? Entendemos que o povo não pode ser alijado das decisões que o atingem diretamente.

A medida, em nosso entender, é urgentíssima. Já perdemos tempo demais, alerta Bobbio. É verdade, os paradigmas socioculturais nascem, têm seu apogeu e morrem, mas só percebemos a sua morte muito depois da assunção do paradigma que lhe há de suceder. O tempo intervalar entre paradigmas torna-se um período impreciso que legitima qualquer solução, posto que não se sabe, ainda, da morte do paradigma dominante. No presente em que vivemos, no entanto, a sua morte foi percebida imediatamente, e exatamente por isso a definição do novo paradigma requer consideração imediata. Boaventura Santos nomeou-o como "paradigma de um conhecimento prudente para uma vida decente"166, mas não é necessário batizá-lo, basta reconhecer que ele deverá ocupar imediatamente o lugar do modelo que se extinguiu e que, na constelação das várias ordens jurídicas existentes, o direito estatal, por mais relevante que seja, é apenas uma dentre as órbitas influentes (estatal, supra-estatal, infra-estatal e inter-estatal).

A escassez de recursos, somada ao desperdício inconseqüente de um terço de nossas arrecadações anuais e à prolongada situação emergencial em que vivemos, reclamam efetivas medidas capazes de, pelo menos, amainar os rigores da completa miséria em que sobrevive expressiva parcela de nossa população. Conforme relata a Fundação Getulio Vargas, em reportagem de $O$ Globo, a expressiva redução do número de brasileiros que vivem na miséria absoluta para 18,11\% no ano de 2008 (35,16\% em 1992)

166 SANTOS, Boaventura de Sousa. A crítica da razão indolente: contra o desperdício da experiência, para um novo senso comum. 6. ed. São Paulo: Cortez, 2007, v. 1, p. 16. 
foi intensamente comemorada pelo governo especialmente porque, se tivermos mais uma década de resultados semelhantes, a imagem do Brasil ficará totalmente diferente.

\begin{abstract}
Outro efeito observado em 2007 foi a queda da fatia de miseráveis na população brasileira. Segundo o estudo, a participação no ano passado foi de $18,11 \%$, contra $19,18 \%$ em 2006. A queda, de 5,9\%, fica abaixo da média de $6,7 \%$ observada desde 2001, enquanto a desigualdade da renda domiciliar per capita a uma velocidade $10 \%$ acima do observado na média entre 2001 e 2006.

Neri pondera que os efeitos sobre a miséria não foram tão profundos em 2007 quanto em outros anos da década atual, e acrescenta que o crescimento da renda foi de 2,26\% no ano passado, contra média de 2,5\% desde 2001.

Mesmo assim, o ano de 2007 não foi ruim, embora não tenha sido o espetáculo do crescimento de 2006. Mas se houver dez anos seguidos como 2007, vamos ter ao fim do período um Brasil completamente diferente, e para melhor, do atual afirma. ${ }^{167}$
\end{abstract}

Apesar da melhora evidente, o resultado enfatiza, por si só, a indignidade dos índices. Levando-se em consideração que $18,11 \%$ da população sobrevive em condição miserável, uma vez que para atingir a classe seguinte, a dos pobres, teriam de auferir renda igual ou inferior a meio salário mínimo, o resultado não é motivo para comemorações. Juntos, miseráveis $(18,11 \%)$ e pobres $(24,1 \%)^{168}$, perfazem a incrível soma de mais de $42 \%$ da população. Seria desculpável aguardar uma década para retirar quase metade da população brasileira da vergonhosa posição social que lhes é preservada com o contínuo desperdício de dinheiro público? Apenas para dar uma idéia do valor estatístico da fome, ressalta-se que há 33,6 milhões de pessoas que vivem em situação de extrema miséria.

Parece-nos que esse estado de coisas compõe o quadro de estado de exceção permanente sustentado e dá substância à nossa proposta de um novo controle social realmente eficaz.

Respondendo à questão formulada no início do trabalho, de como será possível libertar o anjo da história e redimir o passado para desacelerar o insano crescimento das catástrofes que se elevam a nossos pés, sustentamos que a melhor solução decorrerá do

167 Disponível em: http://gl.globo.com/Noticiais/Economia_Negocios/0,,MUL766681-9356,00-PESQUISA+ A+FGV+APONTA+COMO+O+ANO+DA+CLASSE+MEDIA.html. Acesso em: 11 jan. 2009.

168 UOL Notícias - 05/08/2008. Disponível em: <http://noticias.uol.com.br/ultnot/2008/08/05/ult23u 2584.jhtm>. Acesso em: 11 nov. 2008.

Pobreza diminui, número de ricos aumenta e classe média cresce, afirmam estudos do Ipea e da FGV

Da Redação* Em São Paulo

Dois estudos divulgados nesta terça-feira (5) mostram mudanças nas classes sociais brasileiras em seis regiões metropolitanas do país: São Paulo, Rio de Janeiro, Belo Horizonte, Porto Alegre, Salvador e Recife. Um levantamento do Ipea (Instituto de Pesquisas Econômicas Avançadas) revela que o número de pessoas pobres - com renda igual ou inferior a meio salário mínimo - caiu de $35 \%$ para $24,1 \%$ no período de 2003 a 2008. Ao analisar a outra ponta da população, o levantamento mostra que o número de indivíduos pertencentes a famílias com renda mensal igual ou superior a 40 salários mínimos (R \$ 16,6 mil) cresceu de $0,8 \%$ para $1 \%$. A expectativa para 2008 é que 11,3 milhões de pessoas estejam na linha da pobreza." 
atendimento de uma série complexa de fatores, mas ela nunca irá ocorrer se não puder contar com a ativa participação da sociedade no controle do Estado. Nenhum poder neutral, nenhuma entidade, por mais qualificada que seja, nenhuma técnica poderá suprir a competência única da sociedade na avaliação crítica das políticas públicas. Enfatiza-se, por último, que o controle social não é a panacéia de todos os males, mas é a única forma de tornar eficaz o conjunto de opções empregadas para o controle interno e externo de políticas públicas. 


\section{REFERÊNCIAS}

ACKERMAN, Bruce. The new separation of powers. Harvard Law Review, n. 113, 2000, p. $634-638$

AGAMBEN, Giorgio. Estado de exceção. 2. ed. São Paulo: Boitempo, 2007.

ARAGÃO, Alexandre Santos de. Agências reguladoras e a evolução do direito administrativo e econômico. Rio de Janeiro: Forense, 2006.

ARAGÃO, Alexandre Santos de. A legitimação democrática das agências reguladoras. In: BINENBOJM, Gustavo (Coord.). Agências reguladoras e democracia. Rio de Janeiro: Lúmen Júris, 2006.

ARAGÃO, Alexandre Santos de. Agências reguladoras e a evolução do direito administrativo econômico. Rio de Janeiro: Forense, 2006.

ARENDT, Hanna. Eichmann em Jerusalém. São Paulo: Schwarcz, 2003.

BASTOS, Celso Ribeiro. Curso de direito constitucional. São Paulo: Saraiva, 1994.

BENJAMIN, Walter. Magia e técnica, arte e política: ensaios sobre literatura e história da cultura. São Paulo: Brasiliense, 1987, v. 1 (Obras Escolhidas).

BIX, Brian. Questões na interpretação jurídica. In: MARMOR, Andrei (Coord.). Direito e interpretação. São Paulo: Martins Fontes, 2000.

BONAVIDES, Paulo. Curso de direito constitucional. São Paulo: Malheiros, 1997.

BONAVIDES, Paulo. Jurisdição constitucional e legitimidade. In: Estudos Avançados, USP, n. 51, p. 127-150, maio/ago. 2004.

BOSCO, Maria Goretti Dal. Discricionariedade em políticas públicas. Curitiba: Juruá, 2007. 
BUCCI, Maria Paula Dallari. Direito administrativo e políticas públicas. São Paulo: Saraiva, 2002.

BUENO, Cássio Scarpinella. Amicus curiae no processo civil brasileiro: um terceiro enigmático. São Paulo: Saraiva, 2006.

BUCCI, Maria Paula Dallari. O conceito de política pública em direito. In: BUCCI, Maria Paula Dallari (Org.). Políticas públicas: reflexões sobre o conceito jurídico. São Paulo: Saraiva, 2006.

CAETANO, Marcello. Manual de direito administrativo. 7. ed. Lisboa: Coimbra Editora, 1965.

CANOTILHO, José Joaquim Gomes. Direito constitucional e teoria da Constituição. Coimbra: Almedina, 1997.

CANOTILHO, José Joaquim Gomes. In: COUTINHO, Jacinto Nelson de Miranda (Org.). Canotilho e a constituição dirigente. 2. ed. Rio de Janeiro: Renovar, 2005.

CARNEIRO, Athos Gusmão. Jurisdição e competência. 13. ed. São Paulo: Saraiva, 2004.

CHEVALIER, Jacques. Public/prive. Paris: Presses Universitaires de France, 1995.

COELHO NETO, José Teixeira. O que é utopia. São Paulo: Brasiliense, 1980.

COMANDUCCI, Paolo. Constitucionalización y teoría del derecho. Conferência pronunciada em 23 de agosto de 2005 na Academia Nacional de Direito e Ciências Sociais de Córdoba, Argentina.

COMPARATO, Fábio Konder. Direito público: estudos e pareceres. São Paulo: Saraiva, 1996.

COMPARATO, Fábio Konder. Ensaio sobre o juízo de constitucionalidade de políticas públicas. Revista dos Tribunais, São Paulo, v. 737, mar. 1997.

COMPARATO, Fábio Konder. Para viver a democracia. São Paulo: Brasiliense, 1989.

CONTI, José Maurício (Org.). Federalismo fiscal. São Paulo: Manole, 2003. 
DELEUZE, Gilles; GUATTARI, Félix. Mil platôs: capitalismo e esquizofrenia. São Paulo: Editora 34, 1996. v. 3.

DERANI, Cristiane. Direito ambiental e econômico. São Paulo: Saraiva, 2008.

FARIA, José Eduardo. Direito e globalização econômica: implicações e perspectivas. São Paulo: Malheiros, 1998.

FARIA, José Eduardo; CAMPILONGO, Celso. A sociologia jurídica no Brasil. Porto Alegre: Fabris, 1991.

FERRAZ JR., Tercio Sampaio. A legitimidade pragmática dos sistemas normativos. In: MERLE, Jean-Christophe; MOREIRA, Luiz (Org.). Direito e legitimidade. São Paulo: Landy, 2003.

FERRAZ JR., Tercio Sampaio. Direito constitucional. São Paulo: Manole, 2007.

FERRAZ JR., Tercio Sampaio. Introdução ao estudo do direito. 4. ed. São Paulo: Atlas, 2003.

FIGUEROA, Alfonso García. Réplica al profesor Thomas da Rosa Bustamante. In: Revista de Direito do Estado, Rio de Janeiro, Renovar, n. 8, p. 147, out./dez. 2007.

GORDILLO, Agustín. La administración paralela. Buenos Aires: Civitas, 1982.

GRAU, Eros Roberto. Ensaio e discurso sobre a interpretação/aplicação do direito. São Paulo: Malheiros, 2005.

GRAU, Eros Roberto. Notas sobre a noção de norma-objetivo. Revista de Direito Público, São Paulo, RT, v. 71, p. 137-152, 1984.

GRAU, Eros Roberto. O direito posto e o direito pressuposto. 3. ed. São Paulo: Malheiros, 2006.

GUSMÃO, Paulo Dourado. Introdução ao estudo do direito. 16. ed. Rio de Janeiro: Forense, 1993. 
HÄBERLE, Peter. Hermenêutica constitucional: a sociedade aberta dos intérpretes da Constituição: contribuição para a interpretação pluralista e 'procedimental' da Constituição. Tradução de Gilmar Ferreira Mendes. Porto Alegre: Fabris, 1997.

HÄBERLE, Peter. Novos horizontes e desafios do constitucionalismo. RDE Revista de Direito do Estado. Rio de Janeiro, Renovar, n. 6, abr./jun. 2007.

HESSE, Konrad. A força normativa da constituição. Tradução de Gilmar Ferreira Mendes. Porto Alegre: Fabris, 1991.

KELSEN, Hans. Teoria geral das normas. Tradução de José Florentino Duarte. Porto Alegre: Fabris, 1986.

KERSTING, Wolfgang. Democracia e educação política. In: MERLE, Jean-Christophe; MOREIRA, Luiz (Org.). Direito e legitimidade. São Paulo: Landy, 2003.

LIMA, Ruy Cirne. Princípios de direito administrativo. 5. ed. São Paulo: Revista dos Tribunais, 1962.

LOEWENSTEIN, Karl. Teoría de la constituición. Barcelona: Ariel, 1983.

LUHMANN, Niklas. Legitimação pelo procedimento. Tradução de Maria da Conceição da Corte-Real. Brasília: Editora UnB, 1980.

MARQUES, Cláudia Lima. Superação das antinomias pelo diálogo das fontes: o modelo brasileiro de coexistência entre o Código de Defesa do Consumidor e o Código Civil de 2002. Revista da Esmese, n. 7, p. 15-54, 2004 - Doutrina.

MASSA-ARZABE, Patrícia Helena. Dimensão jurídica das políticas públicas. In: BUCCI, Maria Paula Dallari (Org.). Políticas públicas: reflexão sobre o conceito jurídico. São Paulo: Saraiva, 2006.

MAXIMILIANO, Carlos. Hermenêutica. Rio de Janeiro: Forense, 2003.

MEDAUAR, Odete. O direito administrativo em evolução. 2. ed. São Paulo: RT, 2003.

MELLO, Celso Antônio Bandeira de. Apontamentos sobre agentes e órgãos públicos. São Paulo: RT, 1984. 
MIRANDA, Jorge. Teoria do estado e da constituição. Rio de Janeiro: Forense, 2002.

MOREIRA NETO, Diogo de Figueiredo. Mutações do direito administrativo. Rio de Janeiro: Renovar, 2000.

MOREIRA NETO, Diogo de Figueiredo. Novos horizontes para o direito administrativo: pelo controle das políticas públicas. Ecos de um congresso: a próxima missão. Revista de Direito do Estado, ano I, n. 4, out./dez. 2006.

MOREIRA NETO, Diogo de Figueiredo. O novo tribunal de contas: órgão protetor dos direitos fundamentais. 2. ed. Belo Horizonte: Fórum, 2004.

MOREIRA, Egon Bockmann; SOARES JR., Lauro Antonio Nogueira. Regulação econômica e democracia: a questão das agências administrativas independentes. In: BINENBOJM, Gustavo (Coord.). Agências reguladoras e democracia. Rio de Janeiro: Lúmen Júris, 2006.

MOREIRA, José Carlos Barbosa. O Poder Judiciário e a efetividade da nova Constituição. Revista Forense 304:151, 1988.

MOREIRA, Vital. Administração autônoma e associações públicas. Coimbra: Editora Coimbra, 1997.

NALINI, José Renato. Constituição e Estado democrático. São Paulo: FTD, 1997.

NEVES, Antonio Castanheira. Metodologia jurídica. Coimbra: Coimbra Editora, 1993.

NUSDEO, Fábio. Curso de economia: introdução ao direito econômico. São Paulo: RT, 1997.

OLIVEIRA, Regis Fernandes de. Ato administrativo. São Paulo: RT, 2007.

OLIVEIRA, Regis Fernandes de. Curso de direito financeiro. São Paulo: RT, 2006.

OLIVEIRA, Regis Fernandes de. Delegação administrativa. São Paulo: RT, 1986.

OLIVEIRA, Regis Fernandes de. Infrações e sanções administrativas. 2. ed. São Paulo: RT, 2005. 
OLIVEIRA, Regis Fernandes de; HORVATH, Estevão. Manual de direito administrativo. São Paulo: RT, 2004.

PETTIT, Philip. Democracia e contestabilidade. In: MERLE, Jean-Christophe; MOREIRA, Luiz (Org.). Direito e legitimidade. São Paulo : Landy, 2003.

PIETRO, Maria Sylvia Zanella Di. Parcerias na administração pública. São Paulo: Atlas, 1999.

POST, Robert C. Democracia e igualdade. RDE - Revista de Direito do Estado, ano 1, n. 3, p. 6-7, jul./set. 2006.

PREUB, Ulrich K. Os elementos normativos da soberania. In: MERLE, Jean-Christophe; MOREIRA, Luiz (Org.). Direito e legitimidade. São Paulo: Landy, 2003.

RAZ, Joseph. Interpretação sem restabelecimento. In: MARMOR, Andrei (Coord.). Direito e interpretação. São Paulo: Martins Fontes, 2000.

RICHARDSON, Henry S. Em defesa de uma democracia qualificada. In: MERLE, JeanChristophe; MOREIRA, Luiz (Org.). Direito e legitimidade. São Paulo: Landy, 2003.

ROCA, Javier Garcia. Separación de poderes y disposiciones del ejecutivo con rango de ley: mayoria, minoria, controles. Cadernos de Direito Constitucional e Ciencia Política, São Paulo, RT, 27/15, 1999.

ROUSSEAU, Jean Jacques. Discurso sobre a origem dos fundamentos da desigualdade entre os homens. São Paulo: Escala, 2006. v. 7 (Coleção Grandes Obras do Pensamento Universal).

SANTOS, Boaventura de Sousa. A crítica da razão indolente: contra o desperdício da experiência, para um novo senso comum. 6. ed. São Paulo: Cortez, 2007. v. 1.

SILVA, José Afonso da. Curso de direito constitucional positivo. 6. ed. São Paulo: RT, 1990.

SORACE, Domenico. Politica - amministrazione. Discrezionalità - autorità. Amministrare, Bologna, ano XIX, n. 1/2, p. 237, abr./ago. 1989. 
TÁCITO, Caio. Evolução histórica do direito administrativo. In: Temas de Direito Público. Rio de Janeiro, Renovar, 1997. v. I.

TORCHIA, Luiza. La scienza del diritto amministrativo. Rivista Trimestrale di Diritto Pubblico, n. 4, p. 1116-1131, 2001.

VITA, Luiz Washington. Momentos decisivos do pensamento filosófico. São Paulo: Melhoramentos, 1964. 